Florida International University FIU Digital Commons

$4-1-2016$

\title{
Hydrogeochemical Modeling of Saltwater Intrusion and Water Supply Augmentation in South Florida
}

Yonas T. Habtemichael

Florida International University, yhabt001@fiu.edu

DOI: $10.25148 /$ etd.FIDC000285

Follow this and additional works at: https://digitalcommons.fiu.edu/etd

Part of the Civil Engineering Commons, Environmental Chemistry Commons, Environmental Engineering Commons, Geochemistry Commons, $\underline{\text { Hydraulic Engineering Commons, Hydrology }}$ Commons, Inorganic Chemistry Commons, Numerical Analysis and Scientific Computing Commons, and the Radiochemistry Commons

\section{Recommended Citation}

Habtemichael, Yonas T., "Hydrogeochemical Modeling of Saltwater Intrusion and Water Supply Augmentation in South Florida" (2016). FIU Electronic Theses and Dissertations. 2438.

https://digitalcommons.fiu.edu/etd/2438 


\title{
FLORIDA INTERNATIONAL UNIVERSITY
}

Miami, Florida

\section{HYDROGEOCHEMICAL MODELING OF SALTWATER INTRUSION AND WATER SUPPLY AUGMENTATION IN SOUTH FLORIDA}

\author{
A dissertation submitted in partial fulfillment of the \\ requirements for the degree of \\ DOCTOR OF PHILOSOPHY \\ in \\ CIVIL ENGINEERING \\ by \\ Yonas Tekleab Habtemichael
}


To: Interim Dean Ranu Jung

College of Engineering and Computing

This dissertation, written by Yonas Tekleab Habtemichael, and entitled Hydrogeochemical Modeling of Saltwater Intrusion and Water Supply Augmentation in South Florida, having been approved in respect to style and intellectual content, is referred to you for judgment.

We have read this dissertation and recommend that it be approved.

$\begin{array}{r}\hline \text { Jeffrey H. Greenfield } \\ \hline \text { Michael C. Sukop } \\ \hline \text { Xia Jin } \\ \hline \text { Hector R. Fuentes, Major Professor }\end{array}$

Date of Defense: April 1, 2016

The dissertation of Yonas Tekleab Habtemichael is approved.

Interim Dean Ranu Jung
College of Engineering and Computing

College of Engineering and Computing

Andrés G. Gil

Vice President for Research and Economic Development and Dean of the University Graduate School

Florida International University, 2016 
(C) Copyright 2016 by Yonas Tekleab Habtemichael

All rights reserved. 


\section{DEDICATION}

I dedicate this dissertation to my parents, my brothers and my sisters. Without their patience, support, and love, the completion of this work would not have been possible. 


\section{ACKNOWLEDGMENTS}

This dissertation would not have been completed without the support of numerous people. I am pleased to express my most sincere gratitude and appreciation to my advisor Dr. Hector R. Fuentes for his guidance, encouragement, valuable suggestions and endless support, all the way from when I first applied to the $\mathrm{PhD}$ program through to the completion of this degree. I also wish to thank the members of my committee, Dr. Michael Sukop, Dr. Jeffrey Greenfield, Dr. Xia Jin and Dr. Walter Tang for their support, thought-provoking suggestions and guidance over the past three years as I moved from an idea to a completed study.

The third chapter was published in Aquatic Geochemistry (Springer) and the final article can be found at http://rd.springer.com/article/10.1007\%2Fs10498-016-9287-1.

I extend my sincere acknowledgments to Dr. June E. Mirecki for providing the cycle test data at the Kissimmee River ASR pilot project. I was privileged to work with an exceptionally comprehensive data set for aquifer storage in Florida.

I would like to thank Florida International University's Graduate School and Department of Civil and Environmental Engineering for providing me financial support through a presidential fellowship and a teaching assistantship, making this research work possible.

Finally, I would like to thank my family and friends for their encouragement and unwavering support throughout my academic endeavor. 


\title{
ABSTRACT OF THE DISSERTATION \\ HYDROGEOCHEMICAL MODELING OF SALTWATER INTRUSION AND \\ WATER SUPPLY AUGMENTATION IN SOUTH FLORIDA
}

by

\author{
Yonas Tekleab Habtemichael \\ Florida International University, 2016 \\ Miami, Florida \\ Professor Hector R. Fuentes, Major Professor
}

The Biscayne Aquifer is a primary source of water supply in Southeast Florida. As a coastal aquifer, it is threatened by saltwater intrusion (SWI) when the natural groundwater flow is altered by over-pumping of groundwater. SWI is detrimental to the quality of fresh groundwater sources, making the water unfit for drinking due to mixing and reactions with aquifer minerals. Increasing water demand and complex environmental issues thus force water utilities in South Florida to sustainably manage saltwater intrusion and develop alternative water supplies (e.g., aquifer storage and recovery, ASR).

The objectives of this study were to develop and use calibrated geochemical models to estimate water quality changes during saline intrusion and during ASR in south Florida. A batch-reaction model of saltwater intrusion was developed and important geochemical reactions were inferred. Additionally, a reactive transport model was developed to assess fate and transport of major ions and trace metals (Fe, As) at the Kissimmee River ASR. Finally, a cost-effective management of saltwater intrusion that involves using abstraction and recharge wells was implemented and optimized for the case of the Biscayne Aquifer. 
Major processes in the SWI areas were found to be mixing and dissolutionprecipitation reactions with calcite and dolomite. Most of the major ions $(\mathrm{Cl}, \mathrm{Na}, \mathrm{K}, \mathrm{Mg}$, $\mathrm{SO}_{4}$ ) behaved conservatively during ASR while $\mathrm{Ca}$ and alkalinity were affected by carbonate reactions and cation exchange. A complex set of reactions involving thermodynamic equilibrium, kinetics and surface complexation reactions was required in the ASR model to simulate observed concentrations of $\mathrm{Fe}$ and As. The saltwater management model aimed at finding optimal locations and flow rates for abstraction and recharge wells. Optimal solutions (i.e., minimum total salt and total cost Pareto front) were produced for the Biscayne Aquifer for scenarios of surface recharge induced by climate change-affected precipitation. In general, abstraction at the maximum rate near the coast and artificial recharge at locations much further inland were found to be optimal. Knowledge developed herein directly supports the understanding of SWI caused by anthropogenic stressors, such as over-pumping and sea level rise, on coastal aquifers. 


\section{TABLE OF CONTENTS}

CHAPTER

PAGE

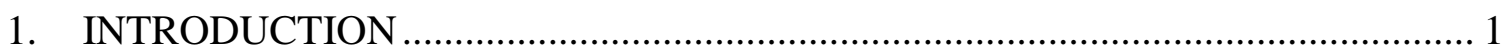

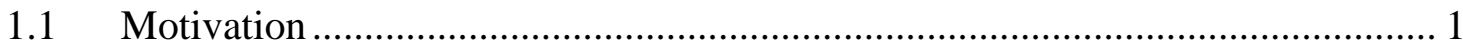

1.2 Saltwater intrusion in Southeast Florida ………................................................ 3

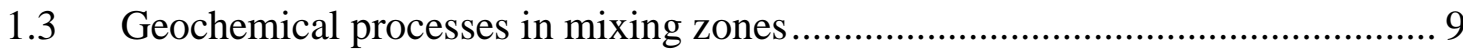

1.4 Hydrogeology and lithology of the Floridan Aquifer System (FAS).................. 15

1.5 Aquifer storage and recovery (ASR) and its challenges ……............................ 17

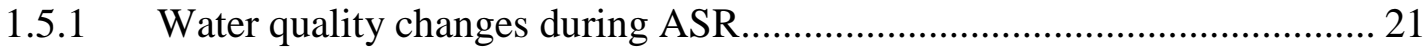

1.5.2 Mechanisms of arsenic mobilization ......................................................... 23

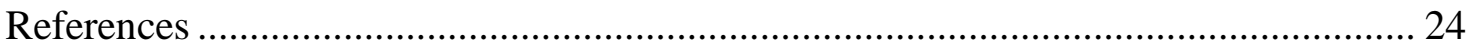

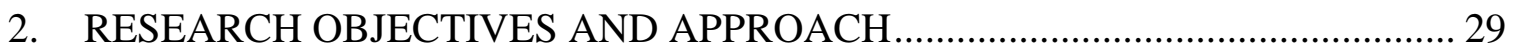

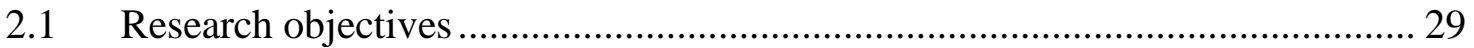

$2.2 \quad$ Description of modeling tools used............................................................... 31

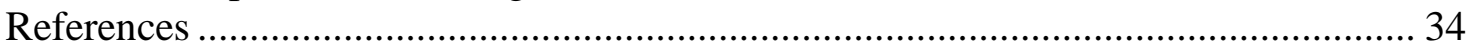

3. HYDRODGEOCHEMICAL ANALYSIS OF PROCESSES THROUGH MODELING OF SALTWATER INTRUSION IMPACTS IN BISCAYNE

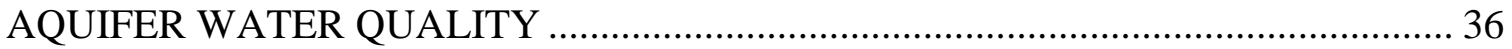

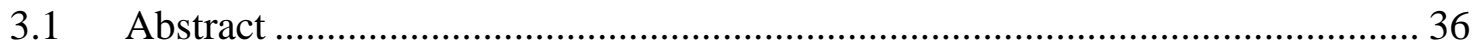

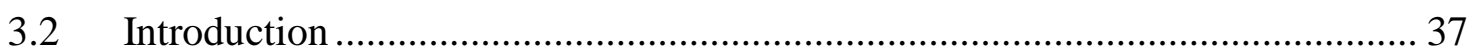

3.3 Hydrogeochemistry of the Biscayne Aquifer...................................................... 38

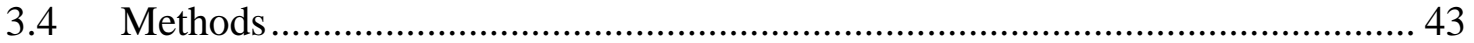

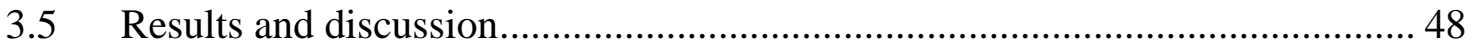

3.5.1 Piper diagram ..................................................................................... 48

3.5.2 Saturation indices (SI)......................................................................... 49

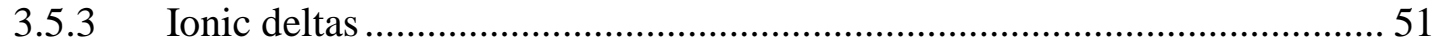

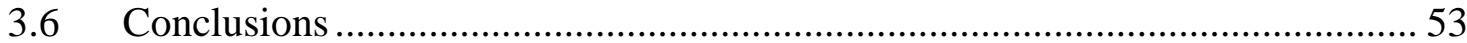

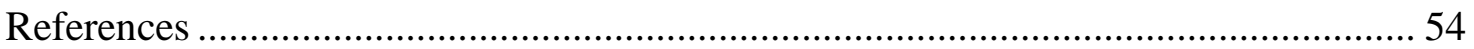

4. GROUNDWATER MIXING AND URANIUM SPECIATION IN

UNCONFINED AND CONFINED CARBONATE AQUIFERS..................................... 59

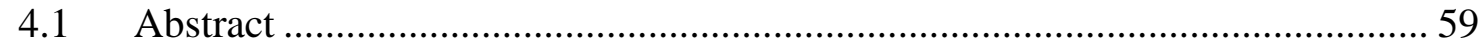

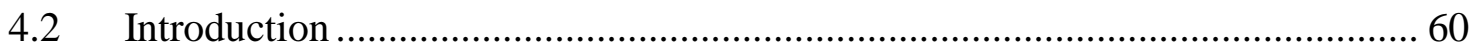

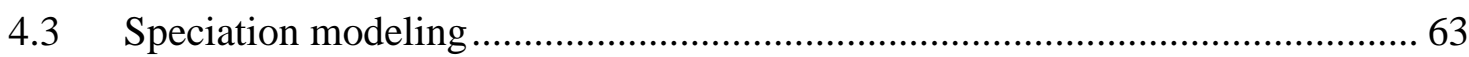

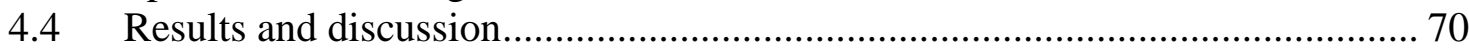

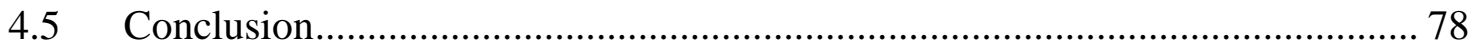

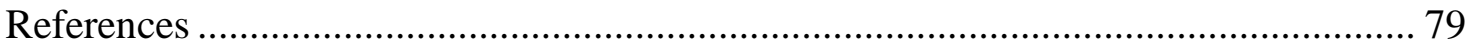

5. ANALYSIS OF WATER QUALITY IN THE FLORIDAN AQUIFER SYSTEM. 82

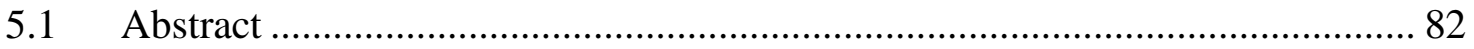

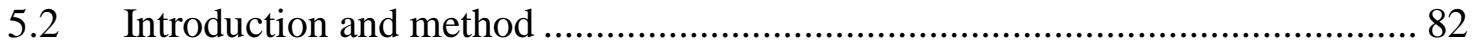




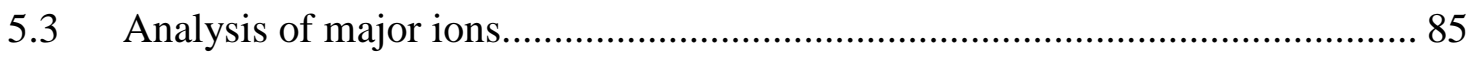

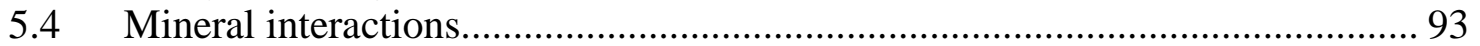

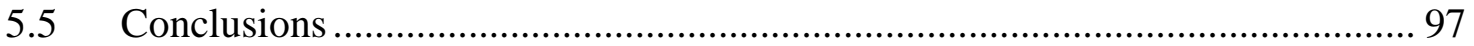

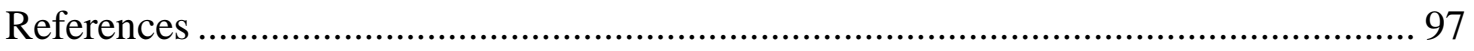

6. MODELING FLOW AND REACTIVE TRANSPORT OF ASR OPERATIONS

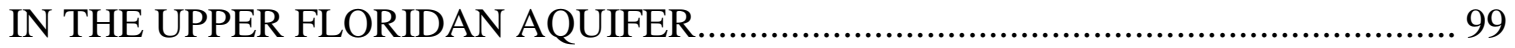

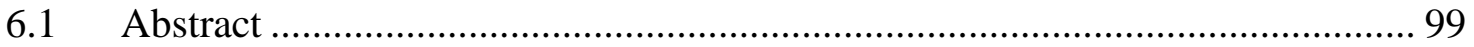

6.2 Introduction to numerical simulation of ASR .................................................... 99

6.3 ASR in South Florida ................................................................................. 104

6.4 Geochemical modeling at the Kissimmee River ASR (KRASR) ..................... 106

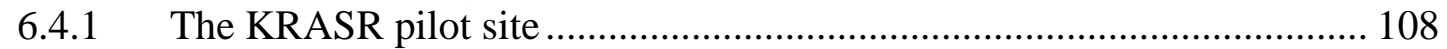

6.4.2 Inverse modeling................................................ 108

6.5 Reactive transport modeling of KRASR cycle tests ........................................ 114

6.5.1 Conceptual model setup ....................................................................... 114

6.5.2 Initial conditions and model calibration …………................................... 119

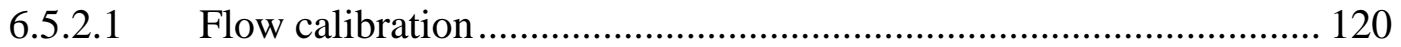

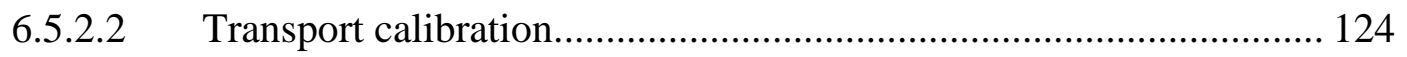

6.5.3 Dissolution-precipitation and ion exchange reactions at the KRASR ...... 131

6.6 Fate of arsenic (As) at KRASR ………………............................................ 133

6.6.1 Measurements of Fe, DO and As at KRASR.......................................... 133

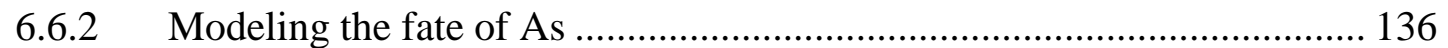

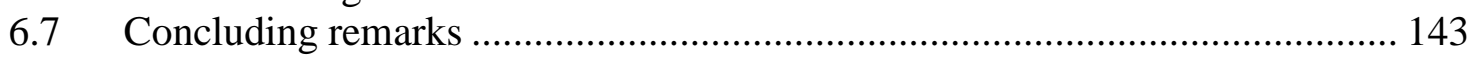

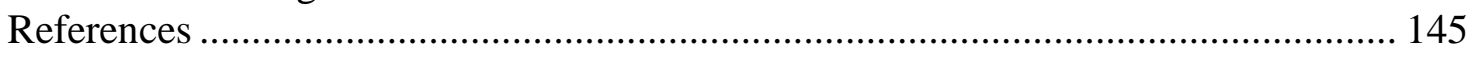

7. MULTI-OBJECTIVE OPTIMIZATION OF WATER SUPPLY

MANAGEMENT AND AUGMENTATION IN THE BISCAYNE AQUIFER ............ 148

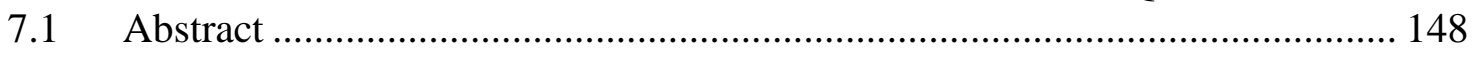

7.2 Simulation-optimization of groundwater management...................................... 148

7.3 Description of the management method.......................................................... 152

7.4 Simulation-optimization method used …………........................................... 153

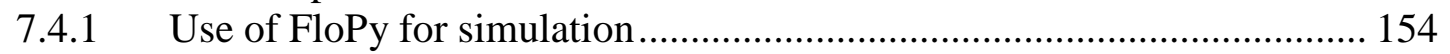

7.4.2 Use of DEAP for optimization................................................................ 154

7.5 Application to the case of Coconut Grove, Miami............................................. 158

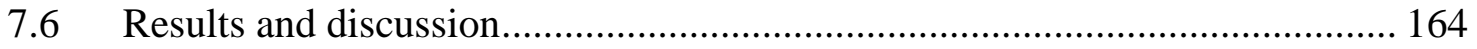

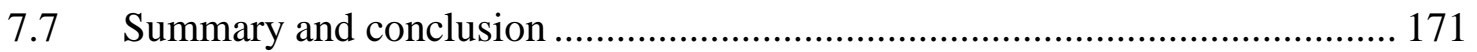

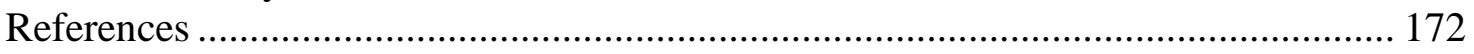

8. CONCLUSIONS AND RECOMMENDATIONS ................................................ 175

8.1 Summary and conclusions...................................................................... 175

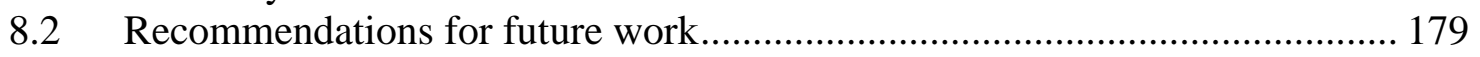

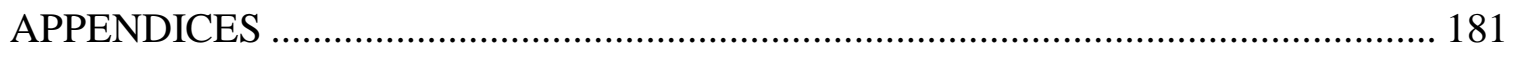

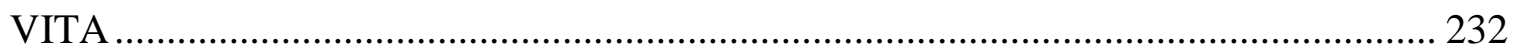




\section{LIST OF TABLES}

TABLE

PAGE

Table 3.1 Water quality of wells selected in the study ${ }^{\dagger}$

Table 3.2 Temperature (T) and chemical compositions of the freshwater and saltwater end members used in modeling.... 46

Table 4.1 Aqueous Uranium species and their formation constants used in modeling. ... 65

Table 4.2 Groundwater quality of samples from the mixing zone of the Biscayne Aquifer 68

Table 4.3 Average Upper Floridan Aquifer (UFA) and recharge water qualities at KRASR (Mirecki et al., 2012).

Table 4.4 Effect of equilibrium with calcite (Equil.) compared to mixing only (Mix).

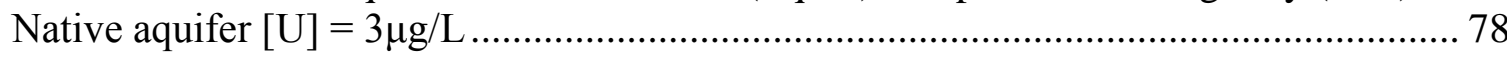

Table 5.1: Average compositions of the freshwater and saltwater end members used in the modeling.....

Table 6.1 Summary of common flow and transport codes, GUIs and model calibration programs 102

Table 6.2. Recharge and native water quality at the ASR (EXKR-1) well and at the monitoring well at $1100 \mathrm{ft}$. Water quality at the end of storage and recovery in cycle 1 are also shown.

Table 6.3. Computed saturation index of important minerals for the water compositions in Table 6.2

Table 6.4 Results of inverse modeling at KRASR

Table 6.5 Average pumping rates and durations during KRASR cycle tests 118

Table 6.6 Kinetic reaction network included in modeling the fate of arsenic 140 


\section{LIST OF FIGURES}

FIGURE

PAGE

Figure 1.1 Location of the Biscayne Aquifer (Barlow, 2003) ........................................ 3

Figure 1.2. Saltwater intrusion in the Biscayne Aquifer in Miami-Dade County, near the Miami Canal (Barlow and Reichard, 2010). 5

Figure 1.3. Chloride data from selected sites in South Florida as of August 31, 2012. USGS database (http://www.sflorida.er.usgs.gov/sal_data/index.html).....

Figure 1.4. Movement of the saltwater front around the FKAA well field, 19962001 (Peters, 2008). Crossed circles are monitoring wells

Figure 1.5: Generalized geology and hydrogeology of Southern Florida (Reese and Alvarez-Zarikian, 2007).

Figure 3.1 Location of monitoring wells used in the study and the approximate inland extent of saltwater, representing the $1000 \mathrm{mg} / \mathrm{L}$ isochlor, in 2011 (Prinos et al, 2014).

Figure 3.2 Piper diagram of the groundwater samples 49

Figure 3.3 SI of the samples and theoretical mixing with respect to calcite, dolomite, gypsum, aragonite and halite. Partial pressure of $\mathrm{CO}_{2}$ in the samples, together with modeled mixing line is also shown.....

Figure 3.4 Observed ionic concentrations and theoretical mixing lines

Figure 4.1 Correlation between $\mathrm{U}$ and $\mathrm{Cl}$ in Biscayne Aquifer samples, [U] > $1 \mu \mathrm{g} / \mathrm{L}$.

Figure 4.2 Speciation as a function of $\mathrm{pH}$ (top) and speciation against $\mathrm{Ca}^{2+}$ in the mixing zone of the Biscayne Aquifer (bottom).

Figure 4.3 Theoretical speciation curves for freshwater of the Biscayne Aquifer (top) and Eh-pH diagram for aqueous species and solid phases of the $\mathrm{Ca}-\mathrm{U}-\mathrm{O}_{2}-\mathrm{C}-$ $\mathrm{H}_{2} \mathrm{O}$ system at $25^{\circ} \mathrm{C}$ (bottom). 
Figure 4.4 Theoretical speciation of native UFA water at KRASR. 76

Figure 4.5 Variations of $\mathrm{U}, \mathrm{pH}$ and $\mathrm{pE}$ with fraction of recharge. 77

Figure 4.6 Dominant species in mixtures of UFA water and recharge water. Bold percentages are fractions of recharge water in the mixture. 77

Figure 5.1 Location of FAS monitoring wells in the region covered by SFWMD (from DBHYDRO)

Figure 5.2 Increased $\mathrm{Na}$ and $\mathrm{Cl}^{-}$at well PBF-15 (upper, middle and lower aquifers)

Figure 5.3. Ionic deltas for FAS samples (open circles) of RFGW project collected in the year 2007. Red lines are concentrations from simulated mixing between freshwater and saltwater.

Figure 5.4. Mineral saturation indices in the FAS. Red dots are SI of the samples and the lines are SI for the simulated mixing between freshwater and saltwater at different fractions of saltwater.

Figure 6.1. Local scale model (LSM) boundary and location of wells at the KRASR. Adapted from USACE (2012).

Figure 6.2 Ionic deviations from simple mixing at the ASR well during recovery of cycles 1-3.

Figure 6.3 Hydrogeologic cross section of the KRASR system. EXKR-1 is the ASR well and the other wells are monitoring wells (USACE, 2012).

Figure 6.4 Model extent, discretization and boundary conditions for the reactive transport model

Figure 6.5 Flowcharts for a) PHAST model and b) PEST optimization processes

Figure 6.6 Simulated and measured heads at OKF-100U. Head versus time (top) for LSM model and the current PEST-PHAST model and comparison of measured versus PEST-PHAST modeled head (bottom) 
Figure 6.7 Preferential FZ and $\mathrm{Cl}$ concentration at end of cycle 1 in the model domain. Pink dots are the ASR well screen. Color bar represents chloride concentrations in $\mathrm{mg} / \mathrm{L}$. Preferential flow can be seen on the thin FZ layer.

Figure 6.8 Conservative transport simulation (lines) and measured concentrations (dots) of some major ions at EXKR-1. Phases of each cycle are color coded; injection (pink), recovery (blue) and storage (white).

Figure 6.9 Conservative transport simulation (lines) and measured concentrations (dots) of some major ions at MW-10. Phases of each cycle are color coded; injection (pink), recovery (blue) and storage (white).

Figure 6.10 Evolution of calcite dissolution-precipitation in cycle 3 of KRASR. Calcite saturation index are calculated at monitoring wells MW-10 and OK-100U

Figure 6.11 Measured DO concentrations at KRASR. Concentrations are in mg/L and are shown for cycles 1-3 at monitoring wells MW-10 (left) and OKF-100U (right)

Figure 6.12 Reactive transport simulation (lines) and measured concentrations (dots) of reactive constituents and trace metals at EXKR-1....

Figure 6.13 Reactive transport simulation (lines) and measured concentrations (dots) of reactive constituents and trace metals at MW-10.

Figure 7.1 A Pareto front of the flight example.................................150

Figure 7.2 Flow chart of linked simulation-optimization processes 1577

Figure 7.3 Model discretization and boundary conditions. Adapted from Langevin (2001). 16161

Figure 7.4 Schematic sketch of decision variables used in the management model .... 1622

Figure 7.5 TDS in the steady-state pre-management simulation. Concentrations are shown in $\mathrm{Kg} / \mathrm{m}^{3}$. White arrows indicate flow velocity vectors. The 0.5 isoconcentration contour is the EPA secondary drinking water standard for TDS. ..... 1666

Figure 7.6 Pareto-front of solutions to the ADR management problem 1677 
Figure 7.7 Salinity (TDS) distribution after application of the ADR management model for select individuals in the Pareto front. [1565, 432, 1, 5800, 400, 32, 22 , 34.6] (top) and ADR [526, 430.4, 54, 5800, 400, 40, 38, 34.7] (bottom)

Figure 7.8 Transient simulations of TDS for the ADR management with the individual [1565, 432, 1, 5800, 400, 32, 22, 34.6]. TDS distributions remain the same after 10 years of management.

Figure 7.9 Pareto solutions of different SWI management scenarios. RD stands for recharge with desalinated water. 


\section{ABBREVIATIONS AND ACRONYMS}

ADR

ANN

APPZ

APT

ASR

ARD

BZ

CEC

CERP

DO

DOC

DOM

EPA

ESRI

FAS

FDEP

FKAA

FZ

GA

GUI

$\mathrm{HCO}_{3}$

HFO
Abstraction-Desalination- Recharge

Artificial Neural Network

Avon Park Permeable Zone

Aquifer Performance Test

Aquifer Storage and Recovery

Advection-Reaction-Dispersion

Boulder Zone

Cation Exchange Capacity

Comprehensive Everglades Restoration Plan

Dissolved Oxygen

Dissolved Organic Carbon

Dissolved Organic Matter

Environmental Protection Agency

Environmental Systems Research Institute

Floridan Aquifer System

Florida Department of Environmental Protection

Florida Keys Aqueduct Authority

Flow Zone

Genetic Algorithm

Graphic User Interface

Bicarbonate

Hydrous Ferric Oxide 


\begin{tabular}{|c|c|}
\hline ICU & Intermediate Confining Unit \\
\hline LF & Lower Floridan Aquifer \\
\hline LSM & Local Scale Model \\
\hline $\mathrm{MC}$ & Middle Confining unit of the FAS \\
\hline MCL & Maximum Contaminant Level \\
\hline MDL & Minimum Detection Limit \\
\hline MDWASD & Miami-Dade Water and Sewer Department \\
\hline MGD & Million Gallons per Day \\
\hline MOO & Multi-objective Optimization \\
\hline NSGA-II & Nondominated Sorting Genetic Algorithm \\
\hline $\mathrm{RE}$ & Recovery Efficiency \\
\hline RFGW & Regional Floridan Groundwater project \\
\hline SFWMD & South Florida Water Management District \\
\hline SI & Saturation Index \\
\hline SWI & Salt Water Intrusion \\
\hline TDS & Total Dissolved Solids \\
\hline UFA & Upper Floridan Aquifer \\
\hline USDW & Underground Source of Drinking Water \\
\hline USGS & United States Geological Survey \\
\hline USACE & United States Army Corps of Engineers \\
\hline WTP & Water Treatment Plant \\
\hline WWTP & Wastewater Treatment Plant \\
\hline
\end{tabular}




\section{SYMBOLS}

\begin{tabular}{|c|c|}
\hline As & Arsenic \\
\hline $\mathrm{C}$ & Carbon \\
\hline $\mathrm{Cd}$ & Cadmium \\
\hline $\mathrm{Cl}$ & Chloride \\
\hline Co & Cobalt \\
\hline $\mathrm{Cr}$ & Chromium \\
\hline $\mathrm{Fe}$ & Iron \\
\hline K & Potassium \\
\hline $\mathrm{Mg}$ & Magnesium \\
\hline $\mathrm{Na}$ & Sodium \\
\hline $\mathrm{Ni}$ & Nickel \\
\hline $\mathrm{Mn}$ & Manganese \\
\hline $\mathrm{Pb}$ & Lead \\
\hline S & Sulfur \\
\hline Se & Selenium \\
\hline $\mathrm{SiO}_{2}$ & Silicon Dioxide \\
\hline $\mathrm{SO}_{4}{ }^{2-}$ & Sulfate \\
\hline $\mathrm{Sr}$ & Strontium \\
\hline Th & Thallium \\
\hline $\mathrm{U}$ & Uranium \\
\hline $\mathrm{Ci}$ & Concentration of species $i$ \\
\hline $\mathrm{S}_{\mathrm{i}}$ & Mass of solute $i$ adsorbed per unit mass of solid phase \\
\hline
\end{tabular}




\begin{tabular}{|c|c|}
\hline$R_{i}$ & Retardation coefficient of solute $i$ \\
\hline$\rho_{b}$ & Bulk density of an aquifer \\
\hline$\theta$ & Effective porosity \\
\hline$S$ & Strong sorption site \\
\hline$w$ & Weak sorption site \\
\hline$\Psi$ & Surface potential (volts) \\
\hline$F$ & Faraday’s constant (C/mol) \\
\hline$R$ & Ideal gas constant \\
\hline$T$ & Temperature \\
\hline Eh & Redox potential \\
\hline$r$ & Rate of reaction \\
\hline$k$ & Reaction rate constants \\
\hline$I A P$ & Ion activity product \\
\hline$f_{\text {sea }}$ & Seawater fraction in a mixture \\
\hline$P_{i}$ & Partial pressure of gas phase $i$ (atmospheres) \\
\hline$a_{i}$ & Activity of species $i$ in aqueous phase \\
\hline$Q A$ & Rate of groundwater abstraction (m3/d) \\
\hline$Q R$ & Rate of aquifer recharge (m3/d) \\
\hline$L A$ & Location of abstraction well (m) \\
\hline$L R$ & Location of recharge well (m) \\
\hline$D A$ & Depth of abstraction well (m) \\
\hline$D R$ & Depth of recharge well (m) \\
\hline
\end{tabular}




\section{INTRODUCTION}

\subsection{Motivation}

The Biscayne Aquifer is a primary source of water supply in Southeast Florida, including Miami-Dade, Broward and Southeastern part of Palm Beach Counties. It also serves the Florida Keys, which pump water from the mainland in Southwest MiamiDade. Serving the public water supply needs of more than 4 million people (Marella, 2009), the Biscayne Aquifer has been designated a sole-source aquifer by the US Environmental Protection Agency (EPA). As a coastal aquifer, this fresh water storage is threatened by saltwater intrusion when the net freshwater flow is altered. Hydraulic stresses that reduce freshwater flow in Southeast Florida are groundwater pumping and the lowering of the water table by canal drainage. Seawater intrusion (SWI) is detrimental to the quality of freshwater sources, whereby less than $1 \%$ seawater renders the freshwater unfit for drinking (Werner et al., 2013). Chemical reactions between the aquifer material and the intruded groundwater determine the resulting water quality. Besides, such changes can alter the hydraulic properties of the aquifer because of carbonate dissolution. Due to species redistribution and non-linear dependence of activity coefficients on ionic strength, a mixture of two waters which are saturated with carbonate can become under-saturated for the carbonate. Thus carbonate dissolution can occur in a mixing zone even though both the freshwater and saltwater end-members are saturated with carbonates (Appelo and Postma, 2010; Rezaei et al., 2005; Sanford and Konikow, 1989; Werner et al., 2013; Wigley and Plummer, 1976). Carbonate dissolution enhances porosity and may lead to cave and karst formation (Appelo and Postma, 2010; Werner et al., 2013). Carbonate dissolution is complex and a reactive transport modeling 
is usually needed to properly understand the process (Rezaei et al., 2005). Cation exchange is the next important reaction in SWI. During SWI, $\mathrm{Na}^{+}$displaces $\mathrm{Ca}^{2+}$ from the exchanger. Cation concentrations should also increase to balance the increased $\mathrm{Cl}^{-}$due to salinity effect. Thus, ion exchange alters the concentrations of cations in the solution. Seawater has a high content of sulfate and when it intrudes an anoxic coastal aquifer, this may result in sulfate reduction due to degradation of organic matter (Werner et al., 2013). Coastal aquifer management involves SWI remediation and mitigation, such as regulating pumping or enhancing aquifer recharge (Werner et al., 2013). The development of models that can predict the location of the saltwater interface and associated water quality changes are, therefore, an important management tool. Increasing water demand, complex environmental issues and more stringent regulations have made water departments in South Florida develop alternative water supply plans to meet projected water demand and to sustainably use the Biscayne Aquifer. Alternative water supplies include use of the Upper Floridian Aquifer for Aquifer Storage and Recovery (ASR). Miami-Dade County is also part of a bigger restoration plan called the Comprehensive Everglades Restoration Plan (CERP) which is designed to enlarge South Florida's supply of fresh water and to improve water delivery to the natural areas. This plan proposes to construct 333 ASR wells to provide flexible water supply and storage to Lake Okeechobee and other areas. Thus, sustainable use of the Biscayne Aquifer includes SWI management and development of alternative water supplies for supply augmentation and adaptation to saltwater intrusion. 


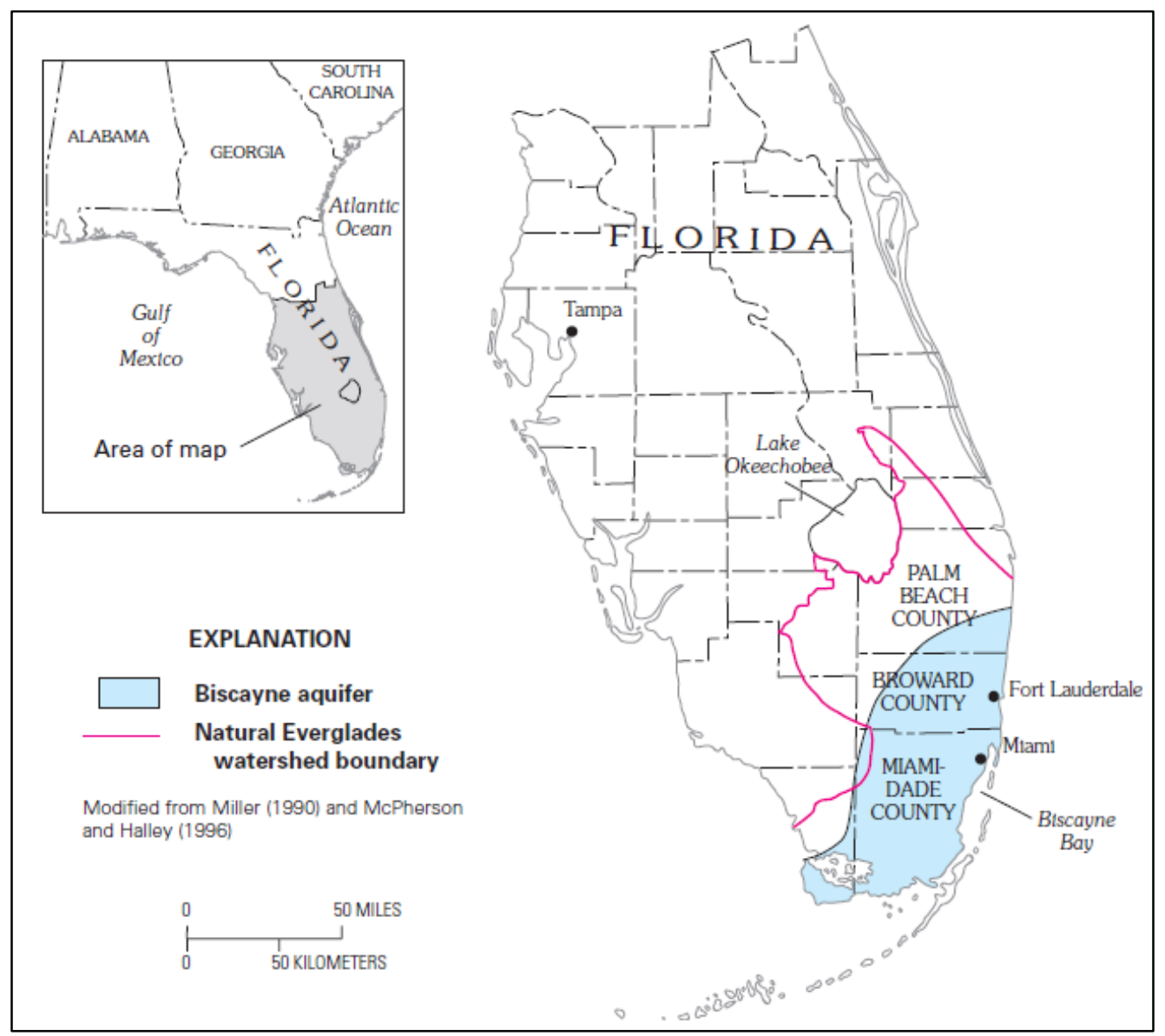

Figure 1.1 Location of the Biscayne Aquifer (Barlow, 2003)

\subsection{Saltwater intrusion in Southeast Florida}

Saltwater intrusion has been an issue of concern in Southeastern Florida since the 1930s. Drainage of the Everglades resulted in progressive inland migration of the saltwater interface until the canals were gated in 1946 (Barlow and Reichard, 2010). Additionally, harsh droughts and changes in wellfield operations have contributed to salt water intrusion in Southeast Florida (Sonenshein, 1997). Figure 1.2 shows the progression of saltwater intrusion near the Miami Canal between the years 1902 and 1995 and SWI was pronounced along the canals before they were gated in 1946. Important 
geochemical changes occur during SWI with carbonate dissolution being frequent in carbonate aquifers. Other changes driven by cation exchange and sulfate reduction are also possible. 


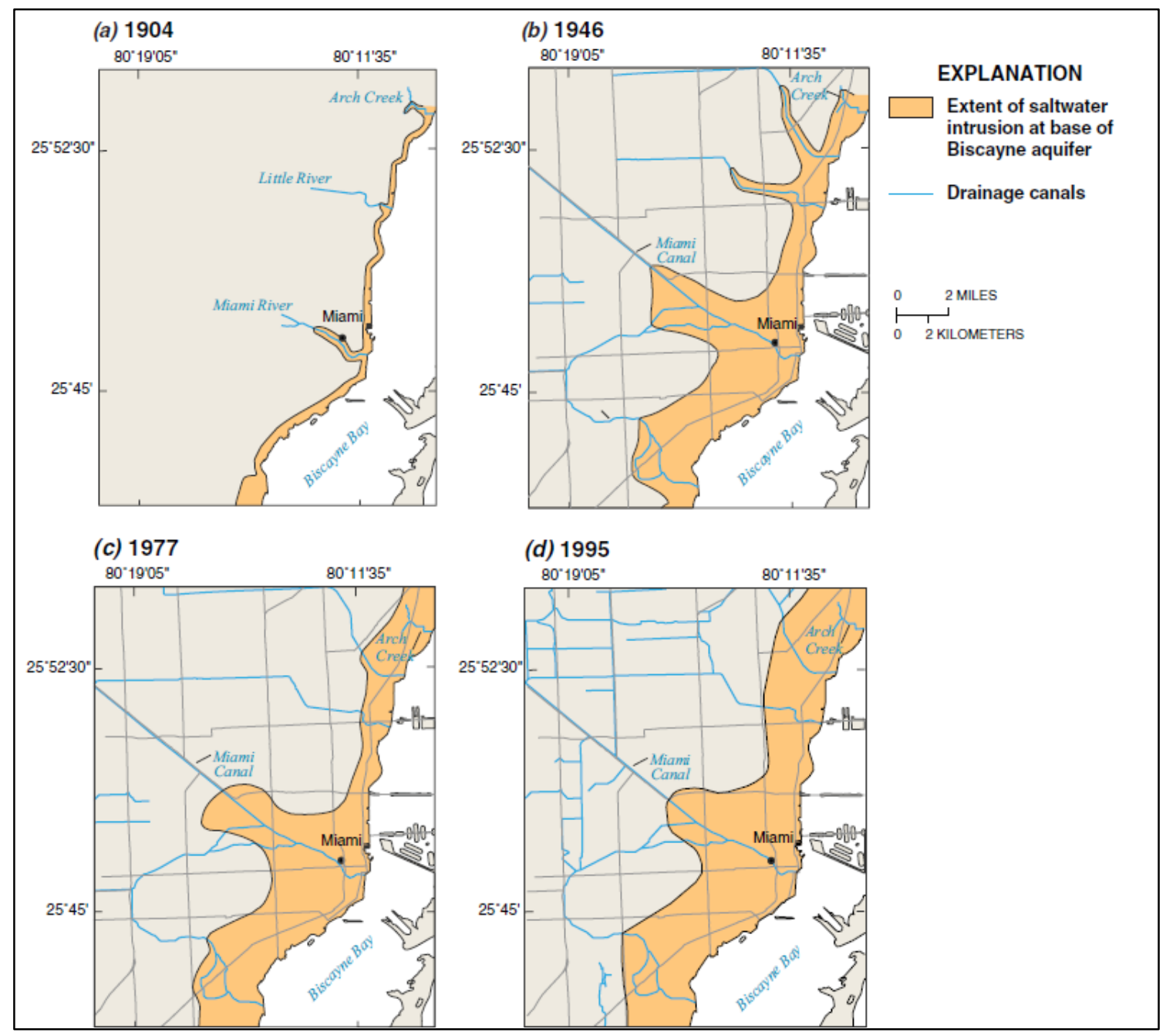

Figure 1.2. Saltwater intrusion in the Biscayne Aquifer in Miami-Dade County, near the Miami Canal (Barlow and Reichard, 2010) 


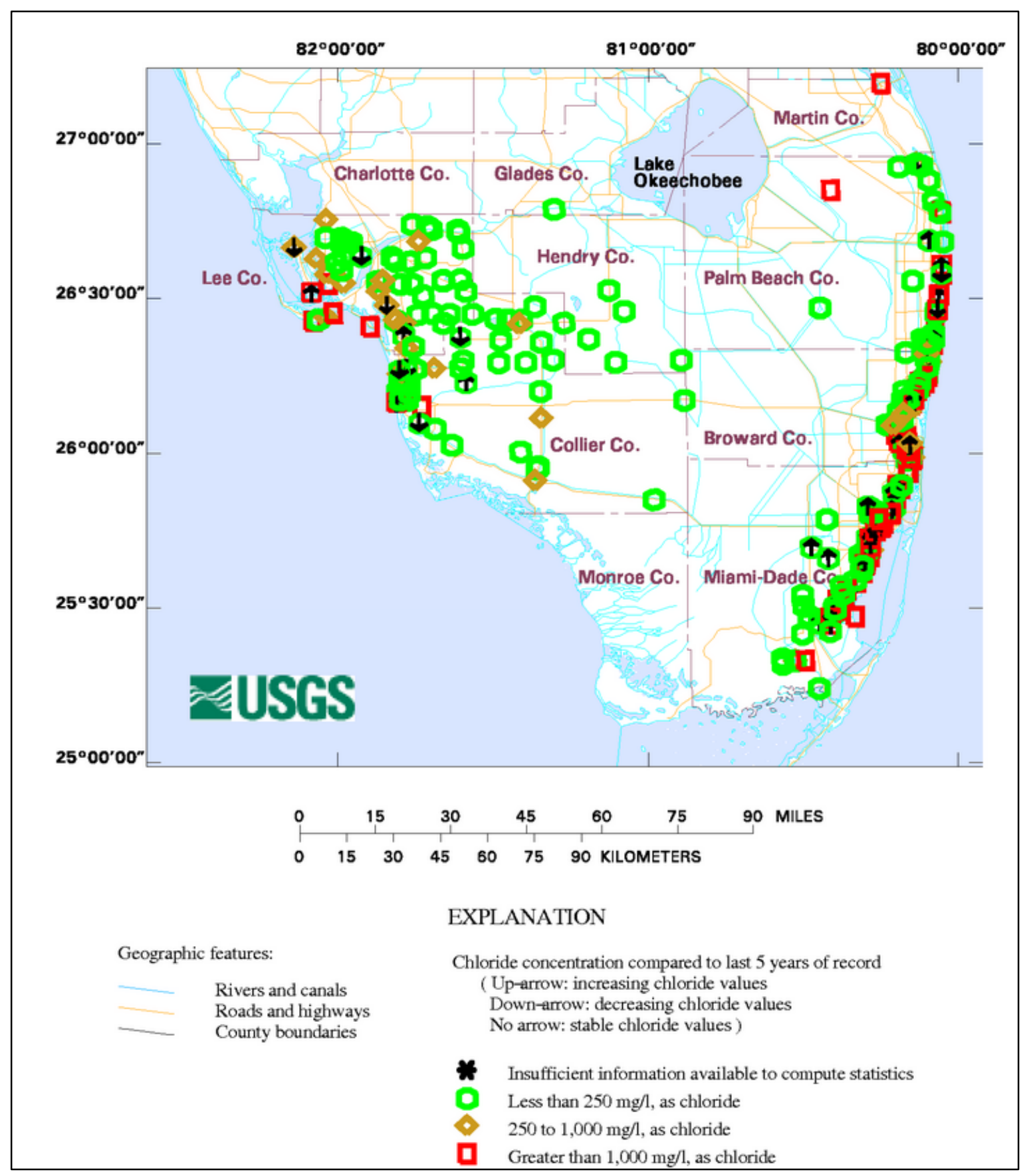

Figure 1.3. Chloride data from selected sites in South Florida as of August 31, 2012. USGS database (http://www.sflorida.er.usgs.gov/sal_data/index.html) 
Figure 1.3 shows chloride concentration in South Florida, as of August 31, 2012. Saltwater intrusion is evident along the coasts in Lee, Palm Beach, Broward and MiamiDade counties. The chloride concentrations in the affected wells exceed $1000 \mathrm{mg} / \mathrm{L}$ and may reach as high as 40,000 mg/L. Figure 1.3 also shows trends in chloride concentration in comparison to last 5-years'data. While chloride concentrations are stable for most inland locations (chloride changes less than $0.01 \mathrm{mg} / \mathrm{L} / \mathrm{year}$ ), they increase for a number of wells along the east coast. In almost all of the inland wells, chloride is less than the MCL of $250 \mathrm{mg} / \mathrm{L}$ and has been stable for the past 5 years. However, in a few inland locations in Miami-Dade County, the chloride concentration has been increasing (green circles with arrows pointing up in Figure 1.3). The saltwater front is dynamic depending on groundwater pumping and natural recharge frequency. It may also “jump” during periods of drought and hurricanes. Figure 1.4 shows movement of the saltwater front near the FKAA wellfield in Miami-Dade County. The front appears to have retreated in the years 2000 and 2001. Saltwater intrusion, therefore, appears progressive for long time frames (e.g., decades) while it appears to go back and forth in shorter durations (e.g., years). 


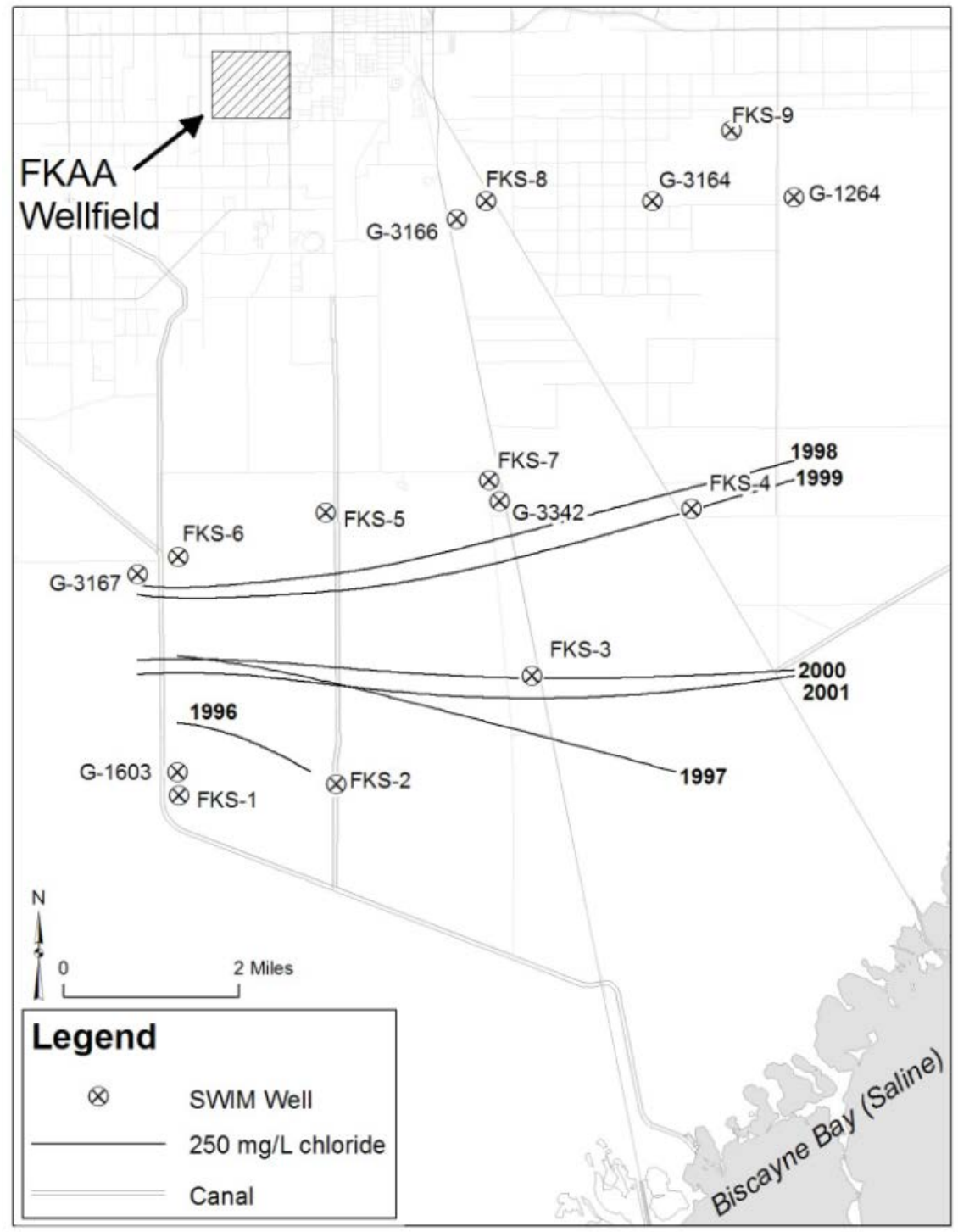

Figure 1.4. Movement of the saltwater front around the FKAA wellfield, 1996-2001 (Peters, 2008). Crossed circles are monitoring wells 


\subsection{Geochemical processes in mixing zones}

a) Mixing

Seawater intrusion involves mixing between saline and fresh groundwater end members. Because of its significant salt content, a small fraction of seawater would dominate the chemical composition of groundwater. Contribution of $5 \%$ seawater, for example, would result in water with chloride exceeding $1000 \mathrm{mg} / \mathrm{L}$ if initial groundwater has $100 \mathrm{mg} / \mathrm{L}$ chloride (Bear et al., 1999). Just $1 \%$ of seawater is enough to make the fresh groundwater unfit for drinking (Werner et al., 2013). Chloride is thus usually used as an indicator of saltwater intrusion because of its conservative behavior. Stable isotopes of $\mathrm{O}$ and $\mathrm{H}$ behave similarly and have been used to describe mixing between freshwater and saline water.

\section{b) Exchange and adsorption reactions}

Cation exchange is a very common process during saltwater intrusion and has been discussed in detail in various studies (Appelo and Postma, 2010; Appelo, 1994). Freshwater in coastal areas is usually of the $\mathrm{Ca}-\mathrm{HCO}_{3}$ type while seawater is a $\mathrm{Na}-\mathrm{Cl}$ type. Thus in freshwater, $\mathrm{Ca}^{2+}$ is adsorbed to exchangers, such as clay and organic matter. When seawater intrudes, $\mathrm{Na}^{+}$replaces $\mathrm{Ca}^{2+}$ from the exchanger resulting in excess of $\mathrm{Ca}^{2+}$

$$
\mathrm{Na}^{+}+0.5 \mathrm{Ca}-\mathrm{X}_{2} \rightarrow \mathrm{Na}-\mathrm{X}+0.5 \mathrm{Ca}^{2+}
$$

where $X$ : indicates the soil exchanger, $\mathrm{Ca}-\mathrm{X}_{2}$ is $\mathrm{Ca}$ adsorbed to the exchanger and $\mathrm{Na}-\mathrm{X}$ is $\mathrm{Na}$ adsorbed to the exchanger. The change in solute composition results in a $\mathrm{CaCl}_{2}$ type water. $\mathrm{CaCl}_{2}$ water often has a low $\mathrm{pH}(<7)$ which may be due to calcite 
precipitation, driven by excess $\mathrm{Ca}^{2+}$. $\mathrm{Mg}^{2+}$ and $\mathrm{K}^{+}$also undergo changes in concentration during saltwater intrusion or freshening of an aquifer depending on the aquifer properties and their concentrations in the freshwater. Commonly, $\mathrm{Mg}^{2+}$ is enriched along with $\mathrm{Ca}^{2+}$ (Bear et al., 1999). In this case the excess cations should be balanced by the depleted cations.

The rate and extent of ion exchange reactions is limited by the number of available exchange sites. The total exchange capacity of an aquifer is described in terms of its cation exchange capacity (CEC), expressed in meq/Kg. CEC is mainly dependent on clay and organic matter content of the aquifer. An empirical formula can be used to calculate CEC near neutral pH (Appelo and Postma, 2010)

$$
\text { CEC }(\text { meq } / \mathrm{Kg})=7 *(\% \text { clay })+35 *(\% \mathrm{C})
$$

Cations that commonly occupy the CEC sites are $\mathrm{Ca}^{2+}, \mathrm{Mg}^{2+}, \mathrm{Na}^{+}$and $\mathrm{K}^{+}$; their order of selectivity is $\mathrm{Ca}^{2+}>\mathrm{Mg}^{2+}>\mathrm{K}^{+}>\mathrm{Na}^{+}$. For adsorbed cations, calculation of activity coefficients is not straight forward and different conventions are used (Appelo and Rolle, 2010). The effect of using different conventions is most notable in hetrovalent cation exchange where higher charged ions are preferred more strongly as the solute concentration decreases. The Gapon convention is popular among soil scientists but it doesn’t perform well when several hetrovalent cations are present. The Gaines-Thomas convention is used more commonly and it is the convention used in the databases phreeqc.dat and wateq4f.dat, which are distributed with PHREEQC. It is also possible to use the other conventions in PHREEQC using simple conversions (Parkhurst and Appelo, 1999). Description of the PHREEQC code is given in section 2.2. 
Ion-exchange data can be represented in the form of isotherms which are plots of the equilibrium concentration of ions in the exchanger versus equilibrium concentrations of the same ions in the co-existing solution phase. In its simplest form, the distribution coefficient is defined by a linear isotherm.

$$
K_{d}=\frac{S_{i}}{C_{i}}
$$

where $S_{\mathrm{i}}(\mathrm{mg} / \mathrm{Kg})$ is the mass of solute $i$ adsorbed per unit mass of solid phase and $\mathrm{C}_{\mathrm{i}}$ (mg/L) is the concentration of solute $i$ in solution. The retardation of the solute during groundwater movement is given by its retardation factor.

$$
R_{i}=1+\frac{\rho_{b}}{\theta} K_{d}
$$

where $\rho_{b}$ is the bulk density of the aquifer and $\theta$ is the effective porosity. The linear model assumes that the sorption sites are unlimited. In reality, the sorption sites are limited and once these are filled, no more sites can be occupied. The Langmuir isotherm takes this into consideration. According to the Langmuir isotherm,

$$
S_{i}=\frac{K_{i} b C_{i}}{1+K_{i} C_{i}}
$$

where $\mathrm{K}_{\mathrm{i}}$ is equilibrium constant for reactions of the type $L+C_{i}=L C_{i}$, $\mathrm{L}$ is concentration of a surface site, $C_{i}$ is the concentration of an adsorbing ion and $L C_{i}$ is the concentration of sites $L$ occupied by the adsorbing ion. Thus, Ki can be written as:

$$
K_{i}=\frac{\left[L C_{i}\right]}{[L]\left[C_{i}\right]}
$$


The Langmuir isotherm equilibrium constant is the same as the surface complexation constant except that it doesn't explicitly involve electrostatic forces (Zhu, 2002).

The isotherms are useful in partitioning of solids between aqueous and solid phases, such as adsorption of hydrophobic contaminants onto organic surfaces. Their use in environmental reactive transport models is, however, limited because these models oversimplify the geochemical reactions at many sites (Bethke, 2007; Zhu et al., 2001; Zhu, 2002).

\section{c) Surface Complexation}

The cation exchange concept works well for major cations, in general, and trace metals near neutral $\mathrm{pH}$. However trace metal adsorption varies with $\mathrm{pH}$ and it occurs in the 'stern' layer of a mineral surface unlike ion exchange which occurs in the diffuse layer (Zhu, 2002a). Because of trace metal competition with $\mathrm{H}^{+}$for sorption sites, trace metal sorption increases with increased pH (Appelo and Rolle, 2010).

A mineral surface has different types of binding sites but the number of types is a difficult parameter to quantify. The number of sites varies between models. For example, for hydrous ferric oxide (HFO), Dzombak and Morel (1990) conclude that two types of sites accommodate all experimental data. These are the strong and weak sites (labeled $s$ and $w$, respectively) which are included in the PHREEQC databases (Parkhurst and Appelo, 1999). The sorption site behaves like a complexing ligand and equilibrium equations can be written to quantify complexation reactions. Concentration of the sorption sites can be obtained from the amount of surface area and the density of sites in that area. Then a system of equations can be written for the reactions between the site and various ions. These equations can be solved by computer programs to give the 
concentrations of surface species and aqueous species. Different notations are used to distinguish the 'clean’ surface from the complex surface (Bethke, 2007; Dzombak and Morel, 1990; Parkhurst and Appelo, 1999). In PHREEQC, for example, the reactions between the clean and complex surface are related by the following (equation 1.7).

$$
H f o_{-}{ }_{w O H}+H^{+}=H_{f o}{ }_{w O H} \mathrm{H}_{2}^{+} \text {with } \log \mathrm{K}=7.29
$$

Sorption involves a chemical bond between the ion and the surface atoms and an electrostatic effect depending on the surface charge. The solid phase is electrically charged even in the absence of a solute. The whole system is electrically neutral because the solid phase induces an equal and opposite charge in the adjacent solution. To account for the effect of the charge, activities and equilibrium constants are adjusted in surface complexation models. The equilibrium constant shown in equation 1.7 is the value at the surface before any correction is applied. A correction for the change in Gibbs free energy for the change in potential between the solution and the surface (i.e., $\psi$ ) is needed. Another adjustment considers the net change in charge of the surface species, $\Delta \mathrm{z}$. The adjustment is given by Zhu (2002a) and shown in equation 1.8.

$$
K_{\text {solution }}=K_{\text {surface }} \exp \left(-\frac{\Delta z F \psi}{R T}\right)
$$

Where $K_{\text {solution }}$ is the equilibrium constant for the solution, $K_{\text {surface }}$ is the "intrinsic" or "surface" equilibrium constant, $\Delta \mathrm{z}$ is the net change in charge of the surface species, $\Psi$ denotes the surface potential (volts) and $\mathrm{T}$ is the temperature in Kelvin. The constants $\mathrm{F}$ and $\mathrm{R}$ represent Faraday's constant $(\mathrm{C} / \mathrm{mol})$ and ideal gas constant (8.314 J/mol-K), respectively. One way to calculate $\Psi$ from surface charge is given by Gouy-Chapman theory (Zhu, 2002a). With known site densities, equilibrium constants for each site and 
each solution component, the distribution of surface and aqueous species can now be solved.

\section{d) Dissolution-precipitation reactions}

Calcium concentration in carbonate aquifers is usually large because of reactions between carbonate minerals and carbon dioxide in the groundwater. The overall reaction (equation 1.9) is helpful to understand dissolution and precipitation of calcite.

$$
\mathrm{CO}_{2(g)}+\mathrm{H}_{2} \mathrm{O}+\mathrm{CaCO}_{3} \rightarrow \mathrm{Ca}^{2+}+2 \mathrm{HCO}_{3}^{-} \text {with } \mathrm{K}=10^{-6}
$$

An increase in $\mathrm{CO}_{2(g)}$ concentration due to root respiration or oxidation of organic matter causes dissolution of $\mathrm{CaCO}_{3}$ while degassing of $\mathrm{CO}_{2(g)}$ causes calcite precipitation. When two waters that are saturated with calcite are mixed (e.g., due to saltwater intrusion), they may become unsaturated with calcite causing calcite dissolution (Appelo and Postma, 2010). Kinetic dissolution of calcite depends on initial concentrations, $\mathrm{pH}$ and partial pressure of $\mathrm{CO}_{2(g)}$. Equation 1.10 is a common rate expression used in PHREEQC (Appelo and Postma, 2010). Equilibrium dissolution (equation 1.9) or kinetic dissolution of calcite (equation 1.10) can be used in modeling depending on the model's complexity.

$$
r=k_{1}\left[H^{+}\right]+k_{2}\left[H_{2} \mathrm{CO}_{3}\right]+k_{3}\left[\mathrm{H}_{2} \mathrm{O}\right]-k_{4}\left[\mathrm{Ca}^{2+}\right]\left[\mathrm{HCO}_{3}^{-}\right]
$$

Where $\mathrm{r}$ is the rate of calcite dissolution $\left(\mathrm{mmol} / \mathrm{cm}^{2} / \mathrm{s}\right), k_{1}, \ldots, k_{4}$ are the rate constants.

Dolomitization is a precipitation reaction involving formation of dolomite. Dolomitization would be indicated by an $\mathrm{Mg} / \mathrm{Ca}$ ratio (in meq/L) of more than 1 , depletion of Mg and excess Ca in relation to a theoretical mixing line (Pulido-Leboeuf, 2004). Ideal conditions for dolomitization are reached when $\mathrm{SI}_{\text {calcite }}<0$ and $\mathrm{SI}_{\text {dolomite }}>0$. 
Dolomite precipitation in solutions should satisfy the following equilibrium reaction (equation 1.11)

$$
\mathrm{Ca}^{2+}+\mathrm{Mg}^{2+}+2\left(\mathrm{CO}_{3}^{2-}\right)=\operatorname{CaMg}\left(\mathrm{CO}_{3}\right)_{2} \text { with } \mathrm{K}=10^{-17}
$$

Based on this equilibrium, modern seawater would be supersaturated by one or two orders of magnitude with respect to seawater, yet dolomite is a rare precipitate. This suggests the reaction is kinetically controlled.

\section{e) Redox reactions}

Redox processes in groundwater typically occur through addition of oxidants like dissolved oxygen (DO). During ASR, for example, injection of oxygen-rich water into an anoxic aquifer triggers redox processes that may cause redox dissolution of aquifer minerals and subsequent release of associated trace metals. The redox potential, $\mathrm{pE}$, determines the distribution of species defined by redox equilibrium. For example concentrations of the various oxidation states of arsenic can be computed from $\mathrm{pE}$ and total arsenic concentration. In PHREEQC, pE can be explicitly stated or it may be computed from concentrations of specified redox pairs.

\subsection{Hydrogeology and lithology of the Floridan Aquifer System (FAS)}

Generally, the aquifer system in Florida consists of the FAS, overlain by the Intermediate Aquifer System and the Surficial Aquifer System. The semi-confined Biscayne Aquifer forms the top of the surficial aquifer system (Bradner et al., 2005; Renken et al., 2005; Renken et al., 2008). The Biscayne Aquifer is 17 to 30 m thick in South Miami-Dade and gets thicker towards the coast. At its deepest location in northeastern Miami-Dade County, it is approximately $55 \mathrm{~m}$ thick (Prinos et al., 2014). The Biscayne Aquifer is one of the most productive karst aquifers with transmissivity 
values ranging between 0.4 and $3.1 \mathrm{~m}^{2} / \mathrm{s}$ (Fish and Stewart, 1991; Renken et al., 2008). The aquifer is comprised, from top to bottom, of Pamlico Sand, Miami Oolite, Anastasia Formation, Key Largo Limestone, Fort Thompson Formation and the Tamiami Formation (Bradner et al., 2005). The Pamlico Sand is fine to medium-grained quartz; the Oolites are commonly filled with lime mud and sand; the Anastasia Formation consists of shelly limestone and shelly sandstone; the Key Largo Limestone is very porous coralline limestone; and the Tamiami Formation consists of limestone, calcareous sand stone and sand. Thus the aquifer is chiefly made of limestone, dolomite, sand, clay and shells (Bradner et al., 2005).

The FAS is a vertically continuous sequence of Tertiary carbonate rocks that are of generally high permeability and are hydraulically connected in varying degrees. The aquifer system includes, in ascending order, the upper part of the Cedar Keys Formation, Oldsmar Formation, Avon Park Formation (within the middle confining unit), Ocala Limestone, Suwannee Limestone, and in some areas the lower part of the Hawthorn Group. The Suwannee Limestone and Ocala Limestone are absent in some parts of Southeastern Florida (Reese and Alvarez-Zarikian, 2007). The FAS consists of the Upper Floridan Aquifer (UFA) and the Lower Floridan Aquifer, separated by a middle confining unit. The UFA (50-1200 ft b.l.s.) is the primary aquifer used for ASR in Southern Florida (Reese and Alvarez-Zarikian, 2007). It is therefore imperative to understand the geochemical composition of the aquifer matrix and the ambient water in the UFA to understand geochemical reactions during ASR. Generally, the major minerals in the aquifer system are calcite, dolomite, and some local gypsum or quartz with minor minerals including apatite, glauconite, and clay minerals, such as kaolinite and 
montmorillonite. The hydrogeology is highly variable with respect to site location and exhaustive hydrogeologic investigation at a site of interest is an important raw material for geochemical modeling. The general hydrogeology and lithology of South Florida is summarized by Reese and Alvarez-Zarikian (Reese and Alvarez-Zarikian, 2007) and shown in Figure 1.5. Because of its unique hydrogeology and geochemistry, major geochemical processes expected in the UFA are (1) dissolution of aquifer minerals toward equilibrium, (2) mixing of groundwater with recharge, leakage, or seawater, (3) sulfate reduction, and (4) cation exchange between water and aquifer minerals.

\subsection{Aquifer storage and recovery (ASR) and its challenges}

For sustainable groundwater supply of the Biscayne Aquifer, some form of water supply augmentation may be needed. Based on a simple water budget, storage can be kept constant by adjusting inflow and outflow in the aquifer zone. The outflow represents the ever-increasing water supply demand which may not be easily controlled. One viable option is to augment the water supply by adding inflow to balance the excesses outflow. ASR is a technology for storing water in aquifers which uses the same well for injection and recovery (Pyne, 1995). It differs from conventional artificial recharge in that the same water that is recharged is intended to be recovered for use. ASR facilities were first operational in Florida in 1983 and most of the ASR facilities store water in the brackish waters of the Upper Floridan Aquifer (UFA) (Pyne, 1995). The technology has been applied in South Florida for many years and it is a viable option for cities to improve the reliability of their water sources. 


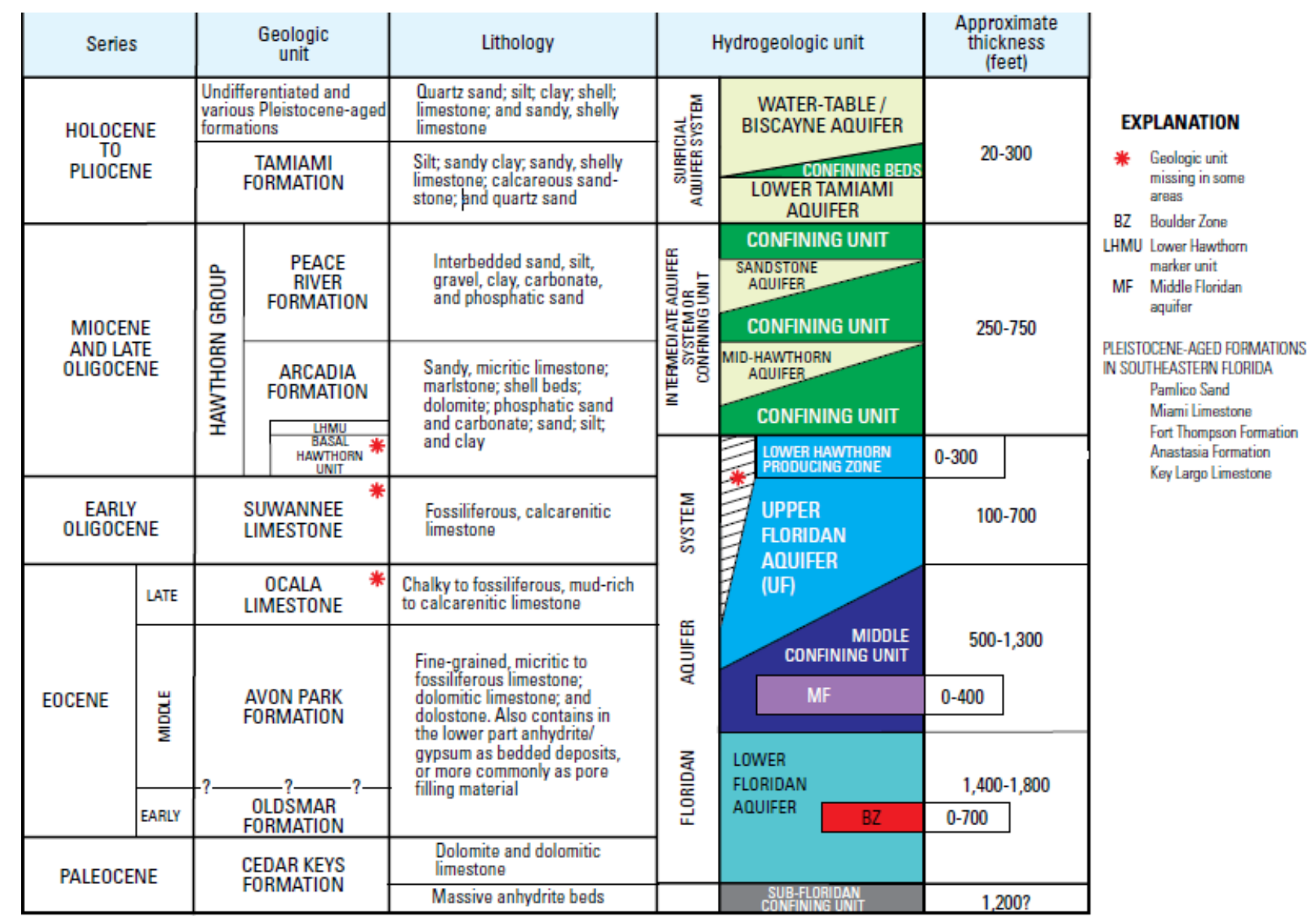

Figure 1.5: Generalized geology and hydrogeology of southern Florida (Reese and Alvarez-Zarikian, 2007). 
Despite its encouraging role in augmenting water supplies, ASR comes with its own challenges. Some of the challenges are changes in water quality due to mixing between ambient and recharge waters, mineral precipitation or dissolution that may lead to aquifer clogging, and mobilization of trace minerals, such as arsenic, copper and lead (Dillon et al., 2006;Herczeg et al., 2004;Pavelic et al., 2007;Vanderzalm et al., 2006). Excessive gas exsolving has also been observed during recovery of water from an ASR site in Las Vegas Valley (Solomon et al., 2011). In Florida, geochemical issues related to arsenic and pyrites have been very problematic. Current or potential ASR problems identified in South Florida include (Reese and Alvarez-Zarikian, 2007):

a) Low recovery efficiency

b) Geochemical changes due to recharge and the potential release of trace metals and radioactivity.

The usually low recovery efficiency in ASR systems has discouraged their wide-spread use in augmenting water supplies. About one-third of the wells tested by the USGS in South Florida, for example, had less than 10\% recovery (Reese and Alvarez-Zarikian, 2007). This means that only $10 \%$ of the injected water was recovered for the desired use. It also implies that a good portion of the injected water stays in the aquifer for long time, being susceptible to geochemical reactions after which successive recoveries may withdraw the geochemically altered water. Another possible challenge to ASR has been discussed by Maliva and others (Maliva et al., 2007). Maliva et al. (Maliva et al., 2007) investigated the possibility of vertical migration from deep waste water injection wells in the 'boulder zone' of the Floridan Aquifer System. Of the 32 active, Class 1 injection wells in Southeast Florida, upward migration of injected wastewater was detected or 
suspected in monitoring zones around ten injection wells. Upward migration of injected wastewater into Underground Source of Drinking Water (USDW) has been documented in three of those sites. The other seven sites are known or suspected to show upward migration into a monitoring zone below the base of the USDW. Interestingly, no vertical migration has been detected in any of the 23 operational injection wells in Southwest Florida because of very small hydraulic conductivities. But observed fracturing at some sites allowed for vertical migration of about $80 \mathrm{~m} / \mathrm{yr}$. Maliva et al. (2007) conclude that this migration is too slow for microorganisms to remain active upon arrival at potential sources of groundwater and rule out the risk to human health. However, this may need additional consideration from the point of view of changes to water quality due to the potential mixing of the vertical migrating water and the native groundwater in the overlying aquifer. It is important to note that the class 1 injected wastes include wastewater from municipal water reclamation facilities; concentrate from desalination facilities, landfill leachates and non-hazardous industrial wastewater. Other ASR challenges are mainly operational, such as the possibility of hydraulic fracturing and land subsidence. Desktop studies of potential ASR-induced pressure changes in the FAS can be found in (Geibel and Brown, 2012). Similar to SWI effects, ASR operations may result in changes of hydraulic conductivity because of aquifer clogging and dissolution of minerals (Du et al., 2013).

An understanding of the key factors affecting water quality and recovery efficiency is very helpful in the design and management of ASR. Cycle test data and other field observations in ASR can be interpreted to understand the basic processes responsible for the changes. However, these changes are not so intuitive as they result from nonlinear 
interactions of hydro-geochemical and bacterial processes. With the help of modeling, field data can best be explained and future predictions of changes in water quality can be made. In this regard, high resolution field monitoring and modeling would be an ideal combination.

\subsubsection{Water quality changes during ASR}

Mobilization of trace metals seriously affects ASR performance. The ASR site in Green Bay, Wisconsin was abandoned, for example, entirely due to the presence of arsenic, manganese, nickel, and cobalt in the recovered water (Brown et al., 2006). In Florida, geochemical reactions related to arsenic and pyrites have been very problematic where oxygen-rich surface waters cause the releases of trace metals, such as arsenic (As), iron (Fe), manganese (Mn), uranium (U) and nickel (Ni) (Arthur and Cowart, 2001). In many cycle tests performed by the Florida Department of Environmental Protection (FDEP), As has been recovered in excess of the maximum contaminant level (MCL) of $10 \mu \mathrm{g} / \mathrm{l}$ (Florida Department of Environmental Protection). As-bearing phases are strongly associated with $\mathrm{Al}, \mathrm{Cd}, \mathrm{Cr}, \mathrm{Co}, \mathrm{Fe}, \mathrm{La}, \mathrm{Ni}, \mathrm{Pb}, \mathrm{Se}, \mathrm{Sr}$, Th and $\mathrm{U}$, the majority of which are regulated under primary drinking water standards. However, only As has been recovered in excess of its MCL although some other trace metals show similar trends as As (Arthur and Cowart, 2001). Arsenic concentrations recovered in successive cycles depend on the volumes of injection and recovery. In multiple cycle tests, As concentrations are observed to decrease in successive cycles if the volumes injected in the cycles are similar because no "new" As-bearing aquifer is exposed (Mirecki et al., 2012). If the second injection is larger than the first cycle, however, greater As concentration is observed during the second cycle (Arthur and Cowart, 2001). 
Sometimes, it is suggested that continuous injection/recovery can flush As, provided the recovery volume doesn't exceed the injection volume. However, the mass of As flushed from the source is usually very small, making the idea ineffective. A reduction of only about $6 \%$ of the total As mass occurred after 7 cycles of testing in Australia (Wallis et al., 2011). Recently, Antoniou et al. (2015) showed significant reduction of As mobilization by controlling the chemistry of recharge water.

Sulfate concentrations also may increase during cycle tests because of gypsum dissolution, mixing, and microbe-mediated sulfate reduction. The U.S. Army Corps of Engineers (USACE) conducted a study of water quality changes in eleven South Florida ASRs. In these sites which are recharged with treated surface water, sulfate concentrations increase during cycle testing but do not exceed the MCL of 250mg/L (Mirecki, 2004). High sulfate concentration can be toxic as it enhances mercury methylation. However, in the absence of dissolved oxygen (DO) further away from the recharge well, microbial sulfate reduction reduces sulfate concentration, minimizing mercury methylation. DO concentration decreases further away from the well, especially if the aquifer has oxidable materials and anaerobic bacteria. Introduction of high DO water may release trace metals, such as Fe and As via oxidation of pyrite. Reduction of nitrate by electron donors, such as organic matter, $\mathrm{Fe}^{+2}$ or hydrogen sulfide, is observed in ASR systems recharged with reclaimed water (Pavelic et al., 2007). Further away from the injection well, mineral dissolution and ion exchange can be dominant processes (Greskowiak, 2006).

Besides health effects, changes in water quality can cause aquifer clogging and lower its productivity. During reclaimed water ASR, clogging arises from filtration of injected 
particulate matter and the growth of bacterial populations in the media. Pavelic et al. (2007) investigated the rates of clogging due to injection of tertiary treated reclaimed water in South Australia and found that clogging rate depended on turbidity, total nitrogen content and $p H$.

\subsubsection{Mechanisms of arsenic mobilization}

Naturally, As primarily exists as arsenopyrite and as a constituent in several other sulfide minerals (Garelick et al., 2008). As a metalloid, arsenic exists in many oxidation states, most commonly in the reduced state of As (III) and the oxidized state of As (V). Depending on $p H$ and oxidation potential (Eh), some species of As are dominant over others. Arsenates $\left(\mathrm{H}_{3} \mathrm{AsO}_{4}, \mathrm{H}_{2} \mathrm{AsO}_{4}{ }^{-}, \mathrm{HAsO}_{4}{ }^{2-}\right.$ and $\left.\mathrm{AsO}_{4}{ }^{3-}\right)$ are stable at high $E$ h values of oxygenated waters and arsenite species $\left(\mathrm{H}_{3} \mathrm{AsO}_{3}, \mathrm{H}_{2} \mathrm{AsO}_{3}{ }^{-}, \mathrm{HAsO}_{3}{ }^{2-)}\right.$ occur at reducing conditions with low Eh values. Pure arsenic metal is stable at very low Eh values. In the presence of oxygen, arsenite is oxidized to arsenate. At a neutral $p H$, this oxidation is very slow but proceeds faster in strongly alkaline or acidic solutions. Arsenic-sulfides, arsenic-rich pyrite and arsenic-rich iron oxyhydroxides are the most commonly found natural sources of arsenic contamination in groundwater worldwide. The primary sources of As in groundwater derive from dissolution of arsenic-bearing sulfide minerals, leaching of As from sulfides by carbonate and dissolution or reductive desorption of arsenic-rich iron oxides. Microbial mediation in the reductive dissolution of arsenic-bearing hydrated ferric oxides has also been identified as a mechanism of groundwater contamination. On a local scale, anion competitions may also enhance

mobilization. In general, the distribution of As species is consistent with equilibrium thermodynamics, such that arsenate dominates in more oxidizing waters near the recharge 
area, and arsenite predominates in the progressively reducing groundwater beyond the recharge area (Vanderzalm et al., 2011). The mechanisms of As release may be summarized as (Vanderzalm et al., 2011):

a) Oxidation of reduced As-bearing minerals, such as arsenian pyrite

b) Reductive dissolution of iron oxyhydroxide and the associated release of adsorbed As

c) Ligand exchange from sorption sites

d) Desorption following the reduction of As (V) to As (III).

Mobilization of As species during ASR in the UFA is influenced by pyrite oxidation. Pyrite is the dominant As-bearing phase in central and Southwest Florida. In these areas, pyrite contains between 100 and 11,200 ppm of As. Pyrite is generally stable under reducing conditions within $p H$ of 4 to 9 and $E h$ of 0.4 to 0.1 (Pichler et al., 2011). During ASR, pyrite is oxidized by the recharge water and can lead to the mobilization of As. Mirecki (Mirecki, 2006) used inverse geochemical modeling to identify the mechanism of As mobilization in ASR cycle tests in Southwest Florida. Besides hydrous ferric oxide (HFO) dissolution, transformation of As (V) to As (III) leads to limited sorption and enhanced arsenic mobility (Mirecki, 2006). Displacement of arsenic by competing anions is an additional possible release mechanism (Wallis et al., 2011).

\section{References}

Antoniou, E., van Breukelen, B. and Stuyfzand, P. (2015). Optimizing aquifer storage and recovery performance through reactive transport modeling. Appl. Geochem., 61; 29-40. 
Appelo, C.A.J. and Postma, D. (2010). Geochemistry, Groundwater and Pollution. Amsterdam, The Netherlands. Taylor \& Francis.

Appelo, C. (1994). Cation and proton exchange, $\mathrm{pH}$ variations, and carbonate reactions in a freshening aquifer. Water Resour. Res. 30(10); 2793-2805.

Appelo, C.A.J. and Rolle, M. (2010). PHT3D: A Reactive Multicomponent Transport Model for Saturated Porous Media. Ground Water 48; 627p.

Arthur, J.D. and Cowart, J.B. (2001). Florida aquifer storage and recovery geochemical study: Year three progress report. Florida Geological Survey open file report 83.

Barlow, P.M. and Reichard, E.G. (2010). Saltwater intrusion in coastal regions of North America. Hydrogeol. J. 18; 247-260.

Bear, J., Cheng, A.H.D., Sorek, S., Ouazar, D. and Herrera, I. (1999). Seawater Intrusion in Coastal Aquifers - Concepts, Methods and Practices. The Netherlands: Kluwer Academic Publishers.

Bethke, C.M. (2007). Geochemical and Biogeochemical Reaction Modeling. : Cambridge University Press.

Bradner, A., McPherson, B.F., Miller, R.L., Kish, G. and Bernard, B. (2005). Quality of Ground Water in the Biscayne Aquifer in Miami-Dade, Broward, and Palm Beach Counties, Florida, 1996-1998, with Emphasis on Contaminants. US Geol. Surv. Open-File Rep. 2004-1438.

Brown, C.J., Hatfield, K. and Newman, M. (2006). Lessons learned from a review of 50 ASR projects from the United States, England, Australia, India and Africa. University of North Florida.

Dillon, P., Pavelic, P., Toze, S., Rinck-Pfeiffer, S., Martin, R., Knapton, A. and Pidsley, D. (2006). Role of aquifer storage in water reuse. Desalination, 188; 123-134.

Du, X., Wang, Z. and Ye, X. (2013). Potential Clogging and Dissolution Effects During Artificial Recharge of Groundwater Using Potable Water. Water Resour. Manage. 27(10); 3573-3583.

Dzombak, D. and Morel, F. (1990). Surface complexation modeling: Hydrous ferric oxide. John Wiley \& Sons.

Fish, J.E. and Stewart, M.T. (1991). Hydrogeology of the surficial aquifer system, Dade County, Florida. US Geol. Surv. Water Resour. Invest. Rep. 90-4108. 
Florida Department of Environmental Protection (2011). Aquifer Storage and Recovery Geochemical Studies, Florida Geological Survey - Applied Geoscience Services Section.

http://www.dep.state.fl.us/geology/programs/hydrogeology/aquifer_storage.htm last accessed October 10, 2014.

Garelick, H., Jones, H., Dybowska, A. and Valsami-Jones, E. (2008). Arsenic pollution sources. Rev. Environ. Contam. Toxicol., 19; 17-60.

Geibel, N.M. and Brown, C.J. (2012). Hydraulic Fracturing of the Floridan Aquifer from Aquifer Storage and Recovery Operations. Environmental \& Engineering Geoscience, 18; 175-189.

Greskowiak, J. (2006). Reactive transport processes in artificially recharged aquifersField and modelling studies, HU Berlin.

Herczeg, A.L., Rattray, K.J., Dillon, P.J., Pavelic, P. and Barry, K.E. (2004). Geochemical processes during five years of aquifer storage recovery. Ground Water, 42; 438-445.

Maliva, R.G., Guo, W. and Missimer, T. (2007). Vertical migration of municipal wastewater in deep injection well systems, South Florida, USA. Hydrogeol. J., 15; 1387-1396.

Marella, R.L. (2009). Water withdrawals, use, and trends in Florida, 2005. US Geol. Surv. Scient. Invest. Rep. 2009-5125.

Mirecki, J.E. (2006). Geochemical Models of Water-Quality Changes During Aquifer Storage Recovery (ASR) Cycle Tests, Phase I: Geochemical Models Using Existing Data. ERDC Technical Report ERDC/EL TR-06-8.

Mirecki, J.E. (2004). Water-Quality Changes During Cycle Tests at Aquifer Storage Recovery (ASR) Systems of South Florida. U. S. Army Engineer Research and Development Center ERDC/ELTR-04-8.

Mirecki, J.E., Bennett, M.W. and López-Baláez, M.C. (2012). Arsenic Control During Aquifer Storage Recovery Cycle Tests in the Floridan Aquifer. Ground Water, 51; 539-549.

Parkhurst, D.L. and Appelo, C. (1999). User's guide to PHREEQC (Version 2): A computer program for speciation, batch-reaction, one-dimensional transport, and inverse geochemical calculations. US Geol. Surv. Water Resour. Invest. Rep. 994259. 
Pavelic, P., Dillon, P.J., Barry, K.E., Vanderzalm, J.L., Correll, R.L. and Rinck-Pfeiffer, S.M. (2007). Water quality effects on clogging rates during reclaimed water ASR in a carbonate aquifer. Journal of Hydrology, 334; 1-16.

Peters, C.J. (2008). Saltwater Intrusion Monitoring in the Biscayne Aquifer near Florida City, Miami-Dade County, Florida: 1996-2007. Proceedings of 20 ${ }^{\text {th }}$ SWIM; 195-198.

Pichler, T., Price, R., Lazareva, O. and Dippold, A. (2011). Determination of arsenic concentration and distribution in the Floridan Aquifer System. J. Geochem. Explor., 111(3); 84-96.

Prinos, S.T., Wacker, M.A., Cunningham, K.J. and Fitterman, D.V. (2014). Origins and Delineation of Saltwater Intrusion in the Biscayne Aquifer and Changes in the Distribution of Saltwater in Miami-Dade County, Florida. US Geol. Surv. Scient. Invest. Rep. 2014-5025.

Pulido-Leboeuf, P. (2004). Seawater intrusion and associated processes in a small coastal complex aquifer (Castell de Ferro, Spain). Appl. Geochem., 19; 1517-1527.

Pyne, R.D.G. (1995). Groundwater Recharge through Wells: A Guide to Aquifer Storage Recovery. Boca Raton, Florida: Lewis Publishers.

Reese, R.S. and Alvarez-Zarikian, C.A. (2007). Hydrogeology and aquifer storage and recovery performance in the Upper Floridan Aquifer, Southern Florida. Scientific Investigations Report 2006-5239.

Renken, R., Cunningham, K., Zygnerski, M., Wacker, M., Shapiro, A., Harvey, R., Metge, D., Osborn, C. and Ryan, J. (2005). Assessing the vulnerability of a municipal wellfield to contamination in a karst aquifer. Environ. Eng. Geosci., 11(4); 319-331.

Renken, R.A., Cunningham, K.J., Shapiro, A.M., Harvey, R.W., Zygnerski, M.R., Metge, D.W. and Wacker, M.A. (2008). Pathogen and chemical transport in the karst limestone of the Biscayne Aquifer: 1. Revised conceptualization of groundwater flow. Water Resour. Res., 44(88).

Rezaei, M., Sanz, E., Raeisi, E., Ayora, C., Vázquez-Suñé, E. and Carrera, J. (2005). Reactive transport modeling of calcite dissolution in the fresh-salt water mixing zone. J. Hydrol., 311; 282-298.

Sanford, W.E. and Konikow, L.F. (1989). Simulation of calcite dissolution and porosity changes in saltwater mixing zones in coastal aquifers. Water Resour. Res., 25; 655667. 
Solomon, D.K., Cole, E. and Leising, J.F. (2011). Excess air during aquifer storage and recovery in an arid basin (Las Vegas Valley, USA). Hydrogeol. J., 19; 187-194.

Sonenshein, R.S. (1997). Delineation and extent of saltwater intrusion in the Biscayne Aquifer, eastern Dade County, Florida, 1995. US Geol. Surv. Water Resour. Invest. Rep. 96-4285.

Vanderzalm, J., Dillon, P., Barry, K., Miotlinski, K., Kirby, J. and Le Gal La Salle, Corinne (2011). Arsenic mobility and impact on recovered water quality during aquifer storage and recovery using reclaimed water in a carbonate aquifer. Appl. Geochem., 26(12); 1946-1955.

Vanderzalm, J., Le Gal La Salle, C and Dillon, P. (2006). Fate of organic matter during aquifer storage and recovery (ASR) of reclaimed water in a carbonate aquifer. Appl. Geochem., 21(7); 1204-1215.

Wallis, I., Prommer, H., Pichler, T., Post, V., B. Norton, S., Annable, M.D. and Simmons, C.T. (2011). Process-based reactive transport model to quantify arsenic mobility during aquifer storage and recovery of potable water. Environ. Sci. Technol., 45(16); 6924-6931.

Werner, A.D., Bakker, M., Post, V.E., Vandenbohede, A., Lu, C., Ataie-Ashtiani, B., Simmons, C.T. and Barry, D.A. (2013). Seawater intrusion processes, investigation and management: Recent advances and future challenges. Adv. Water Resour., 51; 3-26.

Wigley, T. and Plummer, L. (1976). Mixing of carbonate waters. Geochim. Cosmochim. Acta, 40(9); 989-995.

Zhu, C. (2002a). Environmental Applications of Geochemical Modeling. Cambridge University Press.

Zhu, C., Hu, F.Q. and Burden, D.S. (2001). Multi-component reactive transport modeling of natural attenuation of an acid groundwater plume at a uranium mill tailings site. J. Contam. Hydrol., 52(1), 85-108. 


\section{RESEARCH OBJECTIVES AND APPROACH}

\subsection{Research objectives}

The research objectives of this dissertation are to identify water quality changes with respect to major ions (i.e., cations and anions) and National Drinking Water Standardregulated inorganic trace elements (As, Fe and U.), which have important implications in water supply management. These changes will be modeled for the Biscayne Aquifer due to saltwater intrusion, enhanced by sea level rise. As an adaptation to saline intrusion, water supply augmentation by ASR techniques is also considered. Modeling changes in concentrations of the inorganic elements during ASR operations using different water sources (stormwater, treated surface water, water from Lake Belt 'ponds' etc.) is the second aim of this research. The third objective is to develop a simulation-optimization model so that optimum location of wells and their pumping rates can be selected. The last objective seeks to minimize salt concentration in the Biscayne Aquifer by implementing a combination of abstraction and recharge wells and desalination of saline water. The research objectives can be summarized as follows:

a) To quantify changes in concentrations of inorganic, regulated elements, during saline intrusion and adaptation scenarios in the Biscayne Aquifer

b) To develop a reactive transport model to assess fate and transport of regulated trace metals (As and Fe) during ASR operations in South Florida.

c) To implement an optimization model and suggest cost-effective, sustainable withdrawal and injection rates to control saltwater intrusion in the Biscayne Aquifer. 
A thorough literature review was conducted to acquire and evaluate geochemical data linked to SWI and ASR in the Floridan aquifers. These dataset included constituent concentrations, $\mathrm{pH}$, alkalinity and temperature data, among others, from SWI areas in the Biscayne Aquifer (Prinos et al., 2014). Similar dataset were compiled for each cycle of the ASR at the Kissimmee River ASR pilot (Mirecki et al., 2012). The ASR site was selected because it had a comprehensive list of ions in each cycle test and perhaps provides the most complete dataset for ASR tests. The observed dataset were used to calibrate and validate conceptual groundwater models giving insight into geochemical reactions and expected water quality. Mixing models employing the PHREEQC (Parkhurst and Appelo, 2013) geochemical code were used to identify important hydrogeochemical changes during saltwater intrusion. Like most operational and testing ASR sites in South Florida, KRASR uses the UFA as its storage zone. A hydrogeochemical analysis of native water in the UFA was carried out based on data obtained from a number of monitoring wells in Southeast Florida (see chapter 5). To model water quality evolution during operation of the KRASR, a conceptual reactive transport model was developed and tested using PHAST (Parkhurst et al., 2004). PEST, a model independent optimization code, was linked to PHAST to calibrate the reactive transport model by adjusting hydrogeological properties of the UFA to fit observed ion concentrations. The calibrated model was then used to make predictive analyses of the fate of major ions and trace metals during ASR.

Management of saltwater intrusion in the Biscayne Aquifer is proposed by using a combination of abstraction and recharge wells. In this method, saline water is abstracted and desalinated; part of the desalinated water is used for municipal purposes while the 
remaining is used to recharge the aquifer. A linked simulation-optimization model was used to optimize the management process which seeks for the most effective combination of well locations and recharge/abstraction rates that minimize both total salt in the aquifer and total cost of management. A variable-density code, SEAWAT (Guo and Langevin, 2002), was used to simulate solute transport and DEAP (Fortin et al., 2012) was used for multi-objective optimization. In linked-simulation optimization, the optimization code repeatedly calls the simulation code. A python script employing FloPy (Baker et al., 2015) and DEAP was written to run the model and to do the multi-objective optimization. FloPy is a set of python modules that can be used to run MODFLOW (Harbaugh et al., 2000) and SEAWAT, among others.

\subsection{Description of modeling tools used}

PHREEQC is one of the best-documented and maintained geochemical reactions modeling programs provided by the US Geological Survey (USGS) (Parkhurst and Appelo, 2013). It is used to perform low-temperature, aqueous geochemical calculations and has the capabilities of speciation and saturation-index calculations, batch reaction and one-dimensional transport, as well as inverse modeling capabilities. As a speciation

program, PHREEQC is used to calculate saturation indices and the distribution of aqueous species. Analytical data for mole balances can be specified for any valence states of an element and distribution of redox elements among the different valence states can be determined based on specified $p E$ or any redox couple. The concentration of an element can also be adjusted to obtain equilibrium with a specified phase. In batch reaction calculations, both equilibrium and non-equilibrium reactions can be modeled. In an equilibrium calculation, the total moles of an element are distributed among different 
phases to attain system equilibrium. Non-equilibrium reactions, such as aqueous-phase mixing can also be modeled in PHREEQC where mole balances on hydrogen and oxygen allow the calculation of $p E$ and mass of water in the aqueous phase. This in turn allows water-producing or water-consuming reactions to be modeled correctly.

The law of mass action provides a fundamental description of equilibrium in water. Considering a generalized reaction $a A+b B \Leftrightarrow c C+d D$, the distribution of species at equilibrium is governed by equation 2.1 .

$$
K=\frac{[C]^{c}[D]^{d}}{[A]^{a}[B]^{b}}
$$

$\mathrm{K}$ is the equilibrium constant and the bracketed quantities denote activities or 'effective concentrations'. PHREEQC uses the Debye-Huckel and Davies equations to calculate activity coefficients. Once the activities of free ions in solution are calculated, the saturation of a water sample can be calculated in terms of saturation index (SI) given in equation 2.2.

$$
S I=\log \left(\frac{I A P}{K}\right)
$$

IAP, ion activity product, is expressed similar to solubility product but the activities of the ions used are those in the water sample, and not necessarily in equilibrium. SI values indicate the tendency of a mineral phase towards dissolution or precipitation. For SI $=0$, there is equilibrium between the mineral and the solution, whereas SI $<0$ reflects undersaturation and SI $>0$ reflects super-saturation. To do speciation calculations in PHREEQC, water composition is input and the program then calculates the ion activities and saturation states of the relevant minerals. A solution can also be brought to 
equilibrium with a specified mineral in PHREEQC and changes in the water quality can be calculated.

In modeling ASR cycles, PHREEQC's geochemical modeling capability is exploited by coupling it to powerful models that can simulate 3D flow and transport of fluids. Models capable of simulating ASR cycles have used various combinations of PHREEQC and other transport programs, such as MODFLOW (Wallis et al., 2011), SWIFT (Gaus et al., 2002), and HST3D (Petkewich et al., 2004). In the ASR modeling of this research, PHAST (Parkhurst et al., 2004), which couples PHREEQC and HST3D, is used.

PHAST is a 3D multi-component reactive transport model and is based on the finite difference method. It has all the various reaction modeling capabilities of PHREEQC. Flow and transport simulations are based on a modified version of HST3D which is restricted to constant density flows. Therefore, the PHAST simulator does not account for density effects when injecting freshwater into a brackish aquifer during an ASR. However, PHAST may be used to simulate ASR when the salinity of brackish water does not exceed 5,000 mg/L (Parkhurst et al., 2004), which is the threshold for buoyancy stratification. Reactive transport models generally require large amounts of memory and processing times. In PHAST, chemical reaction computations are the most computationally intensive. To reduce processing times, PHAST can be run in parallel mode on multiple computers in a network.

SEAWAT couples MODFLOW and a multi-component transport program, MT3DMS (Zheng and Wang, 1999). This program is capable of simulating variabledensity flows which is especially important in modeling saltwater intrusion. SEAWAT has been successfully used for saltwater movement studies in South Florida (Dausman 
and Langevin, 2005; Langevin, 2001; Langevin and Guo, 2006; Langevin and Zygnerski, 2013); and it has also been used in this dissertation for simulation of saltwater management.

\section{References}

Baker, M., Post, V., Langevin, C., Hughes, J., White, J., Frances, A., Fienen, M. and Starn, J. (2015). FloPy3: a Python package to create, run, and post-process MODFLOW-based models. GitHub repository, https://github.com/modflowpy/flopy.

Dausman, A. and Langevin, C.D. (2005). Movement of the saltwater interface in the surficial aquifer system in response to hydrologic stresses and water-management practices, Broward County, Florida. US Geol. Surv. Scient. Invest. Rep. 2004-5256.

Fortin, F., Rainville, D., Gardner, M.G., Parizeau, M. and Gagné, C. (2012). DEAP: Evolutionary algorithms made easy. The Journal of Machine Learning Research, 13; 2171-2175.

Gaus, I., Shand, P., Gale, I., Williams, A. and Eastwood, J. (2002). Geochemical modelling of fluoride concentration changes during Aquifer Storage and Recovery (ASR) in the Chalk aquifer in Wessex, England. Quarterly Journal of Engineering Geology and Hydrogeology, 35(2); 203-208.

Guo, W. and Langevin, C. (2002). User's guide to SEAWAT. US Geological Survey Tech Water Resour Invest., 6-A7.

Harbaugh, A.W., Banta, E.R., Hill, M.C. and McDonald, M.G. (2000). MODFLOW2000, the US Geological Survey Modular Ground-Water Model: User Guide to Modularization Concepts and the Ground-Water Flow Process. Reston, VA: US Geological Survey Reston.

Langevin, C.D. (2001). Simulation of Ground-water discharge to Biscayne Bay, Southeastern Florida. U. S. Geological Survey Water-Resources Investigations Report 00-4251.

Langevin, C.D. and Guo, W. (2006). MODFLOW/MT3DMS-Based Simulation of Variable

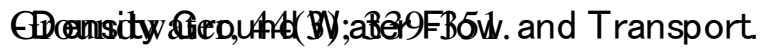

Langevin, C.D. and Zygnerski, M. (2013). Effect of Sea Level Rise on Salt Water Intrusion near a Coastal Well Field in Southeastern Florida. Groundwater, 51(5); 781-803. 
Mirecki, J.E., Bennett, M.W. and López Baláez, M.C. (2012). Arsenic Control During Aquifer Storage Recovery Cycle Tests in the Floridan Aquifer. Ground Water, 51(4); 539-549.

Parkhurst, D.L. and Appelo, C. (2013). Description of input and examples for PHREEQC version 3: a computer program for speciation, batch-reaction, one-dimensional transport, and inverse geochemical calculations. US Geol. Surv. Techniques and Methods, book 6, chap. A-43.

Parkhurst, D.L., Kipp, K.L., Engesgaard, P. and Charlton, S.R. (2004). PHAST--A Program for Simulating Ground-Water Flow, Solute Transport, and Multicomponent Geochemical Reactions. : US Department of the Interior, US Geological Survey.

Petkewich, M.D., Parkhurst, D.L., Conlon, K.J., Campbell, B.G. and Mirecki, J.E. (2004). Hydrologic and Geochemical Evaluation of Aquifer Storage Recovery in the Santee Limestone/Black Mingo Aquifer, Charleston, South Carolina, 1998-2002. : US Department of the Interior, US Geological Survey.

Prinos, S.T., Wacker, M.A., Cunningham, K.J. and Fitterman, D.V. (2014). Origins and Delineation of Saltwater Intrusion in the Biscayne Aquifer and Changes in the Distribution of Saltwater in Miami-Dade County, Florida. US Geol. Surv. Scient. Invest. Rep. 2014-5025.

Wallis, I., Prommer, H., Pichler, T., Post, V., B. Norton, S., Annable, M.D. and Simmons, C.T. (2011). Process-based reactive transport model to quantify arsenic mobility during aquifer storage and recovery of potable water. Environ. Sci. Technol., 45(1); 6924-6931.

Zheng, C. and Wang, P.P. (1999). MT3DMS: A modular three-dimensional multispecies transport model for simulation of advection, dispersion, and chemical reactions of contaminants in groundwater systems; documentation and user's guide, Alabama University. 


\section{HYDRODGEOCHEMICAL ANALYSIS OF PROCESSES THROUGH MODELING OF SALTWATER INTRUSION IMPACTS IN BISCAYNE AQUIFER WATER QUALITY}

(Published in Aquatic Geochemistry)

\subsection{Abstract}

Hydrogeochemical processes that accompany seawater intrusion in coastal aquifers can alter the resulting water quality and are important ingredients in coastal aquifer management. The presence of dissolution-precipitation reactions and ion exchange in the mixing zone of the Biscayne Aquifer (Florida, USA) are suggested based on changes in major ion concentrations and mineral saturation indices (SI). Major ion concentrations from 11 groundwater samples are compared with theoretical mixing between freshwater and seawater. PHREEQC code was used to calculate saturation indices of the samples with respect to common phases in the Biscayne Aquifer. High $\mathrm{Ca}^{2+}$ and $\mathrm{HCO}_{3}{ }^{-}$content of the samples is typical of waters in contact with carbonate aquifers. Water quality of the samples is mainly attributed to mixing and precipitationdissolution reactions with calcite and dolomite. The samples were saturated with calcite (SI $\sim 0$ ) and unsaturated for dolomite $(\mathrm{SI}<0)$ while a few samples showed dolomite saturation. Because gypsum and halite SI could be predicted by theoretical mixing, reactions with those minerals, if present, are thought to be insignificant. In the activeintrusion areas, cation exchange also appears to modify water quality leading to excess $\mathrm{Ca}^{2+}$, but depleted $\mathrm{Na}^{+}, \mathrm{Mg}^{2+}$ and $\mathrm{K}^{+}$concentrations. On the other hand, samples from previous-intrusion areas plotted very close to the theoretical mixing line and approached equilibrium with the seawater. 


\subsection{Introduction}

The Biscayne Aquifer is a primary source of water supply in Southeast Florida, including Miami-Dade, Broward and southeastern parts of Palm Beach County. It also serves the Florida Keys, which pump water from the mainland in south west MiamiDade. Serving the public water supply needs of more than 4 million people (Marella, 2009), the Biscayne Aquifer has been designated a sole-source aquifer by the U.S. Environmental Protection Agency (EPA). Miami-Dade County, with a population of more than 2.5 million, withdrew about 490 MGD of groundwater in 2005 and ninety-nine percent of the withdrawal originated from the Biscayne Aquifer (Marella, 2009). Bordered to the east and south by sources of saltwater in the Atlantic Ocean, Biscayne Bay, and Florida Bay, the Biscayne Aquifer is prone to saltwater intrusion (SWI). SWI has been an issue of concern in Southeastern Florida since the 1930s, when a large part of the Everglades was drained by a network of canals to provide land for urban development, flood control and agriculture. Before development, some water flowed from the Everglades towards the Atlantic Ocean and the Florida Bay, but this natural flow was altered with the construction of the network of canals. Drainage resulted in progressive inland migration of the saltwater interface, increasing the risk of wellfield contamination by saline groundwater. Beginning in 1946, the canals were gated and control structures were built to decrease inland flow of saltwater from the ocean (Barlow and Reichard, 2010). Besides drainage, harsh droughts and changes in wellfield operations have contributed to salt water intrusion in Southeast Florida (Sonenshein, 1997). Climate change and rising sea levels would also exacerbate SWI by changing the hydraulic gradient and favoring inland flow of seawater. 
A hydrogeochemical study of SWI in the Biscayne Aquifer is very important to understand prevailing processes and resulting changes in water quality as well as hydrogeological characteristics. Changes in position of the saltwater front and the mechanisms of intrusion in the Biscayne Aquifer have been documented by a number of studies (Cooper et al., 1964; Dausman and Langevin, 2005; Kohout, 1960; Langevin and Zygnerski, 2013; Peters, 2008; Sonenshein, 1997). The U.S. Geological Survey (USGS) mapped the approximate inland extent of saltwater intrusion in the Biscayne Aquifer in 1978 (Swayze, 1980), 1984 (Klein and Waller, 1984), 1995 (Sonenshein, 1997) and more recently in 2011 (Prinos et al., 2014). Extensive salinity and water level data are regularly collected from monitoring wells and are published online at the USGS National Water Information System (NWIS) web (http://maps.waterdata.usgs.gov/mapper/index.html). However, only a few of the wells include major-ion data and limited research has addressed hydrogeochemical changes in the mixing zone. The objective of this study is to evaluate if ion exchange and dissolution-precipitation reactions affect major ions in the mixing zone of the Biscayne Aquifer.

\subsection{Hydrogeochemistry of the Biscayne Aquifer}

The surficial aquifer system in South Florida consists of Miocene and Holocene age siliclastic and carbonate sediments and varies in thickness between $50 \mathrm{~m}$ and $82 \mathrm{~m}$ (Fish and Stewart, 1991; Reese and Cunningham, 2000). The Biscayne Aquifer forms the top of the surficial aquifer system and is mainly described as an unconfined aquifer (Bradner et al., 2005; Renken et al., 2008). Permeable groundwater flow zones within the aquifer, however, appear to be semi-confined in some areas (Renken et al., 2005). The Biscayne Aquifer is 17 to $30 \mathrm{~m}$ thick in South Miami-Dade and gets thicker towards the coast. At 
its deepest location in northeastern Miami-Dade County, it is approximately $55 \mathrm{~m}$ thick (Prinos et al., 2014). The Biscayne Aquifer is one of the most productive karst aquifers with transmissivity values ranging between 0.4 and $3.1 \mathrm{~m}^{2} / \mathrm{s}$ (Fish and Stewart, 1991; Renken et al., 2008). The karstic limestone has a highly heterogeneous and anisotropic distribution of porosity and permeability (Cunningham, 2004; Cunningham et al., 2006).The aquifer is comprised, from top to bottom, of Pamlico Sand, Miami Oolite, Anastasia Formation, Key Largo Limestone, Fort Thompson Formation and the Tamiami Formation (Bradner et al., 2005). The Pamlico Sand is fine to medium-grained quartz; the Oolites are commonly filled with lime mud and sand; the Anastasia Formation consists of shelly limestone and shelly sandstone; the Key Largo Limestone is very porous coralline limestone; and the Tamiami Formation consists of limestone, calcareous sand stone and sand. Thus the aquifer is chiefly made of limestone, dolomite, sand, clay and shells (Bradner et al., 2005).

Besides mixing between freshwater and saltwater, dissolution-precipitation of minerals and ion exchange, among others, may simultaneously affect water quality of the mixing zone. Valuable information on these processes can be obtained by analyzing the deviation, from the theoretical mixing line (i.e., calculated from seawater fraction in the mixture as shown in section 3), of the chemical composition of the groundwater (Appelo and Postma, 2010; Appelo, 1994; Bear et al., 1999; Ghiglieri et al., 2012; Gimenez and Morell, 1997; Kouzana et al., 2009; Price and Herman, 1991; Russak and Sivan, 2010). In theoretical mixing, freshwater and saltwater are the end members and other mixed solutions have component concentrations that are between those in the end members. 
Theoretical mixing lines are only appropriate for conservative constituents and deviations from the theoretical mixing imply the presence of geochemical reactions.

Carbonate dissolution can occur in a mixing zone even though both the freshwater and saltwater end-members are saturated with carbonates (Appelo and Postma, 2010; Rezaei et al., 2005; Sanford and Konikow, 1989; Werner et al., 2013; Wigley and Plummer, 1976). The reason both over and under saturation may occur in mixing zones is due mainly to interplay of ionic strength and mixing, which oppose each other (Rezaei et al., 2005). An increase in ionic strength increases solubility and the increase in solubility is more marked for low salinities than for high salinities. These effects, combined with changes in speciation, make prediction of calcite over- or undersaturation a not-so-trivial analysis (Werner et al., 2013). Some observations report dissolution of calcite in mixing zones (Back et al., 1986; Rezaei et al., 2005; Romanov and Dreybrodt, 2006; Sanford and Konikow, 1989; Sanz et al., 2011; Sivan et al., 2005; Smart et al., 1988; Stoessell et al., 1989; Werner et al., 2013), while others report absence of dissolution (Plummer et al., 1976; Price and Herman, 1991; Pulido-Leboeuf, 2004; Wicks et al., 1995). Cation exchange in mixing zones of clastic sediments has been discussed in detail in Appelo (1994) and Appelo and Postma (2010) where the exchange is mainly between $\mathrm{Na}^{+}$and $\mathrm{Ca}^{2+}$. In the karstic Biscayne Aquifer, cation exchange may not be significant due to low clay content but some exchange can occur on the limited clay and dissolved organic matter, which is found in the aquifer (Harvey et al., 2008). Oxidation-reduction is not suspected to cause significant changes in major ion concentrations in comparison to either ion exchange or dissolution-precipitation reactions; although it may be significant in the speciation of trace metals. 
Understanding the processes is vital because they are crucial in model development and application, affect the resulting water quality and are relevant in the selection of most appropriate methods that may be required for water supply treatment. In addition, understanding the processes gives insight into what might happen with increased intrusion due to sea level rise from climate change and enables forecasting in support of adaptation strategies. The study area extends 8 to $11 \mathrm{Km}$ inland from the coast or Biscayne Bay. It is primarily the eastern part of Miami-Dade County, bounded by Hallandale Beach in the north and by the Florida Bay in the south. The study area and locations of the wells used in this study are shown in Figure 3.1. 


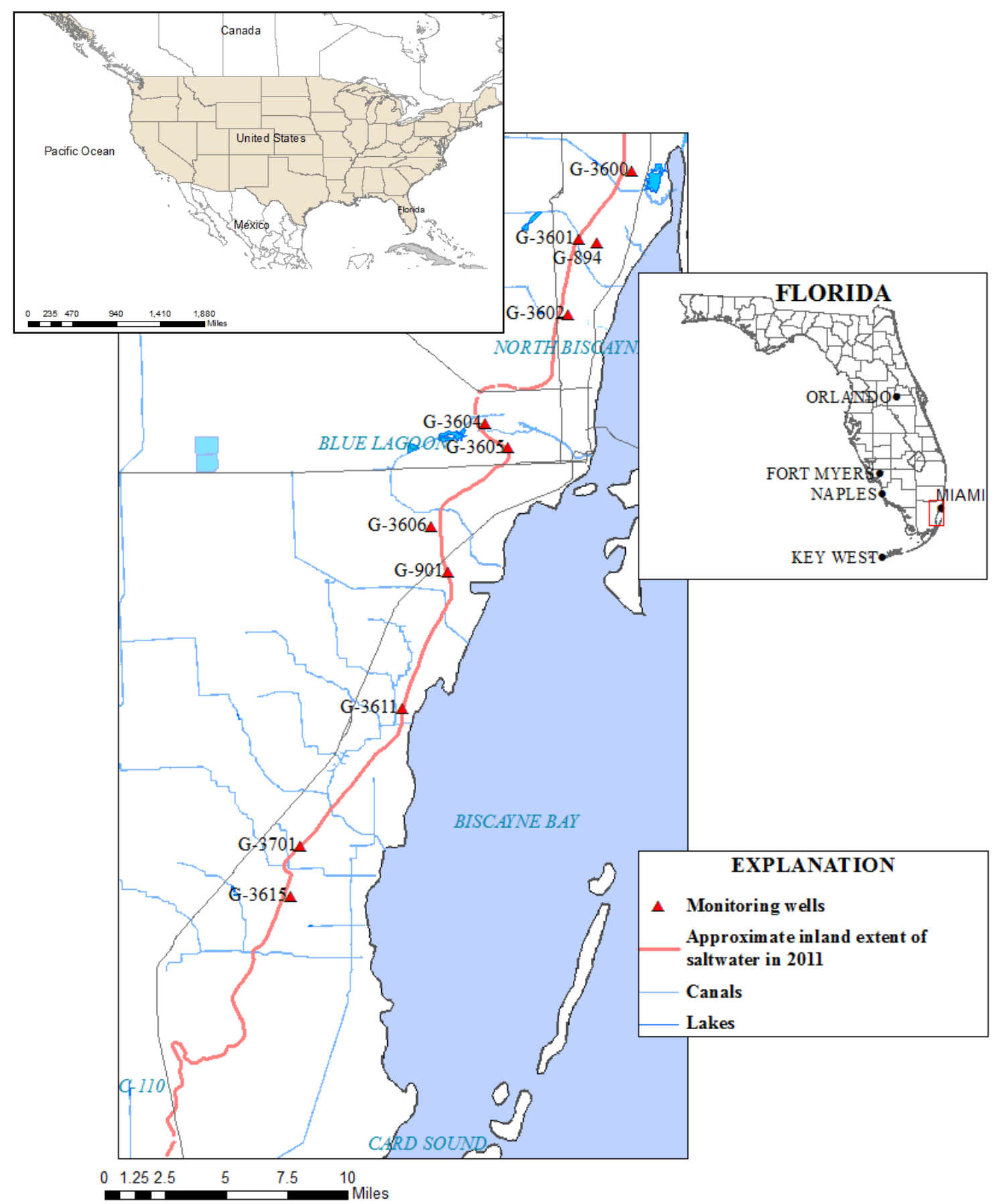

Figure 3.1 Location of monitoring wells used in the study and the approximate inland extent of saltwater, representing the $1000 \mathrm{mg} / \mathrm{L}$ isochlor, in 2011 (Prinos et al, 2014). Base maps are from South Florida Water Management District, Miami-Dade County, USGS and ESRI digital data. 


\subsection{Methods}

Groundwater samples were compiled from Prinos et al. (2014) who reported a total of 52 groundwater samples that were collected from 34 monitoring wells using a submersible pump, suction pump or Kemmerer water sampler. Most of the monitoring wells had upper casings 2-inches in diameter and were designed such that the bottom would be at the base of the Biscayne Aquifer. The well depths ranged from 23.2 to 61 meters with G-3600, G-3601 and G-3602 being among the deepest wells sampled. The wells selected for our analysis were sampled from discrete intervals of about $1.5 \mathrm{~m}$ (Table 3.1) and the bottom of the intervals generally coincided with the well depth (i.e., the base of the Biscayne Aquifer). Only samples collected between the months of July and September of 2010 were used in the analysis. Thus, the samples were spatially and temporally constrained to allow reasonable comparison of the geochemical processes in the mixing zone. Monitoring wells within $8.5 \mathrm{Km}$ of Turkey Point Nuclear Power Plant's cooling canal system may be affected by hyper saline water from the cooling canals (Prinos et al., 2014) and have not been included in this analysis. Samples that showed constituents that are found in sewage effluents were also excluded from the analysis. An impermeable confining unit underlying the Biscayne Aquifer prevents contamination from lower aquifers and any relict saltwater is believed to have been flushed from the aquifer (Prinos et al., 2014). The selected water samples are therefore expected to result solely from mixing between freshwater and saltwater and water-rock interactions. Sampling procedures followed the USGS National Field Manual for collection of water-quality data and major ions were analyzed at the USGS National 
Water Quality Laboratory in Denver, Colorado. Water quality of the selected wells is shown in Table 3.1. Ion-analysis errors of all the samples are less than 5\%. 
Table 3.1 Water quality of wells selected in the study ${ }^{\dagger}$

\begin{tabular}{|c|c|c|c|c|c|c|c|c|c|c|c|c|}
\hline Sample & $\begin{array}{l}\text { Well } \\
\text { Depth } \\
(\mathrm{m})\end{array}$ & $\begin{array}{l}\text { Sample } \\
\text { Interval } \\
(\mathrm{m})\end{array}$ & $\begin{array}{l}\text { Temperature } \\
{ }^{\circ} \mathrm{C} \\
\end{array}$ & $\begin{array}{l}\mathrm{pH} \\
\text { Units }\end{array}$ & $\begin{array}{l}\mathrm{Ca}^{2+} \\
\mathrm{mg} / \mathrm{L}\end{array}$ & $\mathrm{Mg}^{2+}$ & $\mathrm{Na}^{+}$ & $\mathrm{K}^{+}$ & $\mathrm{Cl}^{-}$ & $\mathrm{SO}_{4}{ }^{2-}$ & $\begin{array}{l}\text { Alkalinity } \\
\text { as } \mathrm{CaCO}_{3}\end{array}$ & \% SW \\
\hline G-3606 & 36.6 & 1.5 & 26.0 & 6.99 & 104 & 2.7 & 25.7 & 1.03 & 36.3 & 19.4 & 238 & 0.0 \\
\hline G-894 & 23.2 & 0.5 & 25.8 & 7.25 & 80 & 2.7 & 13 & 1.21 & 18.4 & 28.8 & 165 & 0.1 \\
\hline G-3600 & 61.0 & 1.5 & 25.5 & 6.95 & 487 & 1120 & 7820 & 312 & 15400 & 1910 & 258 & 81.0 \\
\hline G-3601 & 57.9 & 1.5 & 24.6 & 6.85 & 165 & 61.4 & 676 & 16.3 & 1350 & 121 & 255 & 6.9 \\
\hline G-3602 & 48.8 & 1.5 & 25.3 & 6.90 & 264 & 199 & 1990 & 50.4 & 4050 & 423 & 256 & 21.2 \\
\hline G-3604 & 36.6 & 1.5 & 26.2 & 7.09 & 224 & 312 & 2600 & 87.9 & 5330 & 643 & 219 & 27.9 \\
\hline G-3605 & 33.5 & 1.5 & 26.7 & 6.93 & 182 & 90.5 & 955 & 26.1 & 1940 & 232 & 226 & 10.0 \\
\hline G-3611 & 30.5 & 1.5 & 25.3 & 7.08 & 97 & 4.8 & 88.3 & 2.52 & 175 & 24.2 & 192 & 0.7 \\
\hline G-3615 & 24.4 & 1.5 & 25.3 & 6.76 & 264 & 58.3 & 768 & 11.2 & 1780 & 111 & 180 & 9.2 \\
\hline G-3701 & 25.3 & 1.5 & 25.1 & 7.06 & 132 & 14.2 & 244 & 2.02 & 566 & 34.7 & 162 & 2.8 \\
\hline G-901 & 29.3 & 0.4 & 25.6 & 7.04 & 273 & 121 & 1200 & 19.2 & 2590 & 206 & 167 & 13.5 \\
\hline
\end{tabular}

† Data was extracted from Prinos et. al. (2014)

$\ddagger \%$ SW is seawater fraction in the sample calculated based on its chloride concentration 
Recharge to the Biscayne Aquifer is derived from rainfall runoff (mostly between June and September) including water that leaks downward from canals (Bradner et al., 2005). Freshwater (FW) end member is the average composition of water samples collected from canals in Miami-Dade County which were sampled simultaneously with the groundwater samples by Prinos et al. (2014). The canal samples had low total dissolved solids (chloride less than $60 \mathrm{mg} / \mathrm{l}$ ) and near neutral $\mathrm{pH}$ reflecting the composition of rainwater buffered by the aquifer limestone (Table 3.2). Seawater (SW) has average composition shown in Table 3.2 (Hem, 1985) with $\mathrm{pH}$ of 8 selected to represent the Biscayne Bay. The ion balance errors are less than 1\% in both FW and SW end members.

Table 3.2 Temperature (T) and chemical compositions of the freshwater and saltwater end members used in modeling.

\begin{tabular}{lllllllllll}
\hline & $\mathrm{T}$ & $\mathrm{pH}$ & $\mathrm{Cl}^{-}$ & $\mathrm{SO}_{4}{ }^{2-}$ & $\mathrm{Ca}^{2+}$ & $\mathrm{Na}^{+}$ & $\mathrm{Mg}^{2+}$ & $\mathrm{K}^{+}$ & $\mathrm{HCO}_{3}{ }^{-}$ & $\mathrm{pCO}_{2}$ \\
& $\left({ }^{\circ} \mathrm{C}\right)$ & & $\mathrm{mg} / \mathrm{L}$ & $\mathrm{mg} / \mathrm{L}$ & $\mathrm{mg} / \mathrm{L}$ & $\mathrm{mg} / \mathrm{L}$ & $\mathrm{mg} / \mathrm{L}$ & $\mathrm{mg} / \mathrm{L}$ & $\mathrm{mg} / \mathrm{L}$ & $(\mathrm{atm})$ \\
\hline FW & 28.5 & 7.4 & 39 & 11.6 & 75.4 & 24.9 & 5.3 & 3.6 & 234.2 & $10^{-1.69}$ \\
$\mathrm{SW}$ & 25.0 & 8.0 & 19000 & 2700 & 410 & 10500 & 1350 & 390 & 66.6 & $10^{-3.13}$ \\
\hline
\end{tabular}

Changes in major-ion concentrations $\left(\mathrm{Ca}^{2+}, \mathrm{Na}^{+}, \mathrm{Mg}^{2+}, \mathrm{K}^{+}, \mathrm{SO}_{4}{ }^{2-}\right.$ and $\left.\mathrm{HCO}_{3}{ }^{-}\right)$, ionic ratios (Ca: $\left.\left(\mathrm{HCO}_{3}{ }^{-}+\mathrm{SO}_{4}{ }^{2-}\right)\right)$ and saturation indices are used to identify the hydrochemical processes in saltwater-intruded areas. Major-ion concentrations for each of the samples were compared with ideal freshwater-saltwater mixing lines, which are functions of saltwater fraction in the mixture. Assuming chloride is conservative, the fraction of saltwater in a sample is calculated based on its chloride content: 


$$
f_{\text {sea }}=\frac{C_{C l, \text { sample }}-C_{C l, \text { fresh }}}{C_{C l, \text { sea }}-C_{C l, \text { fresh }}}
$$

where $f_{\text {sea }}$ is the seawater fraction in the mixture. $C_{C l, \text { fresh }}, C_{C l \text {,sample }}$ and $C_{C l, \text { sea }}$ are respectively the chloride contents of FW, sample water and SW. The theoretical mixing line was then calculated for each ion using the seawater fraction:

$$
C_{i, \text { mix }}=f_{\text {sea }} \cdot C_{i, \text { sea }}+\left(1-f_{\text {sea }}\right) \cdot C_{i, \text { fresh }}
$$

The excess or depleted amount of each ion (ionic delta, $\Delta C_{i}$ ) is due to water-rock interactions and is given by:

$$
\Delta C_{i}=C_{i, \text { sample }}-C_{i, \text { mix }}
$$

The geochemical model PHREEQC 3.0 (Parkhurst and Appelo, 2013) was used to calculate saturation index (SI) of the samples as well as SI for theoretical mixing between the FW and SW end members. $\mathrm{pH}$ and Alkalinity of the samples were used to constrain PHREEQC's carbonic acid system. Similar to SI, partial pressure of $\mathrm{CO}_{2}$ is a measure of its saturation and affects carbonate equilibrium. The partial pressure $P_{\mathrm{CO}_{2}}$ was calculated for each sample using Henry's law (Parkhurst and Appelo, 2013) as follows:

$$
P_{\mathrm{CO}_{2}}=10^{1.468} \cdot a_{\mathrm{CO}_{2(a q)}}
$$

where $P_{\mathrm{CO}_{2}}$ is the partial pressure (atmospheres) and $a_{\mathrm{CO}_{2(a q)}}$ is activity of $\mathrm{CO}_{2}$ in the aqueous phase. Activity of $\mathrm{CO}_{2}$ is assumed equal to its concentration, which has been measured for many of the samples. The sample partial pressure is then compared with 
that calculated by PHREEQC for theoretical mixing between the freshwater and seawater.

\subsection{Results and discussion}

\subsubsection{Piper diagram}

The Piper diagram (Figure 3.2) shows the results of chemical analyses along with the representative FW and SW end members. The samples show small deviations from the mixing line indicating that mixing dominates the processes. Most of the samples lie slightly above the theoretical mixing line and water-rock interactions, in addition to mixing, modify the water quality. Two major water types can be seen from the Piper diagram, namely a $\mathrm{Na}-\mathrm{HCO}_{3}$ type for the samples near the $\mathrm{FW}$ end member and a $\mathrm{Na}-\mathrm{Cl}$ type near the SW end member. For the purpose of this discussion, the wells are classified as 'active-intrusion', 'previous-intrusion' and 'intermediate' wells based on the molar ratio, $\mathrm{Ca}:\left(\mathrm{HCO}_{3}+\mathrm{SO}_{4}\right)$. Ratio of greater than 1 indicates active intrusion and if the ratio is less than 1 but chloride concentration is more than $1000 \mathrm{mg} / \mathrm{L}$, then the well has been previously intruded (Prinos et al., 2014) . The following wells are active intrusion wells: G-901, G-3611, G-3615 and G-3701. On the other hand, wells, G-3600, G-3601, G-3602, G-3604 and G-3605 show previous intrusion (Prinos et al., 2014). The remaining wells (G-894 and G-3606) fall under the 'intermediate’ category and have very low chloride concentrations. Well G-894 is in the intruded area and had historically high chloride concentration but isotopic compositions show that its current chemistry is dominated by recharge from precipitation (Prinos et al., 2014). All of the intruded wells (i.e., previous-intrusion and active-intrusion) plot above the theoretical mixing line and are clustered near the bottom right corner of the rhombus; the sum of $\mathrm{Na}^{+}$and $\mathrm{K}^{+}$ 
dominates the cations and the sum of $\mathrm{SO}_{4}{ }^{2-}$ and $\mathrm{Cl}^{-}$dominates the anions. Comparatively, the previously-intruded wells plot near the mixing line and they approach equilibrium.

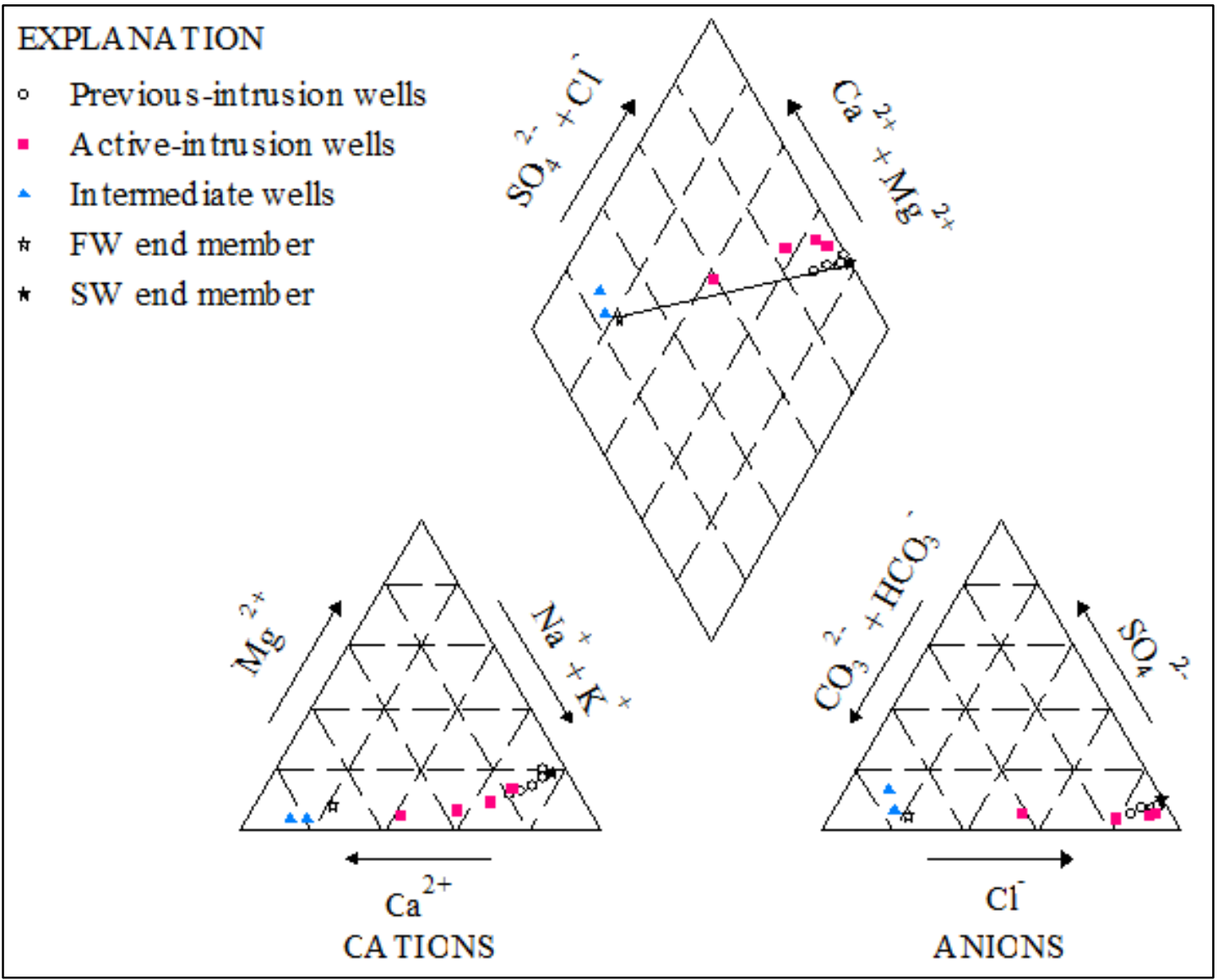

Figure 3.2 Piper diagram of the groundwater samples

\subsubsection{Saturation indices (SI)}

Calcite, dolomite, gypsum, aragonite and halite SI are calculated as functions of the proportions of seawater in the mixture (Figure 3.3). Similarly, the partial pressure of $\mathrm{CO}_{2}$ is calculated for the samples and the theoretical mixing. Calcite-supersaturated seawater is mixed with calcite-saturated freshwater and the resulting SI is non-linearly related to mixing. Sample SI values are lower than for conservative behavior, showing the nonconservative nature of calcite in the aquifer. The groundwater samples have calcite SI 
between 0.2 and -0.2 . Most of the samples have SI between -0.05 and 0.05 . Assuming uncertainty of \pm 0.05 in SI calculations of calcite (Price and Herman, 1991), many of the groundwater samples are saturated with respect to calcite without any clear distinction among the active-intrusion, intermediate and previously-intruded wells. Dolomite is supersaturated for conservative mixing ratios in excess of 5\%. Likewise, samples with more than $15 \%$ seawater are supersaturated with dolomite while those with less than $10 \%$ seawater are undersaturated. Almost all of the active-intrusion wells are under-saturated while most of the previous-intruded samples are over-saturated with dolomite. The samples are undersaturated with respect to gypsum and halite which is also expected from the theoretical mixing. Because SI values for halite and gypsum are predicted well by conservative mixing, geochemical reactions with those minerals, if present in the aquifer may not be significant. $\log P_{\mathrm{CO}_{2}}$ values of -1.69 and -3.13 are calculated for the FW and SW end members. $P_{\mathrm{CO}_{2}}$ in all the groundwater samples are one or two orders of magnitude higher than atmospheric value of $10^{-3.5}$ due to carbon dioxide uptake linked to infiltration of rainwater, root respiration of plants and decay of organic matter (Price, 2001). In comparison to simple mixing, all the samples show excess $\mathrm{CO}_{2}$. An increase in $\mathrm{CO}_{2}$ partial pressure lowers solution $\mathrm{pH}$ and can lead to calcite dissolution. It can be concluded that dissolutions of calcite and dolomite are plausible for the active intrusion and some of the previous-intrusion samples (Figure 3.3) and this is expected to result in excess $\mathrm{Ca}$ and $\mathrm{HCO}_{3}{ }^{-}$content of the samples. Previous-intrusion wells are over-saturated with dolomite when saltwater content exceeds $20 \%$. Samples with more than $50 \%$ saltwater are undersaturated for aragonite, which is also suggested by the mixing model. 

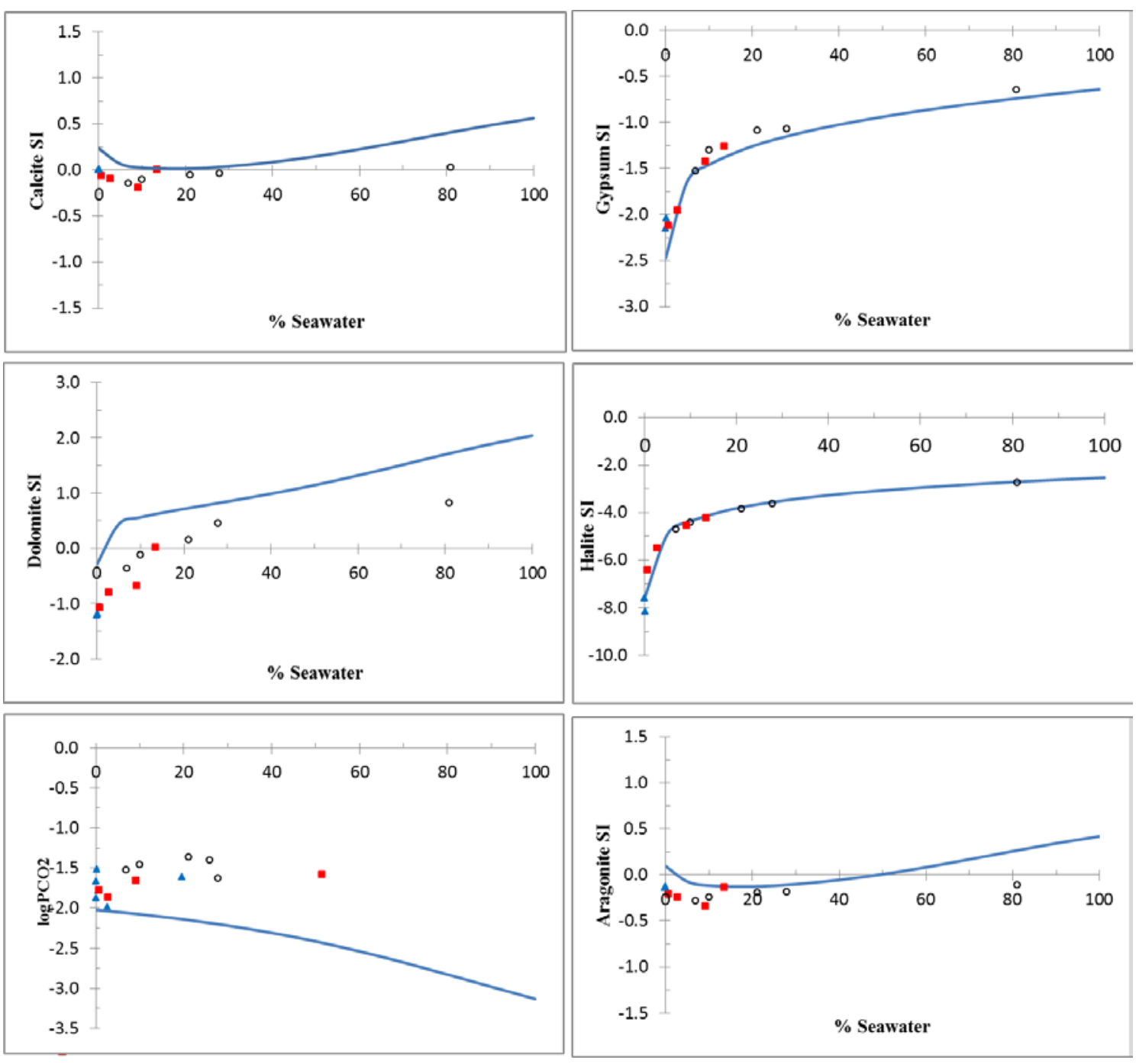

-Theoretical mixing line $\star$ Intermediate wells

Previous-intrusion wells - Active-intrusion wells

Figure 3.3 SI of the samples and theoretical mixing with respect to calcite, dolomite, gypsum, aragonite and halite. Partial pressure of $\mathrm{CO}_{2}$ in the samples, together with modeled mixing line is also shown.

\subsubsection{Ionic deltas}

Figure 3.4 shows major ion concentrations of the samples and the conservative mixing line for each ion. It is observed that $\mathrm{Na}^{+}, \mathrm{Mg}^{2+}$ and $\mathrm{K}^{+}$are depleted in the majority of the samples, whereas $\mathrm{Ca}^{2+}$ is enriched. Considering that the aquifer minerals are mainly calcite and dolomite, depletions of $\mathrm{Na}^{+}$and $\mathrm{K}^{+}$may imply the presence of cation- 
exchange reactions at the well locations. For a given percentage of seawater, larger deviations from the theoretical mixing line (ionic deltas) are witnessed for the activeintrusion wells than the previous-intrusion wells. The previous-intrusion wells, on the other hand, plot near the mix line and approach equilibrium with the mixture. While excess $\mathrm{Ca}$ and $\mathrm{HCO}_{3}{ }^{-}$result from dissolution of calcite and dolomite, some enrichment of $\mathrm{Ca}^{2+}$ and $\mathrm{HCO}_{3}{ }^{-}$can also be attributed to indirect-ion exchange which normally accompanies saltwater intrusion (Prinos et al., 2014). Depletion of $\mathrm{Mg}^{2+}$ (at \%SW < 20) can also be due to ion exchange because dolomite is predicted to be dissolving and its dissolution would tend to increase concentration of $\mathrm{Mg}^{2+}$ in the mixture.

Sample $\mathrm{HCO}_{3}{ }^{-}$frequently lie above the theoretical mixing line except for the activeintrusion samples. Some of the possible sources of $\mathrm{HCO}_{3}{ }^{-}$are dissolution of calcite and mineralization of organic matter by sulfate reduction. Calcite SI is about zero for most of the samples meaning there is equal tendency or rates of dissolution and precipitation. Thermodynamics only predicts the potential of dissolution or precipitation but in reality kinetic factors can cause the system to behave differently. Depletion of $\mathrm{HCO}_{3}$ in the active intrusion wells can be due to calcite precipitation which is probable in the mixing zone. All the intruded wells are depleted in $\mathrm{SO}_{4}{ }^{2-}$ (Figure 3.4). Gypsum appears conservative (SI predicted by mixing) and may not significantly affect $\mathrm{SO}_{4}{ }^{2-}$ concentration in the mixture. The depletion of $\mathrm{SO}_{4}{ }^{2-}$ in the wells can be because of its reduction by sulfate-reducing bacteria during anaerobic oxidation of organic matter (Sivan et al., 2005; Werner et al., 2013) 

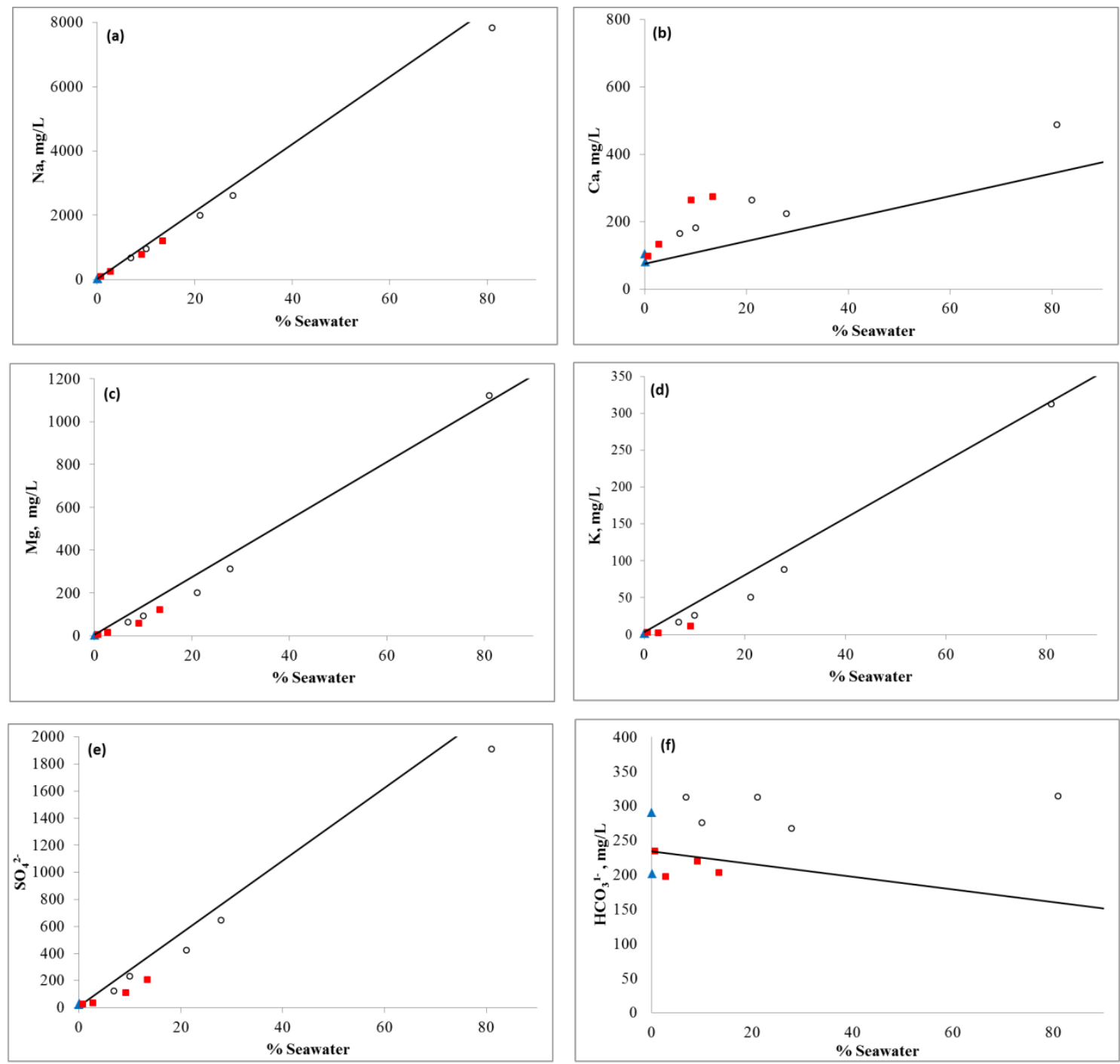

—Theoretical mixing line $\Delta$ Intermediate wells

$\circ$ Previous-intrusion wells $\quad$ Active-intrusion wells

Figure 3.4 Observed ionic concentrations and theoretical mixing lines

\subsection{Conclusions}

Groundwater quality near the saltwater front of the Biscayne Aquifer results from mixing between saltwater and freshwater, dissolution-precipitation of calcite and dolomite as well as cation exchange reactions. PHREEQC is used to estimate the saturation indices of the samples and saturation indices resulting from theoretical mixing. 
Samples are near equilibrium with calcite implying both dissolution and precipitation of calcite are probable. Most samples have excess $\mathrm{Ca}$ and $\mathrm{HCO}_{3}{ }^{-}$due to dissolution of calcite and dolomite. Depletion of $\mathrm{HCO}_{3}{ }^{-}$in active intrusion areas point out at calcite precipitation. Samples with saltwater content less than $20 \%$ are undersaturated with dolomite while dolomite tends to precipitate at higher saltwater percentages. Limited cation exchange is also suspected to affect major ion concentrations in the mixing zone where $\mathrm{Na}^{+}, \mathrm{Mg}^{2+}$ and $\mathrm{K}^{+}$are depleted while $\mathrm{Ca}^{2+}$ is in excess of the theoretical mixing.

For the same percent of saltwater in a sample, the cation deviations are higher in active intrusion areas as opposed to previously intruded areas.

\section{References}

Appelo, C.A.J. and Postma, D. (2010). Geochemistry, Groundwater and Pollution. Amsterdam, The Netherlands: Taylor \& Francis.

Appelo, C. (1994). Cation and proton exchange, $\mathrm{pH}$ variations, and carbonate reactions in a freshening aquifer. Water Resour. Res., 30(10); 2793-2805.

Back, W., Hanshaw, B.B., Herman, J.S. and Van Driel, J.N. (1986). Differential dissolution of a Pleistocene reef in the ground-water mixing zone of coastal Yucatan, Mexico. Geology, 14(2); 137-140.

Barlow, P.M. and Reichard, E.G. (2010). Saltwater intrusion in coastal regions of North America. Hydrogeol. J., 18(1); 247-260.

Bear, J., Cheng, A.H.D., Sorek, S., Ouazar, D. and Herrera, I. (1999). Seawater Intrusion in Coastal Aquifers - Concepts, Methods and Practices. The Netherlands: Kluwer Academic Publishers.

Bradner, A., McPherson, B.F., Miller, R.L., Kish, G. and Bernard, B. (2005). Quality of Ground Water in the Biscayne Aquifer in Miami-Dade, Broward, and Palm Beach Counties, Florida, 1996-1998, with Emphasis on Contaminants. US Geol. Surv. Open-File Rep. 2004-1438.

Cooper, H.H., Kohout, F.A., Henry, H.R. and Glover, R.E. (1964). Sea water in coastal aquifers. US Geol. Surv. Water-Suppl. Pap 1613-C. 
Cunningham, K.J. (2004). Characterization of aquifer heterogeneity using cyclostratigraphy and geophysical methods in the upper part of the karstic Biscayne Aquifer, southeastern Florida. US Geol. Surv. Water Resour. Invest. Rep. 03-4208.

Cunningham, K.J., Wacker, M.A., Robinson, E., Dixon, J.F. and Wingard, G.L. (2006). A cyclostratigraphic and borehole-geophysical approach to development of a threedimensional conceptual hydrogeologic model of the karstic Biscayne Aquifer, southeastern Florida. US Geol. Surv. Scient. Invest. Rep. 2005-5235.

Dausman, A. and Langevin, C.D. (2005). Movement of the saltwater interface in the surficial aquifer system in response to hydrologic stresses and water-management practices, Broward County, Florida. US Geol. Surv. Scient. Invest. Rep. 2004-5256, 1.

Fish, J.E. and Stewart, M.T. (1991). Hydrogeology of the surficial aquifer system, Dade County, Florida. US Geol. Surv. Water Resour. Invest. Rep. 90-4108.

Ghiglieri, G., Carletti, A. and Pittalis, D. (2012). Analysis of salinization processes in the coastal carbonate aquifer of Porto Torres (NW Sardinia, Italy). J. Hydrol., 432; 4351.

Gimenez, E. and Morell, I. (1997). Hydrogeochemical analysis of salinization processes in the coastal aquifer of Oropesa (Castellon, Spain). Environ. Geol., 29 (1-2); 118131.

Harvey, R.W., Metge, D.W., Shapiro, A.M., Renken, R.A., Osborn, C.L., Ryan, J.N., Cunningham, K.J. and Landkamer, L. (2008). Pathogen and chemical transport in the karst limestone of the Biscayne Aquifer: 3. Use of microspheres to estimate the transport potential of Cryptosporidium parvum oocysts. Water Resour. Res., 44 (88); W08431.

Hem, J.D. (1985). Study and interpretation of the chemical characteristics of natural water. US Geol. Surv. Water-Suppl. Pap. 2254.

Klein, H. and Waller, B. (1984). Synopsis of saltwater intrusion in Dade County, Florida, through 1984. US Geol. Surv. Water-Res. Invest. Rep. 85-4101.

Kohout, F. (1960). Cyclic flow of salt water in the Biscayne Aquifer of southeastern Florida. J. Geophys. Res., 65(7); 2133-2141.

Kouzana, L., Mammou, A.B. and Felfoul, M.S. (2009). Seawater intrusion and associated processes: case of the Korba aquifer (Cap-Bon, Tunisia). C. R. Geosci., 341(1); 2135. 
Langevin, C.D. and Zygnerski, M. (2013). Effect of Sea Level Rise on Salt Water Intrusion near a Coastal Well Field in Southeastern Florida. Groundwater 51(5); 781-803.

Marella, R.L. (2009). Water withdrawals, use, and trends in Florida, 2005. US Geol. Surv. Scient. Invest. Rep. 2009-5125, 1.

Parkhurst, D.L. and Appelo, C. (2013). Description of input and examples for PHREEQC version 3: a computer program for speciation, batch-reaction, one-dimensional transport, and inverse geochemical calculations. US Geol. Surv. Techniques and Methods, book 6, chap. A-43.

Peters, C.J. (2008). Saltwater Intrusion Monitoring in the Biscayne Aquifer near Florida City, Miami-Dade County, Florida: 1996-2007. Proceedings of $20^{\text {th }}$ SWIM. , pp. 195-198.

Plummer, L., Vacher, H., Mackenzie, F., Bricker, O. and Land, L. (1976). Hydrogeochemistry of Bermuda: A case history of ground-water diagenesis of biocalcarenites. Geol. Soc. Am. Bull., 87(9); 1301-1316.

Price, R.M. and Herman, J.S. (1991). Geochemical investigation of salt-water intrusion into a coastal carbonate aquifer: Mallorca, Spain. Geol. Soc. Am. Bull., 103 (10); 1270-1279.

Price, R.M. (2001). Geochemical determinations of groundwater flow in Everglades National Park. PhD Dissertation, University of Miami, Coral Gables, FL.

Prinos, S.T., Wacker, M.A., Cunningham, K.J. and Fitterman, D.V. (2014). Origins and Delineation of Saltwater Intrusion in the Biscayne Aquifer and Changes in the Distribution of Saltwater in Miami-Dade County, Florida. US Geol. Surv. Scient. Invest. Rep. 2014-5025.

Pulido-Leboeuf, P. (2004). Seawater intrusion and associated processes in a small coastal complex aquifer (Castell de Ferro, Spain). Appl. Geochem., 19(10); 1517-1527.

Reese, R.S. and Cunningham, K.J. (2000). Hydrogeology of the gray limestone aquifer in southern Florida. US Geol. Surv. Water Resour. Invest. Rep. 99-4213.

Renken, R., Cunningham, K., Zygnerski, M., Wacker, M., Shapiro, A., Harvey, R., Metge, D., Osborn, C. and Ryan, J. (2005). Assessing the vulnerability of a municipal well field to contamination in a karst aquifer. Environ. Eng. Geosci., 11(4); 319-331.

Renken, R.A., Cunningham, K.J., Shapiro, A.M., Harvey, R.W., Zygnerski, M.R., Metge, D.W. and Wacker, M.A. (2008). Pathogen and chemical transport in the karst 
limestone of the Biscayne Aquifer: 1. Revised conceptualization of groundwater flow. Water Resour. Res., 44(8); W08431.

Rezaei, M., Sanz, E., Raeisi, E., Ayora, C., Vázquez-Suñé, E. and Carrera, J. (2005). Reactive transport modeling of calcite dissolution in the fresh-salt water mixing zone. J. Hydrol., 311(1); 282-298.

Romanov, D. and Dreybrodt, W. (2006). Evolution of porosity in the saltwaterfreshwater mixing zone of coastal carbonate aquifers: an alternative modelling approach. J. Hydrol., 329(3); 661-673.

Russak, A. and Sivan, O. (2010). Hydrogeochemical tool to identify salinization or freshening of coastal aquifers determined from combined field work, experiments, and modeling. Environ. Sci. Technol., 44(11); 4096-4102.

Sanford, W.E. and Konikow, L.F. (1989). Simulation of calcite dissolution and porosity changes in saltwater mixing zones in coastal aquifers. Water Resour. Res., 25(4); 655-667.

Sanz, E., Ayora, C. and Carrera, J. (2011). Calcite dissolution by mixing waters: geochemical modeling and flow-through experiments. Geolog. Acta, 9; 67-77.

Sivan, O., Yechieli, Y., Herut, B. and Lazar, B. (2005). Geochemical evolution and timescale of seawater intrusion into the coastal aquifer of Israel. Geochim. Cosmochim. Acta 69(3); 579-592.

Smart, P., Dawans, J. and Whitaker, F. (1988). Carbonate dissolution in a modern mixing zone. Nature 335(6193), 811-813.

Sonenshein, R.S. (1997). Delineation and extent of saltwater intrusion in the Biscayne Aquifer, eastern Dade County, Florida, 1995. US Geol. Surv. Water Resour. Invest. Rep. 96-4285.

Stoessell, R., Ward, W., Ford, B. and Schuffert, J. (1989). Water chemistry and CaCO3 dissolution in the saline part of an open-flow mixing zone, coastal Yucatan Peninsula, Mexico. Geol. Soc. Am. Bull., 101(2); 159-169.

Swayze, L.J. (1980). Water-Level Contour and Salt-Front Map, Hialeah-Miami Springs Well Field Area, Dade County, Florida, October 13, 1978. US Geol. Surv. Open-File Rep. 80-8.

Werner, A.D., Bakker, M., Post, V.E., Vandenbohede, A., Lu, C., Ataie-Ashtiani, B., Simmons, C.T. and Barry, D.A. (2013). Seawater intrusion processes, investigation and management: Recent advances and future challenges. Adv. Water Resour. 51; 326. 
Wicks, C.M., Herman, J.S., Randazzo, A.F. and Jee, J.L. (1995). Water-rock interactions in a modern coastal mixing zone. Geol. Soc. Am. Bull., 107(9); 1023-1032.

Wigley, T. and Plummer, L. (1976). Mixing of carbonate waters. Geochim. Cosmochim. Acta 40(9); 989-995. 


\section{GROUNDWATER MIXING AND URANIUM SPECIATION IN UNCONFINED AND CONFINED CARBONATE AQUIFERS}

\subsection{Abstract}

Uranium (U) is naturally present at elevated concentrations in many parts of the world. The main concern of natural uranium in drinking groundwater is its chemical toxicity rather than its radioactivity where toxicity is determined by its speciation and formation of complexes with other compounds. In this study, $U$ speciation due to groundwater mixing in the Biscayne Aquifer (unconfined) and the Upper Floridan Aquifer (confined), both carbonate formations in Florida, is modeled. Representative groundwater samples near saltwater interface of the Biscayne Aquifer and from an aquifer storage and recovery (ASR) site in the Upper Floridan aquifer were used in modeling. Speciation was calculated using the geochemical code PHREEQC with updated thermodynamic database for U complexes. Results indicate that calcium-uranyl carbonates $\left(\mathrm{Ca}_{2} \mathrm{UO}_{2}\left(\mathrm{CO}_{3}\right)_{3}\right.$ and $\left.\mathrm{CaUO}_{2}\left(\mathrm{CO}_{3}\right)_{3}{ }^{2-}\right)$ dominate over the near-neutral $\mathrm{pH}$ range of the Biscayne Aquifer samples (pH 6.6 to 7.2), making up more than $98 \%$ of the species. Mixing simulations of ASR resulted in $\mathrm{pH}$ of 6.70 to 7.97 and calcium-uranyl carbonates dominated the speciation. Equilibration with calcite resulted in higher percentage of $\mathrm{Ca}_{2} \mathrm{UO}_{2}\left(\mathrm{CO}_{3}\right)_{3}$ when compared to mixing only. Changes in redox potential (pE of -3 to 3 ) and $U$ concentration (up to $30 \mu \mathrm{g} / \mathrm{L}$ ) in groundwater appeared to have negligible effects on speciation as Ca-uranyl carbonates remained dominant. Thus, fate of $U$ may be predominantly described by that of the highly mobile Ca-uranyl carbonates over the neutral to alkaline $\mathrm{pH}$ of carbonate aquifers for the expected ranges of concentration. 


\subsection{Introduction}

Uranium (U) is found in groundwater due to its natural occurrence in granites, shales and carbonates. Source minerals include uraninite $\left(\mathrm{UO}_{2}\right)$, pitchblende $\left(\mathrm{U}_{3} \mathrm{O}_{8}\right)$, carnotite $\left(\mathrm{K}_{2}\left(\mathrm{UO}_{2}\right)_{2}\left(\mathrm{VO}_{4}\right)_{2} .3 \mathrm{H}_{2} \mathrm{O}\right)$ and also phosphate minerals. Large concentrations of dissolved uranium have been detected in groundwater supplies in Europe (Norrström and Löv, 2014; Prat et al., 2009; Stalder et al., 2012) and the US (Brown et al., 2007; Jurgens et al., 2010). Uranium can also be enriched in groundwater due to anthropogenic activities, such as mill tailings of $\mathrm{U}$ and application of phosphate fertilizers. In Florida, $\mathrm{U}$ occurs in excess of 25 ppm in limestone in the Floridian Aquifer System and about 30\% could be leached under oxidizing conditions in laboratory settings (Arthur et al., 2007; Arthur and Cowart, 2001). Uranium concentrations in samples from public supply wells in the Upper Floridan aquifer are generally below the current drinking water standard of 30 $\mu \mathrm{g} / \mathrm{L}$ and range from $3.0 \mu \mathrm{g} / \mathrm{L}$ to $5.4 \mu \mathrm{g} / \mathrm{L}$ (Brown et al., 2007); however sporadic exceedances of the standard have been observed in public-supply wells due to humaninduced changes to the flow system. In the saltwater intrusion area of the Biscayne Aquifer, U averaged $0.18 \mu \mathrm{g} / \mathrm{L}$ (Prinos et al., 2014). Despite its radioactivity, U in groundwater is environmentally significant due to its chemical toxicity (Norrström and Löv, 2014;Prat et al., 2009). U mobility and bioavailability is dependent on its speciation and that determines chemical toxicity. $U$ may occur in groundwater in three oxidation states as $\mathrm{U}(\mathrm{IV}), \mathrm{UO}_{2}{ }^{+}$and $\mathrm{UO}_{2}{ }^{2+}$. In anoxic aquifers (low redox potential), $\mathrm{U}$ occurs as $\mathrm{U}(\mathrm{IV})$ and $\mathrm{UO}_{2}{ }^{+}$. Whereas $\mathrm{U}(\mathrm{IV})$ is relatively immobile and precipitates as a solid phase (e.g., uraninite), $\mathrm{UO}_{2}{ }^{+}$forms soluble but relatively unstable complexes. The oxidized form, $\mathrm{U}(\mathrm{VI})$, most commonly exists as $\mathrm{UO}_{2}{ }^{2+}$ (uranyl) and is highly mobile. The uranyl 
cation forms complexes with carbonate, hydroxide, sulfate and phosphate anions. Uranylhydroxide complexes are present at neutral pH in pure water (Schulze and Merkel, 2012). Where carbonate is present, uranyl-carbonate complexes dominate the speciation when pH is greater than 5 (Nair and Merkel, 2011; Prat et al., 2009). Carbonate complexes inhibit attraction of uranyl to minerals and increase its mobility (Curtis et al., 2006; Davis et al., 2004). Complexes of uranyl-carbonates with alkaline earth metals, such as Ca have been found to dominate speciation in neutral to alkaline $\mathrm{pH}$ ranges. Results of batch experiments and simulation by Davis et al. (2004) and Curtis et al. (2006) indicated $\mathrm{CaUO}_{2}\left(\mathrm{CO}_{3}\right)_{3}{ }^{2-}$ and $\mathrm{Ca}_{2} \mathrm{UO}_{2}\left(\mathrm{CO}_{3}\right)_{3}$ dominated the $\mathrm{U}$ speciation accounting up to $98.8 \%$ of dissolved $\mathrm{U}(\mathrm{VI})$. This is supported by speciation models that included calcium-uranyl carbonates (Nair and Merkel, 2011; Norrström and Löv, 2014; Prat et al., 2009).

Besides mobility, $\mathrm{U}$ speciation in drinking water affects the toxicity of drinking water supplies and influences treatment methods. Some human studies reported no adverse effects even when U exceeded drinking water guidelines (Kurttio et al., 2006; Seldén et al., 2009; Zamora et al., 2009). In Finland, for example, the predominance of $\mathrm{CaUO}_{2}\left(\mathrm{CO}_{3}\right)_{3}{ }^{2-}$ and $\mathrm{Ca}_{2} \mathrm{UO}_{2}\left(\mathrm{CO}_{3}\right)_{3}$ species resulted in non-toxicity of drinking water supplies despite the unusually high $\mathrm{U}$ concentrations reaching $3.4 \mathrm{mg} / \mathrm{l}$ (Prat et al., 2009). Therefore, in addition to total concentration, $\mathrm{U}$ speciation is very important in risk assessment because changes in environmental conditions strongly influence the behavior of trace elements by changing the forms in which they occur. Speciation also affects water treatment by membrane systems as some species of $U$ cause membrane fouling during its removal from brackish groundwater (Rossiter et al., 2010). Thus, in the event that total $\mathrm{U}$ concentration exceeds MCL limits, $\mathrm{U}$ speciation may determine toxicity of 
the water and its ease of treatment. $U$ may not be a significant water quality issue during ASR in Florida but higher than background levels of $U$ are recovered (Arthur et al., 2007). Therefore modeling of $U$ speciation and mobility is of geochemical interest.

Groundwater developments, such as increased pumping and irrigation change the rate and quality of recharge which could lead to elevated U in drinking water (Jurgens et al., 2010). In this context, mixing of groundwater and fresh water due to saltwater intrusion may change water quality (such as $\mathrm{pH}$ and redox potential) impacting $\mathrm{U}$ speciation. Besides, ASR operations may affect $U$ speciation due to mixing between recharge water and native groundwater. In this paper, $\mathrm{U}$ speciation is modeled for samples collected at the saltwater mixing zone of the unconfined Biscayne Aquifer in South Florida (Prinos et al., 2014). Twenty-nine groundwater samples were used to identify which $U$ species dominate in the $\mathrm{pH}$ range of the samples (Table 4.2). These samples can be used to represent mixing between freshwater and saltwater in a carbonate aquifer. Speciation due to mixing at an ASR site is also modeled. Data at the Kissimmee River ASR (KRASR) facility is used as example of recharge into the confined, carbonate Upper Floridan aquifer in central Florida (Mirecki et al., 2012). The overall objective is to identify dominant $\mathrm{U}$ species in the carbonate aquifers and the effect of groundwater mixing on speciation. Previous U speciation modeling was mainly based on batch experiments and used artificial electrolytes. A few cases have studied $\mathrm{U}$ speciation in drinking water (Norrström and Löv, 2014; Prat et al., 2009) from granite bedrocks and with relatively high U concentrations. Modeling herein uses groundwater samples from a carbonate aquifer and considers the effects of mixing and calcite equilibrium at low $\mathrm{U}$ concentrations. Samples from mixing zones of the Biscayne Aquifer and from cycle tests 
of the KRASR had U concentrations much lower than the U.S. EPA MCL (about 1 ug/L). The samples are not toxic at such very low concentrations but $\mathrm{U}$ may be mobilized due to its leaching from the aquifer when redox conditions are altered (e.g., by recharge water during ASR). The aim is to model $\mathrm{U}$ speciation based on measured element concentrations thus the speciation represents the average field conditions which have low $\mathrm{U}$ concentration. Sensitivity of speciation is then tested by hypothetically increasing $\mathrm{U}$ to its MCL concentration. Thus speciation of the samples is predicted at larger $U$ concentrations. All measured ions are included in speciation calculations to incorporate the effect of competition between various ions in solution. Dominance of non-toxic forms of $U$ at the hypothetical large concentrations may imply non-toxicity of the water incase U is slightly larger than its MCL.

\subsection{Speciation modeling}

Speciation is modeled using the geochemical code PHREEQC version 3 (Parkhurst and Appelo, 2013) with updated U thermodynamic database from the Nuclear Energy Agency (Guillaumont and Mompean, 2003). Formation constants of alkaline earthuranyl carbonates are obtained from literature. The speciation reactions and corresponding formation constants used in the modeling are summarized in Table 4.1. Dong and Brooks (2006) and Bernhard et al. (2001) report different formation constants for $\mathrm{CaUO}_{2}\left(\mathrm{CO}_{3}\right)_{3}{ }^{2-}$ while they report similar values for $\mathrm{Ca}_{2} \mathrm{UO}_{2}\left(\mathrm{CO}_{3}\right)_{3}$. This means speciation varies depending on which formation constant is used. Dong and Brooks (2006) used anion exchange chromatography to determine the formation constants of the ternary complexes. Prat et al. (2009) suggest that the Dong and Brooks (2006) values are more accurate for $\mathrm{CaUO}_{2}\left(\mathrm{CO}_{3}\right)_{3}{ }^{2-}$ because Bernhard et al.'s work is only a rough 
evaluation based on variation of their florescence measurements. The formation constants of Dong and Brooks (2006) have been used in this work. $\mathrm{MgUO}_{2}\left(\mathrm{CO}_{3}\right)_{3}{ }^{2-}$ is generally dominated by calcium-uranyl carbonates and it may only be significant at very large magnesium concentrations such as in mining areas (Norrström and Löv, 2014). 
Table 4.1 Aqueous Uranium species and their formation constants used in modeling.

\begin{tabular}{|c|c|}
\hline Aqueous species reaction & Log $\mathrm{K}$ at $25^{\circ} \mathrm{C}(\mathrm{I}=0)^{\mathrm{a}}$ \\
\hline $\mathrm{UO}_{2}^{2+}+\mathrm{H}_{2} \mathrm{O}=\mathrm{UO}_{2} \mathrm{OH}^{+}+\mathrm{H}^{+}$ & -5.25 \\
\hline $\mathrm{UO}_{2}{ }^{2+}+2 \mathrm{H}_{2} \mathrm{O}=\mathrm{UO}_{2}(\mathrm{OH})_{2}(\mathrm{aq})+2 \mathrm{H}^{+}$ & -12.15 \\
\hline $\mathrm{UO}_{2}{ }^{2+}+3 \mathrm{H}_{2} \mathrm{O}=\mathrm{UO}_{2}(\mathrm{OH})_{3}^{-}(\mathrm{aq})+3 \mathrm{H}^{+}$ & -20.25 \\
\hline $2 \mathrm{UO}_{2}^{2+}+2 \mathrm{H}_{2} \mathrm{O}=\left(\mathrm{UO}_{2}\right)_{2}(\mathrm{OH})_{2}{ }^{2+}+2 \mathrm{H}^{+}$ & -5.62 \\
\hline $3 \mathrm{UO}_{2}{ }^{2+}+4 \mathrm{H}_{2} \mathrm{O}=\left(\mathrm{UO}_{2}\right)_{3}(\mathrm{OH})_{4}{ }^{2+}+4 \mathrm{H}^{+}$ & -11.90 \\
\hline $3 \mathrm{UO}_{2}{ }^{2+}+5 \mathrm{H}_{2} \mathrm{O}=\left(\mathrm{UO}_{2}\right)_{3}(\mathrm{OH})_{5}{ }^{+}+5 \mathrm{H}^{+}$ & -15.55 \\
\hline $3 \mathrm{UO}_{2}^{2+}+7 \mathrm{H}_{2} \mathrm{O}=\left(\mathrm{UO}_{2}\right)_{3}(\mathrm{OH})_{7}^{-}+7 \mathrm{H}^{+}$ & -32.20 \\
\hline $4 \mathrm{UO}_{2}{ }^{2+}+7 \mathrm{H}_{2} \mathrm{O}=\left(\mathrm{UO}_{2}\right)_{4}(\mathrm{OH})_{7}^{+}+7 \mathrm{H}^{+}$ & -21.90 \\
\hline $\mathrm{UO}_{2}{ }^{2+}+\mathrm{CO}_{3}{ }^{2-}=\mathrm{UO}_{2} \mathrm{CO}_{3}(\mathrm{aq})$ & 9.94 \\
\hline $\mathrm{UO}_{2}^{2+}+2 \mathrm{CO}_{3}^{2-}=\mathrm{UO}_{2}\left(\mathrm{CO}_{3}\right)_{2}^{2-}$ & 16.61 \\
\hline $\mathrm{UO}_{2}^{2+}+3 \mathrm{CO}_{3}^{2-}=\mathrm{UO}_{2}\left(\mathrm{CO}_{3}\right)_{3}^{4-}$ & 21.84 \\
\hline $\mathrm{UO}_{2}{ }^{2+}+4 \mathrm{H}_{2} \mathrm{O}=\mathrm{UO}_{2}(\mathrm{OH})_{4}{ }^{2-}+4 \mathrm{H}^{+}$ & -32.40 \\
\hline $2 \mathrm{UO}_{2}{ }^{2+}+\mathrm{H}_{2} \mathrm{O}=\left(\mathrm{UO}_{2}\right)_{2}(\mathrm{OH})^{3+}+\mathrm{H}^{+}$ & -2.70 \\
\hline $3 \mathrm{UO}_{2}^{2+}+6 \mathrm{CO}_{3}{ }^{2-}=\left(\mathrm{UO}_{2}\right) 3\left(\mathrm{CO}_{3}\right)_{6}{ }^{6-}$ & 54.00 \\
\hline $2 \mathrm{UO}_{2}{ }^{2+}+\mathrm{CO}_{3}{ }^{2-}+3 \mathrm{H}_{2} \mathrm{O}=\left(\mathrm{UO}_{2}\right)_{2} \mathrm{CO}_{3}(\mathrm{OH})_{3}{ }^{-}+3 \mathrm{H}^{+}$ & -0.85 \\
\hline $3 \mathrm{UO}_{2}{ }^{2+}+\mathrm{CO}_{3}{ }^{2-}+3 \mathrm{H}_{2} \mathrm{O}=\left(\mathrm{UO}_{2}\right)_{3} \mathrm{CO}_{3}(\mathrm{OH})_{3}{ }^{+}+3 \mathrm{H}^{+}$ & 0.66 \\
\hline $\mathrm{UO}_{2}^{2+}+\mathrm{Cl}^{-}=\mathrm{UO}_{2} \mathrm{Cl}^{+}$ & 0.17 \\
\hline $\mathrm{Ca}^{2+}+\mathrm{UO}_{2}{ }^{2+}+3 \mathrm{CO}_{3}{ }^{2-}=\mathrm{CaUO}_{2}\left(\mathrm{CO}_{3}\right)_{3}{ }^{2-}$ & $25.40^{\mathrm{b}}, 26.93^{\mathrm{b}}, 27.18^{\mathrm{c}}$ \\
\hline $2 \mathrm{Ca}^{2+}+\mathrm{UO}_{2}{ }^{2+}+3 \mathrm{CO}_{3}^{2-}=\mathrm{Ca}_{2} \mathrm{UO}_{2}\left(\mathrm{CO}_{3}\right)_{3}{ }^{0}(\mathrm{aq})$ & $30.55^{\mathrm{a}, \mathrm{b}}, 30.79^{\mathrm{b}}, 30.7^{\mathrm{c}}$ \\
\hline $\mathrm{UO}_{2}{ }^{2+}+2 \mathrm{Cl}^{-}=\mathrm{UO}_{2} \mathrm{Cl}_{2}(\mathrm{aq})$ & -1.10 \\
\hline $\mathrm{Mg}^{2+}+\mathrm{UO}_{2}{ }^{2+}+3 \mathrm{CO}_{3}{ }^{2-}=\mathrm{MgUO}_{2}\left(\mathrm{CO}_{3}\right)_{3}{ }^{2-}$ & $26.24^{\mathrm{b}}, 26.11^{\mathrm{c}}$ \\
\hline $\mathrm{UO}_{2}^{2+}+\mathrm{SO}_{4}^{2-}=\mathrm{UO}_{2}\left(\mathrm{SO}_{4}\right)(\mathrm{aq})$ & 3.15 \\
\hline $\mathrm{UO}_{2}{ }^{2+}+2 \mathrm{SO}_{4}{ }^{2-}=\mathrm{UO}_{2}\left(\mathrm{SO}_{4}\right)_{2}^{2-}(\mathrm{aq})$ & 4.14 \\
\hline
\end{tabular}

${ }^{a}$ Log K values at ionic strength, I=0 from Guillaumont and Mompean (2003), unless otherwise indicated

b Bernhard et al. (2001)

${ }^{\mathrm{c}}$ Dong and Brooks (2006) 
Groundwater samples along with the freshwater and saltwater end members of the Biscayne Aquifer are shown in Table 4.2. Freshwater composition is average of well samples that tap the Biscayne Aquifer inland of the mixing zone (Bradner et al., 2005). Salt water end member has composition of typical seawater (Hem, 1985). A description of the mixing model methods is given in chapter 3. Groundwater samples representing saltwater mixing were compiled from Prinos et al. (2014) who reported a total of 52 groundwater samples in the mixing zone of the Biscayne Aquifer; 29 of these samples had $\mathrm{U}$ concentration data and they were used to identify $\mathrm{U}$ complexes in the mixing zone (Table 4.2). The sample $\mathrm{pH}$ ranges from 6.61 to 7.21 . Temperature of the samples varies between 23.9 and $27.2{ }^{\circ} \mathrm{C}$ with a median of 25.7. Average ion concentrations generally increase with increasing chloride content (salinity). Total $U$ is very low at a median value of $0.06 \mu \mathrm{g} / \mathrm{L}$ and a maximum concentration of $8.83 \mu \mathrm{g} / \mathrm{L}$. A weak correlation $\left(\mathrm{R}^{2}=0.54\right)$, shown in Figure 4.1, is observed between measured U concentrations and chloride (Cl) content when samples with $[\mathrm{U}]>1 \mu \mathrm{g} / \mathrm{L}$ were considered. Therefore, additional $\mathrm{U}$ leaching mechanisms should be mobilizing $U$ besides simple mixing and calcite dissolution-precipitation reactions. 


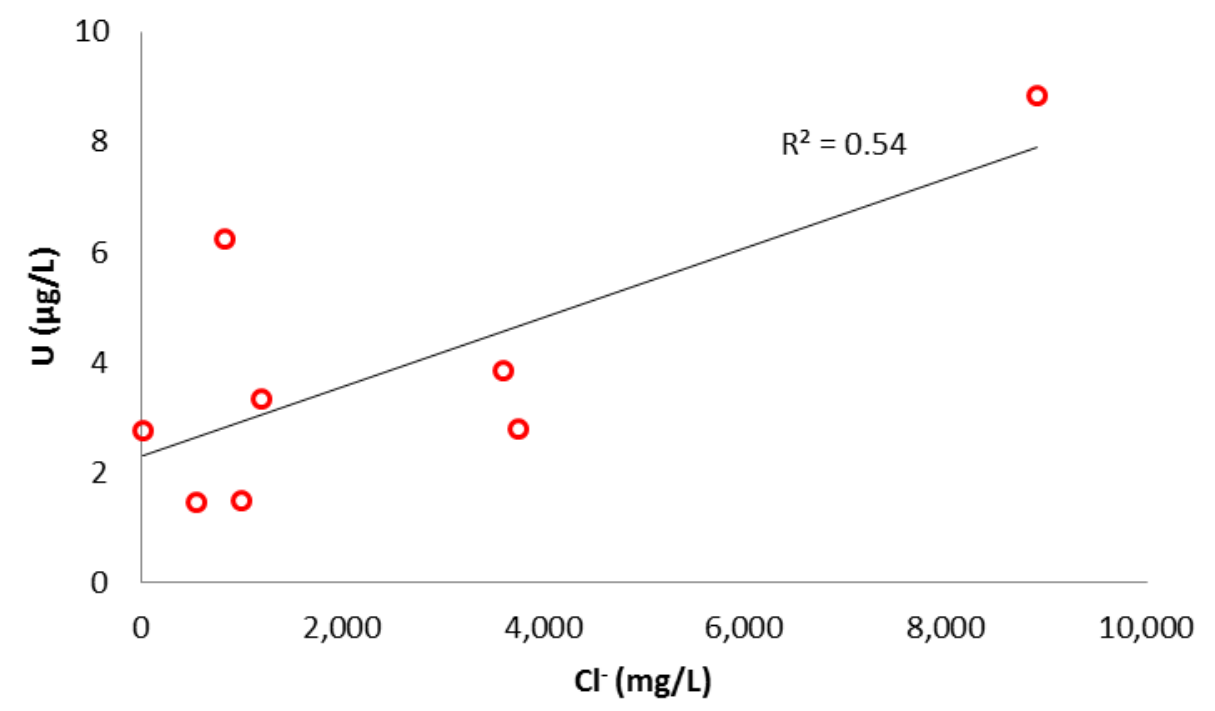

Figure 4.1 Correlation between $\mathrm{U}$ and $\mathrm{Cl}$ in Biscayne Aquifer samples, $[\mathrm{U}]>1 \mu \mathrm{g} / \mathrm{L}$.

Groundwater quality for Kissimmee River ASR (KRASR) is shown in Table 4.3 (Mirecki et al., 2012). The native groundwater at KRASR is relatively fresh with low chloride. The aquifer is characterized by sulfate- reducing conditions and has slightly alkaline $\mathrm{pH}$, moderate carbonate alkalinity and relatively low concentrations of major cations. $\mathrm{U}$ concentration in the zone of recharge is assumed to be $3 \mu \mathrm{g} / \mathrm{l}$ based on average concentration for Florida while the oxidized recharge water is assumed free of uranium. The mixing model uses the native and recharge water end members shown in Table 4.3. Calcite is allowed to equilibrate with the mixture in subsequent modeling. 
Table 4.2 Groundwater quality of samples from the mixing zone of the Biscayne Aquifer

(Prinos et al., 2014).

\begin{tabular}{|c|c|c|c|c|c|c|c|c|c|c|c|c|}
\hline Sample & $\begin{array}{l}\text { Temp. } \\
{ }^{\circ} \mathrm{C}\end{array}$ & $\mathrm{pH}$ & $\begin{array}{l}\text { Alk. } \\
\text { mg/L }\end{array}$ & $\begin{array}{l}\mathrm{Ca}^{2+} \\
\mathrm{mg} / \mathrm{L}\end{array}$ & $\begin{array}{l}\mathrm{Mg}^{2+} \\
\mathrm{mg} / \mathrm{L}\end{array}$ & $\begin{array}{l}\mathrm{Na}^{+} \\
\mathrm{mg} / \mathrm{L}\end{array}$ & $\begin{array}{l}\mathrm{K}^{+} \\
\mathrm{mg} / \mathrm{L}\end{array}$ & $\begin{array}{l}\mathrm{Cl}^{-} \\
\mathrm{mg} / \mathrm{L}\end{array}$ & $\begin{array}{l}\mathrm{SO}_{4}{ }^{2-} \\
\mathrm{mg} / \mathrm{L}\end{array}$ & $\begin{array}{l}\mathrm{F}^{-} \\
\mathrm{mg} / \mathrm{L}\end{array}$ & $\begin{array}{l}\mathrm{Fe} \\
\mathrm{mg} / \mathrm{L}\end{array}$ & $\begin{array}{l}\mathrm{U} \\
\mathrm{ug} / \mathrm{L}\end{array}$ \\
\hline F-279 & 25.8 & 6.79 & 291 & 339 & 158 & 1640 & 24 & 3480 & 367 & 0.18 & 6.09 & 0.02 \\
\hline F-45 & 27.2 & 7.14 & 227 & 95 & 4 & 53 & 3 & 103 & 35 & 0.17 & 1.11 & 0.01 \\
\hline G-3603 & 25.9 & 7.01 & 289 & 102 & 5 & 35 & 2 & 74 & 7 & 0.20 & 0.77 & 0.06 \\
\hline G-3606 & 26.0 & 6.99 & 290 & 104 & 3 & 26 & 1 & 36 & 19 & 0.16 & 1.45 & 0.03 \\
\hline G-3607 & 25.4 & 7.11 & 274 & 84 & 4 & 36 & 2 & 58 & 14 & 0.09 & 0.33 & 0.14 \\
\hline G-3608 & 24.5 & 7.09 & 264 & 87 & 7 & 100 & 2 & 173 & 15 & 0.12 & 0.62 & 0.01 \\
\hline G-3608 & 24.6 & 6.96 & 267 & 82 & 7 & 87 & 2 & 158 & 17 & 0.13 & 0.58 & 0.02 \\
\hline G-3610 & 25.7 & 7.21 & 242 & 88 & 3 & 27 & 1 & 47 & 26 & 0.15 & 0.82 & 0.02 \\
\hline G-3700 & 25.5 & 7.19 & 229 & 79 & 3 & 20 & 5 & 23 & 30 & 0.20 & 0.01 & 2.77 \\
\hline G-3855 & 23.9 & 6.72 & 232 & 495 & 122 & 1650 & 22 & 3760 & 175 & 0.08 & 0.11 & 2.78 \\
\hline G-3856 & 24.2 & 7.14 & 207 & 120 & 21 & 258 & 9 & 553 & 48 & 0.13 & 0.00 & 1.46 \\
\hline G-894 & 26.2 & 7.19 & 221 & 85 & 2 & 13 & 1 & 18 & 30 & 0.20 & 0.88 & 0.01 \\
\hline G-896 & 25.3 & 7.15 & 257 & 87 & 15 & 115 & 4 & 211 & 25 & 0.11 & 0.70 & 0.02 \\
\hline G-3600 & 25.5 & 6.95 & 314 & 487 & 1120 & 7820 & 312 & 15400 & 1910 & 0.21 & 7.27 & 0.08 \\
\hline G-3601 & 25.7 & 6.96 & 329 & 176 & 59 & 624 & 16 & 1270 & 114 & 0.18 & 3.28 & 0.02 \\
\hline G-3602 & 25.3 & 6.90 & 312 & 264 & 199 & 1990 & 50 & 4050 & 423 & 0.17 & 5.33 & 0.05 \\
\hline G-3604 & 26.2 & 7.09 & 267 & 224 & 312 & 2600 & 88 & 5330 & 643 & 0.38 & 4.51 & 0.11 \\
\hline G-3605 & 26.7 & 6.93 & 275 & 182 & 91 & 955 & 26 & 1940 & 232 & 0.17 & 2.03 & 0.08 \\
\hline G-3609 & 26.2 & 6.90 & 261 & 180 & 55 & 557 & 8 & 1180 & 84 & 0.13 & 1.10 & 0.03 \\
\hline G-3609 & 26.2 & 6.90 & 275 & 178 & 55 & 546 & 7 & 1220 & 73 & 0.13 & 1.04 & 0.06 \\
\hline G-3702 & 25.4 & 7.03 & 233 & 171 & 37 & 470 & 11 & 997 & 109 & 0.15 & 0.22 & 1.50 \\
\hline G-939 & 27.0 & 7.01 & 260 & 217 & 206 & 1650 & 50 & 3410 & 363 & 0.15 & 1.00 & 0.58 \\
\hline
\end{tabular}


Table 4.2 (continued)

\begin{tabular}{|c|c|c|c|c|c|c|c|c|c|c|c|c|}
\hline Sample & $\begin{array}{l}\text { Temp. } \\
{ }^{\circ} \mathrm{C}\end{array}$ & $\mathrm{pH}$ & $\begin{array}{l}\text { Alk. } \\
\text { mg/L }\end{array}$ & $\begin{array}{l}\mathrm{Ca}^{2+} \\
\mathrm{mg} / \mathrm{L}\end{array}$ & $\begin{array}{l}\mathrm{Mg}^{2+} \\
\mathrm{mg} / \mathrm{L}\end{array}$ & $\begin{array}{l}\mathrm{Na}^{+} \\
\mathrm{mg} / \mathrm{L}\end{array}$ & $\begin{array}{l}\mathrm{K}^{+} \\
\mathrm{mg} / \mathrm{L}\end{array}$ & $\begin{array}{l}\mathrm{Cl}^{-} \\
\mathrm{mg} / \mathrm{L}\end{array}$ & $\begin{array}{l}\mathrm{SO}_{4}{ }^{2-} \\
\mathrm{mg} / \mathrm{L}\end{array}$ & $\begin{array}{l}\mathrm{F}^{-} \\
\mathrm{mg} / \mathrm{L}\end{array}$ & $\begin{array}{l}\mathrm{Fe} \\
\mathrm{mg} / \mathrm{L}\end{array}$ & $\begin{array}{l}\mathrm{U} \\
\mathrm{ug} / \mathrm{L}\end{array}$ \\
\hline G-3611 & 25.7 & 7.09 & 238 & 102 & 4 & 85 & 2 & 175 & 26 & 0.15 & 0.17 & 0.01 \\
\hline G-3615 & 25.3 & 6.61 & 225 & 459 & 130 & 1440 & 17 & 3600 & 201 & 0.07 & 0.01 & 3.85 \\
\hline G-3698 & 25.8 & 6.92 & 206 & 252 & 27 & 493 & 9 & 1200 & 44 & 0.13 & 0.02 & 3.34 \\
\hline G-3699 & 25.1 & 6.72 & 281 & 561 & 460 & 4190 & 79 & 8910 & 803 & 0.09 & 0.11 & 8.83 \\
\hline G-3701 & 25.4 & 7.06 & 204 & 181 & 21 & 353 & 3 & 832 & 50 & 0.26 & 0.06 & 6.25 \\
\hline G-3704 & 26.6 & 6.74 & 254 & 441 & 273 & 2850 & 53 & 6190 & 510 & 0.16 & 8.08 & 0.23 \\
\hline G-3705 & 26.2 & 6.77 & 277 & 288 & 29 & 530 & 1 & 1290 & 114 & 0.14 & 4.57 & 0.02 \\
\hline $\mathrm{FW}^{*}$ & 28.5 & 7.40 & 235 & 75 & 5 & 25 & 4 & 39 & 12 & 0.20 & 0.07 & 0.60 \\
\hline $\mathrm{SW}^{* *}$ & 25.0 & 8.00 & 142 & 410 & 1350 & 10500 & 390 & 19000 & 2700 & 1.30 & 0.00 & 3.00 \\
\hline
\end{tabular}


Table 4.3 Average Upper Floridan Aquifer (UFA) and recharge water qualities at KRASR (Mirecki et al., 2012).

\begin{tabular}{lll}
\hline Constituent or parameter & $\begin{array}{l}\text { Recharge water } \\
\text { quality }\end{array}$ & UFA water quality \\
\hline Temperature $\left({ }^{\circ} \mathrm{C}\right)$ & 25.3 & 25.2 \\
$\mathrm{pH}$ & 6.7 & 7.97 \\
Oxidation-reduction potential & 130 & -179 \\
$(\mathrm{mV})$ & & \\
Dissolved oxygen $(\mathrm{mg} / \mathrm{L})$ & 4.5 & 0.02 \\
Calcium $(\mathrm{mg} / \mathrm{L})$ & 19.2 & 47 \\
Magnesium $(\mathrm{mg} / \mathrm{L})$ & 4.8 & 33 \\
Sodium $(\mathrm{mg} / \mathrm{L})$ & 16.1 & 150 \\
Potasium $(\mathrm{mg} / \mathrm{L})$ & 4 & 7.2 \\
Sulfate $(\mathrm{mg} / \mathrm{L})$ & 15.6 & 150 \\
Sulfide $(\mathrm{mg} / \mathrm{L})$ & 0.1 & $<1$ \\
Chloride $(\mathrm{mg} / \mathrm{L})$ & 31.1 & 260 \\
Total alkalinity as CaCO3 $(\mathrm{mg} / \mathrm{L})$ & 50 & 84 \\
Dissolved organic carbon $(\mathrm{mg} / \mathrm{L})$ & 15.3 & 1.2 \\
Total organic carbon $(\mathrm{mg} / \mathrm{L})$ & 16.3 & 1.3 \\
Arsenic $(\mu \mathrm{g} / \mathrm{L})$ & 0.9 & 1.6 \\
Iron $(\mu \mathrm{L} / \mathrm{L})$ & 226 & 65 \\
Manganese $(\mu \mathrm{g} / \mathrm{L})$ & 4.5 & 4.3 \\
Nitrate $(\mathrm{mg} / \mathrm{L})$ & 0.142 & $<0.025$ \\
Phosphorus $(\mu \mathrm{g} / \mathrm{L})$ & 64 & $<0.008$ \\
\hline
\end{tabular}

\subsection{Results and discussion}

4.3.1 Mixing and speciation driven by saltwater intrusion (unconfined Biscayne Aquifer)

Figure 4.2 shows the percent fraction of species in the Biscayne Aquifer samples. The speciation is dominated by Ca-uranyl carbonates over the $\mathrm{pH}$ range of the samples (6.6 -7.2). These complexes make up more than $98 \%$ of the species. The neutrally charged $\mathrm{Ca}_{2} \mathrm{UO}_{2}\left(\mathrm{CO}_{3}\right)_{3}$ complex makes more than $61 \%$ of the total $\mathrm{U}$ while the negatively charged $\mathrm{CaUO}_{2}\left(\mathrm{CO}_{3}\right)_{3}{ }^{2-}$ makes up between 17 and $36 \%$ of total $\mathrm{U}$. The percent of $\mathrm{Ca}_{2} \mathrm{UO}_{2}\left(\mathrm{CO}_{3}\right)_{3}$ is observed to decrease with increasing $\mathrm{pH}$ while $\mathrm{CaUO}_{2}\left(\mathrm{CO}_{3}\right)_{3}{ }^{2-}$ increases. The dominance of Ca-uranyl-carbonates in the alkaline $\mathrm{pH}$ range is also observed from the theoretical speciation curves computed using average 
water quality of the freshwater sample (Figure 4.3). In the acidic range of $\mathrm{pH} 4.5$ to 6, $\mathrm{UO}_{2} \mathrm{CO}_{3}$ dominates the theoretical speciation but none of the samples had $\mathrm{pH}$ lower than 6.6. The Eh-pH diagram (Figure 4.3) shows the clear dominance of $\mathrm{Ca}_{2} \mathrm{UO}_{2}\left(\mathrm{CO}_{3}\right)_{3}$ when the redox potential (Eh) is greater than zero and $\mathrm{pH}$ is between 6 and 10. Redox potential of the samples is calculated from the redox pair $O(-2) / O(0)$ and varies between 0.77 and $0.80 \mathrm{~V}$. For these oxidized samples whose $\mathrm{pH}$ varies between 6.6 and 7.2, therefore, $\mathrm{Ca}_{2} \mathrm{UO}_{2}\left(\mathrm{CO}_{3}\right)_{3}$ is expected to dominate (Figure 4.3). At $\mathrm{pH}<4.5, \mathrm{UO}_{2}{ }^{2+}$ and $\mathrm{UO}_{2} \mathrm{~F}^{+}$are the two dominant species.

Similar results of Ca-uranyl carbonate dominance were obtained by Norrström and Löv (2014) in groundwater samples from Sweden where the calcium-uranyl carbonates comprised up to $80 \%$ of the species for $\mathrm{pH} 7.2$ to 7.4. Compared to Norrström and Löv (2014), Ca concentration and alkalinity are higher in the Biscayne Aquifer with median values of $178 \mathrm{mg} / \mathrm{L}$ and $261 \mathrm{mg} / \mathrm{L}$, respectively. This could explain the higher percentage of Ca-uranyl carbonates at comparatively lower $\mathrm{pH}$ in the Biscayne Aquifer. However, given very low $U$ concentration of the samples, no correlation is observed between Ca concentration and the concentration of Ca-uranyl-carbonates in the Biscayne Aquifer (Figure 4.2). Effect of pH, on the other hand, can be seen where there is a general trend of increasing fraction of $\mathrm{CaUO}_{2}\left(\mathrm{CO}_{3}\right)_{3}{ }^{2-}$ with increasing $\mathrm{pH}$ while $\mathrm{Ca}_{2} \mathrm{UO}_{2}\left(\mathrm{CO}_{3}\right)_{3}$ decreases (Figure 4.2). This is also seen in the theoretical speciation curve (Figure 4.3) where the dominance of the neutral complex decreases and that of the negative complex increases up to $\mathrm{pH}$ of around 10. The samples reflect mixing of fresh groundwater and saltwater in different proportions; hence, during saltwater intrusion into the carbonate Biscayne Aquifer, the Ca-uranyl carbonates will dominate speciation because $\mathrm{pH}$ is 
buffered around 7. In the event that $\mathrm{pH}$ drops below $6, \mathrm{UO}_{2} \mathrm{CO}_{3}$ is expected to be dominant.
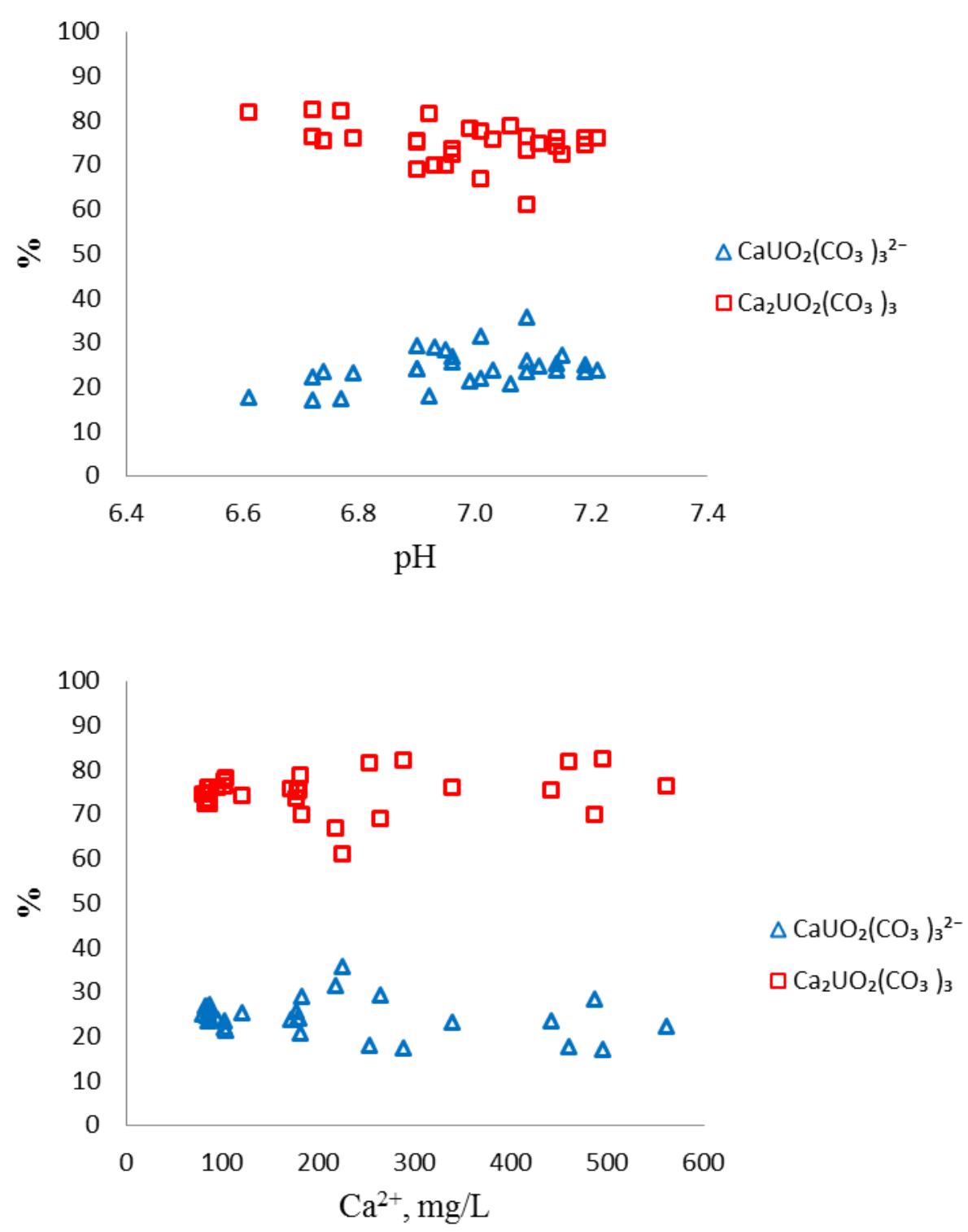

Figure 4.2 Speciation as a function of $\mathrm{pH}$ (top) and speciation against $\mathrm{Ca}^{2+}$ in the mixing zone of the Biscayne Aquifer (bottom). Dominance of $\mathrm{Ca}_{2} \mathrm{UO}_{2}\left(\mathrm{CO}_{3}\right)_{3}$ appears to decrease with increasing $\mathrm{pH}$ (opposite for $\mathrm{CaUO}_{2}\left(\mathrm{CO}_{3}\right)_{3}{ }^{2-}$ ) while a pattern of constancy is noted as a function of $\mathrm{Ca}^{2+}$. 

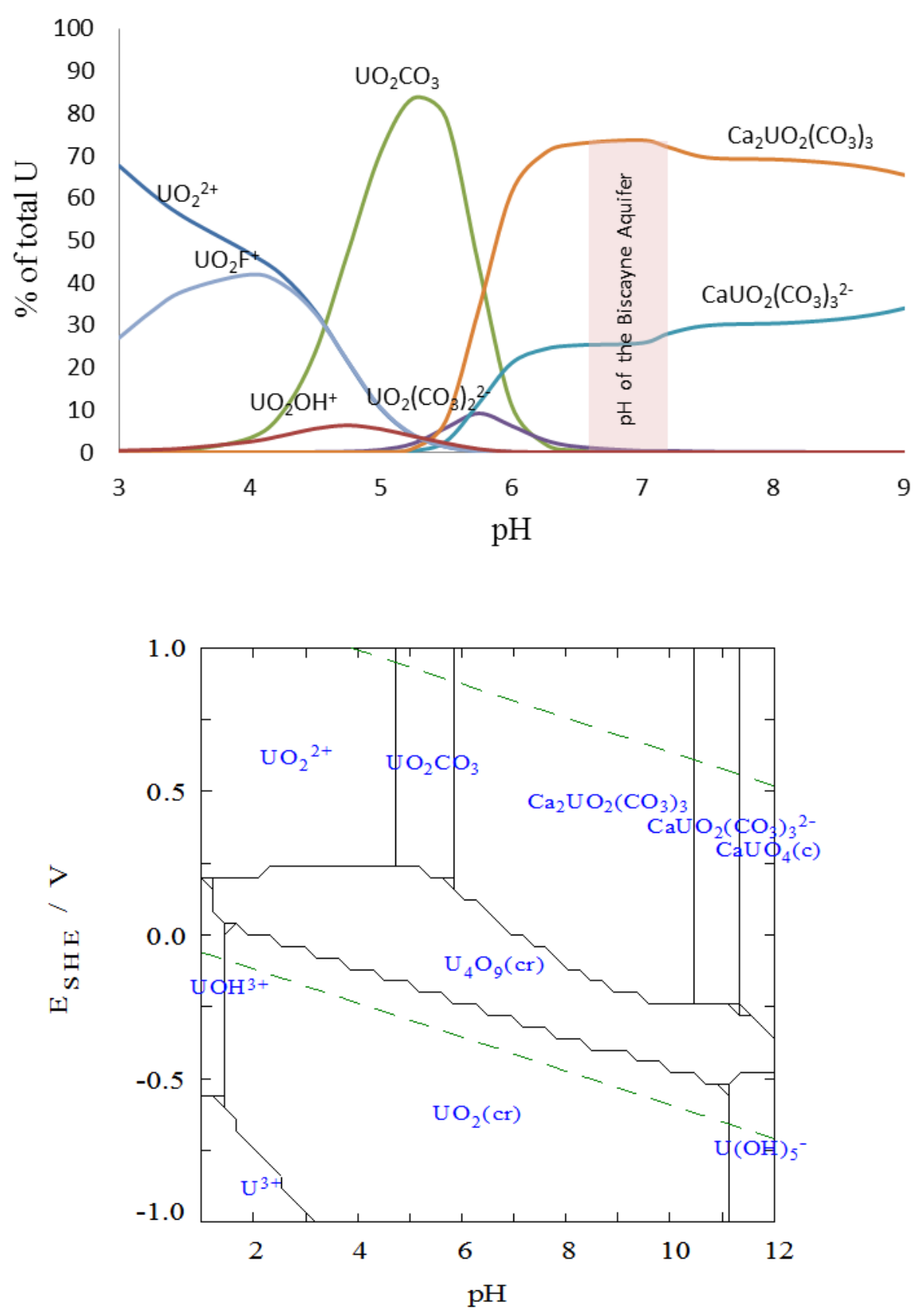

Figure 4.3 Theoretical speciation curves for freshwater of the Biscayne Aquifer (top) and Eh-pH diagram for aqueous species and solid phases of the Ca- $-\mathrm{O}_{2}-\mathrm{C}-\mathrm{H}_{2} \mathrm{O}$ system at $25^{\circ} \mathrm{C}$ (bottom). Eh-pH diagram drawn with MEDUSA (Puigdomenech, 2004) for average 'fresh' samples where $\mathrm{Cl}<200 \mathrm{mg} / \mathrm{L}$. $[\mathrm{U}]=1.29 \times 10^{-9} \mathrm{M},\left[\mathrm{CO}_{3}{ }^{2-}\right]=6 \times 10^{-3} \mathrm{M},[\mathrm{Ca}]=$ $2 \times 10^{-3} \mathrm{M}$ and ionic strength $=0.01 \mathrm{M}$. 
Calculated saturation indices show that all samples are undersaturated with respect to uranium minerals, such as uraninite, $\mathrm{U}_{4} \mathrm{O}_{9}$, schoepite and rutherfordine. This means dissolution of these minerals is possible if they exist in appreciable quantities. The very low $\mathrm{U}$ concentrations of the samples imply negligible dissolution of uranium minerals due to saltwater intrusion. Samples in the mixing zone are near saturation with calcite (section 3.5.2). Dissolution of calcite increases $\mathrm{Ca}^{2+}$ concentration in the solution and this may in turn result in increased concentrations of Ca-uranyl-carbonates. Since pH is buffered around 7, Ca-uranyl-cabonates dominate the speciation and calcite dissolution-precipitation may only influence the proportions of the two Ca-uranylcabonates (Figure 4.3).

\subsubsection{Mixing and speciation due to aquifer recharge (confined Upper Floridan aquifer)}

The native UFA water is sulfate-reducing with Eh of about $-179 \mathrm{mV}(\mathrm{pE}=-3.02)$. In speciation calculation using PHREEQC, the redox potential is adjusted for equilibrium between sulfide and sulfate (i.e., S (-2) / S (6)). Speciation of the native UFA aquifer water (Figure 4.4) is similar to the average Biscayne Aquifer water (Figure 4.3) for neutral to alkaline $\mathrm{pH}$. Here calcium-uranyl carbonates dominate for $\mathrm{pH}$ greater than 6.5. On average, $\mathrm{Ca}_{2} \mathrm{UO}_{2}\left(\mathrm{CO}_{3}\right)_{3}$ accounts for $53 \%$ and $\mathrm{CaUO}_{2}\left(\mathrm{CO}_{3}\right)_{3}{ }^{2-}$ accounts for $45 \%$ of the species. At lower $\mathrm{pH}$ of 3.5 to $6.5, \mathrm{UO}_{2}{ }^{+}$appears dominant for the reduced UFA water.

During ASR, mixing of recharge and native waters results in a mixture with different $\mathrm{pH}$ and concentration of ions. Figure 4.5 shows changes in total $\mathrm{U}$ concentration, $\mathrm{pH}$ and $\mathrm{pE}$ as functions of the fraction of recharge. $\mathrm{U}$ decreases linearly with recharge towards its concentration in the recharge water. $\mathrm{pH}$ and $\mathrm{pE}$ vary non- 
linearly with percent of recharge; $\mathrm{pH}$ gradually decreases while $\mathrm{pE}$ increases towards their corresponding values in the recharge water at $100 \%$. Due to the non-linear relations of $\mathrm{pH}$ and $\mathrm{pE}$ to recharge, fractions of dominant $\mathrm{U}$ species may not be linearly related to recharge. U speciation due to mixing between the groundwater and recharge water is shown in Figure 4.6 at recharge increments of $20 \%$. pH of the resulting mixtures are near neutral varying between 7.48 at $20 \%$ recharge and 7.76 at $80 \%$ recharge. Thus $\mathrm{Ca}_{2} \mathrm{UO}_{2}\left(\mathrm{CO}_{3}\right)_{3}$ dominates the speciation of mixtures and the percentage decreases with recharge. $\mathrm{CaUO}_{2}\left(\mathrm{CO}_{3}\right)_{3}{ }^{2-}$ remains the second dominant species at a constant percentage of about $44 \%$ in all mixtures. The percentages of $\mathrm{UO}_{2}\left(\mathrm{CO}_{3}\right)_{2}{ }^{2-}$ become appreciable at higher recharges of $60 \%$ and $80 \%$ where the mixture $\mathrm{pH}$ corresponds to the peak of $\mathrm{UO}_{2}\left(\mathrm{CO}_{3}\right)_{2}{ }^{2-}$ curve in Figure 4.4. The results of mixing seem to be sufficiently represented by Figure 4.4 implying that the mixture $\mathrm{pH}$ plays a major role in speciation. If the mixture is equilibrated with calcite, a common mineral in carbonate aquifers, $\mathrm{pH}$, Ca and alkalinity increase due to dissolution of calcite. The increased concentrations favor formation of more $\mathrm{Ca}_{2} \mathrm{UO}_{2}\left(\mathrm{CO}_{3}\right)_{3}$ while $\mathrm{CaUO}_{2}\left(\mathrm{CO}_{3}\right)_{3}{ }^{2-}$ decreases when compared to mixing only. The native groundwater is in equilibrium with calcite, thus the difference between simple mixing and one with calcite equilibrium is seen at higher recharge (Table 4.4). The percent of $\mathrm{Ca}_{2} \mathrm{UO}_{2}\left(\mathrm{CO}_{3}\right)_{3}$ increases by $8 \%$ and $14 \%$ (at $60 \%$ and $80 \%$ recharge, respectively) because mixing and equilibrium result in higher calcium and carbonate concentrations while $\mathrm{pH}$ is buffered at a narrow range of 7.76 to 7.8. Speciation appears insensitive to $\mathrm{U}$ concentration in both the recharge and native waters. Assuming the recharge water contains higher $\mathrm{U}$ concentrations of $30 \mu \mathrm{g} / \mathrm{L}$ had no effect on the dominant species and their percentages in the mixture. Similarly, increasing $U$ 
concentration in the native water ten-fold did not change the speciation. It may be said that U(VI) mobilization and adsorption in the carbonate Upper Floridan aquifer can be explained in terms of the fate of $\mathrm{Ca}_{2} \mathrm{UO}_{2}\left(\mathrm{CO}_{3}\right)_{3}$ and $\mathrm{CaUO}_{2}\left(\mathrm{CO}_{3}\right)_{3}{ }^{2-}$ as they dominate its speciation. Even at higher U concentrations of about $30 \mu \mathrm{g} / \mathrm{L}$, the speciation may imply that the groundwater is non-toxic to cells (Prat et al., 2009).

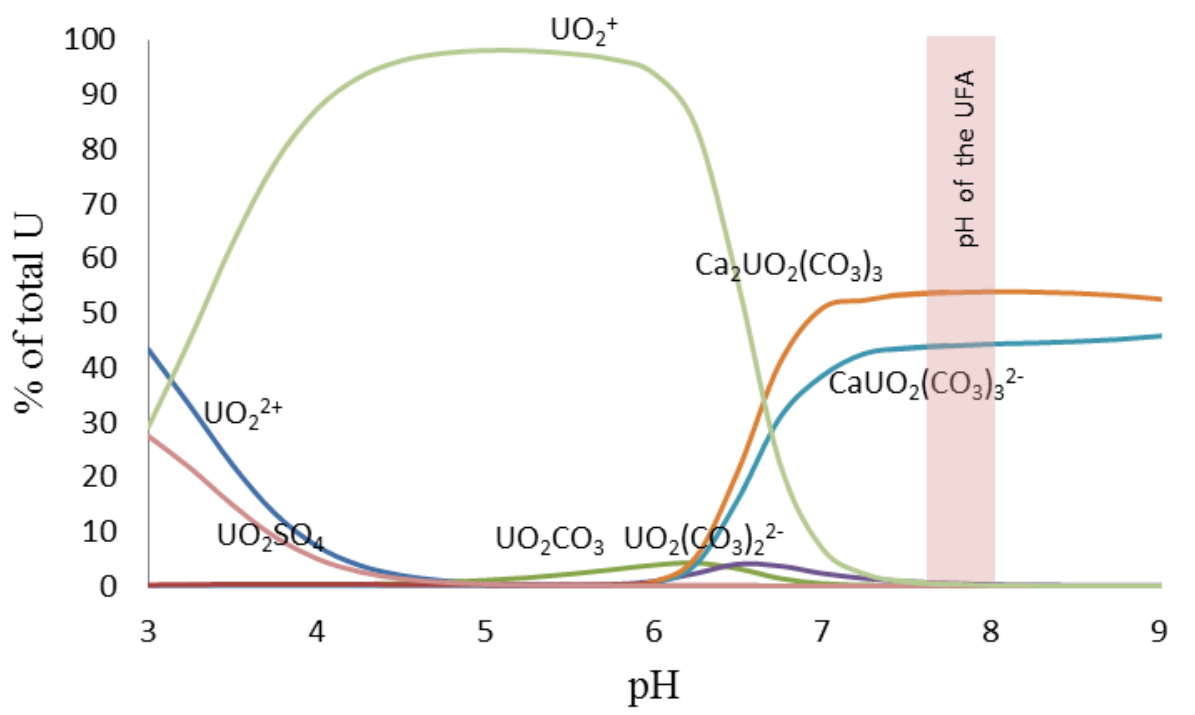

Figure 4.4 Theoretical speciation of native UFA water at KRASR. 


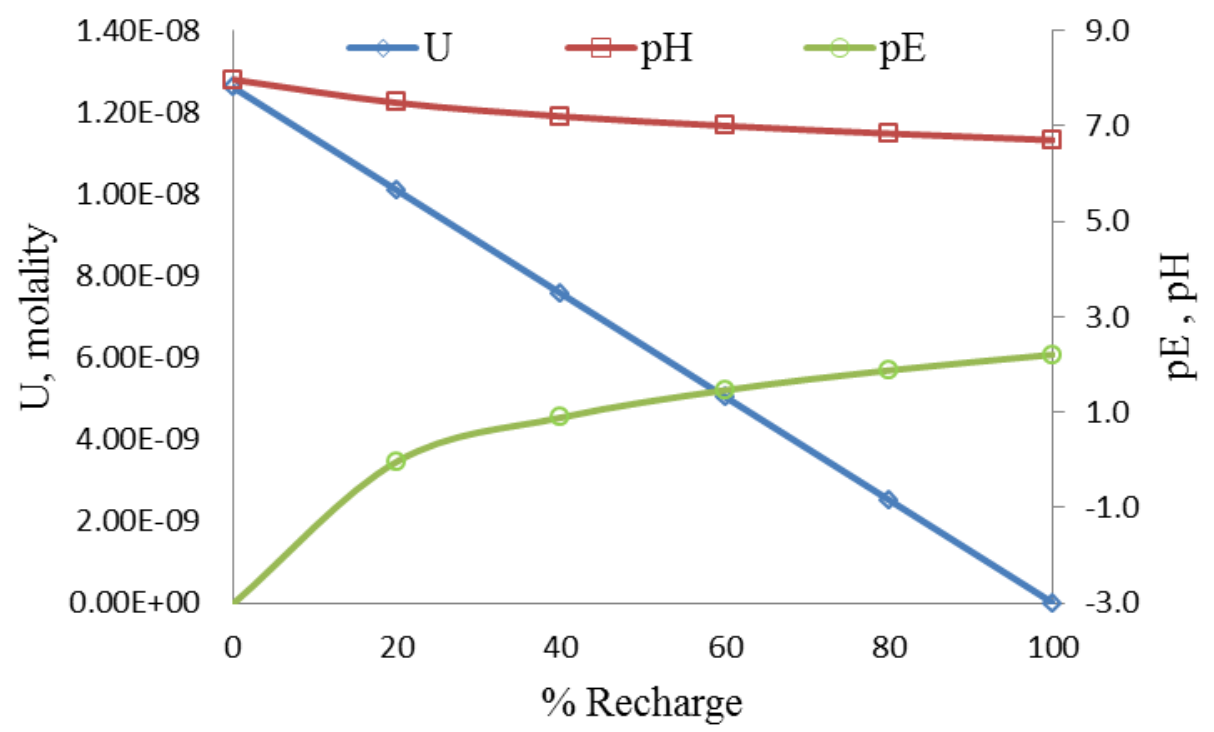

Figure 4.5 Variations of $\mathrm{U}, \mathrm{pH}$ and $\mathrm{pE}$ with fraction of recharge.
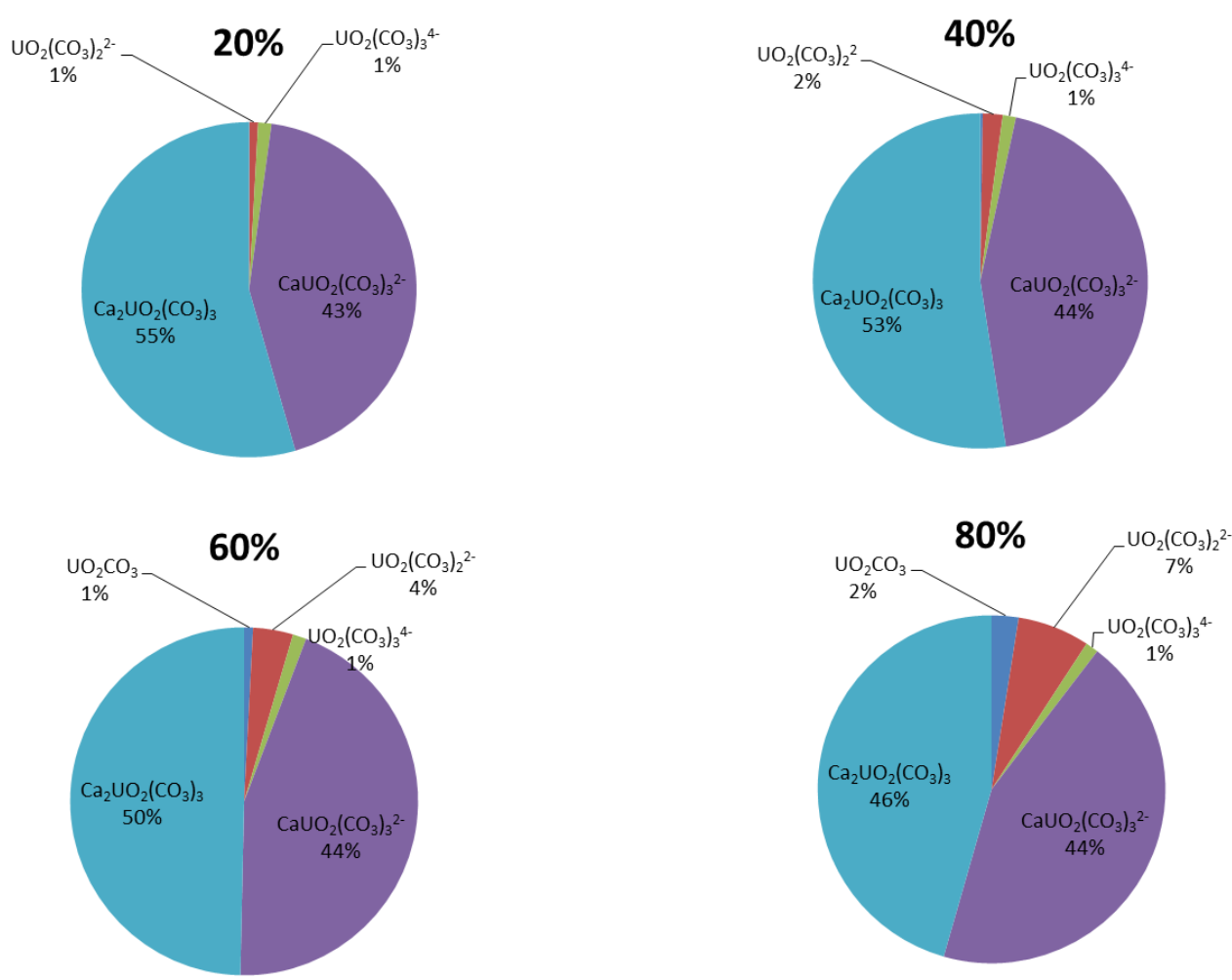

Figure 4.6 Dominant species in mixtures of UFA water and recharge water. Bold percentages are fractions of recharge water in the mixture. 
Table 4.4 Effect of equilibrium with calcite (Equil.) compared to mixing only (Mix). Native aquifer $[\mathrm{U}]=3 \mu \mathrm{g} / \mathrm{L}$

\begin{tabular}{llllllllll}
\hline \% Recharge & \multicolumn{3}{c}{20} & \multicolumn{2}{c}{40} & & 60 & \multicolumn{2}{c}{80} \\
& \multicolumn{2}{c}{ Mix } & Equil. & Mix & Equil. & Mix & Equil. & Mix & Equil. \\
\hline pH & 7.48 & 7.80 & 7.20 & 7.79 & 7.00 & 7.78 & 6.84 & 7.76 \\
Log $\left(\mathrm{pCO}_{2}\right)$ & -2.4 & -2.7 & -2.2 & -2.7 & -2.0 & -2.7 & -1.9 & -2.7 \\
$\mathrm{Ca}(\mathrm{mmol} / \mathrm{L})$ & 1.03 & 1.10 & 0.90 & 1.10 & 0.76 & 1.02 & 0.62 & 0.97 \\
Alkalinity & & & & & & & & \\
$($ mmol/L) & 1.88 & 2.02 & 1.72 & 2.05 & 1.55 & 2.07 & 1.39 & 2.09 \\
$\mathrm{CaUO}_{2}\left(\mathrm{CO}_{3}\right)_{3}{ }^{2-}$ & 43.0 & 42.3 & 42.5 & 41.4 & 39.3 & 40.4 & 31.5 & 39.0 \\
$\mathrm{Ca}_{2} \mathrm{UO}_{2}\left(\mathrm{CO}_{3}\right)_{3}$ & 54.0 & 56.2 & 50.5 & 57.1 & 43.8 & 58.4 & 32.6 & 59.9 \\
\hline
\end{tabular}

\subsection{Conclusion}

Groundwater mixing driven by saltwater intrusion and aquifer recharge changes water quality parameters like $\mathrm{pH}$ and ionic concentrations. U speciation appears most sensitive to changes in $\mathrm{pH}$ and calcium-uranyl carbonates dominate in neutral to alkaline $\mathrm{pH}$ ranges. In carbonate aquifers, $\mathrm{pH}$ is usually buffered around 7 and the speciation exhibits domination of Ca-uranyl carbonates $\left(\mathrm{Ca}_{2} \mathrm{UO}_{2}\left(\mathrm{CO}_{3}\right)_{3}\right.$ and $\left.\mathrm{CaUO}_{2}\left(\mathrm{CO}_{3}\right)_{3}{ }^{2-}\right)$. $\mathrm{Ca}_{2} \mathrm{UO}_{2}\left(\mathrm{CO}_{3}\right)_{3}$ constitutes more than $61 \%$ of the species in the mixing zone of the Biscayne Aquifer followed by $\mathrm{CaUO}_{2}\left(\mathrm{CO}_{3}\right)_{3}{ }^{2-}$ which constitutes upto $36 \%$. Similar to the Biscayne Aquifer, $\mathrm{U}$ speciation at the KRASR site is dominated by $\mathrm{Ca}_{2} \mathrm{UO}_{2}\left(\mathrm{CO}_{3}\right)_{3}$ for all fractions of mixing. Equilibrium of the mixtures with calcite increased the percentage of $\mathrm{Ca}_{2} \mathrm{UO}_{2}\left(\mathrm{CO}_{3}\right)_{3}$ complex by up to $14 \%$ at recharge fraction of $80 \%$. Increasing $\mathrm{U}$ concentrations in the recharge and native waters up to and beyond the current guideline value (i.e., $30 \mu \mathrm{g} / \mathrm{L}$ ) appeared not to change the dominance of calciumuranyl carbonates.

Fate and toxicity of $\mathrm{U}$ in carbonate aquifers may be explained in terms of $\mathrm{Ca}_{2} \mathrm{UO}_{2}\left(\mathrm{CO}_{3}\right)_{3}$ 
and $\mathrm{CaUO}_{2}\left(\mathrm{CO}_{3}\right)_{3}{ }^{2-}$ as they dominate its speciation around the neutral $\mathrm{pH}$. As has been reported in some human studies, predominance of Ca-uranyl carbonates may imply nontoxicity of drinking water supplies even when $\mathrm{U}$ concentrations exceed drinking water guidelines. Understanding this, speciation is also important to effectively select most appropriate water supply treatment trains and to address posed challenges. For instance, during membrane treatment of $\mathrm{U}$, membrane fouling is minimal when Ca-uranylcarbonates are the dominant species. Results from this study are applicable to other similar carbonate aquifers. Thus, in addition to total $\mathrm{U}$ concentration, $\mathrm{U}$ speciation is very important in the development of fate and transport models, risk assessment, and the appropriate selection of treatment trains for groundwater supplies.

\section{References}

Arthur, J., Dabous, A. and Fischler, C. (2007). Aquifer storage and recovery in Florida: geochemical assessment of potential storage zones. In Management of Aquifer Recharge for Sustainability. Proceedings of the 6th International Symposium on Managed Aquifer Recharge of Groundwater, Acacia Publishing, Phoenix. , pp. 185197.

Arthur, J.D. and Cowart, J.B. (2001). Florida aquifer storage and recovery geochemical study: Year three progress report. Florida Geological Survey Open File Report, p.83.

Bernhard, G., Geipel, G., Reich, T., Brendler, V., Amayri, S. and Nitsche, H. (2001). Uranyl (VI) carbonate complex formation: Validation of the $\mathrm{Ca}_{2} \mathrm{UO}_{2}\left(\mathrm{CO}_{3}\right)_{3}$ (aq.) species. Radiochimica Acta, 89(8); pp.511.

Bradner, A., McPherson, B.F., Miller, R.L., Kish, G. and Bernard, B. (2005). Quality of Ground Water in the Biscayne Aquifer in Miami-Dade, Broward, and Palm Beach Counties, Florida, 1996-1998, with Emphasis on Contaminants. US Geol. Surv. Open-File Rep. 2004-1438.

Brown, C.J., Jurgens, B.C., Katz, B.G., Landon, M.K. and Eberts, S.M. (2007). Arsenic and uranium in four aquifer settings: occurrence, distribution, and mechanisms for transport to supply wells. In Proceedings of the 2007 National Groundwater 
Association Naturally Occurring Contaminants Conference: Arsenic, Radium, Radon, and Uranium, Charleston, South Carolina; pp. 15.

Curtis, G.P., Davis, J.A. and Naftz, D.L. (2006). Simulation of reactive transport of uranium (VI) in groundwater with variable chemical conditions. Water Resour. Res., 42(4).

Davis, J.A., Meece, D.E., Kohler, M. and Curtis, G.P. (2004). Approaches to surface complexation modeling of uranium (VI) adsorption on aquifer sediments. Geochim. Cosmochim. Acta 68(18); 3621-3641.

Dong, W. and Brooks, S.C. (2006). Determination of the formation constants of ternary complexes of uranyl and carbonate with alkaline earth metals (Mg2, Ca2 , Sr2, and Ba2 ) using anion exchange method. Environ. Sci. Technol., 40(15); 4689-4695.

Guillaumont, R. and Mompean, F.J. (2003). Update on the Chemical Thermodynamics of Uranium, Neptunium, Plutonium, Americium and Technetium. Amsterdam: Elsevier.

Hem, J.D. (1985). Study and interpretation of the chemical characteristics of natural water. US Geol. Surv. Water-Suppl. Pap. 2254.

Jurgens, B.C., Fram, M.S., Belitz, K., Burow, K.R. and Landon, M.K. (2010). Effects of groundwater development on uranium: Central Valley, California, USA. Ground Water, 48(6); 913-928.

Kurttio, P., Salonen, L., Ilus, T., Pekkanen, J., Pukkala, E. and Auvinen, A. (2006). Well water radioactivity and risk of cancers of the urinary organs. Environ. Res., 102(3); 333-338.

Mirecki, J.E., Bennett, M.W. and López-Baláez, M.C. (2012). Arsenic Control During Aquifer Storage Recovery Cycle Tests in the Floridan Aquifer. Ground Water, 51(4); 539-549.

Nair, S. and Merkel, B.J. (2011). Impact of alkaline earth metals on aqueous speciation of Uranium (VI) and sorption on quartz. Aquat. Geochem., 17(3); 209-219.

Norrström, A.C. and Löv, Å (2014). Uranium theoretical speciation for drinking water from private drilled wells in Sweden-implications for choice of removal method. Appl. Geochem., 51; 148-154.

Parkhurst, D.L. and Appelo, C. (2013). Description of input and examples for PHREEQC version 3: a computer program for speciation, batch-reaction, one-dimensional transport, and inverse geochemical calculations. US Geol. Surv. Techniques and Methods, book 6, chap. A-43. 
Prat, O., Vercouter, T., Ansoborlo, E., Fichet, P., Perret, P., Kurttio, P. and Salonen, L. (2009). Uranium Speciation in Drinking Water from Drilled Wells in Southern Finland and Its Potential Links to Health Effects. Environ. Sci. Technol., 43(10); 3941-3946.

Prinos, S.T., Wacker, M.A., Cunningham, K.J. and Fitterman, D.V. (2014). Origins and Delineation of Saltwater Intrusion in the Biscayne Aquifer and Changes in the Distribution of Saltwater in Miami-Dade County, Florida. US Geol. Surv. Scient. Invest. Rep. 2014-5025.

Puigdomenech, I. (2004). Hydra/Medusa chemical equilibrium database and plotting software. KTH Royal Institute of Technology.

Rossiter, H.M.A., Graham, M.C. and Schäfer, A.I. (2010). Impact of speciation on behaviour of uranium in a solar powered membrane system for treatment of brackish groundwater. Separation and Purification Technology, 71(1); 89-96.

Schulze, R. and Merkel, B. (2012). Sorption of Uranium on Iron Coated Sand in the Presence of Arsenate, Selenate, and Phosphate. In B. Merkel and M. Schipek, Eds., The New Uranium Mining Boom. : Springer; 573-578.

Seldén, A.I., Lundholm, C., Edlund, B., Högdahl, C., Ek, B., Bergström, B.E. and Ohlson, C. (2009). Nephrotoxicity of uranium in drinking water from private drilled wells. Environ. Res., 109(4); 486-494.

Stalder, E., Blanc, A., Haldimann, M. and Dudler, V. (2012). Occurrence of uranium in Swiss drinking water. Chemosphere, 86(6); 672-679. 


\section{ANALYSIS OF WATER QUALITY IN THE FLORIDAN AQUIFER SYSTEM}

\subsection{Abstract}

The Floridan Aquifer System (FAS) consists of the Upper Floridan Aquifer (UFA), Middle confining unit (MC) and Lower Floridan Aquifer (LF). The UFA is the aquifer commonly used for ASR in South Florida and a basic understanding of the aquifer water quality is necessary to understand changes due to ASR. Ionic analyses and mineral saturation index computations were used to infer determinants of water quality in the FAS on a regional scale. Groundwater samples were obtained from CERP's RFGW project and included a combination of monitoring, production and recharge wells. Salinity and constituent concentrations generally increased with depth and resulted mainly from mixing of recharge water with seawater. Most samples were saturated with calcite and dolomite and these minerals had the tendency to precipitate. Dissolution of gypsum in deeper aquifers was predicted based on SI of gypsum in the FAS samples.

\subsection{Introduction and method}

The Floridan Aquifer System (FAS) consists of the Upper Floridan Aquifer (UFA), Middle confining unit (MC) and Lower Floridan Aquifer (LF) (Reese and AlvarezZarikian, 2007). In the UFA, calcite and dolomite are the major minerals with some local gypsum. Calcite is the most abundant where the stoichiometric calcite $\left(\mathrm{CaCO}_{3}\right)$ is highly significant compared to low magnesium calcite $\left(\mathrm{Ca}_{0.96} \mathrm{Mg}_{0.04} \mathrm{CO}_{3}\right)$, which makes less than $0.1 \%$ by weight of the FAS rocks (Katz, 1992). Dolomite accounts about $8 \%$ of rocks in the UFA but its percentage is much higher below the UFA. Major ion concentrations vary with depth and degree of confinement of the aquifer where they generally increase with depth and degree of confinement. In South Florida, where the 
aquifer is confined, the increases in ion concentration with depth is related to mixing of freshwater and residual seawater. Samples from the UFA in South Florida are usually at or near saturation with respect to calcite. In the recharge areas of west-central Florida, however, the samples are undersaturated with calcite because the aquifer is recharged so rapidly that the water doesn't have enough contact time with calcite to get saturated. Ca$\mathrm{HCO}_{3}$ water is common in the freshwater areas of the aquifer where calcite dissolution reaction occurs. Ca-Mg- $\mathrm{HCO}_{3}$ facies are also observed in some freshwater parts of the aquifer in which case $\mathrm{Mg}$ is added to the water from dissolution of dolomite and magnesium-rich clay minerals.

Changes in major ions (i.e., $\mathrm{Ca}^{2+}, \mathrm{Mg}^{2+}, \mathrm{K}^{+}, \mathrm{Na}^{+}, \mathrm{Cl}^{-}$and $\mathrm{SO}_{4}{ }^{2-}$ ) in the UFA are tested by modeling mixing between fresh and saltwater samples. Water quality data are obtained from the Regional Floridan Groundwater Monitoring (RFGW) project which is also associated with the ASR regional study for CERP. The dataset is available in the DBHYDRO database (South Florida Water Management District, 2015). The RFGW project was created to generate data to help build a variable density groundwater flow model for ASR purposes of the CERP. Samples from more than 40 monitoring wells in South Florida are used from the year 2007 which contains larger number of sample locations than later years. Freshwater composition is taken as average of the dilute samples $\left(\mathrm{Cl}^{-}<30 \mathrm{mg} / \mathrm{L}\right)$ while typical saltwater composition is used to represent the seawater end member. The carbonate groundwater is mixed with saltwater in proportions varying from 0 to $100 \%$ in the mixtures. PHREEQC calculates the concentration in mixtures by multiplying the concentration of each element in each solution with its mixing fraction, summing these numbers, and dividing by the sum of mixing fractions. 
The mixing fraction is given by equation 3.1. The model calculates the change of ionic concentrations and saturation indexes as a function of ionic strength caused by seawater in the mixture.

Table 5.1: Average compositions of the freshwater and saltwater end members used in the modeling

\begin{tabular}{|c|c|c|}
\hline Water quality & FAS & SW \\
\hline Temperature & 26 & 25 \\
\hline $\mathrm{pE}$ & -5.1 & 13 \\
\hline DO & 1 & 8 \\
\hline $\mathrm{pH}$ & 7.9 & 8 \\
\hline $\mathrm{Na}^{+}$ & 6 & 10500 \\
\hline $\mathrm{K}^{+}$ & 1.8 & 390 \\
\hline $\mathrm{Ca}^{2+}$ & 42.3 & 410 \\
\hline $\mathrm{Mg}^{2+}$ & 12.8 & 1350 \\
\hline $\mathrm{Cl}^{-}$ & 8.2 & 19000 \\
\hline $\mathrm{SO}_{4}{ }^{2-}$ & 96.8 & 2700 \\
\hline Alkalinity & 76.7 & 142 \\
\hline
\end{tabular}

Concentrations are in mg/l; Temperature in degrees Celcius; $\mathrm{pH}$ and $\mathrm{pE}$ are unitless 
Geochemical processes responsible for observed water quality in the FAS may be inferred from ionic deltas and calculation of saturation indices (Appelo and Postma, 2010; Appelo, 1994; Bear et al., 1999; Ghiglieri et al., 2012; Gimenez and Morell, 1997; Kouzana et al., 2009; Price and Herman, 1991; Russak and Sivan, 2010). Major-ion concentrations for every sample were compared with ideal freshwater-saltwater mixing lines, which are functions of saltwater fraction in the mixture. Assuming chloride is conservative, the fraction of saltwater in a sample was determined based on its chloride content (equation 3.2). Ionic deltas were then calculated using equation 3.3. PHREEQC was used to calculate the SI of the samples as well as the SI for theoretical mixing between the FW and SW end members. The wells used in this study are combination of monitoring, production and injection wells. They are located in South Florida, mostly along the east and west coast with some wells located around Lake Okeechobee. They are open to various depths tapping the UFA, MC and LFA. This allows comparison of processes in the different aquifers.

\subsection{Analysis of major ions}

The samples were linearly correlated with salinity $\left(\mathrm{R}^{2} \geq 0.9\right.$ for $\mathrm{Na}^{+}, \mathrm{K}^{+}, \mathrm{Mg}^{2+}$; $\mathrm{R}^{2}=0.81$ and 0.86 for $\mathrm{Ca}^{2+}$ and $\mathrm{SO}_{4}{ }^{2-}$ respectively). This implies that the mixture water quality is mostly due to mixing between freshwater and saltwater with some geochemical reactions that especially seem to affect $\mathrm{Ca}^{2+}$ and $\mathrm{SO}_{4}{ }^{2-}$. 


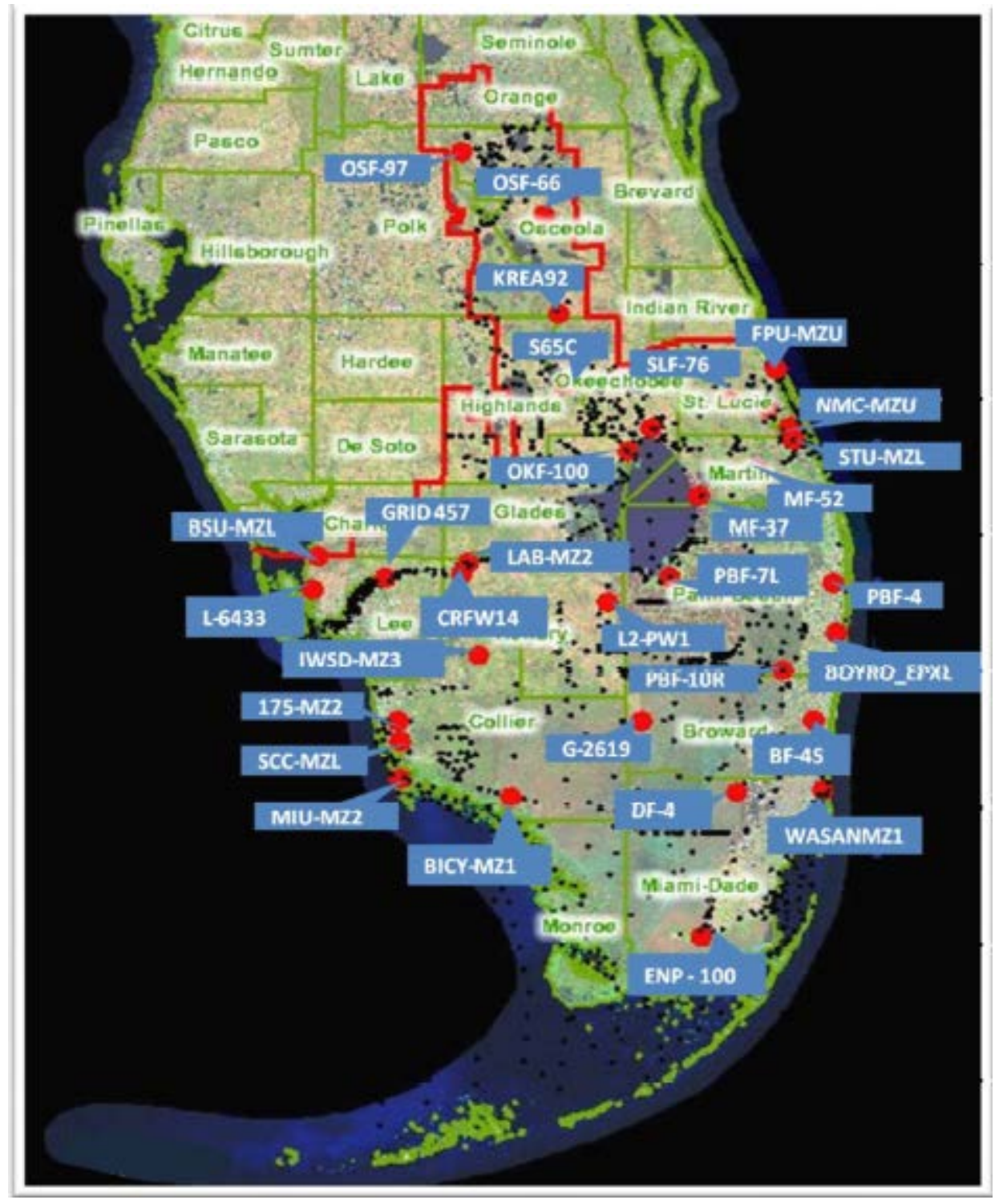

Figure 5.1 Location of FAS monitoring wells in the region covered by SFWMD (from DBHYDRO) 
Samples from the Lower Floridan (LF) aquifer have very high salinity in excess of $10,000 \mathrm{mg} / \mathrm{L}$ chloride and reaching up to $19,000 \mathrm{mg} / \mathrm{L}$ (i.e., the chloride content of seawater). This is typical of the salinity in the LF, which is believed to be due to residual seawater. Based on vertical variations of salinity, the FAS can be divided into three salinity zones. In order of increasing depth, these are: brackish water zone, transition zone and salinity zone (Reese, 1994). Reese (1994) defined the transition zone to be between $5240 \mathrm{mg} / \mathrm{L}$ of chloride and 18,900 $\mathrm{mg} / \mathrm{L}$ of chloride. The higher chloride concentration is similar to chloride concentration in seawater. The base of the brackish water zone lies in the UFA along the coast but extends into the middle confining unit further inland. Salinity changes rapidly with depth in the transition zone due to diffusion from the saline interface at lower zones. Salinity of the brackish zone could be residual or due to lateral intrusion but upwelling of saline water from the Boulder zone into the UFA is unlikely because water in the Boulder zone water is denser than water in the brackish zone for all expected temperatures (Reese, 1994). Flushing of the brackish UFA water by meteoric water is difficult given the confined nature of the UFA in South Florida. Incomplete flushing from upgradient areas of the invaded seawater results in higher salinities. Thus a general increase of salinity with depth is observed in the UFA in South Florida.

Most wells in the RFGW project did not show temporal changes of chloride concentrations in the past decade. One well tapping the LF, however, showed a sudden increase of $\mathrm{Cl}^{-}$from 1500 to 18,000 mg/L in 2008 (Figure 5.2). This well is located close to the coast in Palm Beach County and migration of salty water may be the cause. Other 
monitoring wells in the same location tapping the UF and MC didn't show the sudden change of chloride concentrations.
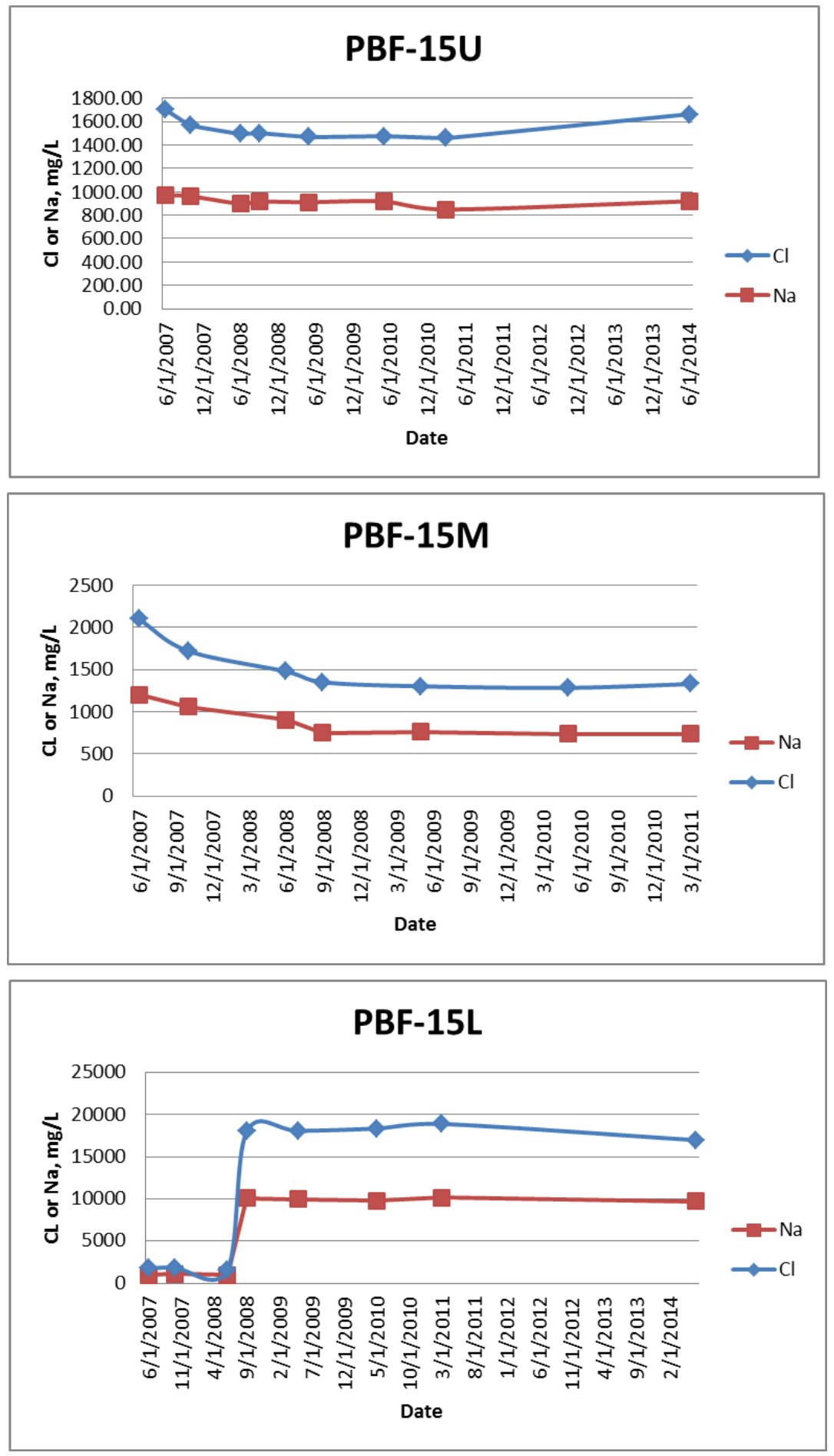

Figure 5.2 Increased $\mathrm{Na}$ and $\mathrm{Cl}^{-}$at well PBF-15 (upper, middle and lower aquifers) 
In the simulation, freshwater is taken as average of the dilute water samples $(\mathrm{Cl}<$ $30 \mathrm{mg} / \mathrm{L}$ ) while typical saltwater composition is used to represent the seawater end member. Ionic deltas and theoretical mixing line for the major ions are shown in Figure 5.3. $\mathrm{pH}$ is predicted to be around 8 by the mixing model. At higher salinity, the sample $\mathrm{pH}$ values were lower than the simulated values possibly due to the addition of $\mathrm{CO}_{2}(\mathrm{~g})$ by microbial activities and ion exchange reactions. Some of the $\mathrm{Ca}^{2+}$ released by ion exchange may react with $\mathrm{HCO}_{3}{ }^{-}$resulting in $\mathrm{CaCO}_{3}$ precipitation and release of $\mathrm{CO} 2(\mathrm{~g})$ and thus lowering the $\mathrm{pH}$ according to the carbonate dissolution equation (equation 1.9). Likewise, microbial reduction of sulfate may increase $\mathrm{HCO}_{3}{ }^{-}$driving the dissolution reaction (equation 1.9) to the left. Some samples at lower salinity have $\mathrm{pH}$ higher than predicted due to dissolution reactions that consume $\mathrm{CO}_{2}(\mathrm{~g})$ and raise the $\mathrm{pH}$.

Most of the $\mathrm{Ca}^{2+}$ in the Floridan aquifer is a result of mixing between freshwater and saltwater. $\mathrm{Ca}^{2+}$ is found in excess of the mixing line and thus additional sources of $\mathrm{Ca}^{2+}$ may exist. The principal sources of $\mathrm{Ca}^{2+}$ are dissolution of calcite, dolomite and gypsum. Similar to $\mathrm{Cl}^{-}$, a significant increase of $\mathrm{Ca}^{2+}$ is seen with depth in the FAS which indicates the majority of $\mathrm{Ca}^{2+}$ originates from mixing with seawater. The concentration of $\mathrm{Ca}^{2+}$ is additionally controlled by calcite dissolution and some ion exchange may exist with $\mathrm{Mg}^{2+}$ (which is depleted from most samples in Figure 5.3). 

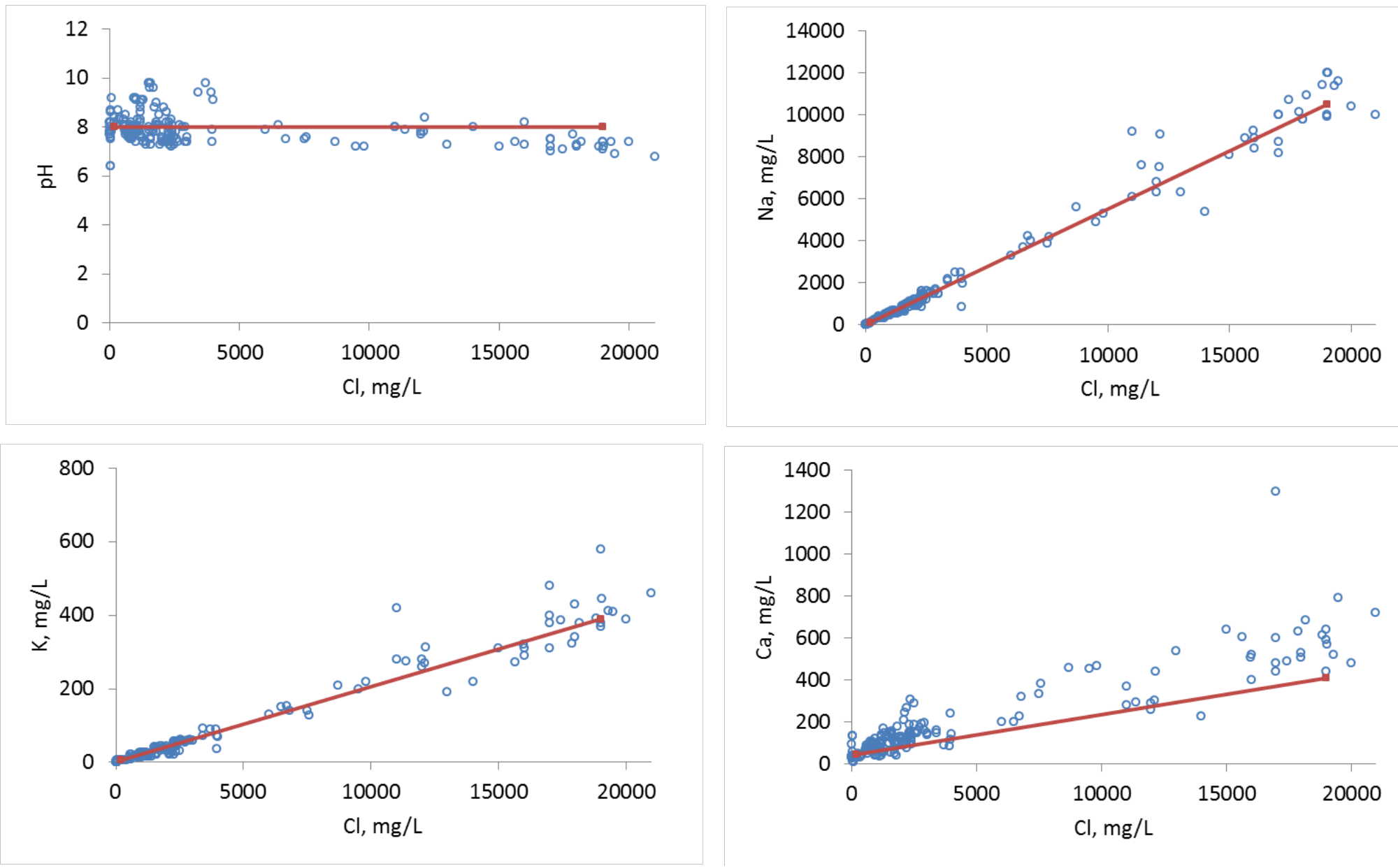

Figure 5.3. Ionic deltas for FAS samples (open circles) of RFGW project collected in the year 2007. Red lines are concentrations from simulated mixing between freshwater and saltwater. 

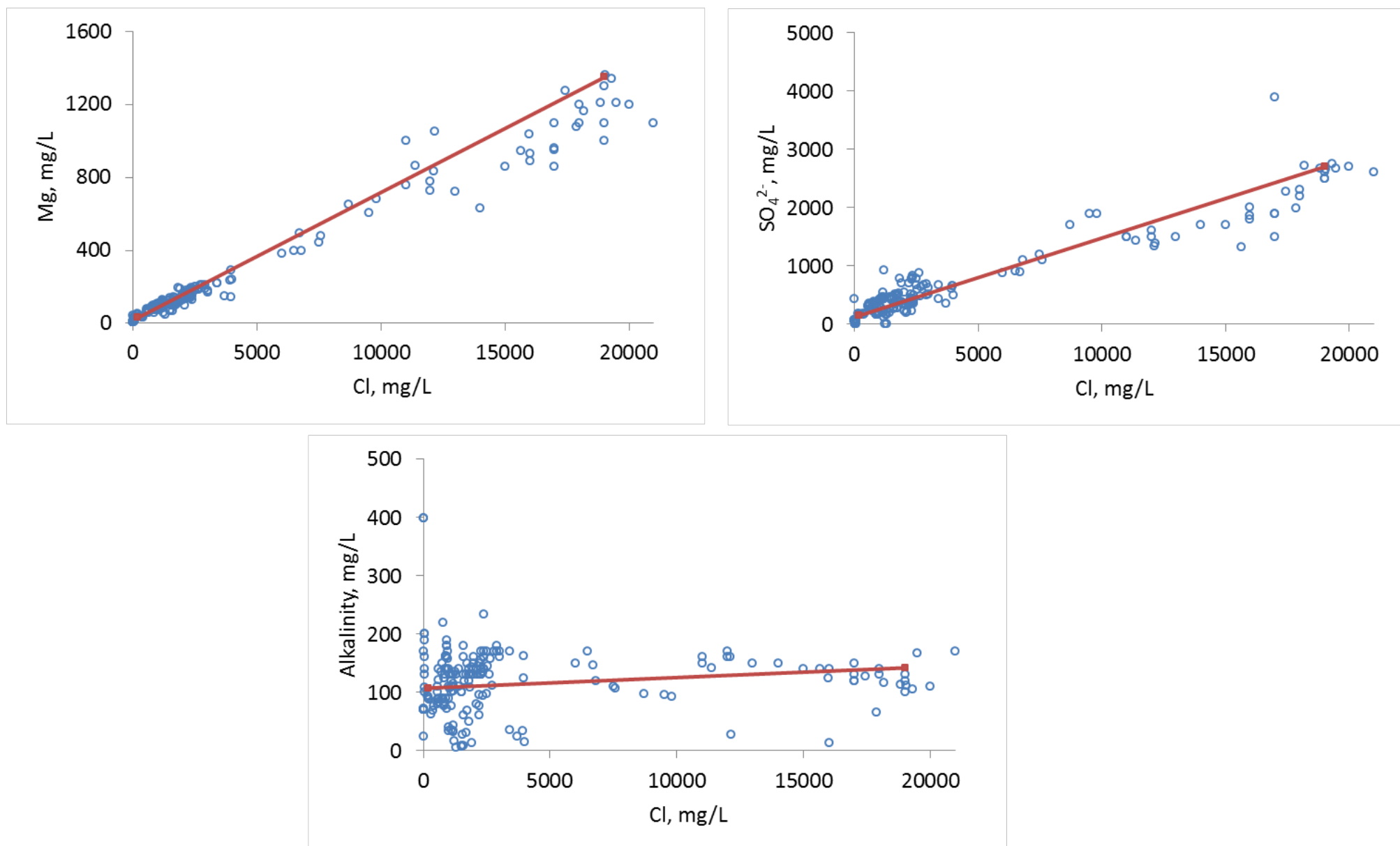

Figure 5.3 (continued). Ionic deltas for FAS samples (open circles) of RFGW project collected in the year 2007. Red lines are concentrations from simulated mixing between freshwater and saltwater. 
The higher $\mathrm{Ca}^{2+}$ concentration in the lower parts of the FAS could be due to gypsum dissolution which is very likely in FAS. In the UFA, the higher $\mathrm{Ca}^{2+}$ may be attributed to dissolution and upward leakage of gypsum from deeper aquifers. Cation exchange may be significant only in areas with large quantities of clays. It is difficult to distinguish $\mathrm{Ca}^{2+}$ from mineral source or cation exchange reaction solely based on the mixing line.

$\mathrm{Mg}^{2+}$ in the fresher parts of the aquifer (i.e., UFA) follows the theoretical mixing line. Thus mixing of fresh and saltwater determines the $\mathrm{Mg}^{2+}$ concentration in the UFA. In deeper parts (i.e., higher salinity), $\mathrm{Mg}^{2+}$ appears depleted compared to the theoretical mixing line. The depletion of $\mathrm{Mg}^{2+}$ in deeper parts of the aquifer can be due to precipitation (e.g., dolomite, magnesium calcite or magnesite) and cation exchange reactions that remove $\mathrm{Mg}^{2+}$ from solution.

Both $\mathrm{Na}^{+}$and $\mathrm{K}^{+}$generally plotted along the mixing line for up to $10,000 \mathrm{mg} / \mathrm{L}$ chloride. This is because the elements originate from mixing as there are only trace amounts of $\mathrm{Na}^{+}$and $\mathrm{K}^{+}$in principal minerals in the aquifer. Their concentrations increase with salinity and depth of the aquifer in South Florida. In this part of the state, recirculation of groundwater is slow and the remnant seawater has not been flushed, explaining the high $\mathrm{Na}^{+}$and $\mathrm{K}^{+}$concentrations in the aquifers.

Alkalinity $\left(\mathrm{HCO}_{3}{ }^{-}\right)$doesn't show clear pattern with chloride content. In fact, there is no significant relation of $\mathrm{HCO}_{3}{ }^{-}$with depth (Katz, 1992). Sources of bicarbonate alkalinity in water include equilibrium with $\mathrm{CO}_{2}$ in recharge areas that releases $\mathrm{HCO}_{3}{ }^{-}$by the calcite dissolution equation, dissolution of calcite and dolomite, and oxidation of organic matter by sulfate-reducing microorganisms. Dissolution of limestone in saltwater-freshwater mix zones may increase $\mathrm{HCO}_{3}{ }^{-}$concentrations and solubility of 
calcite controls both $\mathrm{Ca}^{2+}$ and $\mathrm{HCO}_{3}{ }^{-}$concentrations. The other sources of $\mathrm{HCO}_{3}{ }^{-}$are also significant contributors.

Like most of the other ions, sulfate $\left(\mathrm{SO}_{4}{ }^{2-}\right)$ concentration significantly increases with depth because saline waters are high in sulfate. Sulfate is in excess near the freshwater end while it is depleted near the saltwater end although a number of samples follow the mix line. Besides mixing, additional sources of sulfate include dissolution of gypsum (where it is locally present) and pyrite oxidation from overlying formations (Katz, 1992). Depletion of $\mathrm{SO}_{4}{ }^{2-}$ is most probably due to reduction of sulfate to HS-

\subsection{Mineral interactions}

Based on the mixing model of Figure 5.4, the mixtures would be saturated with calcite and dolomite for all fractions of saltwater in the mixture. This is observed for the majority of the samples whose calcite and dolomite SI values exceed zero. For most of the freshwater samples, SI values are higher than predicted by mixing, showing additional sources of calcite and dolomite for the solution. In accordance with the mineral composition of the UFA, calcite and dolomite dissolution and precipitation are expected. Calculated dolomite and calcite SI values for samples at higher salinity (LF or MC) are lower than predicted but they are oversaturated with the minerals. The magnitude of SI has no significance except that SI $<0$ indicates thermodynamic potential for dissolution

and SI $>0$ indicates potential for precipitation. Calcite is generally supersaturated for the UFA of South Florida where SI $>0$ for more than $10 \%$ mixing (Katz, 1992). Additionally, upward leakage of water containing dissolved gypsum from the deeper parts of the FAS can cause calcite oversaturation by the common ion effect (Katz, 1992). 
Thus deep wells which tap many zones of high permeability that could contain calciumsulfate water can be oversaturated with calcite due to mixing in the borehole.

Magnesite is predicted to be unsaturated up to about $8 \%$, after which it is supersaturated. Thus there is potential for dissolution at less than $8 \%$. Magnesite SI for the samples show mixed behavior below $8 \%$ where some are undersaturated while other samples are supersaturated. Local variation in availability of magnesite or other magnesium containing minerals may be the reason. At higher salt content $(>8 \%)$, the samples are oversaturated with magnesite as expected. Mixing with salt water which raises Mg concentrations can result in magnesite precipitation. 

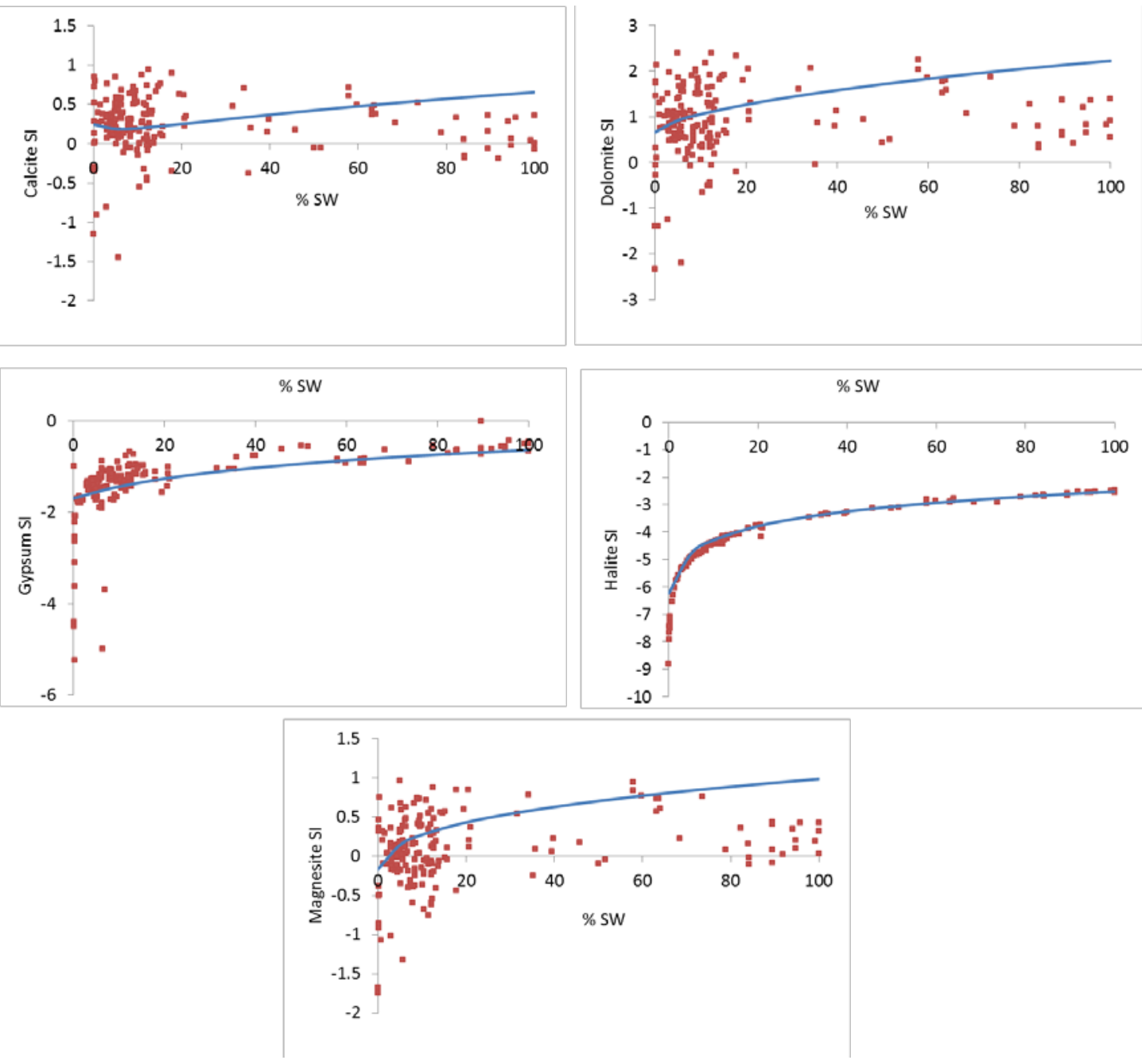

Figure 5.4. Mineral saturation indices in the FAS. Red dots are SI of the samples and the lines are SI for the simulated mixing between freshwater and saltwater at different fractions of saltwater. 
Gypsum SI is relatively well predicted by the model especially at high salinities. Gypsum is undersaturated at all saltwater fractions and there is a potential for its dissolution if it exists in the aquifers. At salinity less than $20 \%$, the sample SI are slightly higher than the model predicted values showing the presence of gypsum sources in those aquifers. Gypsum is found locally in the UFA in some parts of Florida (Katz, 1992). Other sources could be dedolomitization processes and dissolution of pyrite shown in equations 5.1 to 5.3 (Stumm and Morgan, 1996).

$$
\begin{gathered}
1.8 \mathrm{CaSO}_{4}+0.8 \mathrm{CaMg}\left(\mathrm{CO}_{3}\right)_{2}=1.6 \mathrm{CaCO}_{3}+\mathrm{Ca}^{2+}+0.8 \mathrm{Mg}^{2+}+1.8 \mathrm{SO}_{4}{ }^{2-} \\
\mathrm{FeS}_{2}+7 / 2 \mathrm{O}_{2}+\mathrm{H}_{2} \mathrm{O}=\mathrm{Fe}^{2+}+2 \mathrm{SO}_{4}{ }^{2-}+2 \mathrm{H}^{+} \\
\mathrm{FeS}_{2}+15 / 4 \mathrm{O}_{2}+7 / 2 \mathrm{H}_{2} \mathrm{O}=\mathrm{Fe}(\mathrm{OH})_{3}+2 \mathrm{SO}_{4}{ }^{2-}+4 \mathrm{H}^{+}
\end{gathered}
$$

The samples follow the model-produced SI line for halite which shows that halite originates from the saltwater and no rocks in the aquifer contain significant halite. Calculated SI of the samples with respect to aragonite, calcite, dolomite, halite, gypsum and magnesite $\left(\mathrm{MgCO}_{3}\right)$ have been compared with theoretical SI values of the minerals at different mixing fractions. The mixing model calculates SI solely based on the mixing fraction and doesn't take ion exchange effects into account. Thus model computed SI values may be used only as approximations of the potential of a mineral to dissolve or precipitate. Some wells had long open intervals and mixing may occur in the well bore. This may change the temperature, ionic strength, $\mathrm{pH}$ and concentration of dissolved gasses. Calculated SI values in the range \pm 0.5 can be assumed to indicate saturation, taking into account the uncertainties in the measurement of alkalinity and $\mathrm{pH}$ in the field and lab. Additionally, $\mathrm{CO}_{2}$ may be lost from the samples during transport to the lab. 


\subsection{Conclusions}

Incomplete flushing of residual seawater resulted in high salinity at the deeper FAS aquifers. The UFA is fresh to brackish with chloride concentrations below $5240 \mathrm{mg} / \mathrm{L}$, while salinity in LF can reach up to $19,000 \mathrm{mg} / \mathrm{L}$. Water quality in the UFA resulted mainly from mixing between recharge and seawater and ion concentrations generally increase as groundwater moves further away from recharge areas. Mineral interactions predicted were dissolution-precipitation of calcite and dolomite in the FAS aquifers and dissolution of gypsum from aquifers underlying the UFA.

\section{References}

Appelo, C.A.J. and Postma, D. (2010). Geochemistry, Groundwater and Pollution. Amsterdam, The Netherlands: Taylor \& Francis.

Appelo, C. (1994). Cation and proton exchange, $\mathrm{pH}$ variations, and carbonate reactions in a freshening aquifer. Water Resour. Res., 30(10); 2793-2805.

Bear, J., Cheng, A.H.D., Sorek, S., Ouazar, D. and Herrera, I. (1999). Seawater Intrusion in Coastal Aquifers - Concepts, Methods and Practices. The Netherlands: Kluwer Academic Publishers.

Ghiglieri, G., Carletti, A. and Pittalis, D. (2012). Analysis of salinization processes in the coastal carbonate aquifer of Porto Torres (NW Sardinia, Italy). J. Hydrol., 432; 4351.

Gimenez, E. and Morell, I. (1997). Hydrogeochemical analysis of salinization processes in the coastal aquifer of Oropesa (Castellon, Spain). Environ. Geol., 29 (1-2); 118131.

Katz, B.G. (1992). Hydrochemistry of the Upper Floridan aquifer, Florida. US Geological Survey Water-Resources Investigations Report 91-4196.

Kouzana, L., Mammou, A.B. and Felfoul, M.S. (2009). Seawater intrusion and associated processes: case of the Korba aquifer (Cap-Bon, Tunisia). C. R. Geosci., 341(1); 2135. 
Parkhurst, D.L. and Appelo, C. (2013). Description of input and examples for PHREEQC version 3: a computer program for speciation, batch-reaction, one-dimensional transport, and inverse geochemical calculations. US Geol. Surv. Techniques and Methods, book 6, chap. A-43.

Price, R.M. and Herman, J.S. (1991). Geochemical investigation of salt-water intrusion into a coastal carbonate aquifer: Mallorca, Spain. Geol. Soc. Am. Bull., 103 (10); 1270-1279.

Reese, R.S. (1994). Hydrogeology and the Distribution and Origin of Salinity in the Floridan Aquifer System, Southeastern Florida. : US Department of the Interior, US Geological Survey.

Reese, R.S. and Alvarez-Zarikian, C.A. (2007). Hydrogeology and aquifer storage and recovery performance in the Upper Floridan Aquifer, Southern Florida. Scientific Investigations Report 2006-5239.

Russak, A. and Sivan, O. (2010). Hydrogeochemical tool to identify salinization or freshening of coastal aquifers determined from combined field work, experiments, and modeling. Environ. Sci. Technol., 44(11); 4096-4102.

South Florida Water Management District (2015). DBHYDRO Browser, environmental monitoring.http://my.sfwmd.gov/dbhydroplsql/water_quality_interface.

station_select_2?v_project=RFGW\&v_js_flag=Y\&v_access_by=project 2015 last accessed on October 11, 2015.

Stumm, W. and Morgan, J. (1996). Aquatic chemistry, chemical equilibra and rates in natural waters. Environmental Science and Technology Series. 


\section{MODELING FLOW AND REACTIVE TRANSPORT OF ASR OPERATIONS IN THE UPPER FLORIDAN AQUIFER}

\subsection{Abstract}

Aquifer storage and recovery (ASR) provides an alternative water supply for long term water supply plans. In South Florida, the Upper Floridan Aquifer (UFA) is the aquifer used for storage during ASR. A conceptual and numerical reactive transport model was developed and calibrated for the Kissimmee River ASR (KRASR) site to evaluate and predict water quality changes during ASR in the carbonate UFA. The model was calibrated and used to predict concentrations of a comprehensive suite of major inorganic ions $\left(\mathrm{Na}^{+}, \mathrm{Cl}^{-}, \mathrm{Mg}^{2+}, \mathrm{K}^{+}, \mathrm{Ca}^{2+}, \mathrm{SO}_{4}{ }^{2-}\right.$ ), water quality parameters (alkalinity and $\mathrm{pH}$ ) and trace metals (Fe and As). Fate of As and Fe are studied because As has been recovered in concentrations exceeding the EPA standard of $30 \mu \mathrm{g} / \mathrm{l}$, and its release is associated with dissolution and precipitation of Fe oxides. Most of the major ions were well predicted by assuming conservative transport. Calcite dissolution-precipitation and cation exchange reactions were also included to better predict $\mathrm{Ca}$, alkalinity and $\mathrm{pH}$ measurements. A reaction network of geochemical reactions including thermodynamic equilibrium, surface complexation and kinetic reactions were included in the model to approximately simulate the fate of $\mathrm{Fe}$ and As. The reactive transport model was developed and calibrated by coupling PEST and PHAST codes and it successfully predicted observed water quality trends during cycle tests at the KRASR pilot site.

\subsection{Introduction to numerical simulation of ASR}

ASR is used to augment water supply by storing excess water during wet periods for use in times of water demand. The goal of ASR plants is to achieve maximum possible 
recovery without water quality deterioration. Numerical models can be used to simulate ASR scenarios and to estimate recovery efficiency (RE) as well as to predict water quality changes during the process. Some of the objectives of modeling ASR cycles are to:

- predict the effect of injection and withdrawal on groundwater levels or aquifer pressures;

- predict the effect of installing multiple wells that may create interference with one another;

- determine the effects of natural versus artificial recharge;

- determine the effects of boundary conditions of the model;

- determine the effect of hydraulic parameters (hydraulic conductivity, transmissivity, dispersion, dispersivity, etc.) on water quality and RE;

- predict the concentration of contaminants with time from source to the observation points; and

- determine the effects of retarding factors of contamination concentration (dilution, dispersion, adsorption, time-decay)

Reactive transport models coupling flow and transport codes are used to simulate ASR. Flow and transport models using finite-difference or finite-element methods may be used. The choice of scheme depends on the conceptual model requirements and available computer resources. But in general, finite-difference models (e.g., MODFLOW) are computationally more efficient than finite-element methods for a given problem. Finite-element models (e.g., FEFLOW) have the advantage that they can more closely represent irregular boundaries. SEAWAT (Guo and Langevin, 2002) is an example of a 
variable-density model based on MODFLOW (Harbaugh et al., 2000) and MT3DMS (Zheng and Wang, 1999), and can be used where density variations are significant. PHT3D (Prommer et al., 2003) couples MT3DMS with PHREEQC (Parkhurst and Appelo, 2013) and thus works within the MODFLOW scheme. PHAST (Parkhurst et al., 2004) is a publicly available reactive-transport model based on HST3D and PHREEQC. Thus both flow and chemistry input files are required in a PHAST modeling. The chemistry input file is identical to that of PHREEQC and it may be considered an extension of PHREEQC for 3D modeling. Data input for most of the models is not user friendly and graphic user interfaces (GUIs) simplify the pre-processing and postprocessing processes. Some of the widely used premiums GUIs are:

- Groundwater Vistas (Environmental Simulations Inc.)

- Groundwater Modeling System (Environmental Modeling Systems Inc.)

- Visual MODFLOW (Schlumberger Water Services)

- $\quad$ Processing MODFLOW for Windows (PMWIN)

- Argus Open Numerical Environments (Argus Holdings Ltd.)

- Several of the GUIs incorporate parameter estimation and optimization codes, such as UCODE (Poeter and Hill, 1998) and PEST (Doherty et al., 2010) to automate the calibration process (Table 6.1). 
Table 6.1 Summary of common flow and transport codes, GUIs and model calibration programs

\begin{tabular}{|c|c|c|c|c|c|c|c|}
\hline \multicolumn{2}{|l|}{ GUI } & \multirow{2}{*}{$\begin{array}{l}\mathrm{GV} \\
\mathrm{x}\end{array}$} & \multirow[t]{2}{*}{ GMS } & \multirow{2}{*}{$\begin{array}{l}\text { Visual } \\
\text { MODFLOW } \\
\mathrm{X}\end{array}$} & \multirow{2}{*}{$\begin{array}{l}\text { Argus } \\
\text { ONE }\end{array}$} & \multirow[t]{2}{*}{ PMWIN } & \multirow{2}{*}{$\begin{array}{l}\text { Description } \\
\text { 3D finite-difference, saturated flow } \\
\text { model developed by the USGS }\end{array}$} \\
\hline Flow & MODFLOW & & & & & & \\
\hline & FEMWATER & & $\mathrm{x}$ & & & & $\begin{array}{l}\text { 3D finite-element used to model density- } \\
\text { driven flow and transport in saturated and } \\
\text { unsaturated zones }\end{array}$ \\
\hline & HST3D & & & & & & $\begin{array}{l}\text { A flow model used by PHAST. PHAST } \\
\text { is a reactive transport code developed by } \\
\text { the USGS }\end{array}$ \\
\hline \multirow[t]{5}{*}{$\begin{array}{l}\text { Solute } \\
\text { Transport }\end{array}$} & MODPATH & $\mathrm{x}$ & $\mathrm{x}$ & $\mathrm{x}$ & $\mathrm{x}$ & & $\begin{array}{l}\text { A particle tracking code used with } \\
\text { MODFLOW }\end{array}$ \\
\hline & MT3DMS & $\mathrm{x}$ & $\mathrm{X}$ & $\mathrm{x}$ & $\mathrm{x}$ & $\mathrm{x}$ & $\begin{array}{l}\text { Simulation of multi species transport, } \\
\text { mainly by advection and dispersion }\end{array}$ \\
\hline & PHT3D & & & $\mathrm{x}$ & & $\mathrm{X}$ & $\begin{array}{l}\text { A reactive transport model that couples } \\
\text { PHREEQC and MODFLOW }\end{array}$ \\
\hline & SEAWAT & $\mathrm{x}$ & & $\mathrm{x}$ & $\mathrm{x}$ & & $\begin{array}{l}\text { Simulation of transient, variable-density } \\
\text { groundwater flow and transport. } \\
\text { SEAWAT couples MODFLOW and } \\
\text { MT3DMS }\end{array}$ \\
\hline & SUTRA & & & & & & $\begin{array}{l}\text { Saturated/unsaturated variable density } \\
\text { fluid flow and solute or energy transport }\end{array}$ \\
\hline \multirow[t]{2}{*}{ Calibration } & UCODE & $\mathrm{x}$ & $\mathrm{x}$ & & & $\mathrm{x}$ & $\begin{array}{l}\text { A universal inverse modeling code to } \\
\text { solve parameter estimation problems }\end{array}$ \\
\hline & PEST & $\mathrm{x}$ & $\mathrm{x}$ & $\mathrm{x}$ & & $\mathrm{x}$ & $\begin{array}{l}\text { A model-independent, non-linear } \\
\text { parameter estimator that is commonly } \\
\text { used in parameter estimation and } \\
\text { predictive analysis }\end{array}$ \\
\hline
\end{tabular}


Various flow and transport codes have been used to simulate ASR processes for estimation of RE and water quality changes. Misut and Voss (2007) used 3D SUTRA (Voss and Provost, 2010) to model impact of ASR on freshwater-saltwater transition zones in New York. Their simulations show gain from ASR when less water is recovered than injected in which case the net storage sets up a hydraulic saltwater intrusion barrier. Ward et al. (2008) simulated the effect of density-induced flow on RE of a hypothetical ASR system and concluded that RE was sensitive to density-induced flows. Petkewich et al. (2004) used PHAST to simulate ASR in Charleston, South Carolina. The authors included calcite dissolution-precipitation and cation exchange reactions and were able to reasonably simulate observed concentrations of major ions. Others have simulated mobilization of trace metals like Fe and As during ASR by using PHT3D (Greskowiak, 2006; Wallis et al., 2011) and PHREEQC (Antoniou et al., 2015; Antoniou et al., 2013). Reactive transport models are calibrated using observed concentrations from ASR cycle test data. Aquifer parameters, such as hydraulic conductivity and storage coefficient, are estimated from calibration and sensitivity analyses of drawdown or hydraulic heads. Transport parameters such as porosity and dispersivity are then estimated from calibration analyses of conservative ions. Finally, reaction parameters, such as initial mineral concentration and rates of reaction, are predicted from calibration of reactive elements. PEST (Doherty et al., 2010) is commonly used for automatic calibration because the program is model-independent and incorporates advanced optimization methods including regularization and singular value decomposition. 


\subsection{ASR in South Florida}

While many ASRs are experimental and are not currently in full operation in South Florida, they provide valuable information to support the feasibility study and planning of regional ASR projects (e.g., CERP). The USGS (Merritt, 1997) carried out a detailed density modeling of an experimental ASR in Hialeah, South Florida. The modeling was based on three cycle tests performed between 1975 and 1980 with the purpose of testing RE of ASR of potable water in the UFA. The USGS compiled data on ASR sites in southern Florida and produced a comprehensive evaluation of the sites (Reese, 2002;Reese and Alvarez-Zarikian, 2007). Reese and Alvarez-Zarikian (2007) studied ASRs in a number of counties in South and Central Florida. Four of the sites were in Miami-Dade County; namely Hialeah ASR (experimental and inactive), J.R. Dean (inactive), Southwest Wellfield (construction complete) and West Wellfield (operational testing or operating). Wells classified under operational or operational testing in Broward were Broward County WTP 2A, Fiveash WTP and Springtree WTP. Both the West and Southwest wellfields used water from the Biscayne Aquifer to recharge the UFA. Generally, the wells in Miami-Dade had sufficient RE. The Hialeah ASR and the West Wellfield are 'high' in recovery performance; Broward County WTP and Springtree are 'medium' while Five Ash is 'low' in RE. The studies mentioned above aimed at predicting RE and the cycle tests included a very limited ion and trace metal data for a few days; these data were collected mainly for regulatory purposes.

Many of the studies about ASR in South Florida focus on its feasibility in terms of recovery efficiency. Water quality changes and trace metal mobilization during ASR have been studied by Mirecki (2004) and Mirecki et al. (2012) as part of the 
Comprehensive Everglades Restoration Plan (CERP). Mirecki (2004) analyzed water quality changes in 11 treated surface-water ASRs in South Florida, including MDWASD West, Springtree and Fiveash sites. The analytes were dissolved oxygen (DO), nitrate and ammonia, sulfate, hydrogen sulfide, gross alpha radioactivity and radium isotopes, and total trihalomethanes. While most concentrations were within state and federal regulations, As and gross alpha recovered in Southwest Florida sometimes exceeded standards. Arsenic, fluoride, nitrate, nitrite, total trihalomethanes, radium isotopes, and gross alpha radioactivity have enforceable primary MCLs, while chloride, iron, manganese, and sulfate have non-enforceable secondary MCLs. Sulfate concentrations increase during the cycle tests but do not exceed the federal MCL of $250 \mathrm{mg} / \mathrm{L}$ (Mirecki, 2004). Microbe-mediated sulfate reduction to $\mathrm{H}_{2} \mathrm{~S}$ is possible during storage. In this regard, the geochemistry of sulfate is complex to quantify and it is necessary to be supported with isotopic measurements. Clogging of ASR is possible due to iron precipitation, which is common in ASR using oxygenated waters.

Different mechanisms could result in water quality changes during ASR (e.g., dissolution-precipitation reactions, oxidation-reduction reactions, cation exchange, etc.). It is thus not simple to pinpoint the controlling mechanism and extensive data may be required to calibrate and validate conceptual models. However, major ions are not analyzed consistently in experimental or operational ASRs and the cycle test data are usually incomplete with respect to major ions. Too few data from ASR and monitoring wells make estimation of reaction rates difficult. ASR tests are normally limited to quantifying recovery efficiency, addressing site-specific water quality issues and meeting 
federal and state permit requirements. The sampling is commonly not comprehensive to support calibration and validation effort; data collection also proves costly.

\subsection{Geochemical modeling at the Kissimmee River ASR (KRASR)}

\subsubsection{The KRASR pilot site}

Under the CERP, 330 ASR wells are proposed in South Florida. As part of the CERP pilot study, five pilot sites were constructed around Lake Okeechobee and in Hendry and Palm Beach Counties with the purpose of evaluating ASR feasibility at the respective locations. The Kissimmee River ASR (KRASR) is one of the five ASR pilot sites and is located at the intersection of the Kissimmee River and Lake Okeechobee. Water is stored in the UFA at depths between -543 and -856 feet below the National Geodetic Vertical Datum 1929 (NGVD29) (Mirecki et al., 2012). The KRASR has a comprehensive groundwater monitoring program for the purposes of evaluating water quality changes. The ASR well is evaluated and operated through a cyclic process, where each cycle includes periods of recharge, storage and recovery. To date, three cycle tests have been completed at the KRASR and a number of water quality parameters, major and trace ion concentrations have been monitored for each cycle.

KRASR has perhaps the most comprehensive data set for ASR geochemical modeling in the UFA of South Florida and the data is publicly available upon request. Data from KRASR was used in this chapter to assess the potential to predict fate of major ions and trace metals during ASR in Florida, which if successful, may be extended to similar carbonate environments. The dataset is used to calibrate and validate a conceptual model which includes advective-dispersive transport and reactions (equilibrium, kinetic, oxidation-reduction, dissolution-precipitation and cation exchange, among others). Flow 
and transport is modeled using PHAST. PHAST can reasonably be used for salinity less than $5000 \mathrm{mg} / \mathrm{L}$, which is the suggested threshold for buoyancy stratification (Petkewich et al., 2004). PHAST is herein selected because it is freely available and relatively convenient for reaction modeling because it uses normal PHREEQC input. The batch version of PHAST is used to allow coupling with PEST during calibration of the groundwater model.

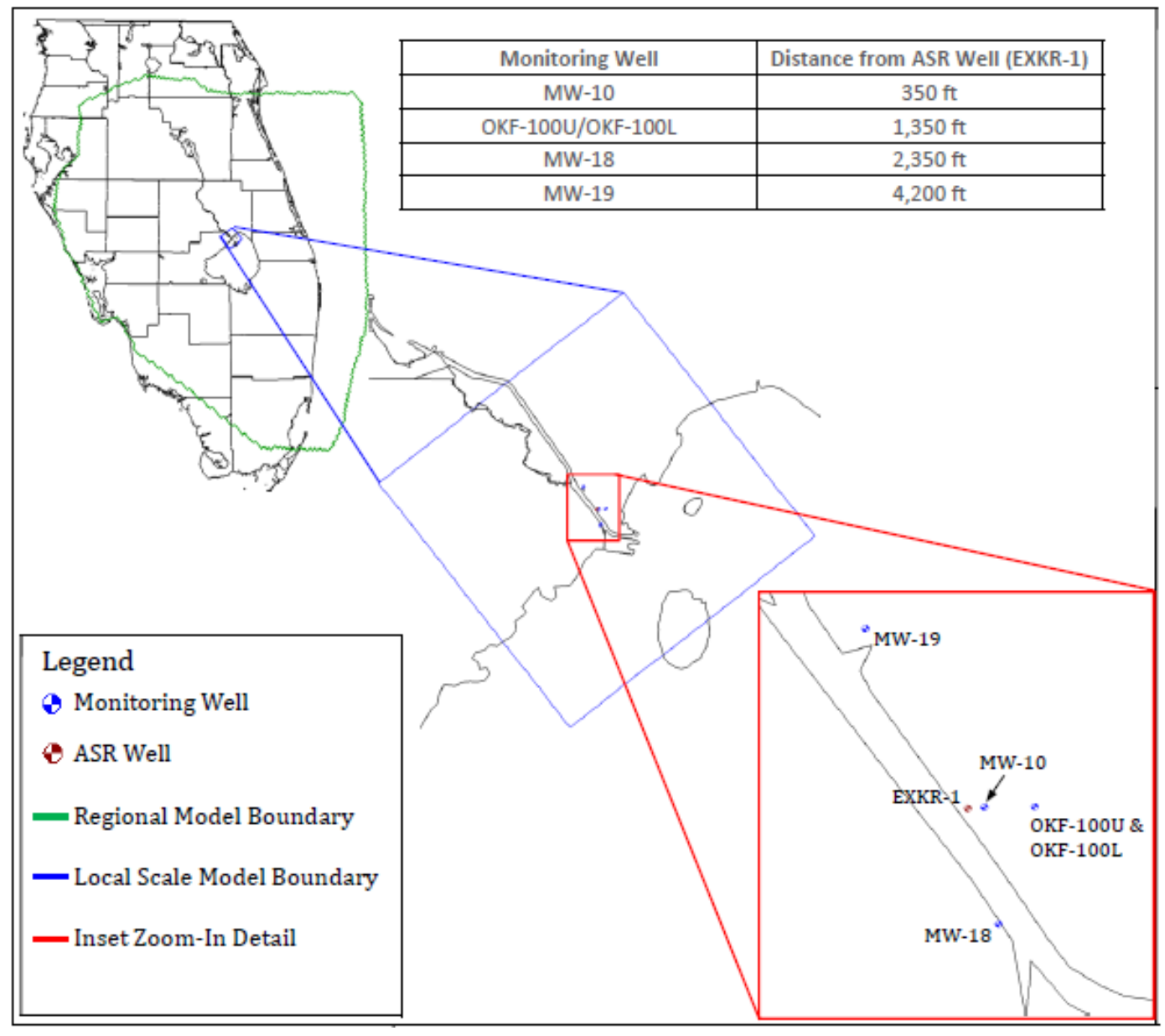

Figure 6.1. Local scale model (LSM) boundary and location of wells at the KRASR. Adapted from USACE (2012) 


\subsubsection{Inverse modeling}

Calculated SI (Mirecki et al., 2012) indicates calcite is slightly undersaturated or near equilibrium at MW-18 during cycle 3. No supersaturation is calculated for the samples. Calcite precipitation may thus be expected during some phases of the ASR operation. $\mathrm{CO}_{2}$ saturation is slightly above atmospheric for most samples at around -2.8. Samples are supersaturated for the iron minerals $\mathrm{FeS}$ and $\mathrm{FeS}_{2}$, while they are undersaturated for $\mathrm{FeOH}_{3}(\mathrm{a})$.

Native and recharge water qualities at both the ASR well and the monitoring well located at $1100 \mathrm{ft}$ from the ASR well are shown in Table 6.2. Total Fe is high at the end of storage in cycle 1 at the ASR well (Table 6.2). The recharge water has a higher Fe concentration while the native water has an insignificant concentration. End of storage and initial recovery data generally are similar at the ASR well. Recharge water has comparatively lower $\mathrm{pH}$ than the native water. $\mathrm{pH}$ at the end of storage of cycle 1 (i.e., 8.16) is higher than recharge or native groundwater owing to geochemical changes associated with the ASR. Calcite dissolution, for example, consumes $\mathrm{CO}_{2}$ giving more alkaline solution. The recharge water is unsaturated with all the minerals, except pyrite and goethite. The native water at the ASR is saturated with calcite, dolomite, pyrite and goethite, but unsaturated with the other minerals. The mixing could thus result in dissolution of calcite and dolomite but precipitation of pyrite and goethite in the aquifer. Cation exchange may also influence concentrations of major cations. By comparing recovered water samples and theoretical mixing lines, Ca appears to be released while $\mathrm{Na}, \mathrm{K}$ and $\mathrm{Mg}$ are depleted from solution (Figure 6.2). Excess Ca can be observed due to cation exchange as well as dissolution of calcite and dolomite. Recovered ionic deltas are 
largest during recovery in cycle 1 and approach the equilibrium mix line in successive cycles. Interestingly, many samples of recovered water in cycles 2 and 3 follow the mix line for all the cations except Ca (Figure 6.2); this may indicate that cation exchange reaches equilibrium and is minimal during successive cycles as long as no new aquifer material is exposed. Inverse modeling can be used to estimate the exchanging ions. In the current modeling, PHREEQC is used to estimate the reactions that give rise to recovered water at EXKR-1 from recharge and native waters. The fractions of mixing and mole transfers between phases are thus estimated. If we assume that $\mathrm{NaX}, \mathrm{KX}$ and $\mathrm{MgX}_{2}$ precipitate while $\mathrm{CaX}_{2}$ dissolves, the inverse model result in Table 6.4 shows exchange is between $\mathrm{Ca}$ and $\mathrm{Na}$ for water recovered at EXKR 1 (model 1) but exchange is between Ca and $\mathrm{K}$ for water stored at monitoring well OKF-100U just before recovery (model 2). In both models, excess $\mathrm{Ca}$ is mainly from calcite dissolution than from ion exchange. Uncertainty of $6 \%$ was assumed in the inverse model. The minimum uncertainty that can be used in inverse modeling is the maximum of charge percent error in each solution. Charge imbalance in the recovered and stored waters is less than $5 \%$ but it is $5.7 \%$ in the recharge water. The inverse modeling was thus performed with uncertainty of $6 \%$.

In summary, inverse geochemical modeling indicates that mixing and calcite dissolution along with limited cation exchange are sufficient to account for the evolution of injected water to recovered water at the ASR well. The recovered water at EXKR-1 can be explained as a mixture of $82 \%$ injected water and $18 \%$ ambient water. Additionally, approximately $0.43 \mathrm{mmol} / \mathrm{L}$ of calcite dissolved and Na exchanged for $\mathrm{Ca}$ from the exchanger. Thus $\mathrm{Ca}$ is released and $\mathrm{Na}$ is depleted from solution. The stored water as observed at OKF- $100 \mathrm{U}$ is $56 \%$ recharge and $44 \%$ native with approximately 
$0.21 \mathrm{mmol} / \mathrm{L}$ of calcite dissolved. Unlike the ASR well, it appears that Ca exchanges with $\mathrm{K}$ at OKF-100U. The inverse model shows calcite and pyrite dissolution and precipitation of $\mathrm{Fe}(\mathrm{OH})_{3}$. 
Table 6.2. Recharge and native water quality at the ASR (EXKR-1) well and at the monitoring well at $1100 \mathrm{ft}$. Water quality at the end of storage and recovery in cycle 1 are also shown.

\begin{tabular}{|c|c|c|c|c|c|c|c|c|c|c|c|c|c|c|c|}
\hline Description & $\mathrm{T}\left({ }^{0} \mathrm{C}\right)$ & $\mathrm{pH}$ & $\mathrm{pE}$ & DO & $\mathrm{Ca}^{2+}$ & $\mathrm{Mg}^{2+}$ & $\mathrm{Na}^{+}$ & $\mathrm{K}^{+}$ & $\mathrm{SO}_{4}{ }^{2-}$ & $\mathrm{Cl}^{-}$ & $\mathrm{F}^{-}$ & Si & $\begin{array}{l}\text { Alkalinity } \\
\text { as } \mathrm{HCO}\end{array}$ & $\mathrm{Fe}$ & As \\
\hline Recovered water at EXKR-1 & 19.07 & 7.72 & -2.4 & 0.12 & 4.1 & 11 & 39 & 4.8 & 57 & 67 & 0.27 & 2 & 107.4 & 0.27 & 0 \\
\hline Recharge water & 25.3 & 6.7 & 2.2 & 4.5 & 19.2 & 4.8 & 16.1 & 4 & 15.6 & 31.1 & 0 & 0 & 61 & 0.226 & 0.0009 \\
\hline Native water at $1100 \mathrm{ft}$ & 25.2 & 7.97 & -3 & 0.02 & 47 & 33 & 150 & 7.2 & 150 & 260 & 0 & 0 & 102.5 & 0.065 & 0.0016 \\
\hline Native water at EXKR-1 & 25.5 & 7.8 & -4.78 & 0.3 & 51.5 & 38.7 & 152 & 8.3 & 198 & 242 & 0 & 0 & 111 & 0.028 & 0 \\
\hline End of storage at ExKR-1 & 18.7 & 8.16 & -4.92 & 0.11 & 44 & 11 & 30 & 4.2 & 50 & 57 & 0.16 & 1.5 & 117.12 & 7.5 & 0 \\
\hline OF-100U stored before recove & 22.9 & 7.97 & -3.8 & 0.09 & 39 & 21 & 75 & 5.3 & 110 & 120 & 0.33 & 3.6 & 103.7 & 0.13 & 0 \\
\hline
\end{tabular}

All concentrations are in mg/L

Table 6.3. Computed saturation index of important minerals for the water compositions in Table 6.2

\begin{tabular}{|llllllll|}
\hline Description & Calcite & Dolomite & Halite & $\mathrm{CO}_{2(\mathrm{~g})}$ & Pyrite & $\mathrm{Fe}(\mathrm{OH})_{3}(\mathrm{a})$ & Goethite \\
\hline Recovered water at EXKR-1 & -0.10 & -0.50 & -7.14 & -2.66 & 14.26 & -2.95 & 2.73 \\
Recharge water & -1.52 & -3.30 & -7.85 & -1.82 & 18.81 & -1.15 & 4.75 \\
Native water at 1100 ft & 0.17 & 0.54 & -6.01 & -2.91 & 12.65 & -3.33 & 2.56 \\
Native water at EXKR-1 & 0.07 & 0.36 & -6.04 & -2.71 & 8.24 & -5.97 & -0.06 \\
\hline
\end{tabular}




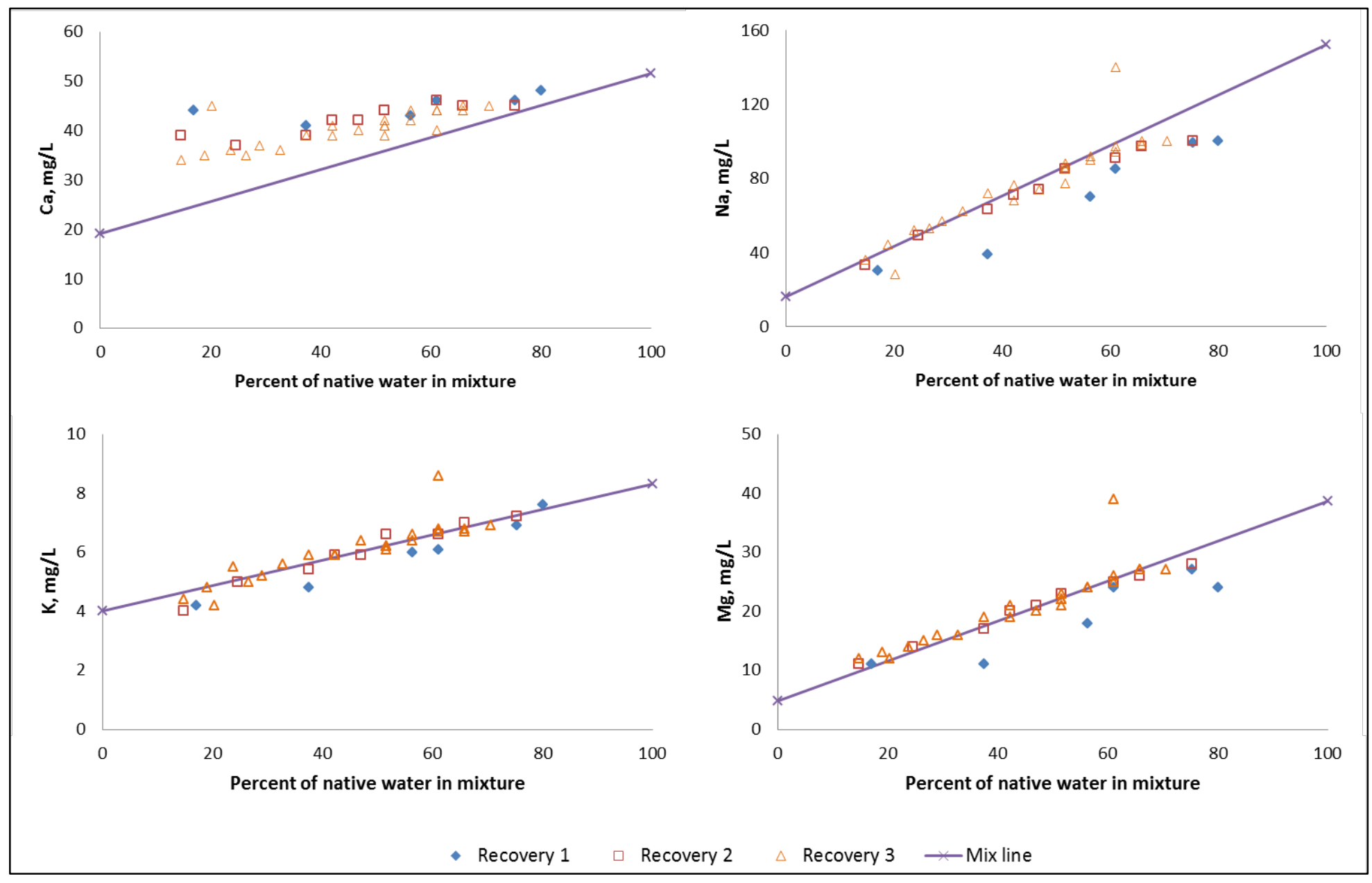

Figure 6.2 Ionic deviations from simple mixing at the ASR well during recovery of cycles 1-3. 
Table 6.4 Results of inverse modeling at KRASR

\begin{tabular}{cll}
\hline & Model 1 & Model 2 \\
\hline Solution fractions & & 0.56 \\
Recharge water & 0.82 & 0.44 \\
Native water at EXKR-1 & 0.18 & \\
Phase mole transfers (x10 $\left.{ }^{-4} \mathrm{~mol}\right)$ & & 2.10 \\
Calcite & 4.34 & 0.07 \\
$\mathrm{CaX} 2$ & 0.06 & -0.15 \\
$\mathrm{NaX}_{2}$ & -0.11 & -0.02 \\
$\mathrm{CO}_{2}(\mathrm{~g})$ & -0.36 & 0.31 \\
$\mathrm{Pyrite}$ & 0.43 & -0.32 \\
$\mathrm{Fe}(\mathrm{OH})_{3}(\mathrm{a})$ & -0.42 & 0.60 \\
$\mathrm{Quartz}$ & 0.33 &
\end{tabular}




\subsection{Reactive transport modeling of KRASR cycle tests}

\subsubsection{Conceptual model setup}

A draft local scale model (LSM) has been constructed for the KRASR from previous regional models to enable evaluation of drawdowns, recovery efficiency and wellfield operations (Figure 6.1). The LSM grid (48,000 ft x 48,000 ft) contains 28 layers, which comprise ten hydrogeological units. Aquifer properties and boundary conditions were estimated based on a SEAWAT simulation of the regional pumping scenario. The LSM estimated aquifer flow and transport parameters by calibrating the model to measured heads and total dissolved solids (TDS). Analyses of non-conservative water quality constituents were not within the scope of the report.

The present analysis focuses on reactive transport modeling of water quality constituents in the KRASR by zooming in a much smaller domain around the ASR. The domain is selected to represent the area around the ASR where water quality changes are expected during the cycle tests. The model domain is thus around the ASR well but not further than the monitoring well (MW 18) where measured water quality was not significantly affected by recharge (Mirecki et al., 2012). A square domain, $1800 \mathrm{ft}$ wide, is used and it is discretized into rectangular grids whose widths increase with distance from the well. Finer grids are used around the ASR and monitoring wells. The domain in Figure 6.4 is vertically discretized into a number of layers corresponding to the vertical cross section of the LSM (Figure 6.3). More layers are used to represent the UFA more accurately because it is the target storage zones, while fewer layers are used for the confining units. Figure 6.3 also shows the open intervals of each well. The ASR well and well MW-10 have long intervals intersecting the UFA and part of MC. OKF-100U has a 
short open interval intersecting the thin flow zone (FZ). Sampling at OKF-100L is from the APPZ zone. Since OKF-100U has a short open interval, water quality measurements from the wellhead may be assumed to represent samples within discrete intervals in the flow zone. On the other hand, MW-10 has a long interval and wellhead data at this well may be affected by mixing within the well bore. Stress periods are selected to reflect major changes in pumping namely injection, storage and recovery periods. For most of the stress periods, recharge and recovery rates are around 5 MGD. A nominal pumping rate is used during storage phases because PHAST requires that pumping at a well be different from zero. Average pumping rates and durations of the cycle tests at KRASR are shown in Table 6.5. 


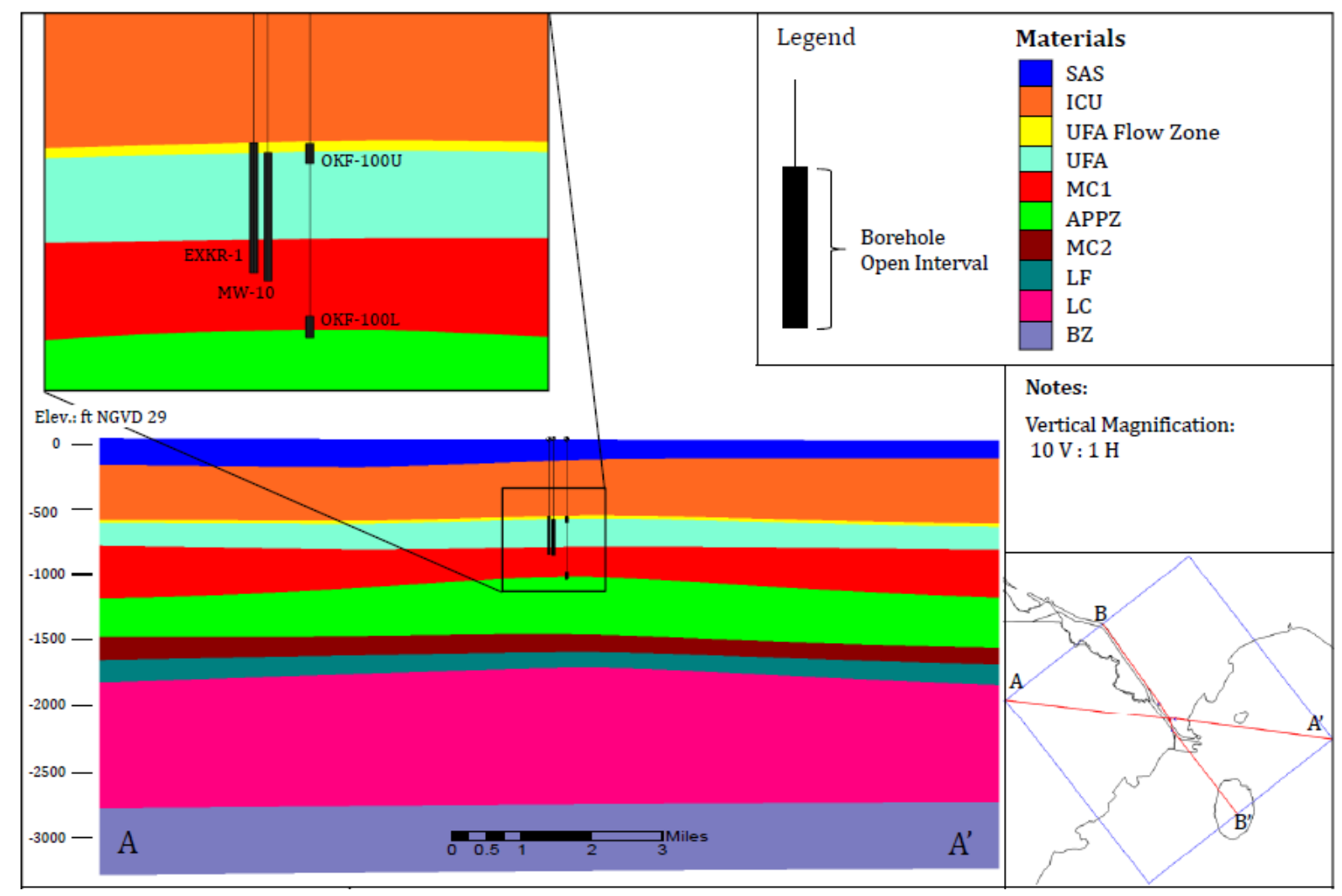

Figure 6.3 Hydrogeologic cross section of the KRASR system. EXKR-1 is the ASR well and the other wells are monitoring wells (USACE, 2012) 


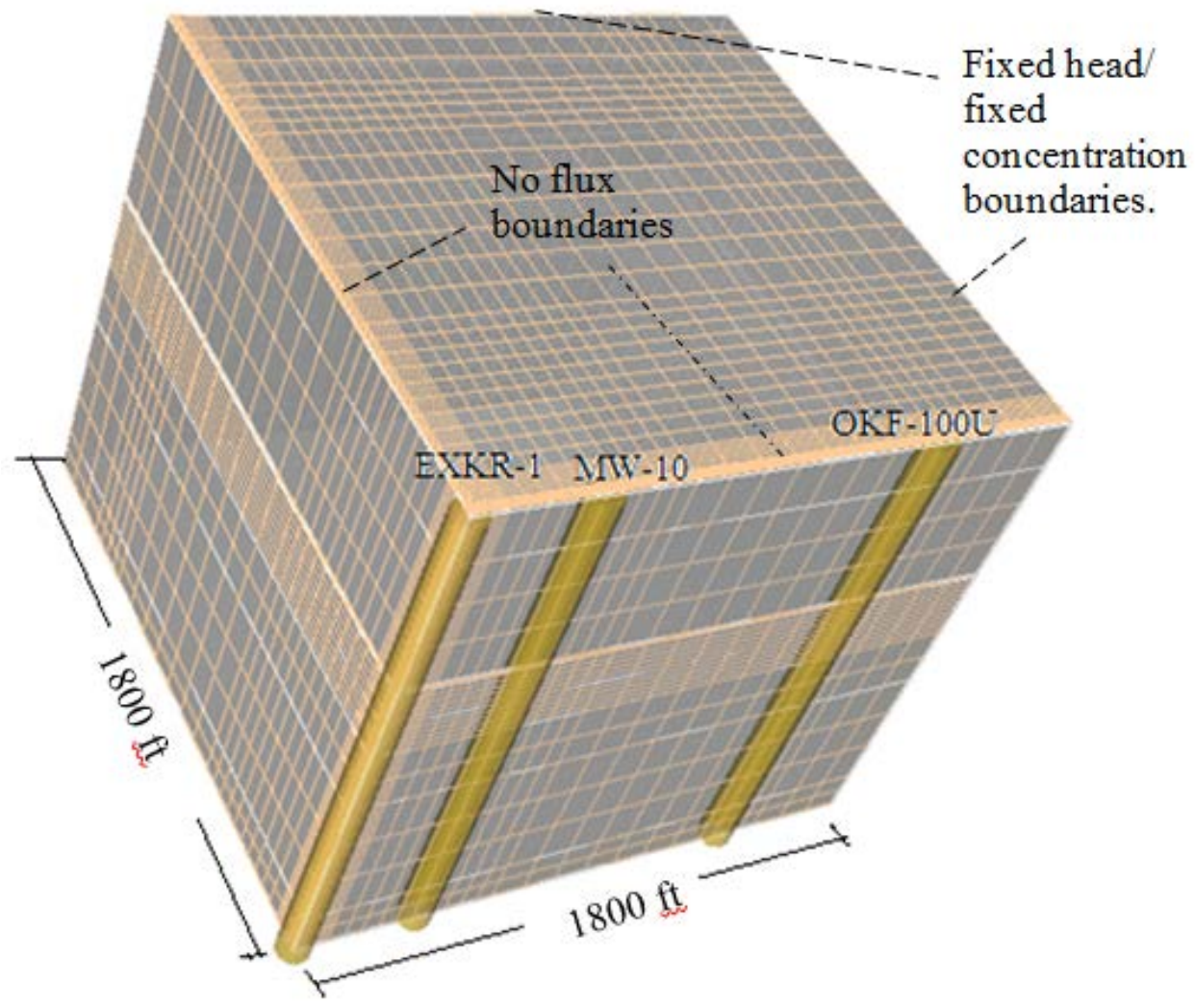

Figure 6.4 Model extent, discretization and boundary conditions for the reactive transport model 
Table 6.5 Average pumping rates and durations during KRASR cycle tests

\begin{tabular}{|c|c|c|c|c|}
\hline Phase & Start Date & End Date & No. of Days & Rate (MGD) \\
\hline \multicolumn{5}{|l|}{ Cycle 1} \\
\hline Recharge & 12-Jan-09 & 9-Feb-09 & 28 & 4.7 \\
\hline Storage & 9-Feb-09 & 9-Mar-09 & 28 & \\
\hline Recovery & 9-Mar-09 & 17-Apr-09 & 39 & 4.8 \\
\hline Inter-cycle & & & 24 & \\
\hline \multicolumn{5}{|l|}{ Cycle 2} \\
\hline Recharge & 11-Мау-09 & 28-Aug-09 & 109 & 3.8 \\
\hline Storage & 28-Aug-09 & 28-Oct-09 & 61 & \\
\hline Recovery & 28-Oct-09 & 2-Jan-10 & 66 & 4 \\
\hline Inter-cycle & & & 17 & \\
\hline \multicolumn{5}{|l|}{ Cycle 3} \\
\hline Recharge & 19-Jan-10 & 9-Jul-10 & 171 & 5 \\
\hline Storage & 9-Jul-10 & 4-Jan-11 & 178 & \\
\hline Recovery & 4-Jan-11 & 17-Jun-11 & 164 & 5 \\
\hline Inter-cycle & & & 24 & \\
\hline \multicolumn{5}{|l|}{ Cycle 4} \\
\hline Recharge & 11-Jul-11 & 3-Feb-12 & 217 & 5 \\
\hline Storage & 3-Feb-12 & 2-Jan-13 & 334 & \\
\hline Recovery & 2-Jan-13 & 1-Jul-13 & 181 & 5 \\
\hline
\end{tabular}




\subsubsection{Initial conditions and model calibration}

To minimize simulation time and considering symmetry of the domain, only a quarter of the region surrounding EXKR-1 is simulated. This region, shown in Figure 6.4, has the ASR well at its corner and the monitoring wells are at their respective distances along the $\mathrm{x}$-axis. The two rectangular faces intersecting the ASR well are assigned noflux boundary conditions. The other two faces are assigned specified head and concentration boundary conditions. The recharge and recovery rates used in the model are a quarter of the actual recharge and recovery rates in each cycle test.

Regional pore velocity is ignored in the simulation. Initial head before the cycle tests was approximately $48 \mathrm{ft}$ (USACE, 2012) for the entire domain assuming uniform distribution of head. The layers IAS and ICU are not expected to be impacted by ASR. These layers were only included because of their roles as conduits for recharge to and discharge from the UFA. Heads measured at MW-10 can be used to calibrate the model because the well is close to the ASR and LSM modeled heads for the UFA and FZ were very close (USACE, 2012). OKF-100U has a small open interval, which is mainly in the flow zone. Head measurements at OKF-100U may be relatively more accurate as compared to the longer interval of MW-10. Aquifer pumping tests (APT) at the monitoring wells MW-10 and OKF-100U show that the hydraulic paths to the two wells have different aquifer properties (USACE, 2012). There is a preferential flow zone as indicated by Mirecki et al. (2012) and OKF-100U intersects this zone while MW-10 doesn't. Thus under the assumption of homogeneity, mismatch of modeled and measured data for one of the wells is expected if the parameters are estimated by fitting data in the other well. 


\subsubsection{Flow calibration}

Head data were digitized from the LSM report (USACE, 2012) and then used for calibration of the PHAST model. Model calibration was achieved by using PEST to iteratively run the PHAST simulation and to update estimated parameters. During calibration, the head measurements are fitted by adjusting hydraulic conductivities (K) and specific storages (Ss) of the UFA and FZ. K and Ss may differ from that of the LSM because different model boundary conditions are used. The local scale model assumed $\mathrm{K}_{\mathrm{FZ}}=300 \mathrm{ft} / \mathrm{d}$ and estimated $\mathrm{K}_{\mathrm{UFA}}$ to be $75 \mathrm{ft} / \mathrm{d}$. This calibration values were estimated keeping in mind the value of composite K estimated for the UFA and FZ from previous APT tests $(140 \mathrm{ft} / \mathrm{d})$ where composite $\mathrm{K}$ is estimated based on equation 6.1 .

$$
K_{\text {composite }}=\frac{\sum K_{i} b_{i}}{b}
$$

where $K_{i}$ and $b_{i}$ are the hydraulic conductivity and thickness of each layer and $b$ is the total thicknesses of the aquifer.

In the PEST optimization, hydraulic head was calibrated to measurements at OKF-100U at mid-FZ. The PHAST output files file_name.head.xyz.tsv, file_name.chem.xyz.tsv, file_name.comps.xyz.tsv, and file_name.wel.xyz.tsv (Figure 6.5) are suitable for output of heads with columns of values for each node in a single row. The output to file file_name.chem.xyz.tsv can be limited to selected nodes (via PRINT_LOCATIONS data block), but the other files do not have that option. PEST requires the model output (from PHAST) and the desired PHAST-modeled observation values be read from the text output file file_name.head.txt. The output of file_name.head.txt is heads (in meters) at each node ordered by XY planes of nodes for 
each layer number and each output time selected. Selecting printing of heads to file_name.head.txt every 2 days of simulation produced a text file with 1,171,105 lines of data. PEST can search the output file for specific data according to instructions written in the instruction file. PEST is instructed to first search the desired time step, then to locate the layer of interest and within the array of data for that specified layer, it is instructed to locate the row and column numbers of the location of interest (Appendix 3).

$\mathrm{K}$ for UFA and FZ are estimated as independent parameters. The minimum, maximum and initial K values were specified based on the LSM. Additionally, storage values for the UFA and FZ were estimated independent of each other. To improve simulation, dual conductivity zones were used for FZ and UFA by dividing each of them into zones of high conductivity and low conductivity. In reactive transport simulations, mixing is controlled by dispersivity. Large dispersivity is considered a lack of knowledge about individual flow paths in the aquifer. Thus the flow zones were divided into two layers of varying conductivities to incorporate some degree of aquifer heterogeneity. Borehole geophysical flow log interpretations indicated that about 63 percent of the flow of the UFA at KRASR occurs between depths of -550 to -570 ft NGVD29 (Mirecki et al., 2012). The remaining $37 \%$ flow is in the UFA. Total of four layers represent FZ and ten layers represent UFA. The top half layers in each flow zone were assigned high conductivity and the lower ones were assigned lower conductivity. 

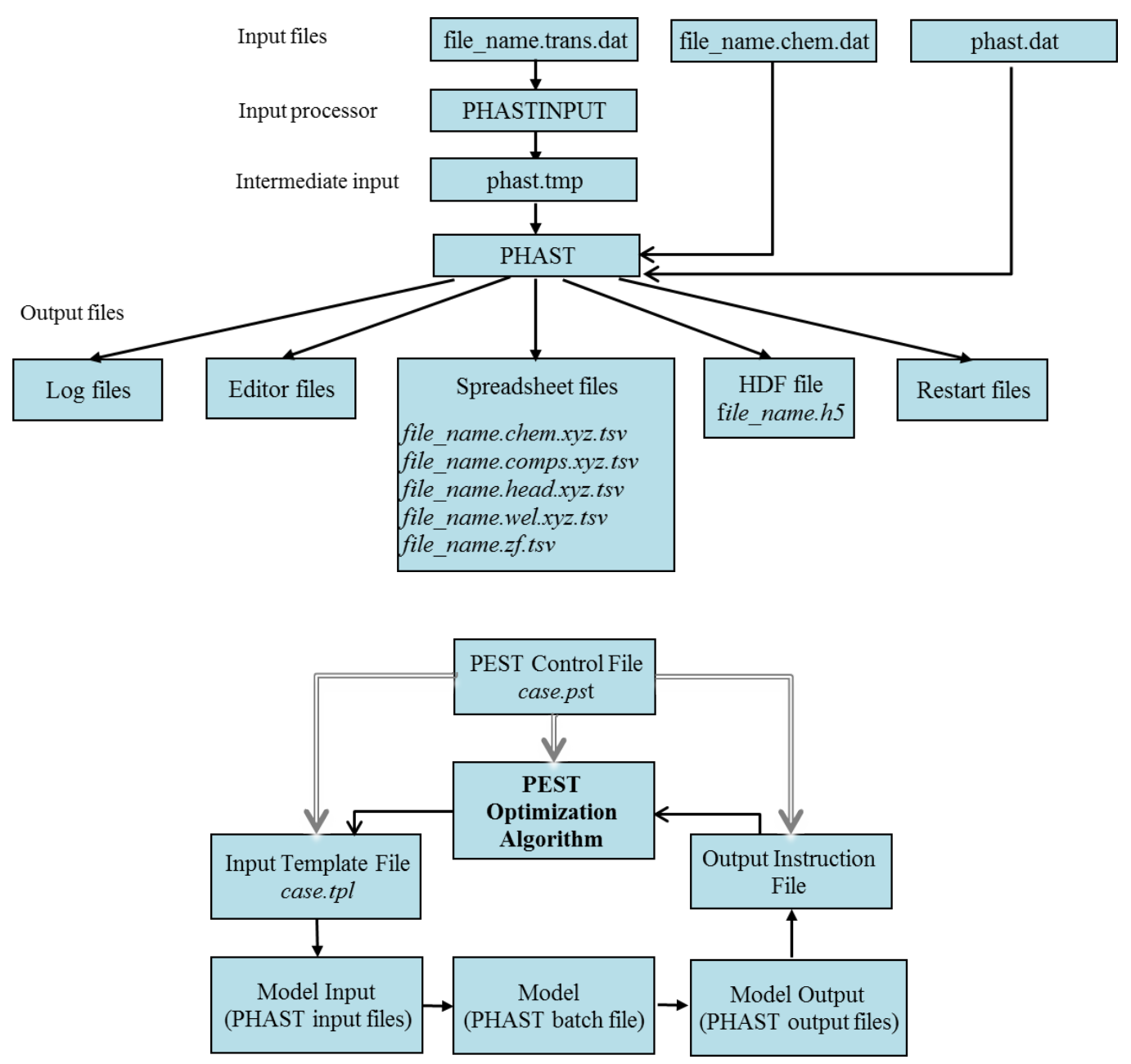

Figure 6.5 Flowcharts for a) PHAST model and b) PEST optimization processes. 

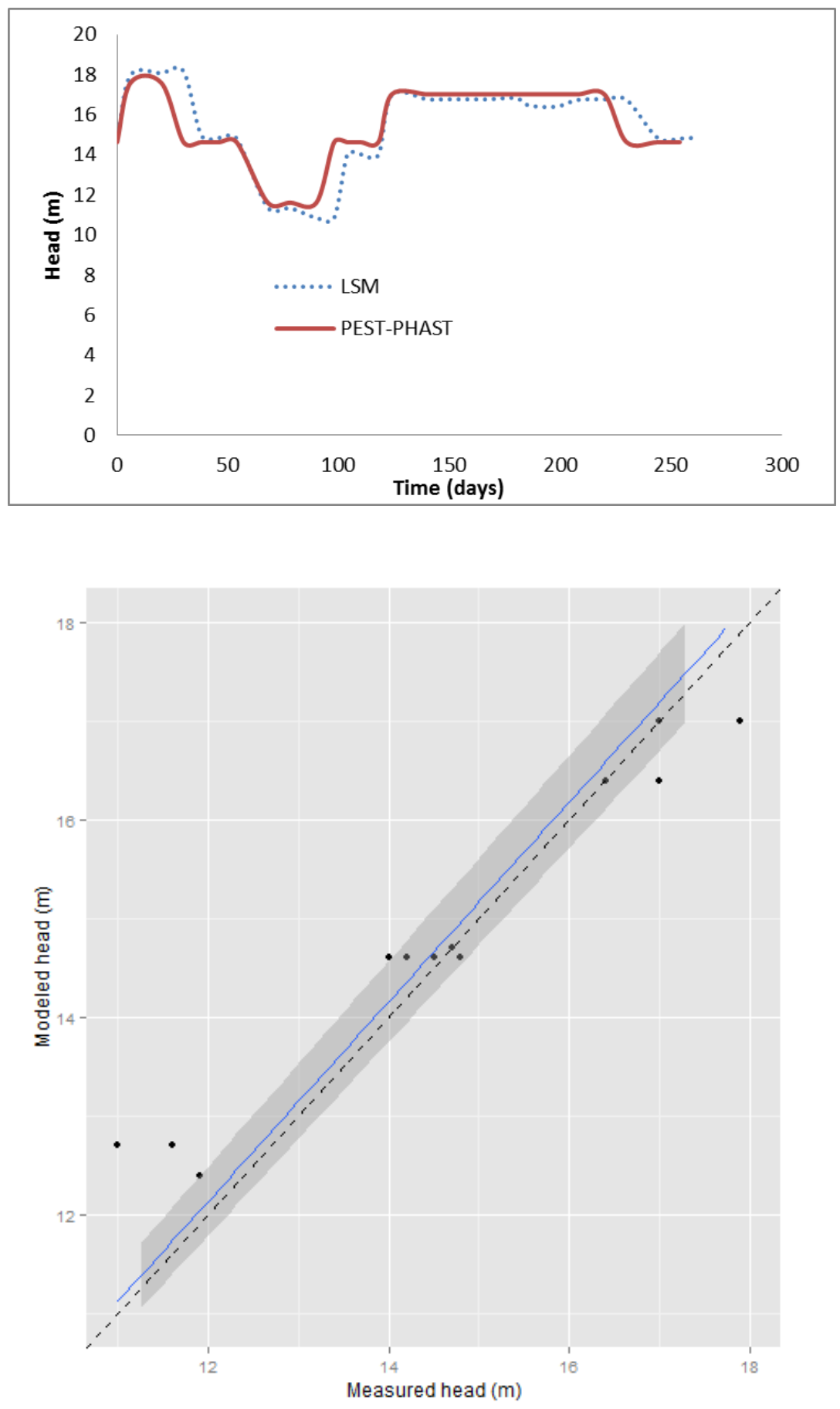

Figure 6.6 Simulated and measured heads at OKF-100U. Head versus time (top) for LSM model and the current PEST-PHAST model and comparison of measured versus PESTPHAST modeled head (bottom). The best-fit linear regression line and the 95\% confidence interval are shown. $\mathrm{R}$-square is 0.77 with respect to the 45 -degree line (dotted) 
With this approach of double conductivity for each zone, the PEST-PHAST optimization estimated the measured heads reasonably well (Figure 6.6). Adjusted flow parameters are as follows:

$\mathrm{K}_{\mathrm{FZ}}$ : High $\mathrm{K}=515.5 \mathrm{ft} / \mathrm{d}$ and low $\mathrm{K}=76.5 \mathrm{ft} / \mathrm{d}$

$\mathrm{K}_{\text {UFA }}$ : High $\mathrm{K}=123.8 \mathrm{ft} / \mathrm{d}$ and low $\mathrm{K}=25.1 \mathrm{ft} / \mathrm{d}$

These conductivities result in composite conductivities of $300 \mathrm{ft} / \mathrm{d}$ and $75 \mathrm{ft} / \mathrm{d}$ for the FZ and UFA, respectively. Overall conductivity for both FZ and UFA is $140 \mathrm{ft} / \mathrm{d}$ which is also estimated from aquifer tests (USACE, 2012). Storage for all layers was estimated at $2 \times 10^{-6}$.

\subsubsection{Transport calibration}

Initial total dissolved solids (TDS) from the flow zone are measured at around $825 \mathrm{mg} / \mathrm{L}$. Chloride in the storage zone of KRASR is relatively low but it is used for calibration because there is contrast between the injected and native $\mathrm{Cl}$ concentrations (39 $\mathrm{mg} / \mathrm{L}$ versus around $260 \mathrm{mg} / \mathrm{L}$ ). Transport parameters, such as dispersivity and porosity are estimated, by calibrating the model with $\mathrm{Cl}$ measurements in the cycle tests.

Rapid breakthrough of freshwater at MW-10 indicates that the water flows through a relatively thin flow zone (i.e., layer FZ). Cl concentration at MW-10 is approximately half the native (i.e., half of $220 \mathrm{mg} / \mathrm{L}$ ) after about 386 days at OKF-100U, which is about 14 days after beginning injection in cycle 3. Cumulative volume injected after 14 days is approximately $70 \mathrm{MG}\left(9.358 \times 10^{6} \mathrm{ft}^{3}\right)$ giving $\theta^{*} h=2.46 \mathrm{ft}$ where $\theta$ is porosity and $h$ is thickness of the flow zone. Thickness, $h$, equals $246 \mathrm{ft}$ if porosity is 0.01 . This $h$ is approximately the total thickness of FZ and UFA. Thus a rough estimation of the flow to OKF-100U would imply very low porosity of the FZ and UFA. Little is 
known about the lateral extent of the FZ and its thickness may be significantly different between MW-10 and OKF-100U.

Ionic concentrations at an observation well are written to the file file_name.well.chem.xyz, where file_name is the file name of the PHAST model. These concentrations correspond to the well datum which is the top of the uppermost intervals (Parkhurst et al., 2004). Concentration from each lower layer intersected by the well screen is weighted by flow rate contribution from each layer. Therefore concentrations at an observation well include mixing effects in the well interval and can be directly used to compare with measurements at a wellhead. Concentration data for chemical components, $\mathrm{pH}$, and alkalinity at wells are written at selected times in columnar format to the file file_name.wel.xyz.tsv. The first columns of the file are the X, Y coordinate location of the well, the well datum, simulation time, and the well number. In the current simulation, simplified boundary conditions are used which are assumed constant with time. Hydro geochemical changes in the aquifer are assumed solely due to the ASR operation. Aquifer transport parameters are estimated by calibration to $\mathrm{Cl}$ concentrations (measured at the wellhead) at observation well MW-10. Longitudinal dispersivity for FZ and UFA are estimated by linking PHAST to PEST for automatic model calibration. The PEST files (i.e., instruction file, control file and template file) are included in Appendices 1 to 5. Similarly, the input files for PHAST include file_name.trans.dat, file_name.chem.dat and wateq4f.dat) and are shown in Appendix 2 and Appendix 7.

Horizontal dispersivity to longitudinal dispersivity ratio of 1:10 is maintained for all layers throughout the optimization process. Minimum and maximum bounds of longitudinal dispersivity were 1 and $100 \mathrm{ft}$. Field-scale longitudinal dispersivities are very 
difficult to estimate for a given aquifer because there is no universal relation between longitudinal dispersivities and the scale (meters) of field observations. This is due to the highly variable nature of aquifer heterogeneity from site to site. The difficulty of drawing-out a universal relation is discussed in Gelhar et al. (1992). As a general guideline, longitudinal dispersivity can be taken as $1 / 10^{\text {th }}$ of the scale. Therefore, for OKF-100U which is at a distance of $1100 \mathrm{ft}$ from the ASR, a first estimate of long dispersivity can be up to 110ft. Gelhar et al. (1992), however, noted that the longitudinal dispersivity values can range over 2 to 3 orders of magnitude. In the current numerical calibration, dispersivity is estimated by fitting the model to observed concentrations and by adjusting dispersivity between 0 and $100 \mathrm{ft}$. Similarly effective porosities were adjusted between 0.01 and 0.3 , which are the lowest and highest porosities estimated from the LSM (USACE, 2012). 


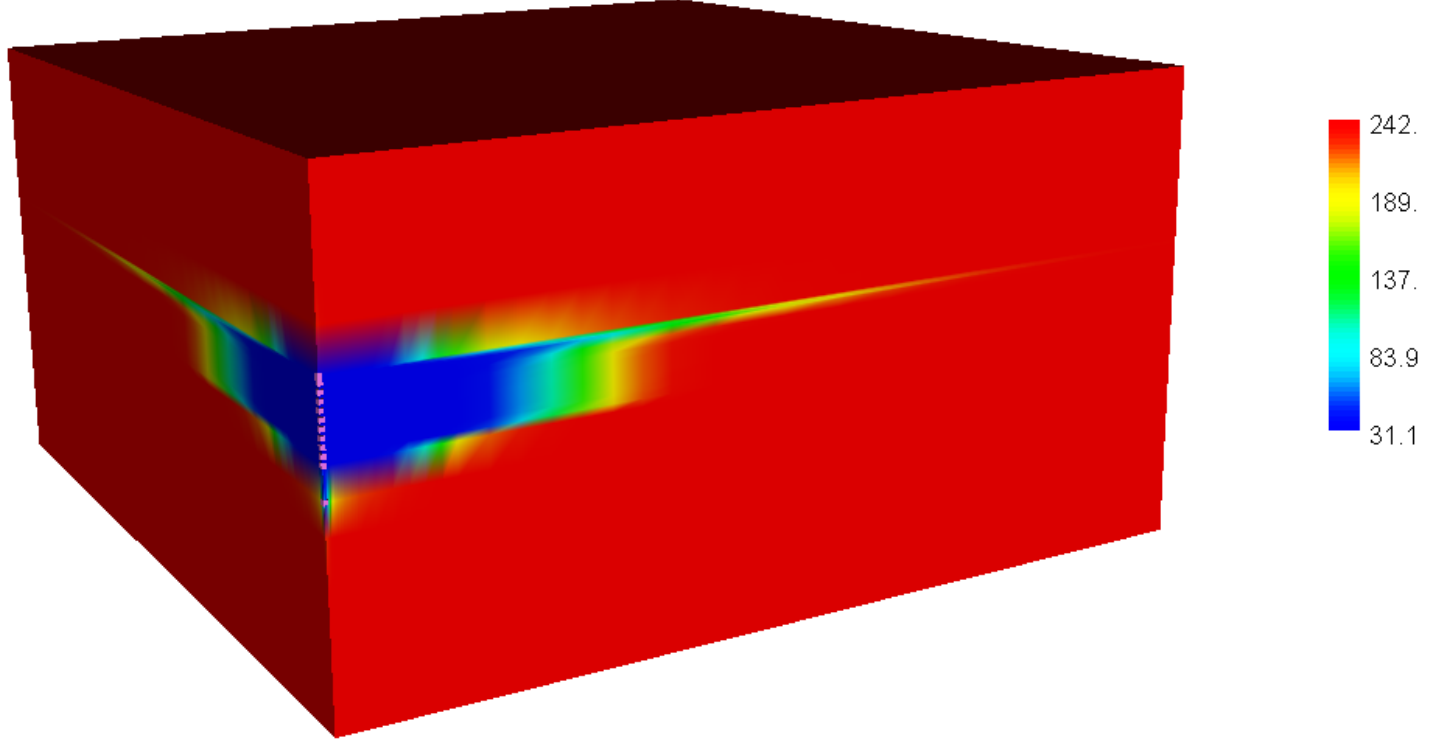

Figure 6.7 Preferential FZ and $\mathrm{Cl}$ concentration at end of cycle 1 in the model domain. Pink dots are the ASR well screen. Color bar represents chloride concentrations in mg/L. Preferential flow can be seen on the thin FZ layer. 
The simulation took 4.5 days on an Intel(R) Core(TM)2 Duo CPU @ 3.16GHz with 4.00 GB RAM. Calibrated values of longitudinal dispersivities were 1, 100, 99 and 1 $\mathrm{ft}$, respectively, for the layers of high and low conductivity in FZ and UFA (Appendix 6). Effective porosities were estimated at 0.01 for all layers of FZ and UFA. While the LSM estimated effective porosity of FZ at 0.01 , effective porosity for the UFA was much higher (i.e., 0.03) than the current result. Aquifer heterogeneity in the flow path between ASR and monitoring well complicates model representation of field conditions and simulation results may not be exact field conditions. The presence of preferential flow zones further complicates the modeling and use of a dual-porosity model may be suggested. Unfortunately, the current version of PHAST doesn't incorporate dual porosity modeling. Simulations using the adjusted porosity and dispersivity values give good agreement between measured and modeled concentrations for most of the major ions (Figure 6.8). Preferential flow and transport of $\mathrm{Cl}$ is noticeable in Figure 6.7. $\mathrm{Cl}$ is preferentially transported along the thin FZ and it is radially distributed around the ASR. The simulations in Figure 6.8 did not include mineral reactions. Therefore, transport of most of the major ions is dominated by advection processes without or negligible reactions. Of course, Ca and alkalinity are not simulated well by conservative transport for they may be affected by carbonate dissolution-precipitation reactions and possibly some cation exchange. 

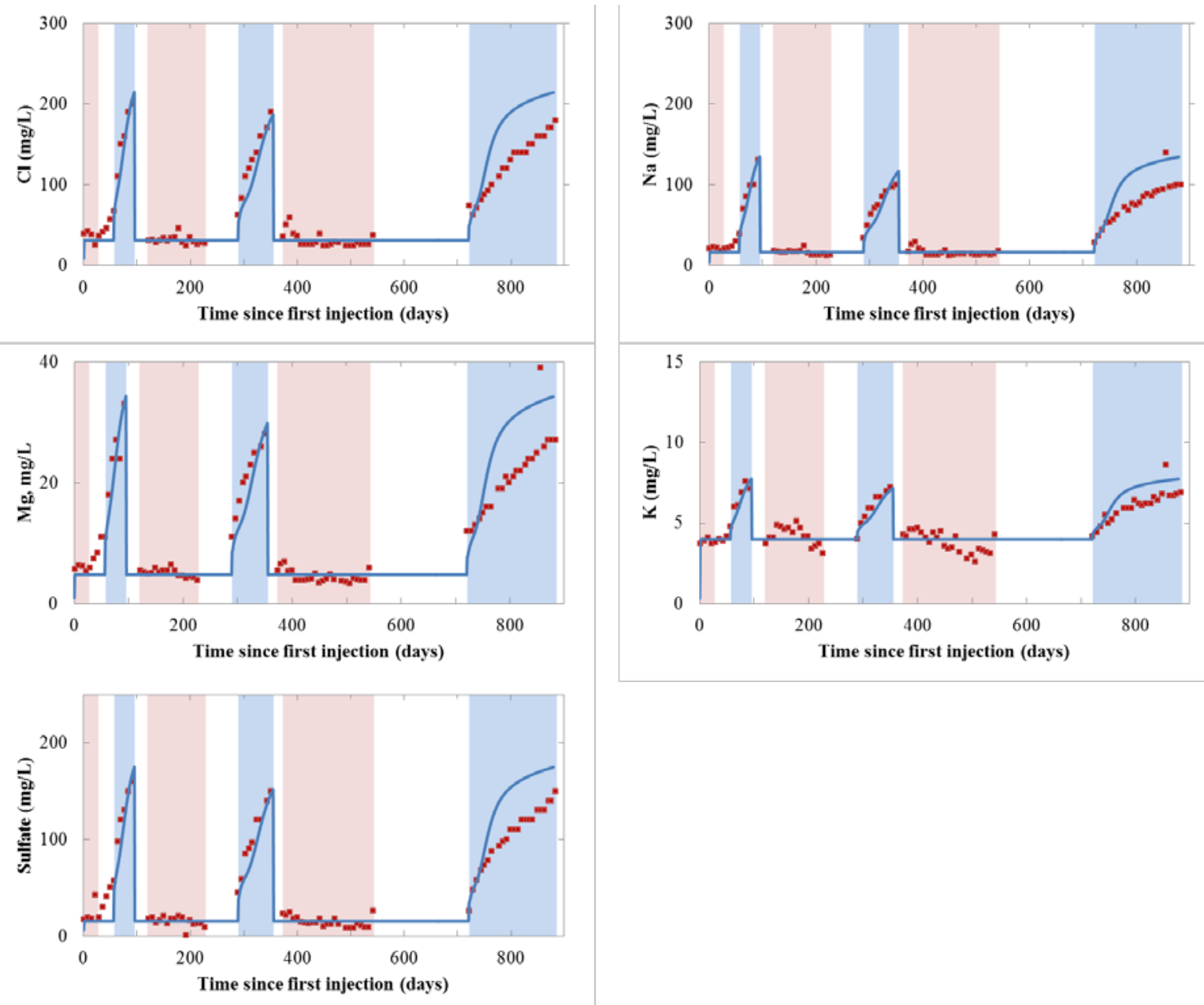

Figure 6.8 Conservative transport simulation (lines) and measured concentrations (dots) of some major ions at EXKR-1. Phases of each cycle are color coded; injection (pink), recovery (blue) and storage (white). 

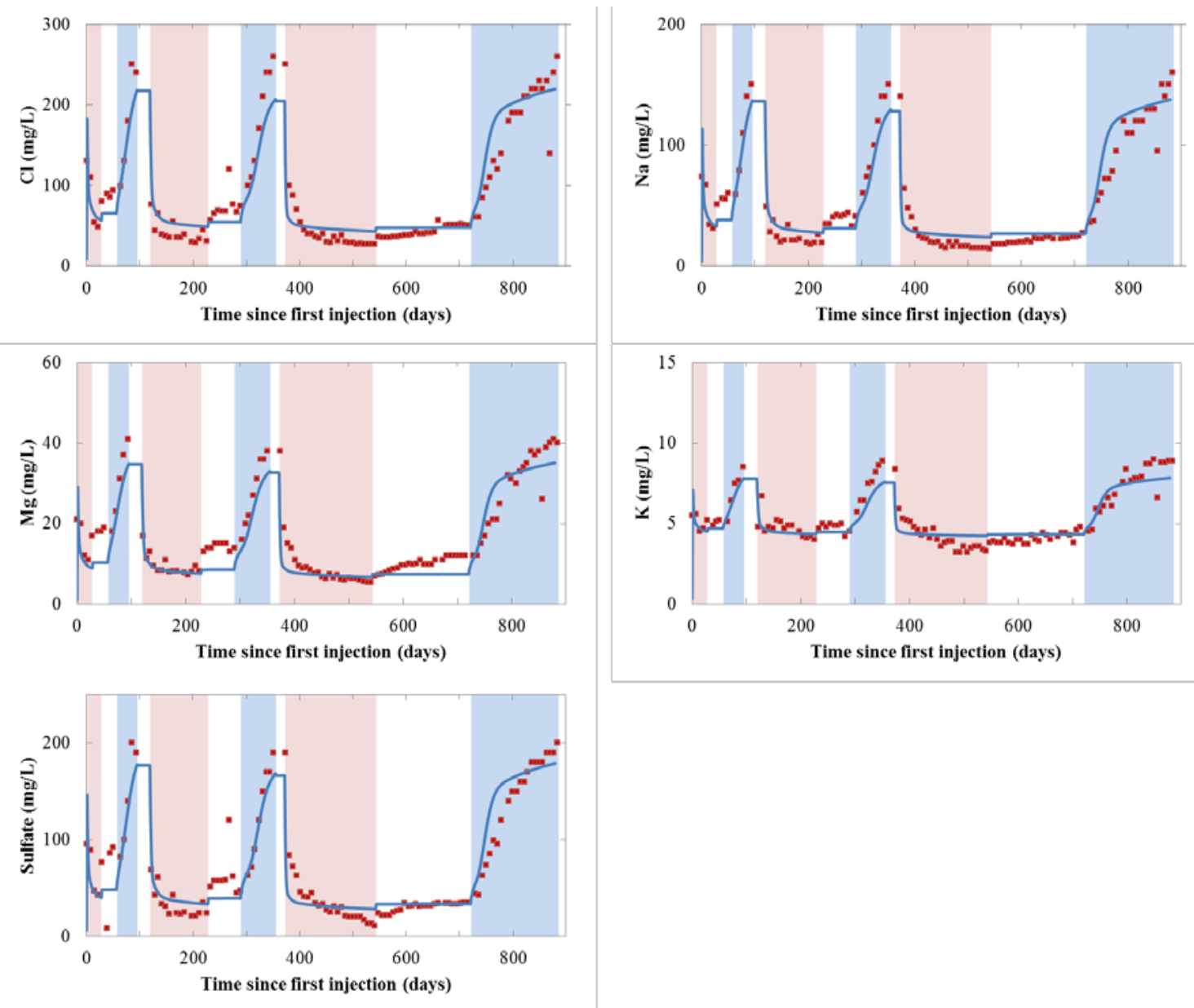

Figure 6.9 Conservative transport simulation (lines) and measured concentrations (dots) of some major ions at MW-10. Phases of each cycle are color coded; injection (pink), recovery (blue) and storage (white). 


\subsubsection{Dissolution-precipitation and ion exchange reactions at the KRASR}

Actual measured $\mathrm{Ca}$ is higher than that modeled by assuming conservative transport. This may be due to calcite dissolution and ion exchange. Inverse modeling (see section 6.4) suggested the presence of calcite dissolution-precipitation and cation exchange reactions between Ca and Na. However, cation exchange is not obvious from Figure 6.8 as $\mathrm{Na}$ appears conservative. At KRASR, calcite under-saturated recharge water mixes with calcite saturated aquifer water. Thus, it is highly likely that calcite dissolution plays a significant role in defining Ca concentration. In Figure 6.10, evolution of calcite dissolution is depicted throughout cycle 3 at KRASR. PHREEQC was used with the thermodynamic database wateq $4 f$ to calculate SI. The patterns of calcite evolution are very similar for observation wells MW-10 and OKF-100U. Calcite dissolution $(\mathrm{SI}<0)$ is observed during initial stages of recharge because the recharge water is undersaturated with calcite. Towards the end of recharge, the water equilibrates with calcite and even becomes saturated (SI $>0$ ). During storage, an episode of dissolution is observed which could be due to microbial activity because mixing of waters mainly occurs during recharge and recovery. Microbial metabolism of organic matter releases $\mathrm{CO}_{2}$, which can modify $\mathrm{pH}$, alkalinity and carbonate equilibria (see equation 1.9). Almost all recovered water samples are saturated with calcium carbonate (SI $>0$ ) because of mixing and equilibrium with calcite. 


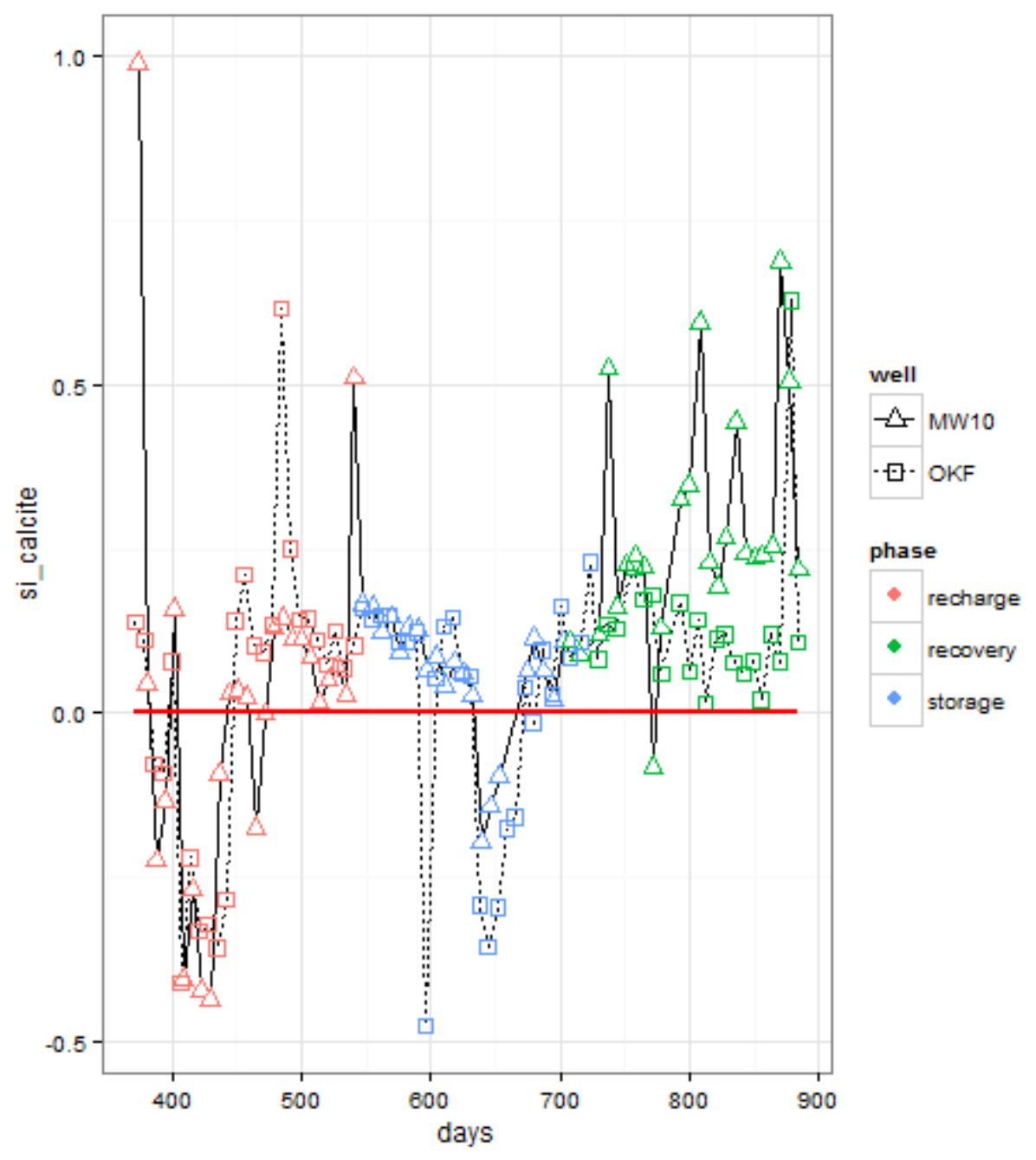

Figure 6.10 Evolution of calcite dissolution-precipitation in cycle 3 of KRASR. Calcite saturation index are calculated at monitoring wells MW-10 and OKF-100U 


\subsection{Fate of arsenic (As) at KRASR}

\subsubsection{Measurements of Fe, DO and As at KRASR}

Average As concentrations were $0.9 \mu \mathrm{g} / \mathrm{L}$ and $1.6 \mu \mathrm{g} / \mathrm{L}$, respectively, for the recharge water and the aquifer water. In the cycle tests, As is occasionally measured at concentrations greater than $1.6 \mu \mathrm{g} / \mathrm{L}$ because of its release due to geochemical reactions (Figure 6.12 and Figure 6.13). Concentration of As increases during recharge and storage phases of cycle 1 and reaches up to about $140 \mu \mathrm{g} / \mathrm{L}$ and $70 \mu \mathrm{g} / \mathrm{L}$ in OKF 100U and MW10, respectively. These maximum concentrations are observed in storage and then concentrations decrease towards background concentration during recovery phase. In cycle 2, As increases to and then decreases during recharge, remaining at very low concentrations during storage and recovery. The As peak is much lower during the second cycle because most of the As could have been mobilized from the aquifer in the previous cycle. Consequently, the As peak would be expected to decrease with subsequent cycles but instead it is seen to have increased in cycle 3 . As peaks in cycle 3 compared to cycle 2 because the higher recharge volume in cycle 3 exposed 'new' As rocks releasing it to the solution. In cycle 3, the peak is observed during storage for MW10 but during recharge for OKF 100U (Figure 6.12 and Figure 6.13). Measured As concentrations exceed the MCL of $10 \mu \mathrm{g} / \mathrm{L}$ in many of the samples from the cycle tests. But As is greatly reduced by factors of about 7 and 3.5 for OKF 100U and MW 10, respectively, in the second cycle. Thus, for the same volumes of recharge in successive cycles, As is controlled below MCL with increasing number of cycles.

Total Fe is higher in the recharge water than in the aquifer. Thus its concentration increases during recharge and decreases during recovery (Figure 6.12 and Figure 6.13). 
The measurements of $\mathrm{Fe}$ are relatively erratic. Fe concentrations generally increase during initial recovery, reach a peak, and then decrease toward the end of recovery. This is especially notable in cycle 2 of MW 10 . The patterns of increase and decrease are roughly the same for As and Fe.

DO measured at KRASR is depicted in Figure 6.11. DO breakthrough is seen in MW-10 at the end of recharge in cycle 1 (i.e., at about day 22), but it decreases with recharge in cycle 2. DO increases during initial recharge in cycle 3 but then decreases to background levels at the end of recharge phase. DO remains very low during storage and recovery in all cycles. At OKF-100U, DO remains comparatively low (below $0.3 \mathrm{mg} / \mathrm{L}$ ) and DO breakthrough has not reached this well due to its retardation by pyrite oxidation reactions. Modeling for the fate of As is therefore done on the ASR and monitoring well MW-10 only, where changes in DO, As and Fe concentrations can be used to calibrate the conceptual model of As fate and transport. 


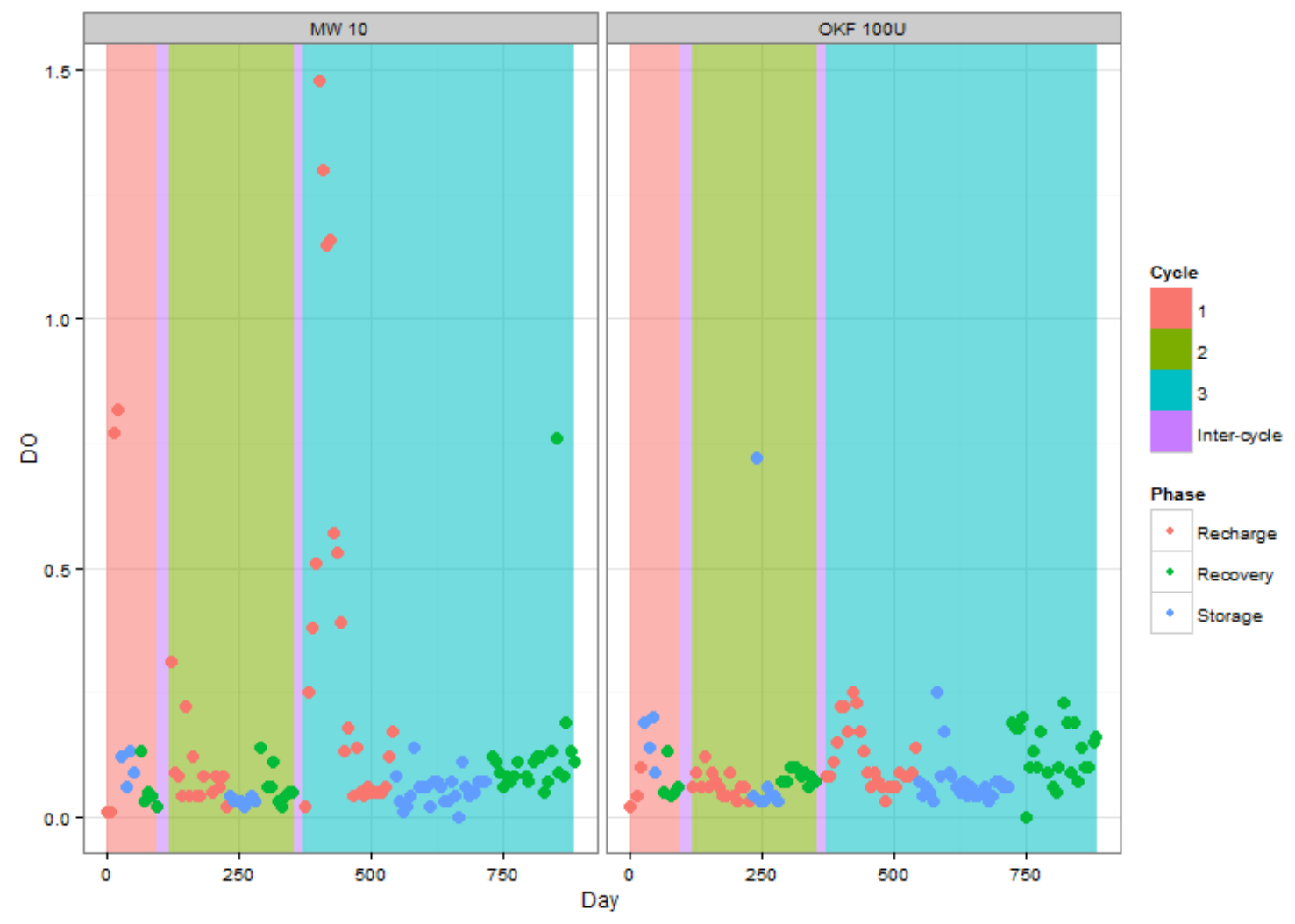

Figure 6.11 Measured DO concentrations at KRASR. Concentrations are in mg/L and are shown for cycles 1-3 at monitoring wells MW-10 (left) and OKF-100U (right) 


\subsubsection{Modeling the fate of As}

Reaction networks for the release of As are based on the following mechanism of release (Antoniou et al., 2015; Mirecki et al., 2012; Wallis et al., 2011). During injection, kinetically-controlled As-pyrite oxidation consumes DO of the injected water and mobilizes As. Simultaneously-released ferrous iron (Fe(II)) is oxidized to hydrous ferric oxides (HFO), which precipitates and forms sorption sites for As. Next, during recovery, sorbed As is remobilized either due to reductive dissolution of HFO or due to desorption resulting from competition with other ions (e.g., bicarbonate, phosphate, silica, etc.) for the limited sorption sites. Fe (II) enhances As sorption and may promote precipitation of Fe-carbonates (e.g., siderite) in native waters with high $\mathrm{HCO}_{3}$ (Antoniou et al., 2015). For reductive dissolution, possible reductants are $\mathrm{H}_{2} \mathrm{~S}$ and DOC. There are only a few DOC measurements at KRASR and the water-sediment reactions involving $\mathrm{H}_{2} \mathrm{~S}$ are hypothesized to be more influential. In line with the conceptual model of section 6.5 developed with PHAST, the following reactions are included to model the fate of As:

- Equilibrium reactions for calcite, siderite $\left(\mathrm{FeCO}_{3}\right)$, and $\mathrm{HFO}$ (i.e., $\left.\mathrm{Fe}(\mathrm{OH})_{3}\right)$; Thermodynamic data from PHREEQC's wateq4f are used. As(3) to As(5) oxidation is treated as equilibrium reaction as defined in the waterq $4 \mathrm{f}$ database.

- Kinetic oxidation of As-pyrite is defined with the formula FeAs ${ }_{0.008} \mathrm{~S}_{1.992}$ (Antoniou et al., 2015) to allow As release during pyrite oxidation. The formula gives As in pyrite of $0.5 \%$ (by weight) and is within the literature values of 0.01 to $1.12 \%$ found for South West Florida (Price and Pichler, 2006; Wallis et al., 2011). 
- Surface complexation to HFO sites; the increasing complexation capacity with increasing amounts of HFO precipitates is modeled by coupling the moles of surface sites to mass of HFO in the system (Appelo and De Vet, 2003).

At KRASR, the unknown parameters that are estimated by calibration are initial concentration of pyrite in the aquifer and sorption site density of HFO. The As content of pyrite is approximated by using the formula, $\mathrm{FeAs}_{0.008} \mathrm{~S}_{1.992}$, for As-pyrite. Pyrite concentration in the Suwannee Limestone (UFA) of central Florida ranges between 276 and 32,406 $\mathrm{mg} / \mathrm{Kg}$ (Wallis et al., 2011). Literature values for the number of sorption sites of HFO are highly variable. They range between 0.2 and $0.066 \mathrm{~mol} / \mathrm{mol}$ for the weak sites and between 0.005 and $0.00165 \mathrm{~mol} / \mathrm{mol}$ for the strong sites (Dzombak and Morel, 1990;Wallis et al., 2011). In the current model calibration, the unknown parameters are estimated by calibrating the model to observed dissolved oxygen (DO), ferrous Fe and total As.

Initial parameter values and ranges are assumed based on for KRASR. The PHREEQC database needed to be modified when calculating kinetic reactions between aqueous species (e.g., kinetic oxidation of $\mathrm{Fe}(2)$ to $\mathrm{Fe}(3)$ ). The calculations required decoupling of valence states of iron and modification of the database file. New elements Fe_di and $\mathrm{Fe} \_$tri were defined corresponding to $\mathrm{Fe}(2)$ and $\mathrm{Fe}(3)$. The master species for these elements were Fe_di+2 and Fe_tri+3 and all the reactions involving Fe in wateq4f database were modified accordingly. Iron can be oxidized by oxygen while in solution or while adsorbed on metal oxide surfaces. The reaction rates are given by Singer and Stumm (1970) and Tamura et al. (1976), respectively. Antoniou et al. (2015) suggest that Fe oxidation from metal oxide surfaces is negligible for low initial ferrihydrite 
concentration and only the Singer and Stumm (1970) rate expression is used for the KRASR model. As is retarded by adsorption to hydrous metal oxides such as HFO. Reductive dissolution of $\mathrm{HFO}$ and competition with other chemicals (such as $\mathrm{HCO}_{3}{ }^{-}$, $\mathrm{H}_{4} \mathrm{SiO}_{4}, \mathrm{Fe}^{2+}$ ) releases it to solution. The wateq $4 f$ database contains most of the surface complexation thermodynamic data required to model sorption of As and it was modified for our purpose by adding silica and carbonate sorption data on ferrihydrite (Sharif et al., 2011; Swedlund and Webster, 1999). The silica database is internally consistent with the sorption database of Dzombak and Morel (1990). The kinetic and surface complexation reactions added to the model are shown in Table 6.6. Files used in PEST-PHAST calibration are described below and can be found in Appendices 1 to 5:

1. The template file is a copy of file_name.chem.dat file of PHAST input. This is where the surface complexation, kinetics and other reactions are defined and where the estimated parameters reside.

2. While PEST can read As and Fe(II) concentrations from the PHAST output file file_name.wel.xyz.tsv, PHAST does not explicitly report DO concentrations in this file. Therefore DO is read from another PHAST output file (file_name.chem.xyz.tsv). The latter gives DO at a particular node and not the average of nodes spanning the well screen. Therefore modeled DO is fitted to DO at mid FZ which was digitized from the SEACAT profiler readings reported in Mirecki et al. (2012). Two pairs of PEST instruction and model output files were used in the PEST control file; the first instructs PEST to read As and Fe(II) from file_name.wel.xyz.tsv while the second instructs PEST to read DO from file_name.chem.xyz.tsv. The keyword PRINT_LOCATIONS was used in PHAST 
transport file to limit the output of file_name.chem.xyz.tsv to a single node representing the monitoring well, MW-10, at the sampling depth corresponding to the SEACAT sampling depth. 
Table 6.6 Kinetic reaction network included in modeling the fate of arsenic

\begin{tabular}{|c|c|c|c|}
\hline Process & Reaction equation & Constants & Reference \\
\hline Pyrite oxidation & $r_{\text {pyrite }}=k_{\text {pyr }} m_{O_{2}}^{0.5} m_{H^{+}}^{-0.11}\left(\frac{A_{p y r}}{V}\right)\left(\frac{m}{m_{o}}\right)_{p y r}^{0.67}\left(1-\Omega_{p y r}\right)$ & $\begin{array}{l}k_{p y r}=10^{-10.19} \\
\left(\mathrm{~mol} \mathrm{dm}^{-1} \mathrm{~s}^{-1}\right)\end{array}$ & $\begin{array}{l}\text { Williamson and Rimstidt } \\
\text { (1994) }\end{array}$ \\
\hline SOM oxidation & $r_{\mathrm{SOM}}=m_{\mathrm{CH}_{2} \mathrm{O}}\left(\frac{m}{m_{\mathrm{o}}}\right)_{\mathrm{CH}_{2} \mathrm{O}}\left(r_{\max \left(\mathrm{O}_{2}\right)} \frac{m_{\mathrm{O}_{2}}}{k_{\mathrm{O}_{2}}+m_{\mathrm{O}_{2}}}\right)$ & $\begin{array}{l}k_{\mathrm{O}_{2}}=2.94 \times 10^{-4} \\
\left.(\mathrm{~mol} \mathrm{~L})^{-1}\right) \\
r_{\max \left(O_{2}\right)}=1.57 \times 10^{-9} \\
\left(\mathrm{~s}^{-1}\right)\end{array}$ & $\begin{array}{l}\text { Van Cappellen and Gaillard } \\
\text { (1996) }\end{array}$ \\
\hline $\begin{array}{l}\mathrm{Fe}^{2+} \text { oxidation } \\
\text { (homogenous) }\end{array}$ & $r_{\mathrm{Fe}^{2+}}=-\left(k\left[\mathrm{OH}^{-}\right]^{2} P_{\mathrm{O}_{2}}\right) m_{\mathrm{Fe}^{2+}}$ & $\begin{array}{l}k=1.33 \times 10^{12} \\
\left(\mathrm{~L}^{2} \mathrm{~mol}^{-2} \mathrm{~atm}^{-1} \mathrm{~s}^{-1}\right)\end{array}$ & Singer and Stumm (1970) \\
\hline $\begin{array}{l}\mathrm{Fe}^{2+} \text { oxidation } \\
\text { (heterogeneous) }\end{array}$ & $r_{\mathrm{Fe}_{a d s}^{2+}}=-k \times m_{\mathrm{Fe}_{a d s}^{2+}} \times P_{\mathrm{O}_{2}}$ & $\begin{array}{l}k=73 \\
\left(\mathrm{~mol} \mathrm{~L}^{-1} \mathrm{~s}^{-1}\right)\end{array}$ & Tamura et al. (1976) \\
\hline
\end{tabular}



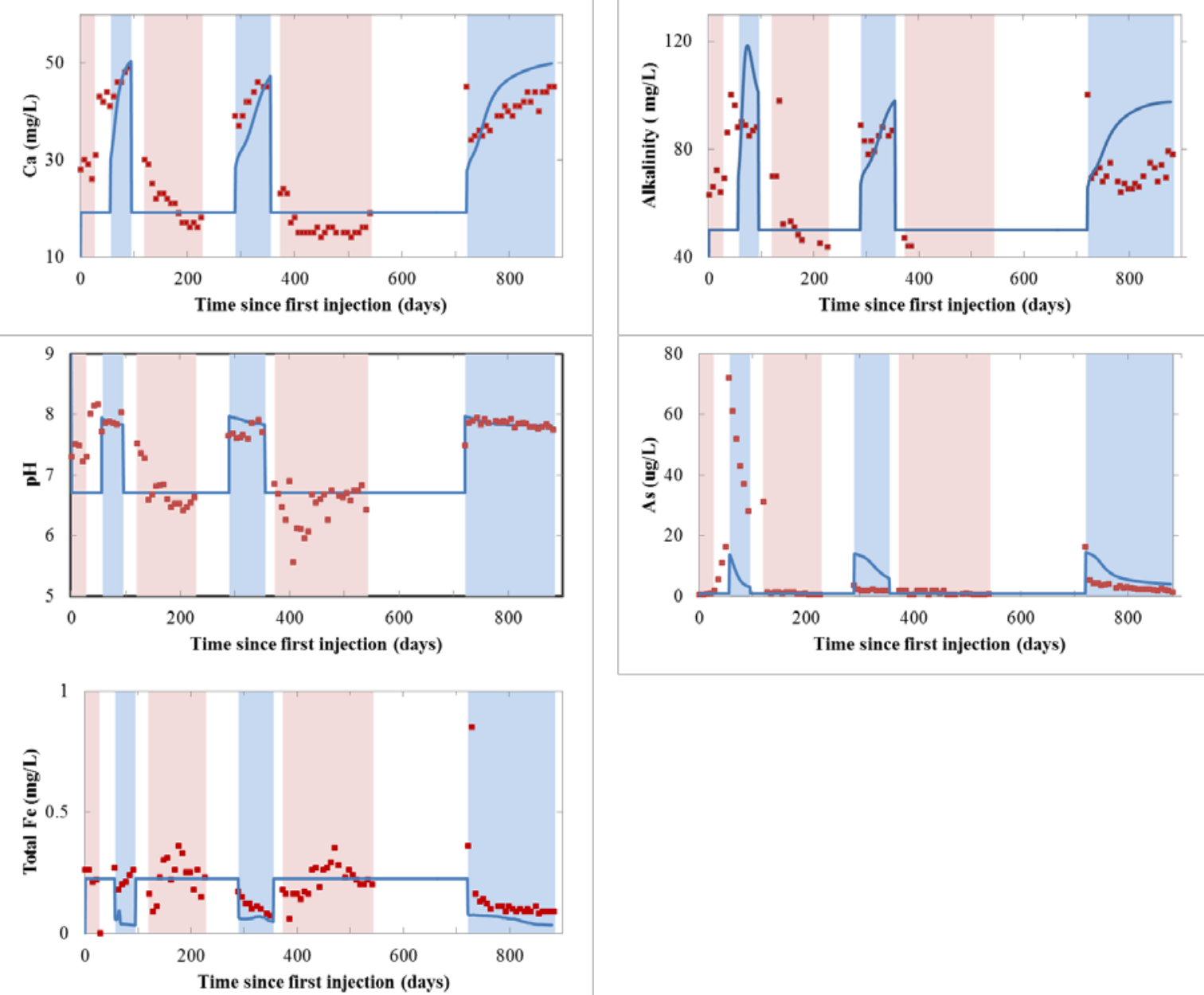

Figure 6.12 Reactive transport simulation (lines) and measured concentrations (dots) of reactive constituents and trace metals at EXKR-1. Phases of each cycle are color coded; injection (pink), recovery (blue) and storage (white). 

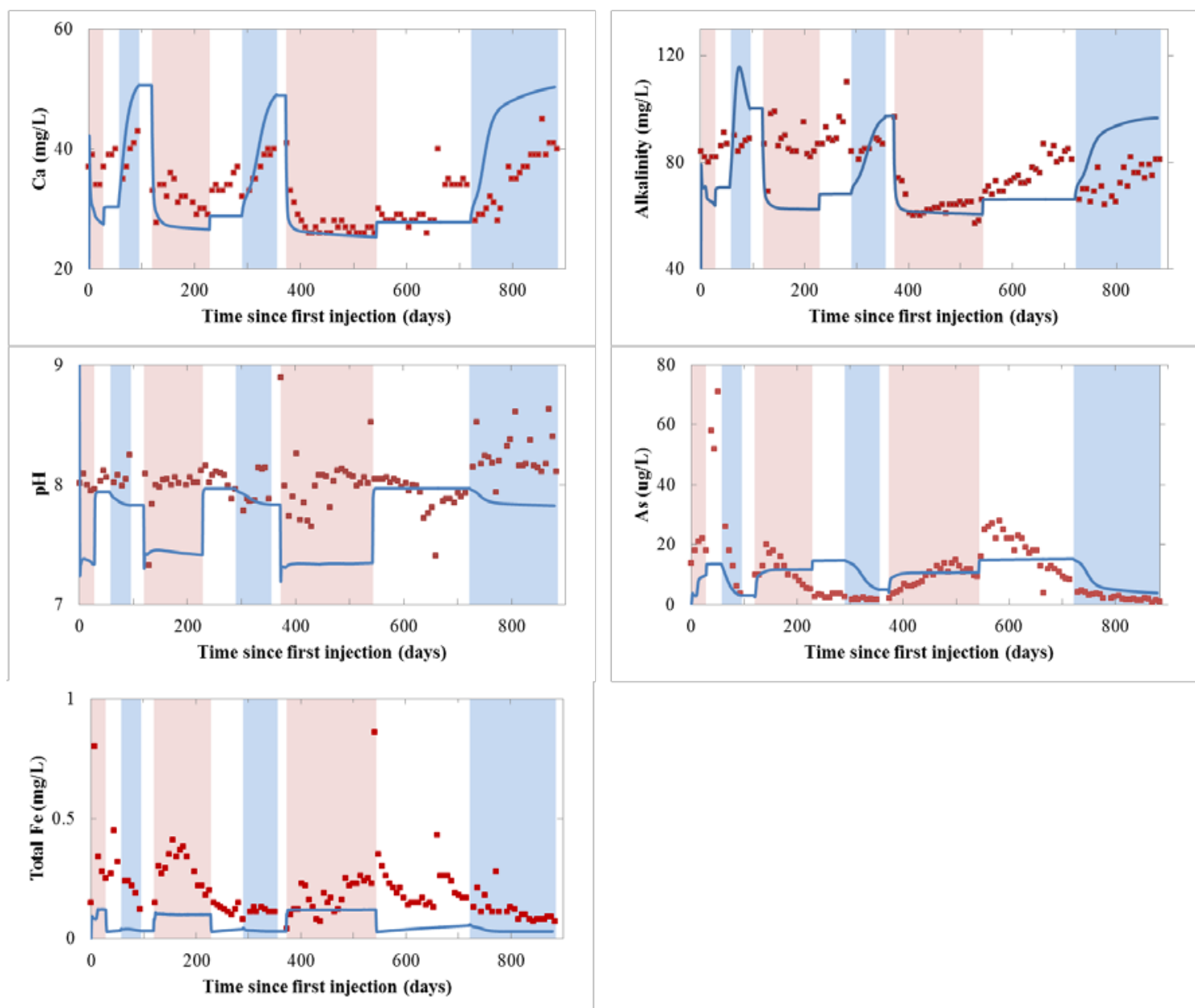

Figure 6.13 Reactive transport simulation (lines) and measured concentrations (dots) of reactive constituents and trace metals at MW-10. Phases of each cycle are color coded; injection (pink), recovery (blue) and storage (white). 
Results of calibration are shown in the PEST output file (Appendix 6). The estimated parameters were used to run a reactive transport simulation for the first three cycle tests. Figure 6.12 and Figure 6.13 compare measured and modeled concentration of reactive constituents at the KRASR site. The model compares well to measured concentrations of Ca, alkalinity, $\mathrm{pH}$ and total Fe at EXKR-1 while As is under-predicted in the first cycle. Ca and alkalinity are also well-predicted at MW-10 (Figure 6.13), which may imply that the assumption of calcite equilibrium works well. Lower $\mathrm{pH}$ is modeled at MW-10 especially during injection phases. This is due to low $\mathrm{pH}$ of the recharge water and the model does not appear to capture significant reactions altering $\mathrm{pH}$ of the water. The reactions may have not occurred due to high velocity of flow (due to the very low estimated effective porosity) giving rise to shorter time for water-rock interaction. Similar under-prediction of Fe and As is also seen in Figure 6.13. Reaction networks involving the release of As and Fe are very complex and they are not well understood. With the network of reactions considered in this modeling, the trends of As and Fe concentrations during cycle tests are sufficiently predicted. The concentrations predicted, however, are less than measured concentrations. Again, inclusion of a dual-porosity medium where there are mobile and immobile phases may give better results.

\subsection{Concluding remarks}

The UFA is a relatively fresh aquifer at the KRASR site with chloride concentrations less than the standard of $250 \mathrm{mg} / \mathrm{L}$ for drinking purposes. A reactive transport model was setup and calibrated to measured constituent concentrations during cycle tests at the site. Major ions, such as $\mathrm{Cl}, \mathrm{Na}, \mathrm{K}, \mathrm{Mg}$ and sulfate were effectively modeled by the conservative transport model, without including water-rock reactions in the aquifer. 
Inclusion of calcite dissolution-precipitation by assuming equilibrium reactions was necessary to reasonably model Ca and alkalinity concentrations in the ASR and nearby monitoring well. A more complex network of kinetic and surface complexation reactions was incorporated to model the fate of trace metals (i.e., Fe, and As). The trends of trace metal concentrations during various phases of the cycle tests were closely estimated by the model. Generally, the model showed excellent match with respect to most of the constituents measured at the ASR well. This could be due to the dominance of mixing and transport near the well vicinity, which the model appears to capture well. However, $\mathrm{pH}$ and trace metal concentrations were lower than measured values at the nearest monitoring well. The low values corresponded to low concentrations in the recharge water and mainly occurred during the recharge phase of each cycle. Besides the complex interactions of chemical processes affecting fate of trace metals, the low concentrations modeled may be due to an estimated low effective porosity by the model. A dualporosity model including mobile and immobile phases of the aquifer may be needed to describe the fate of trace metals at KRASR more accurately.

A combination of PEST and PHAST was found to be a powerful modeling tool to evaluate and predict water quality changes at different stages of an ASR cycle. Results of this analysis can be used to predict water quality at KRASR with respect to major ions in future cycle tests or operational stages. Modeling capability of trace metals (i.e., Fe and As) can be improved with detailed hydrogeochemical characterization in the field, such as the range of quantities of minerals present in the aquifer (e.g., pyrite, ferric oxides, etc.). 


\section{References}

Antoniou, E., van Breukelen, B. and Stuyfzand, P. (2015). Optimizing aquifer storage and recovery performance through reactive transport modeling. Appl. Geochem., 61; 29-40.

Antoniou, E.A., Stuyfzand, P.J. and van Breukelen, B.M. (2013). Reactive transport modeling of an aquifer storage and recovery (ASR) pilot to assess long-term water quality improvements and potential solutions. Appl. Geochem., 35; 173-186.

Appelo, C. and De Vet, W. (2003). Modeling in situ iron removal from groundwater with trace elements such as As. In Arsenic in Ground Water. : Springer, pp. 381.

Doherty, J., Brebber, L. and Whyte, P. (2010). PEST: Model-Independent Parameter Estimation - User Manual. Brisbane, Australia: Watermark Numerical Computing.

Dzombak, D. and Morel, F. (1990). Surface complexation modeling: Hydrous ferric oxide. John Wiley \& Sons.

Gelhar, L.W., Welty, C. and Rehfeldt, K.R. (1992). A critical review of data on field scale dispersion in aquifers. Water Resour. Res., 28(7); 1955-1974.

Greskowiak, J. (2006). Reactive transport processes in artificially recharged aquifersField and modelling studies. HU Berlin.

Guo, W. and Langevin, C. (2002). User's guide to SEAWAT. US Geological Survey Tech Water Resour Invest, book 6.

Harbaugh, A.W., Banta, E.R., Hill, M.C. and McDonald, M.G. (2000). MODFLOW2000, the US Geological Survey Modular Ground-Water Model: User Guide to Modularization Concepts and the Ground-Water Flow Process. : US Geological Survey, Reston.

Merritt, M.L. (1997). Tests of subsurface storage of freshwater at Hialeah, Dade County, Florida, and numerical simulation of the salinity of recovered water. No. 2431. USGPO; Denver, CO: US Geological Survey, Branch of Information Services.

Mirecki, J.E. (2004). Water-Quality Changes During Cycle Tests at Aquifer Storage Recovery (ASR) Systems of South Florida. U. S. Army Engineer Research and Development Center ERDC/ELTR-04-8.

Mirecki, J.E., Bennett, M.W. and López Baláez, M.C. (2012). Arsenic Control During Aquifer Storage Recovery Cycle Tests in the Floridan Aquifer. Ground Water, 51(4); 539-549. 
Misut, P.E. and Voss, C.I. (2007). Freshwater-saltwater transition zone movement during aquifer storage and recovery cycles in Brooklyn and Queens, New York City, USA. Journal of hydrology, 337(1); 87-103.

Parkhurst, D.L. and Appelo, C. (2013). Description of input and examples for PHREEQC version 3: a computer program for speciation, batch-reaction, one-dimensional transport, and inverse geochemical calculations. US Geol. Surv. Techniques and Methods, book 6, chap. A-43.

Parkhurst, D.L., Kipp, K.L., Engesgaard, P. and Charlton, S.R. (2004). PHAST--A Program for Simulating Ground-Water Flow, Solute Transport, and Multicomponent Geochemical Reactions. : US Department of the Interior, US Geological Survey.

Petkewich, M.D., Parkhurst, D.L., Conlon, K.J., Campbell, B.G. and Mirecki, J.E. (2004). Hydrologic and Geochemical Evaluation of Aquifer Storage Recovery in the Santee Limestone/Black Mingo Aquifer, Charleston, South Carolina, 1998-2002. : US Department of the Interior, US Geological Survey.

Poeter, E.P. and Hill, M.C. (1998). Documentation of UCODE, a Computer Code for Universal Inverse Modeling. : DIANE Publishing.

Price, R.E. and Pichler, T. (2006). Abundance and mineralogical association of arsenic in the Suwannee Limestone (Florida): Implications for arsenic release during waterrock interaction. Chem. Geol., 228(1); 44-56.

Prommer, H., Barry, D. and Zheng, C. (2003). MODFLOW/MT3DMS Based Reactive Multicomponent Transport Modeling. Ground Water, 41(2); 247-257.

Reese, R.S. (2002). Inventory and Review of Aquifer Storage and Recovery in Southern Florida. US Department of the Interior, US Geological Survey 2002-4036.

Reese, R.S. and Alvarez-Zarikian, C.A. (2007). Hydrogeology and aquifer storage and recovery performance in the Upper Floridan Aquifer, Southern Florida. Scientific Investigations Report 2006-5239.

Sharif, M.S.U., Davis, R.K., Steele, K.F., Kim, B., Hays, P.D., Kresse, T.M. and Fazio, J.A. (2011). Surface complexation modeling for predicting solid phase arsenic concentrations in the sediments of the Mississippi River Valley alluvial aquifer, Arkansas, USA. Appl. Geochem., 26(4); 496-504.

Singer, P.C. and Stumm, W. (1970). Acidic mine drainage: the rate-determining step. Science 167 (3921); pp. 1121.

Swedlund, P.J. and Webster, J.G. (1999). Adsorption and polymerisation of silicic acid on ferrihydrite, and its effect on arsenic adsorption. Water Res., 33(16); 3413-3422. 
Tamura, H., Goto, K. and Nagayama, M. (1976). The effect of ferric hydroxide on the oxygenation of ferrous ions in neutral solutions. Corros. Sci., 16(4); 197-207.

USACE (2012). Draft local scale model report. Report prepared for U.S. Army Corps of Engineers Jacksonville District, dated December 2012, 85p. Available at http://141.232.10.32/pm/projects/project_docs/pdp_32_lake_o_asr_pilot/Appendi x\%20A_LocalScaleModelingReport.pdf.

Van Cappellen, P. and Gaillard, J. (1996). Biogeochemical dynamics in aquatic sediments. Reviews in mineralogy and geochemistry, 34(1); 335-376.

Voss, C. and Provost, A. (2010). SUTRA-a model for saturated-unsaturated, variabledensity ground-water flow with solute or energy transport. U. S. Geological Survey Water-Resources Investigations Report 02-4231.

Wallis, I., Prommer, H., Pichler, T., Post, V., B. Norton, S., Annable, M.D. and Simmons, C.T. (2011). Process-based reactive transport model to quantify arsenic mobility during aquifer storage and recovery of potable water. Environ. Sci. Technol., 45(16); 6924-6931.

Ward, J.D., Simmons, C.T. and Dillon, P.J. (2008). Variable-density modelling of multiple-cycle aquifer storage and recovery (ASR): importance of anisotropy and layered heterogeneity in brackish aquifers. Journal of hydrology, 356(1); 93-105.

Williamson, M.A. and Rimstidt, J.D. (1994). The kinetics and electrochemical ratedetermining step of aqueous pyrite oxidation. Geochim. Cosmochim. Acta, 58(24); 5443-5454.

Zheng, C. and Wang, P.P. (1999). MT3DMS: A modular three-dimensional multispecies transport model for simulation of advection, dispersion, and chemical reactions of contaminants in groundwater systems; documentation and user's guide, Alabama University. 


\section{MULTI-OBJECTIVE OPTIMIZATION OF WATER SUPPLY MANAGEMENT AND AUGMENTATION IN THE BISCAYNE AQUIFER}

\subsection{Abstract}

A management strategy is implemented to control saltwater intrusion in the Biscayne Aquifer. The management uses an abstraction and a recharge well. In this method, saline water is abstracted and desalinated; part of the desalinated water is used for municipal purposes while the remaining is used to recharge the aquifer. A linked multi-objective simulation-optimization management model was used to optimize the management process by minimizing economic and environmental costs for a case of the Biscayne Aquifer. The optimization process seeks for the most effective combination of well locations, well depths, and recharge and abstraction rates. SEAWAT was used to simulate solute transport and NSGA-II was used for multi-objective optimization. Management scenarios employed desalinated water for recharge. A set of optimum solutions (i.e. a Pareto front) was generated for each management scenario and for varying quantities of surface recharge. Optimization results show that the management methods are effective in pushing back the saltwater front as far as $3000 \mathrm{~m}$ towards the ocean. The Pareto of optimum solutions should provide a decision-support tool for decision makers in SWI management of the Biscayne Aquifer.

\subsection{Simulation-optimization of groundwater management}

Groundwater management is of crucial importance in coastal aquifers. Water demand in such aquifers is usually very high because of urbanization along the coast. However, over-pumping can result in progressive saltwater intrusion, which may lead to abandonment of intruded water supply wells. The primary management objective is 
maximization of pumped water while minimizing saltwater intrusion. There is no single solution to such conflicting objectives; instead a set of "non-dominated" solutions with some tradeoff between the objectives are desired.

An example of a multi-objective optimization is given in Table 7.1, where nine flight tickets with different prices and travel times are shown. It is desired to select the best tickets that cost less and take shorter travel time. This is a multi-objective problem aiming at minimizing both ticket price and travel time. Ticket B costs higher but takes shorter time than ticket A. Both tickets are kept in the set of solutions because one does not dominate the other. On the other hand, ticket $\mathrm{C}$ is clearly dominated by B because it costs higher and takes longer time. Ticket $\mathrm{C}$ is, therefore, eliminated from the solution. Tickets D, F, H are dominated by B, E and G, respectively. Tickets A, B, E, G and I are, therefore, the "non-dominated" optimum solutions and represent the Pareto front (Figure 7.1). With the Pareto front, a decision maker can trade-off between the two objectives; ticket A may be chosen if least price is desired (but with the burden of longer travel time), ticket E may be chosen if a moderate price and travel time are desired.

Table 7.1 Multi-objective optimization: airplane flight time and ticket price

\begin{tabular}{ccc} 
Ticket & $\begin{array}{c}\text { Ticket Price } \\
\text { (dollars) }\end{array}$ & $\begin{array}{c}\text { Travel Time } \\
\text { (hours) }\end{array}$ \\
\hline A & 1600 & 10 \\
B & 1650 & 8.5 \\
C & 1700 & 9 \\
D & 1750 & 9.5 \\
E & 1800 & 7.5 \\
F & 2100 & 8 \\
G & 2200 & 6 \\
H & 2300 & 6.5 \\
I & 2400 & 5.5
\end{tabular}




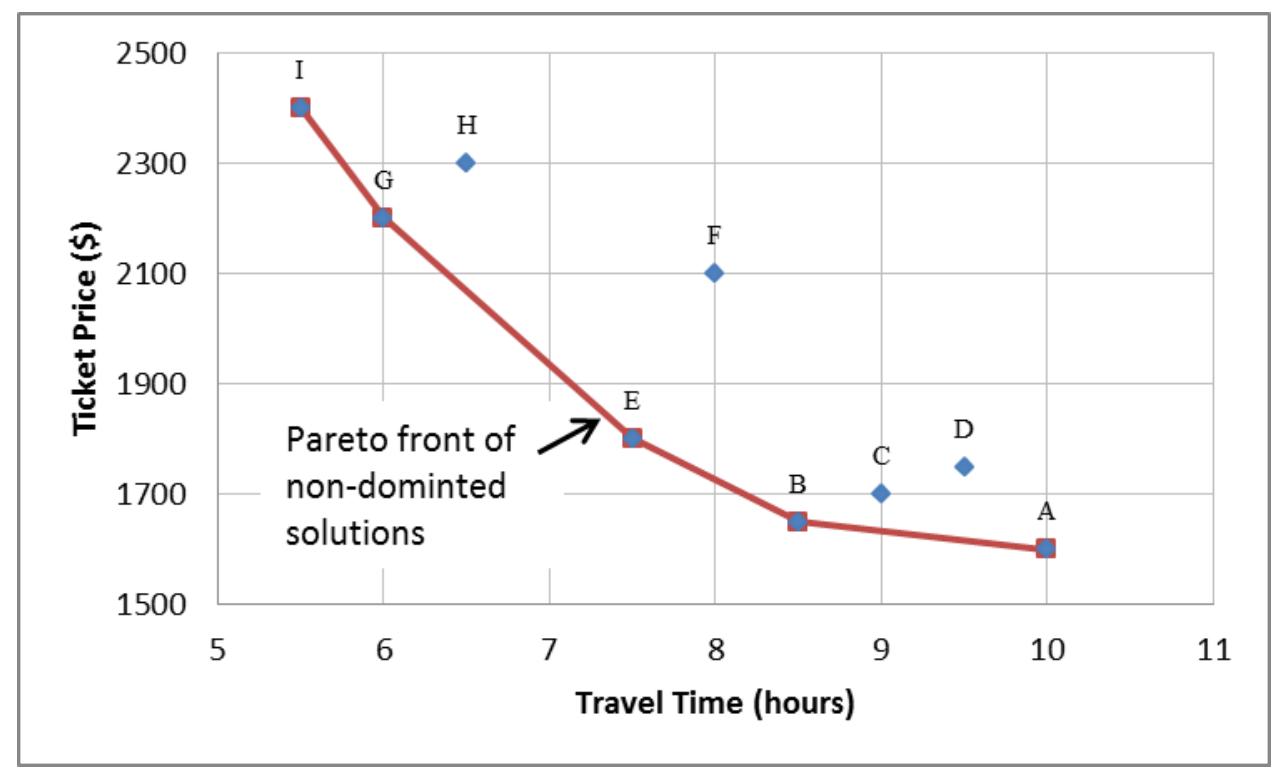

Figure 7.1 A Pareto front of the flight example

Decision models combining simulation-optimization framework are indispensable for the optimal management of coastal groundwater. Use of optimization methods in coastal aquifers have recently been reviewed by Ketabchi and Ataie-Ashtiani (2015b), Singh (2014, 2015), Sreekanth and Datta (2015) and Werner et al. (2013).Various programming techniques including linear and non-linear programming, genetic algorithms (GA), artificial neural networks (ANN) and multi-objective optimization models have been described in Singh (2014; 2015). Ketabchi and Ataie-Ashtiani (2015b) recently provided a more up-to-date review of efficient optimization algorithms and the use of surrogate models in combined simulation-optimization techniques. The approach of combined simulation-optimization has been gaining popularity in the field of coastal groundwater management. In this approach, a simulation tool is combined with an optimization tool to successively assess objective functions (via optimization) and to 
update state variables (through simulation). Analytical solutions, numerical models and surrogate models are used as simulators while evolutionary algorithms (EA) such as GA are becoming popular optimization tools (Ketabchi and Ataie-Ashtiani, 2015b). Examples of references using the various simulation and optimization methods can be found in Ketabchi and Ataie-Ashtiani (2015b) and Sreekanth and Datta (2015).

Of the various EAs (such as evolution strategies, GA, simulated annealing, particle swarm optimization, harmony search, artificial bee colony, etc.), GAs are the most popular. The concept of GA was first developed by Holland and his colleagues in the 1960s and 1970s (Holland, 1975; Konak et al., 2006). Applications of GAs in simulation-optimization of groundwater management can be found in a number of recent publications (Abd-Elhamid and Javadi, 2011; Javadi et al., 2015; Ketabchi and AtaieAshtiani, 2015a; Ketabchi and Ataie-Ashtiani, 2015b; Park, 2004; Qahman et al., 2005; Qahman et al., 2009; Sreekanth and Datta, 2011a). Most of the studies were applied to hypothetical cases and had single objectives, such as optimizing pumping rate or pumping locations or operating costs. Most management problems, however, are multi objective in nature. In multi-objective optimization, trade-off between various objectives is reflected in Pareto-optimal solutions where no improvement in any objective is possible without sacrificing the other objective functions (Konak et al., 2006).

Fast non-dominated sorting genetic algorithm (NSGA-II) developed by Deb et al. (2002) is one of the most widely used multi-objective genetic algorithms. A combination of NSGA-II and numerical simulation methods have been used in hypothetical aquifers (Bhattacharjya and Datta, 2009; Dhar and Datta, 2009; Javadi et al., 2015; Kourakos and Mantoglou, 2011; Sreekanth and Datta, 2010; Sreekanth and Datta, 2011b) and in real 
cases (Kourakos and Mantoglou, 2013; Sreekanth and Datta, 2014). Dhar and Datta (2009) modified NSGA-II by including Latin hypercube sampling strategy so that samples were uniformly distributed over the bounding space. Kourakos and Mantoglou (2011; 2013) and Dhar and Datta (2009) used variable density models in their simulation. Generally, use of variable density models as opposed to sharp-interface approximations, required long computer run times ranging from several hours up to 30 days (Sreekanth and Datta, 2015). Surrogate models such as ANN could be used in simulationoptimization methods to reduce computational burden (Dhar and Datta, 2009; Sreekanth and Datta, 2010).

\subsection{Description of the management method}

A combination of abstraction and recharge wells is used to test the control of saltwater intrusion in the Biscayne Aquifer. In the ADR method, brackish water is abstracted from the salt water intrusion zone and it is desalinated to meet water demand as well as to artificially recharge the aquifer (Abd-Elhamid and Javadi, 2011). The management method thus involves a pumping well and a recharge well suitably located for cost-effective management of SWI. In this chapter, a linked simulation-optimization technique is used to apply the method to a section of the Biscayne Aquifer with the intent of providing a decision support system for cost-effective management of SWI. The simulation-optimization technique aims to simultaneously minimize total amount of salt in the aquifer and total economic cost of the management. Iterative simulationoptimization ultimately results in a set of optimum solutions comprising optimal depths, locations and abstraction/recharge rates of wells in each management scenario. Each solution has a total cost and total salt concentration associated with it. The Pareto front is 
the set of solutions plotted against the objective functions (i.e. total cost and total salt in the aquifer).

\subsection{Simulation-optimization method used}

SEAWAT is used to simulate the physical system and NSGA-II is used for optimization. The flowchart in Figure 7.2 shows the steps in the linked simulationoptimization method. A random initial population is first generated based on the ranges of possible values for well depths, locations and flow rates. NSGA-II repeatedly calls SEAWAT to compute the state variables (e.g., heads, concentrations) corresponding to each set of generated design variables. Next, NSGA-II computes the objective functions and evaluates their fitness. The decision variables are then updated using the evolutionary processes of selection, cross-over and mutation on the pool of parent generations. Best solutions from the pool of parents and offspring populations are thus selected. The new values of decision variables are returned to SEAWAT and the state variables are computed. The process is repeated until the desired number of generations or convergence criteria are met.

This simulation-optimization method is implemented in a Python framework to allow easier communication between SEAWAT and NSGA-II. To run SEAWAT, a python script of commands that employed FloPy (Baker et al., 2015) modules was used. NSGA-II was implemented in Python using DEAP. FloPy is available on the GitHub repository at https://github.com/modflowpy/flopy and DEAP is available on the same repository at https://github.com/DEAP/deap. 


\subsubsection{Use of FloPy for simulation}

FloPy is a collection of Python scripts for building, running, and processing MODFLOW, MODPATH, MT3D, SWI, and SEAWAT models. The FloPy project is undergoing continuous development and the development branch of this project had been installed from GitHub repository. FloPy version 3.2.2 is used. Model packages are included for MODFLOW, MODPATH, MT3DMS and SEAWAT. Additionally, utility tools such as binary file readers (i.e., to read binary concentration output form MT3DMS) are included. A number of modules defined for each class can be called to perform desired operations. For MODFLOW, for example, $m f b a s, m f c h d, m f w e l$ modules contain MODFLOW's Basic Package class, Constant Head Package class and Well Package class, respectively. After importing FloPy into Python, a well object can be added with mfwel. Appendix 8 summarizes FloPy's modules and packages. Available methods associated with each module class can be found in the user documentation of FloPy.

\subsubsection{Use of DEAP for optimization}

DEAP is an evolutionary computation framework in Python. The source codes have been released in Python's PyPI and its source codes and tutorials are available in GitHub. DEAP's functionality includes, but is not limited to:

- Genetic algorithm

- Genetic programing

- Evolution strategies

- Multi-objective optimization (NSGA-II, SPEA2, MO-CMA-ES)

- Co-evolution (cooperative and competitive) of multiple populations

- Hall of Fame of the best individuals that lived in the population 
Benchmark modules containing most common test functions are included in the DEAP framework. It also includes several alternative algorithms, such as Particle Swarm Optimization, Differential Evolution, and Estimation of Distribution Algorithm.

The general implementation of DEAP as an optimization tool begins with assignment of proper type for the problem (using the creator module). Creator creates a new class from base classes defined in DEAP. The create() function takes at least two arguments; a name for the newly created class and a base class. Any subsequent argument becomes an attribute of the class. The types of fitness functions, individuals and populations are defined in this way.

Types created in DEAP are initialized, usually with random values. For example, an individual may be a list type. The elements in the list can be generated with some random number generation. Populations are similarly generated from individuals by applying population generation tools from the Toolbox. The Toolbox contains several initialization functions for individuals and populations as well as evolutionary operators and can be populated with any other function using the register( ) method.

Operators are similar to initializers, except that they are already implemented in the tools module. The selected operator is registered in the toolbox (using register method) before subsequent usage in the evolutionary process. During evolution, operators enable individuals to mutate or interact with each other via crossover. Selection operators are used to select fit individuals from the population. Some of the various operators implemented in DEAP are summarized Appendix 9.

The algorithms module in DEAP contains algorithms for the execution of common evolutionary algorithms (i.e., simple evolutionary algorithm, $(\mu+\lambda)$ 
evolutionary algorithm, $(\mu, \lambda)$ evolutionary algorithm and the generate-update algorithm). However, these algorithms are only the most common ones and sometimes they may not serve the desired particular evolution. After defining types, initialization and selection of desired operators, a personalized evolutionary algorithm is written, usually in a main( ) function. Examples of implementations of DEAP and methods associated with DEAP classes can be found in DEAP's user manual. 


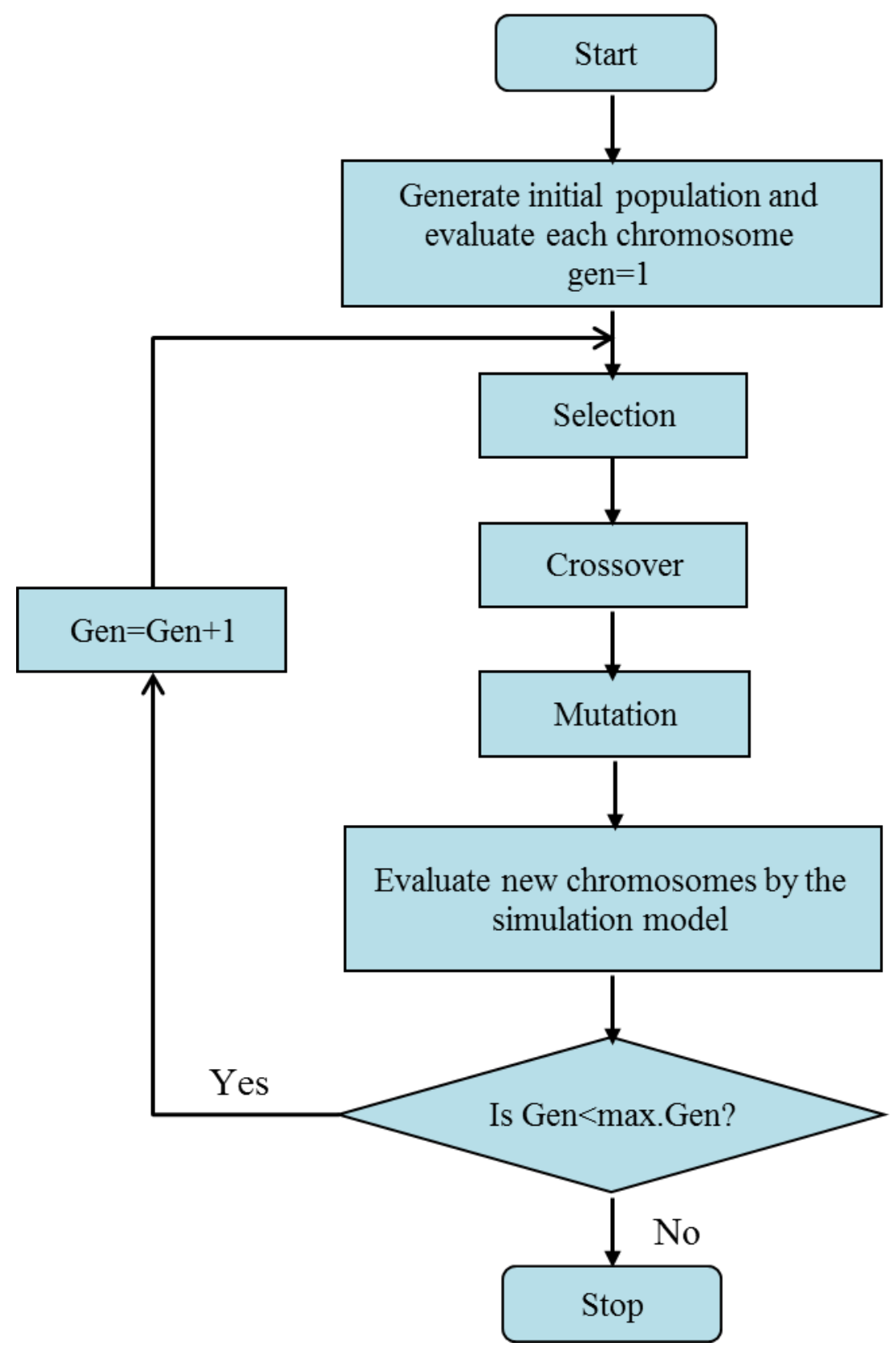

Figure 7.2 Flow chart of linked simulation-optimization processes 


\subsection{Application to the case of Coconut Grove, Miami}

The management method is applied on a 2D cross section of the Biscayne Aquifer in Coconut Grove. The model, described in detail in Langevin (2001), was designed to simulate local groundwater discharge to the Biscayne Bay in Southeastern Florida. The $8000 \mathrm{~m}$ by $40 \mathrm{~m}$ vertical cross-section model was discretized into $200 \mathrm{~m}$ by $2 \mathrm{~m}$ cells (Figure 7.3). A constant-flux boundary on the left represents groundwater flow from inland areas towards the coast and it is based on hydraulic conductivities and gradients in the Biscayne Aquifer. This flux is distributed evenly to each of the model cells. The lowest layer represents the base of the Biscayne Aquifer and is assigned a no-flow boundary. Constant-head and constant-salinity boundaries on the right represent the ocean boundary. Langevin (2001) represented the Biscayne Bay with a horizontal constant-head and constant-salinity boundary. This detail is not included in the present model as detailing groundwater discharge was not the purpose. The model is simplified by using only a vertical boundary to represent the ocean. Thus the width of the model has been reduced to $6000 \mathrm{~m}$ while the discretization is kept the same. A net recharge of 38 $\mathrm{cm} /$ year was applied to the topmost layer representing contributions of recharge from rainfall, runoff and evapotranspiration.

Aquifer parameters and boundary stresses were assigned based on field investigations and model calibrations. The results of calibration in Table 7.2 are used in the present simulation. The aquifer parameters include hydraulic conductivities, dispersivities and effective porosity. Diffusion was assumed to be negligible.

The model is first run for a long time (30 years) under steady-state conditions to simulate the pre-management conditions in the aquifer. Management then begins from 
this distribution of head and salt concentration in the aquifer and applies various combinations of recharge and abstraction wells (i.e., combinations of different location, depth and flow rates for each well). The time frame of management is assumed to be 10 years.

The individual is a list of total chloride concentration in the aquifer, chloride concentration at the abstraction well as well as rate, location and depth of the pumping and recharge wells. In GA's terms, each chromosome is made of eight genes. A uniform random number generator is used to generate the initial population of individuals. The population is then sent to the Seawat_simulation function (see the script in Appendix 10) which solves for spatiotemporal distribution of state variables (i.e., head and salt concentration in the aquifer) based on the random genes. The results are sent back to NSGA-II which performs the processes of identifying and selecting the best individuals obeying the preset constraints. The fit individuals are sent to the function Seawat_simulation which updates the state variables and sends them back to NSGA-II. This procedure is repeated for the specified number of generations and the resulting Pareto-optimal set, containing the set of optimum well arrangements, is used in decision making for sustainable groundwater management.

The individual is a list of decision variables, [C, QA, QR, LA, LR, DA, DR, Ci]. $\mathrm{C}$ is the total salt concentration in the aquifer, QA and QR are abstraction and recharge rates, LA and LR are the location of recharge and abstraction wells, DA and DR are the depths of recharge and abstraction wells, $\mathrm{Ci}$ is the salt concentration at the location of the abstraction well. See Figure 7.4 for a schematic sketch of the decision variables. The individuals are constrained as shown in equations 7.1 to 7.6 . Constraints 7.1 to 7.3 are 
handled in the optimization process by selecting these variables within the bounds and by using bounded operators. The constraints in equation 7.4 to 7.7 are handled by adding a penalty term to the objective functions (Appendix 10). The penalty is based on deviations from the upper or lower bounds.

$$
\begin{gathered}
0<\mathrm{QA}, \mathrm{QR}\left(\mathrm{m}^{3} / \text { day }\right)<432 \\
0<\mathrm{LA}, \mathrm{LR}(\mathrm{m})<6000 \\
0<\mathrm{DA}, \mathrm{DR}(\mathrm{m})<40
\end{gathered}
$$

Total chloride, $C<2294$ tons (total for no-management case)

$$
L A>L R
$$

$$
Q R<Q A \text { (for abstraction-desalination-recharge scenario) }
$$

$$
\text { Concentration at abstraction location, } \mathrm{Ci}>0.5 * 35 \mathrm{~kg} / \mathrm{m}^{3}
$$

Parameters selected for the GA optimization were as follows: population size $=$ 100 , maximum generations $=100$, cross over probability $=0.9$ and mutation probability $=$ 0.0025. Flow rates were constrained between 0 and $432 \mathrm{~m}^{3} / \mathrm{d}$. The values of unit costs used in the multi-objective optimization are shown in Table 7.3. 


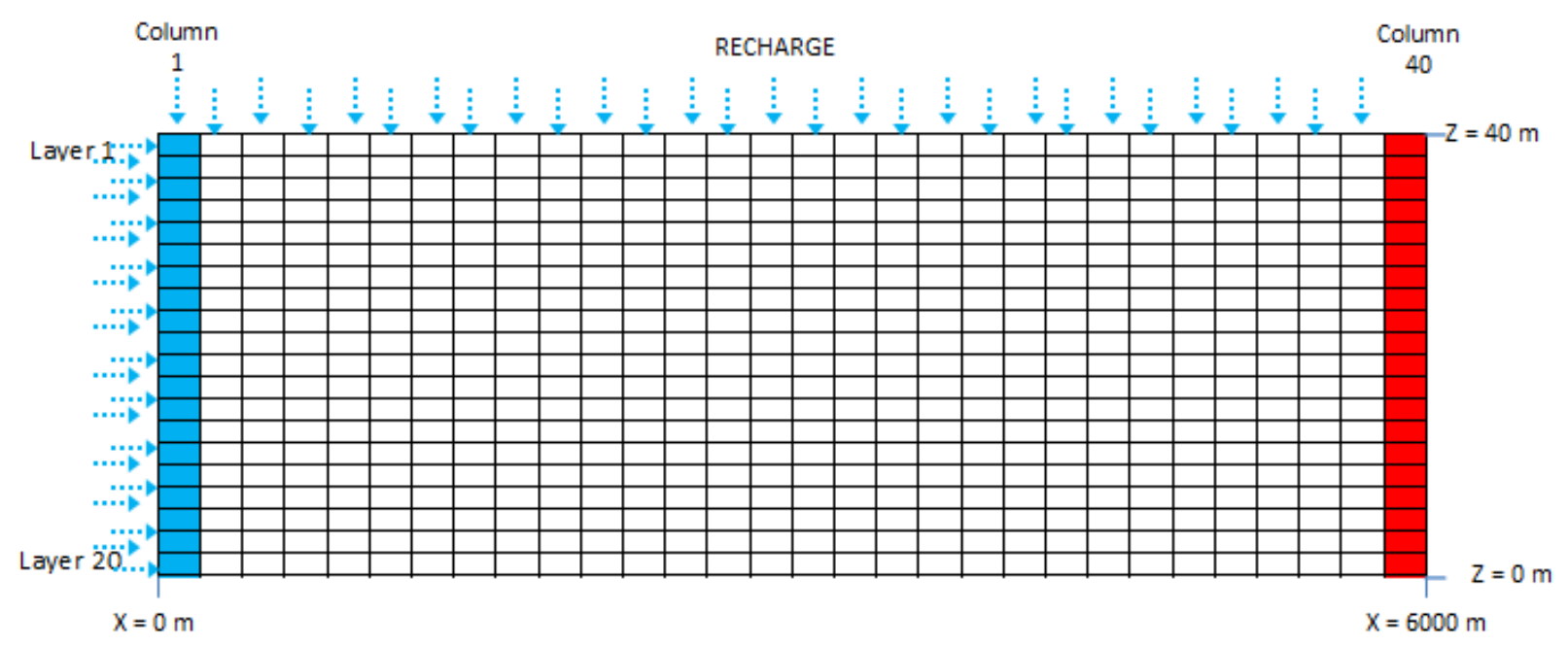

Figure 7.3 Model discretization and boundary conditions. Adapted from Langevin (2001) 


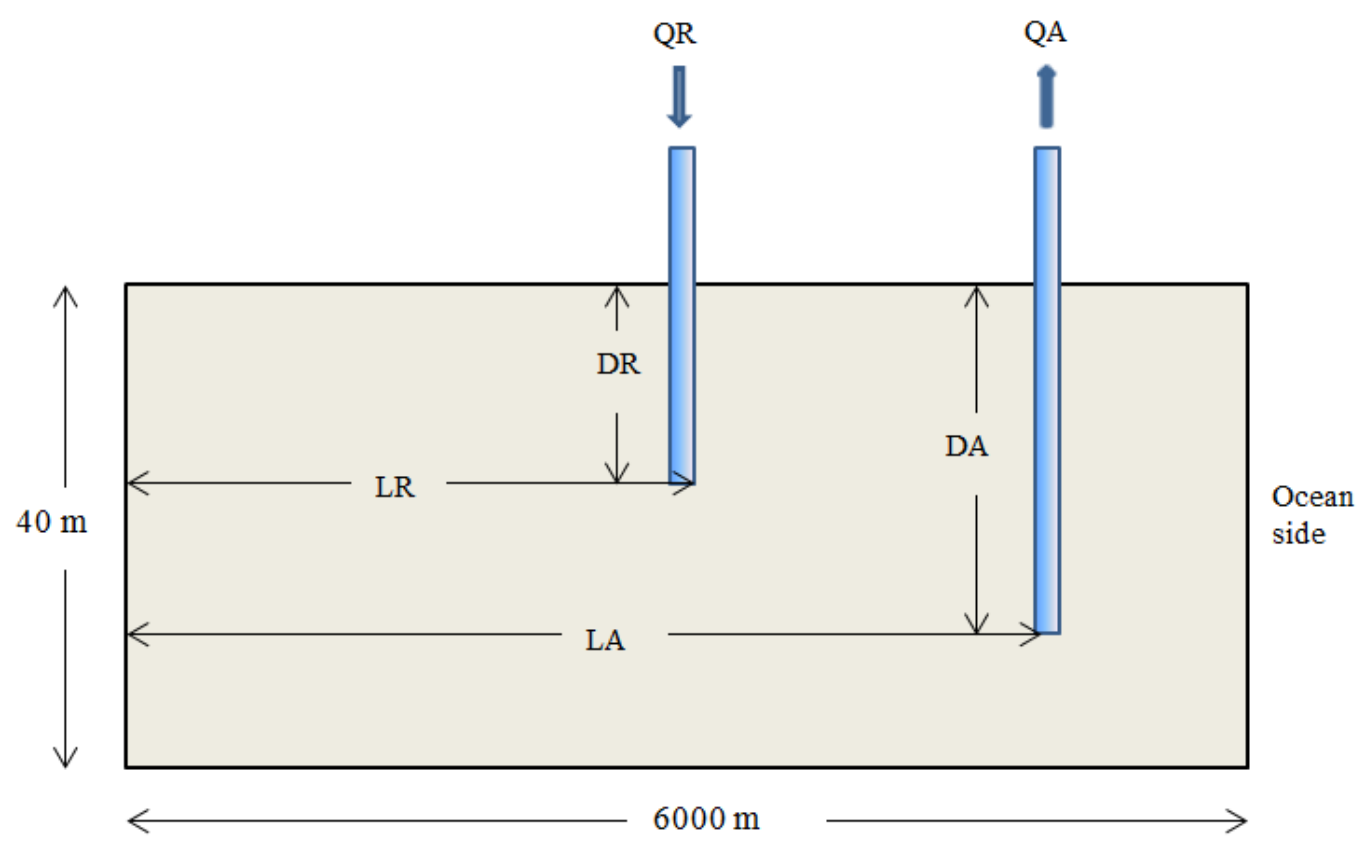

Figure 7.4 Schematic sketch of decision variables used in the management model

$\left(Q A=\right.$ rate of groundwater abstraction $\left(\mathrm{m}^{3} / \mathrm{d}\right) ; Q R=$ rate of aquifer recharge $\left(\mathrm{m}^{3} / \mathrm{d}\right) ; L A=$ location of abstraction well $(\mathrm{m}) ;$

$L R=$ location of recharge well (m); $D A=$ depth of abstraction well (m); $D R=$ depth of recharge well (m)) 
Table 7.2 Aquifer parameters and boundary stresses used in the calibrated cross-sectional model of Coconut Grove, Miami.

\begin{tabular}{|l|c|}
\hline Parameter/stress (units) & $\begin{array}{c}\text { Coconut Grove cross-sectional } \\
\text { model }\end{array}$ \\
\hline Horizontal hydraulic conductivity (m/d) & 9,000 \\
Vertical hydraulic conductivity (m/d) & 9 \\
Longitudinal dispersivity (m) & 1 \\
Transverse dispersivity (m) & 0.1 \\
Porosity (dimensionless) & 0.2 \\
Lateral influx (m/d) & 15 \\
Recharge (cm/year) & 38 \\
Density of seawater $\left(\mathrm{Kg} / \mathrm{m}^{3}\right)$ & 1025 \\
Density of freshwater $\left(\mathrm{Kg} / \mathrm{m}^{3}\right)$ & 1000 \\
Salt concentration of seawater $\left(\mathrm{Kg} / \mathrm{m}^{3}\right)$ & 35 \\
\hline
\end{tabular}

Table 7.3 Summary of the values of costs (Javadi et al., 2015).

\begin{tabular}{|l|c|}
\hline Parameter & Value \\
\hline Cost of abstraction $\left(\$ / \mathrm{m}^{3}\right)$ & 0.42 \\
Cost of recharge $\left(\$ / \mathrm{m}^{3}\right)$ & 0.48 \\
Cost of desalination $\left(\$ / \mathrm{m}^{3}\right)$ & 0.60 \\
Cost of installation/drilling of a well $(\$ / \mathrm{m} /$ year $)$ & 100 \\
Market price of desalinated water $\left(\$ / \mathrm{m}^{3}\right)$ & 1.5 \\
\hline
\end{tabular}




\subsection{Results and discussion}

The result of pre-management simulation is shown in the color map of Figure 7.5. Saltwater has encroached inland along the base of the aquifer and the toe of the $15 \mathrm{Kg} / \mathrm{m}^{3}$ isoconcentration line is about $3 \mathrm{Km}$ inland of the ocean boundary. Also shown is the 0.5 $\mathrm{Kg} / \mathrm{m}^{3}$ isoconcentration which is the maximum TDS concentration allowed in drinking water. TDS standards are thus met only at locations more than $4 \mathrm{Km}$ from the ocean.

A recharge and a pumping well were added to the pre-management model. This model was used in the linked simulation and optimization methods of the ADR management scenario. The computational time of the simulation-optimization analysis was about 8 hours on an Intel(R) Core(TM)2 Duo CPU @ 3.16GHz with 4.00 GB RAM. The results of ADR methodology show that the technique functions well in minimizing salt concentration and increasing available freshwater in the aquifer (Figure 7.7). The Pareto of solutions for the tradeoff between economic cost and total salt concentration shown in Figure 7.6 are obtained after 100 generations. The left most point corresponds to the most expensive solution with the least environmental cost; the right most point corresponds to the least expensive solution with the most environmental cost. All other points on the Pareto front are located between those two extreme solutions. Negative costs indicate revenues obtained from selling desalinated water after covering the costs of installation and pumping. Additional fixed costs such as wellhead costs, desalination plant capital costs are not included; the costs may therefore not be the true costs of management but can be used to compare different management scenarios.

A number of trade-off solutions are possible depending on weather economic cost or environmental cost is given higher weight. Figure 7.7 (top) shows TDS distribution for 
the point $(1565,-69,563)$ in the Pareto front of Figure 7.6. The toe of the $0.5 \mathrm{Kg} / \mathrm{m}^{3}$ contour is shifted by about $700 \mathrm{~m}$ towards the ocean. The relatively small reduction of TDS is compensated by higher revenue of $\$ 69,563$ per year because water is pumped at the maximum rate $\left(432 \mathrm{~m}^{3} / \mathrm{d}\right)$ and almost all of the desalinated water is sold for municipal purposes. Figure 7.7 (bottom) shows TDS distribution for the point $(526,-28,579)$ in the Pareto front; there is less salt concentration in the aquifer than that in Figure 7.7 (top) but this management is achieved at a higher cost (lower revenue). The $0.5 \mathrm{Kg} / \mathrm{m}^{3}$ contour line is shifted sea-ward by about $3 \mathrm{Km}$ until it is only $1 \mathrm{Km}$ from the coastal boundary; this shows that a large part of the intruded area can effectively be reclaimed with the management method tested. 


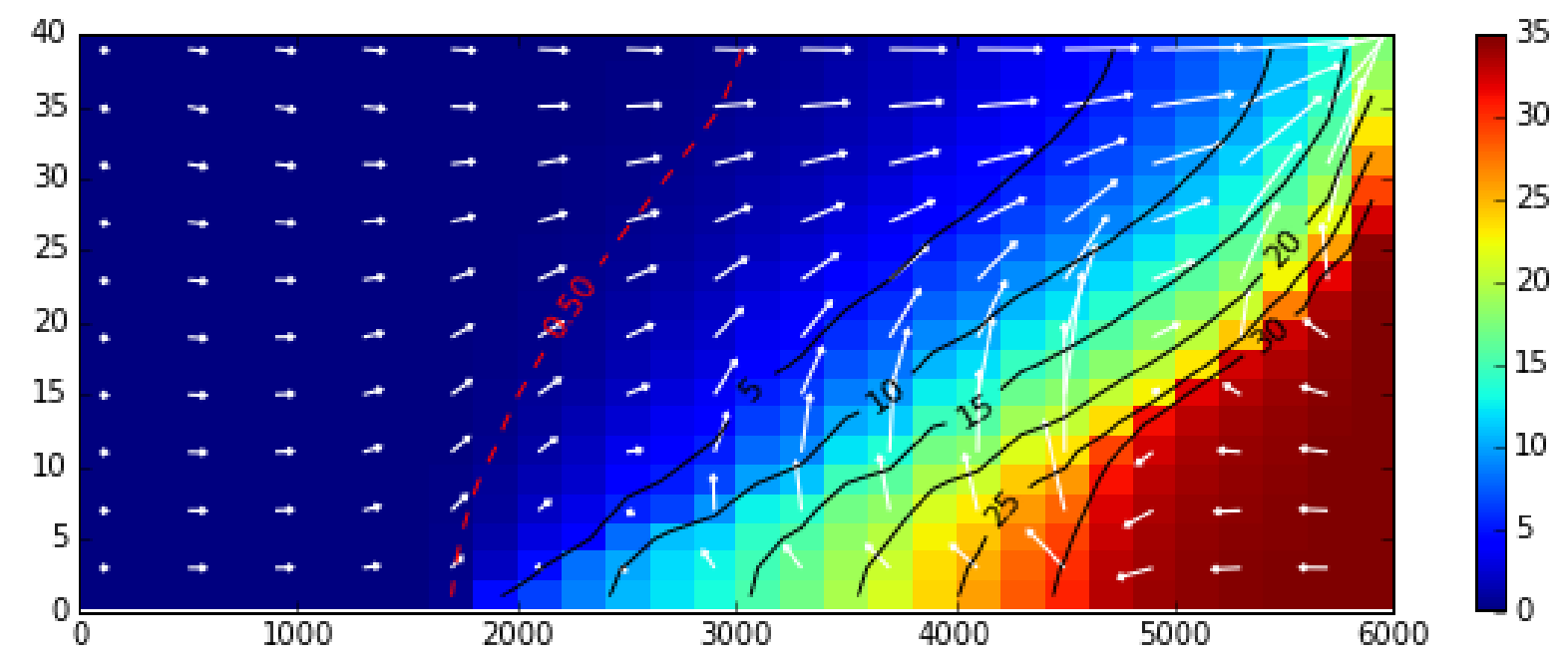

Figure 7.5 TDS in the steady-state pre-management simulation. Concentrations are shown in $\mathrm{Kg} / \mathrm{m}^{3}$. White arrows indicate flow velocity vectors. The 0.5 isoconcentration contour is the EPA secondary drinking water standard for TDS. 


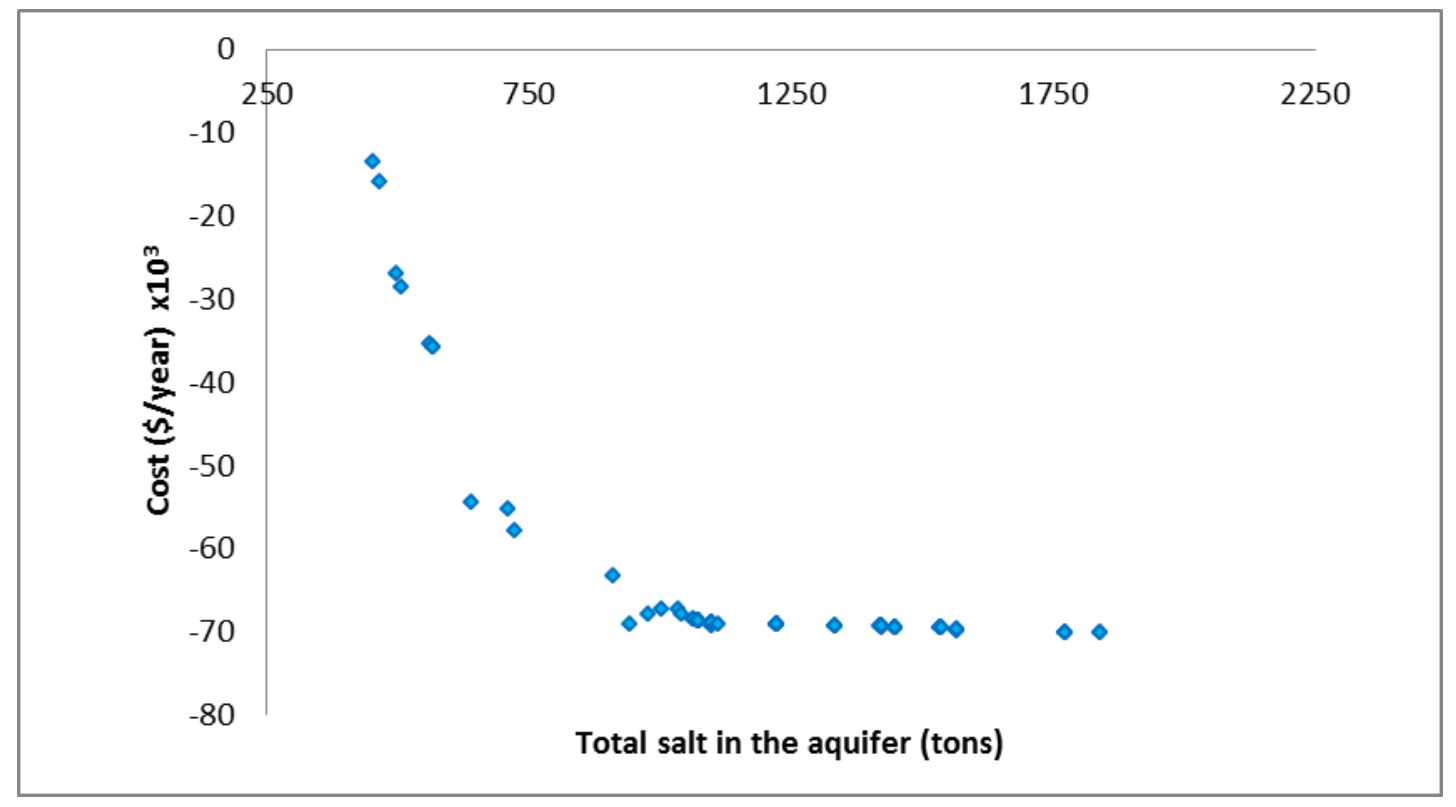

Figure 7.6 Pareto-front of solutions to the ADR management problem 

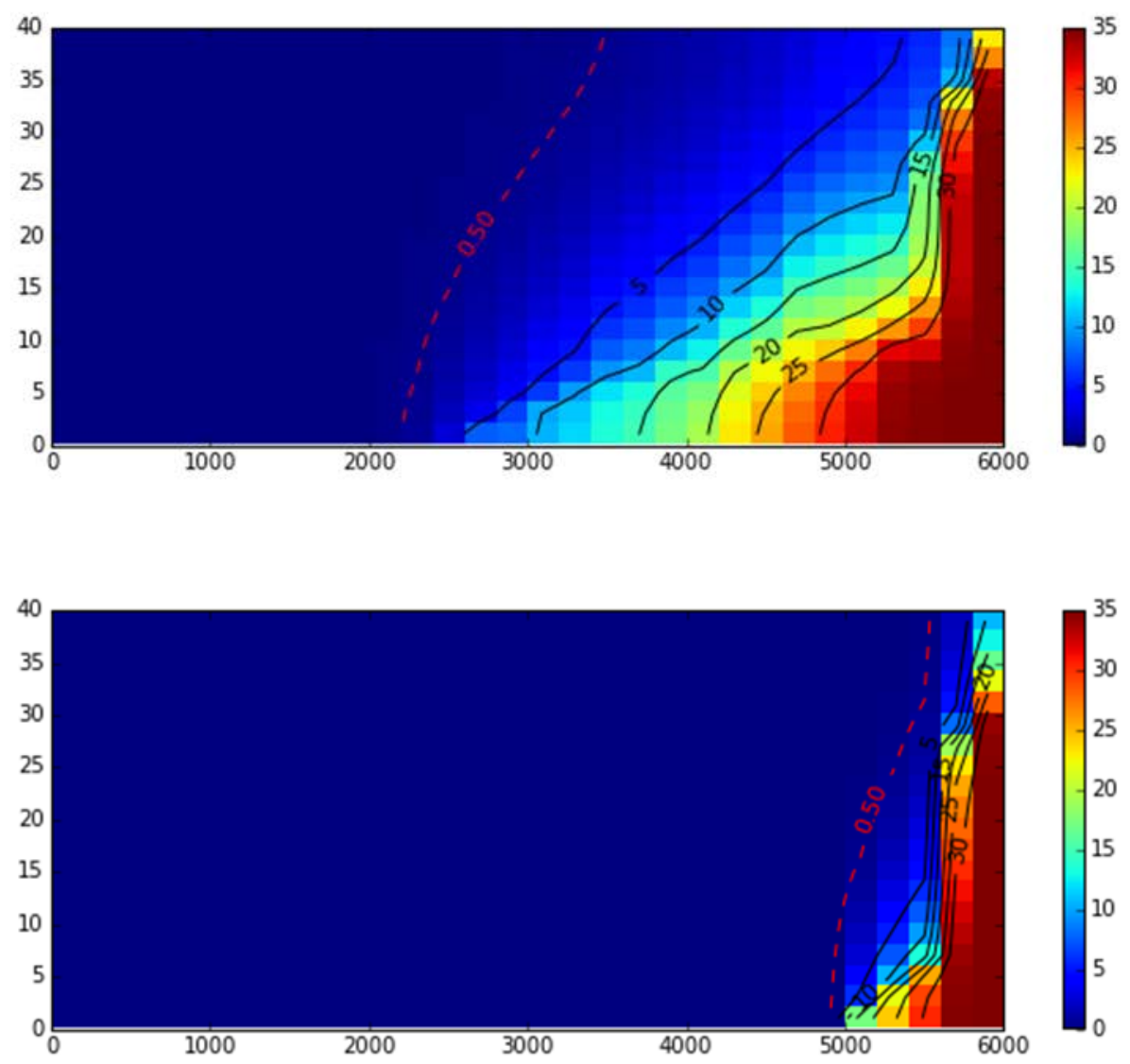

Figure 7.7 Salinity (TDS) distribution after application of the ADR management model for select individuals in the Pareto front. [1565, 432, 1, 5800, 400, 32, 22, 34.6] (top) and ADR [526, 430.4, 54, 5800, 400, 40, 38, 34.7] (bottom).

Associated benefits are $\$ 69,563$ and $\$ 28,579$, respectively . 
The ADR management of Figure 7.7 is applied for an assumed management time frame of 10 years. Transient simulations of salt concentrations are shown in Figure 7.8 after application of the ADR management to the case of Figure 7.7 (top). The TDS contours in Figure 7.8 change with time until about ten years but they remain the same afterwards, supporting the selection of a time frame of 10 years where ADR is effective.

In another scenario, the management is assumed to use only injection wells where the aquifer is recharged with desalinated water. In this case there is no revenue from selling desalinated water and higher costs of management are obtained when compared to ADR (Figure 7.9). Furthermore, the effect of reduced lateral influx due to limited precipitation in upstream areas is modeled. Assuming lateral influx is reduced by a factor of 4 (i.e., using influx of $15 / 4 \mathrm{~m}^{3} / \mathrm{d}$ ), management costs increase because of the higher recharge rates required in the ADR management. Figure 7.9 shows that the ADR method provides a cost-effective SWI management and that management cost increases when precipitation is reduced. 

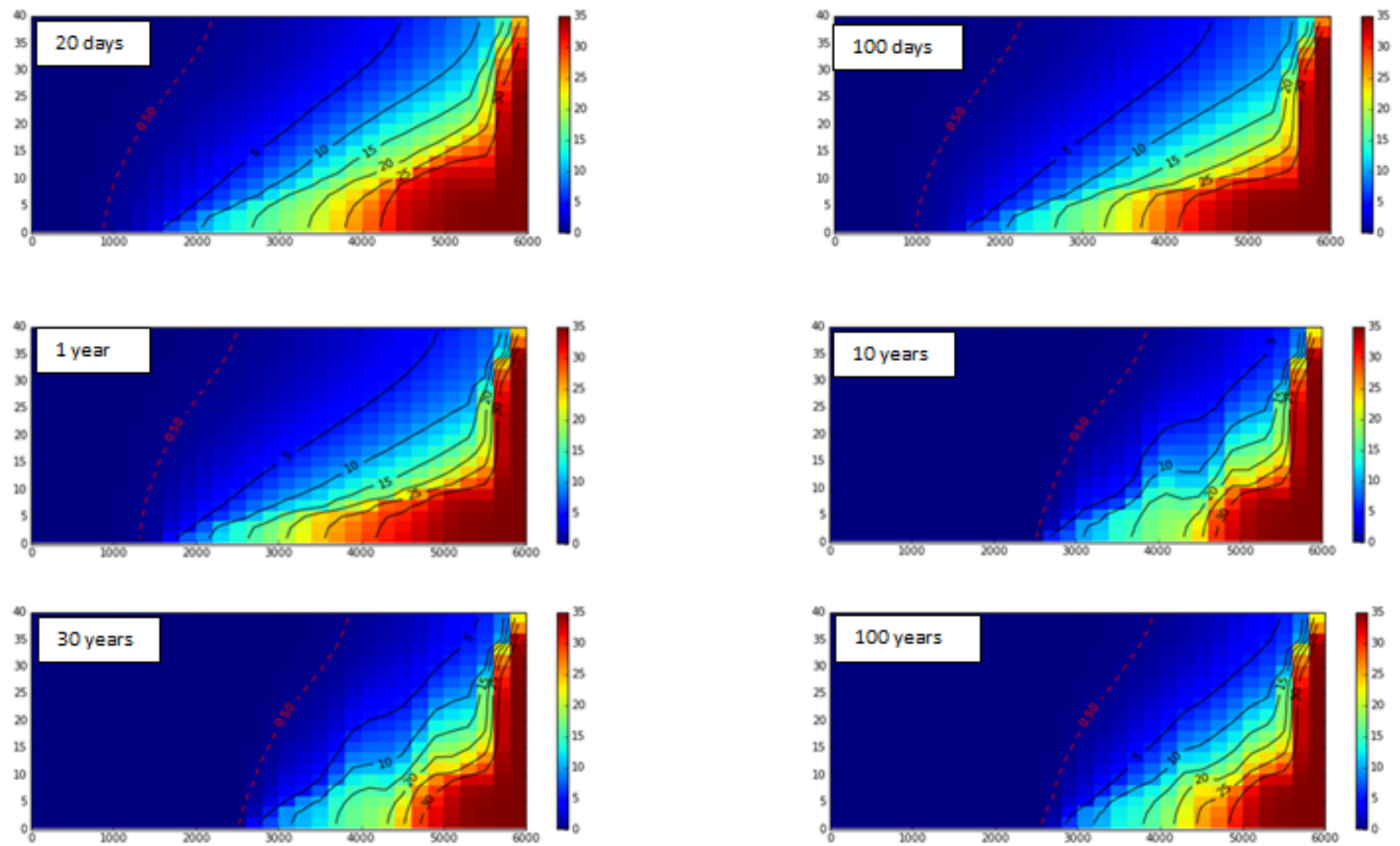

Figure 7.8 Transient simulations of TDS for the ADR management with the individual [1565, 432, 1, 5800, 400, 32, 22, 34.6]. TDS distributions remain the same after 10 years of management. 


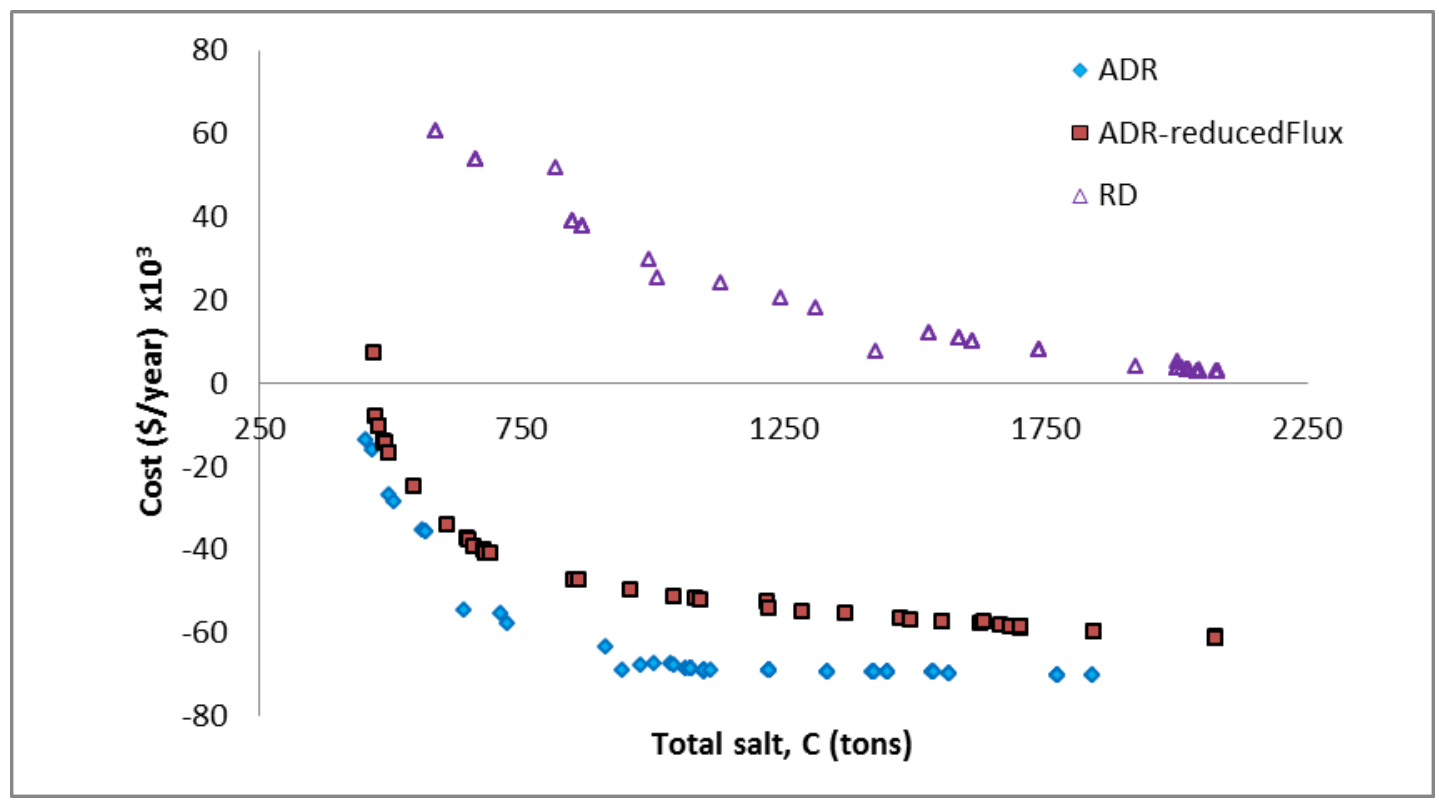

Figure 7.9 Pareto solutions of different SWI management scenarios. RD stands for recharge with desalinated water; ADR is abstraction-desalination-recharge method.

\subsection{Summary and conclusion}

A saltwater management plan for a cross-section of the Biscayne Aquifer is presented. The ADR management plan involves (1) abstraction of brackish water, (2) desalination of abstracted water and (3) recharge with part of the desalinated water. The problem is formulated into a multi-objective optimization problem where both economic and environmental costs of the management are minimized, while satisfying limiting constraints of abstraction and recharge. The multi-objective optimization problem was solved using a linked simulation and optimization method in a Python framework.

The methodology was applied to the case of Coconut Grove in Miami where the pre-management toe of the $0.5 \mathrm{Kg} / \mathrm{m}^{3}$ halocline was located about $4200 \mathrm{~m}$ inland from the coast. As a result of the optimization strategy, a set of optimum locations, depths and flow rates for each well were obtained that satisfied the multi-objective criteria. The 
decision maker can then choose the most suitable solution for a desired environmental or economic cost. By applying the ADR management strategy, movement of the seawater is reversed back to the ocean side by up to $3000 \mathrm{~m}$ for some of the optimal solutions.

\section{References}

Abd-Elhamid, H.F. and Javadi, A.A. (2011). A cost-effective method to control seawater intrusion in coastal aquifers. Water Resour. Manage., 25(11); 2755-2780.

Baker, M., Post, V., Langevin, C., Hughes, J., White, J., Frances, A., Fienen, M. and Starn, J. (2015). FloPy3: a Python package to create, run, and post-process MODFLOW-based models. GitHub repository, https://github. com/modflowpy/flopy 2015.

Bhattacharjya, R.K. and Datta, B. (2009). ANN-GA-based model for multiple objective management of coastal aquifers. J. Water Resour. Plann. Manage., 135(5); 314-322.

Deb, K., Pratap, A., Agarwal, S. and Meyarivan, T. (2002). A fast and elitist multiobjective genetic algorithm: NSGA-II. Evolutionary Computation, IEEE Transactions on, 6(2); 182-197.

Dhar, A. and Datta, B. (2009). Saltwater intrusion management of coastal aquifers. I: Linked simulation-optimization. J. Hydrol. Eng., 14(12); 1263-1272.

Holland, J. (1975). Adaptation in artificial and natural systems. Ann Arbor: The University of Michigan Press.

Javadi, A., Hussain, M., Sherif, M. and Farmani, R. (2015). Multi-objective optimization of different management scenarios to control seawater intrusion in coastal aquifers. Water Resour. Manage., 29(6); 1843-1857.

Ketabchi, H. and Ataie-Ashtiani, B. (2015a). Evolutionary algorithms for the optimal management of coastal groundwater: A comparative study toward future challenges. Journal of Hydrology, 520(2015); 193-213.

Ketabchi, H. and Ataie-Ashtiani, B. (2015b). Review: Coastal groundwater optimization—advances, challenges, and practical solutions. Hydrogeol. J.; 1-26.

Konak, A., Coit, D.W. and Smith, A.E. (2006). Multi-objective optimization using genetic algorithms: A tutorial. Reliab. Eng. Syst. Saf., 91(9); 992-1007. 
Kourakos, G. and Mantoglou, A. (2013). Development of a multi-objective optimization algorithm using surrogate models for coastal aquifer management. Journal of Hydrology, 479; 13-23.

Kourakos, G. and Mantoglou, A. (2011). Simulation and multi-objective management of coastal aquifers in semi-arid regions. Water Resour. Manage., 25(4); 1063-1074.

Langevin, C.D. (2001). Simulation of Ground-water discharge to Biscayne Bay, Southeastern Florida. U. S. Geological Survey Water-Resources Investigations Report 00-4251.

Park, C. (2004). Saltwater intrusion in coastal aquifers. http://hdl.handle.net/1853/4857 last accessed on May 5, 2005.

Qahman, K., Larabi, A., Ouazar, D., Ahmed, N. and Alexander, H.C. (2009). Optimal extraction of groundwater in Gaza coastal aquifer. Journal of Water Resource and Protection, 1(04); pp. 249.

Qahman, K., Larabi, A., Ouazar, D., Naji, A. and Cheng, A.H. (2005). Optimal and sustainable extraction of groundwater in coastal aquifers. Stochastic Environmental Research and Risk Assessment, 19(2); 99-110.

Singh, A. (2015). Managing the environmental problem of seawater intrusion in coastal aquifers through simulation-optimization modeling. Ecol. Ind., 48; 498-504.

Singh, A. (2014). Optimization modelling for seawater intrusion management. Journal of Hydrology, 508; 43-52.

Sreekanth, J. and Datta, B. (2015). Review: Simulation-optimization models for the management and monitoring of coastal aquifers. Hydrogeol. J., 23(6); 1155-1166.

Sreekanth, J. and Datta, B. (2014). Stochastic and robust multi-objective optimal management of pumping from coastal aquifers under parameter uncertainty. Water Resour. Manage., 28(7); 2005-2019.

Sreekanth, J. and Datta, B. (2011a). Comparative evaluation of genetic programming and neural network as potential surrogate models for coastal aquifer management. Water Resour. Manage., 25(13); 3201-3218.

Sreekanth, J. and Datta, B. (2011b). Coupled simulation optimization model for coastal aquifer management using genetic programming based ensemble surrogate models and multiple-realization optimization. Water Resour. Res., 47(4); 1-17. 
Sreekanth, J. and Datta, B. (2010). Multi-objective management of saltwater intrusion in coastal aquifers using genetic programming and modular neural network based surrogate models. Journal of Hydrology, 393(3); 245-256.

Werner, A.D., Bakker, M., Post, V.E., Vandenbohede, A., Lu, C., Ataie-Ashtiani, B., Simmons, C.T. and Barry, D.A. (2013). Seawater intrusion processes, investigation and management: Recent advances and future challenges. Adv. Water Resour., 51; 3-26. 


\section{CONCLUSIONS AND RECOMMENDATIONS}

\subsection{Summary and conclusions}

The dissertation objectives were to evaluate water quality changes during saline intrusion in the Biscayne Aquifer, to develop a reactive transport model to assess fate and transport of regulated trace metals during ASR operations in South Florida, and to implement an optimization model to obtain a cost-effective management solution to saltwater intrusion in the Biscayne Aquifer. Saltwater-induced water quality changes in the Biscayne Aquifer were analyzed. Water supply augmentation through ASR commonly uses the UFA for storage. Water quality changes, including trace metal mobilization, were modeled in the UFA for the case of the Kissimmee River ASR.

The first chapter introduced the state-of-the art on water quality changes during saltwater intrusion and artificial aquifer recharge. The problem of saltwater intrusion in the Biscayne Aquifer was introduced and a number of geochemical reactions that can occur in mixing zones were presented. Dissolution-precipitation, ion exchange and surface complexation reactions are among the most common reactions in mixing zones and have been discussed in detail. ASR was presented as a water supply augmentation strategy where water is stored during wet periods to be used when needed during periods of high demand. ASR operations may result in recovered water with quality significantly different from that of the injected water. These changes affect the recovery efficiency of ASRs and, more importantly, the release mechanisms of trace metals (such as As).

Background water quality and associated water-rock interactions were first characterized for the Biscayne Aquifer and the UFA. In the third chapter, hydrogeochemical processes that accompany seawater intrusion in the Biscayne Aquifer 
were evaluated. The presence of dissolution-precipitation reactions and ion exchange in the mixing zone of the Biscayne Aquifer are suggested based on changes in major ion concentrations and mineral saturation indices (SI). Water quality of the samples from the mixing zone is mainly attributed to mixing and precipitation-dissolution reactions with calcite and dolomite. The samples were saturated with calcite and mainly unsaturated with dolomite. Gypsum and halite behaved conservatively and reactions with those minerals are believed to be insignificant. In the active-intrusion areas, cation exchange also appears to modify water quality, leading to excess $\mathrm{Ca}^{2+}$, but depleted $\mathrm{Na}^{+}, \mathrm{Mg}^{2+}$ and $\mathrm{K}^{+}$concentrations. On the other hand, samples from previous-intrusion areas plotted very close to the theoretical mixing line and approached equilibrium with seawater.

Mobilization of trace metals during ASR is a big concern in South Florida. Bench scale studies show the possibility of mobilization of uranium (U) from aquifers when oxidized water is injected into the aquifer. In the fourth chapter, $\mathrm{U}$ speciation due to groundwater mixing in the Biscayne Aquifer and the Upper Floridan Aquifer is modeled. Groundwater samples near the saltwater interface of the Biscayne Aquifer and from KRASR were used in modeling. Results of speciation modeling indicate that calciumuranyl carbonates $\left(\mathrm{Ca}_{2} \mathrm{UO}_{2}\left(\mathrm{CO}_{3}\right)_{3}\right.$ and $\left.\mathrm{CaUO}_{2}\left(\mathrm{CO}_{3}\right)_{3}{ }^{2-}\right)$ dominate over the near-neutral $\mathrm{pH}$ range of the Biscayne Aquifer samples, making up more than 98\% of the species. Mixing simulations of ASR resulted in $\mathrm{pH}$ of 6.70 to 7.97 and calcium-uranyl carbonates dominated the speciation. Changes in redox potential and $U$ concentration (up to $30 \mu \mathrm{g} / \mathrm{L}$ ) in groundwater appeared to have negligible effects on speciation, as Ca-uranyl carbonates remained dominant. Fate of $\mathrm{U}$ may thus be predominantly described by that of the highly 
mobile Ca-uranyl carbonates over the neutral to alkaline $\mathrm{pH}$ of carbonate aquifers for the expected ranges of concentration.

As a storage aquifer for ASR in South Florida, characterization of the UFA's water quality forms a good base in modeling water quality changes associated with ASR. In Chapter 5, UFA water quality is evaluated in terms of mixing and water-rock interactions. Ionic analyses and mineral saturation index computations were used to infer determinants of water quality in the UFA on a regional scale. Groundwater samples were obtained from a combination of monitoring, production and recharge wells in the aquifer. Salinity and constituent concentrations generally increased with depth and resulted mainly from mixing of recharge water with seawater. Most samples were saturated with calcite and dolomite and these minerals had the tendency to precipitate. Dissolution of gypsum in deeper aquifers was predicted based on SI of gypsum in the FAS samples.

Following characterization of the UFA, a reactive transport model was set up to simulate the evolution of water quality during ASR cycle tests. The model was calibrated to measured constituent concentrations during the first cycle tests at the KRASR site. A 3D rectangular model was set up with boundary conditions closely approximating field conditions. Major ions, such as $\mathrm{Cl}^{-}, \mathrm{Na}^{+}, \mathrm{K}^{+}, \mathrm{Mg}^{2+}$ and sulfate, were sufficiently modeled by a conservative transport model that neglected water-rock reactions in the aquifer. Inclusion of calcite dissolution-precipitation reactions was necessary to reasonably model $\mathrm{Ca}^{2+}$ and alkalinity concentrations in the ASR and a nearby monitoring well. A more complex network of mineral equilibrium, kinetic and surface complexation reactions was incorporated to model the fate of trace metals (i.e., Fe, and As). Taking into account the inherent difficulty of predicting and simulating all possible reactions, the trends of trace 
metal concentrations during various phases of the cycle tests were closely estimated by the model. Generally, the model showed excellent correlation with respect to most of the constituents measured at the ASR well. A combination of PEST and PHAST codes was powerful in evaluating and predicting water quality changes at different stages of the ASR cycle. $\mathrm{pH}$ and trace metal concentrations were predicted lower than measured values at the monitoring well. Besides complex interactions of chemical processes affecting the fate of trace metals, the low concentrations modeled may be due to difficulty of modeling the actual flow conditions in the highly heterogeneous aquifer. A dual-porosity model, including mobile and immobile phases of the aquifer, is an option that should be considered to assess its effectiveness in describing the fate of trace metals at KRASR. Importantly, modeling of trace metals (i.e., Fe and As) can be improved with detailed hydrogeochemical characterization in the field, such as measuring mineral composition of the aquifer (pyrite, ferric oxides, etc.), cation exchange capacities, as applicable, and potential of surface complexation of any mineral with specific metals.

In the last chapter, a cost-effective management of saltwater intrusion in the Biscayne Aquifer is presented. The method uses a combination of abstraction and recharge wells where saline water is abstracted and desalinated. Part of the desalinated water is used for municipal supply while the remaining is used to recharge the aquifer. A linked simulation-optimization model was used to optimize the management process, which seeks the most effective combination of well locations and recharge/abstraction rates that minimize total environmental and economic costs. A set of optimum solutions to the saltwater management problem was obtained. The abstraction-desalinationrecharge method was found to be effective in 'pushing' back the saltwater interface. 
Under this method, the toe of the $500 \mathrm{mg} / \mathrm{L}$ halocline shifted seaward by more than 3000 $\mathrm{m}$ until it was only $1000 \mathrm{~m}$ from the coast. Assuming that reduced precipitation in upstream recharge areas led to reduced lateral influx of water, as a consequence of climate change, enhanced inland movement of the saltwater interface was observed. Reduction of lateral influx by a quarter increased economic costs by an average of $\$ 15,000$ per year when environmental costs are held constant.

\subsection{Recommendations for future work}

- The hydrogeochemical modeling of saltwater intrusion predicted the most common geochemical reactions in the mixing zone as related to inorganic ions. The work can be extended by including organic constituents and redox-influenced ions such as trace metals. The samples for geochemical modeling were collected near the saltwater front and the results were averaged over the area of intrusion. More detailed analysis of geochemical evolution can be done in a local scale by installing monitoring wells along a flow line that is perpendicular to the coast and by collecting temporal data. This would give a better insight into spatial and temporal geochemical evolution of saltwater intrusion in the Biscayne Aquifer.

- In modeling fate and transport of trace elements during ASR, cycle test data can be complemented by laboratory leaching studies using similar recharge water and aquifer materials as in the field. The laboratory tests would allow focused analyses of the influence of some process parameters by keeping other parameters constant. The leaching behavior of uranium, for example, is best studied in a laboratory setting because field ASR measurements report very low concentrations that are occasionally below detection levels. 
- The KRASR modeling used treated surface water for recharge. Recharge with treated wastewater can also be tested to see how water quality evolves with respect to constituents such as nitrates. In this case, decay of organic matter and biogeochemical reactions play an important role in relation to the possibility of well clogging. The study and findings can have important implications on the recovery efficiency of ASR with wastewater and on well operation and maintenance costs.

- The simulation-optimization methodology used in the saltwater management introduces computational time burden, which is due to the repeated calls to the SEAWAT simulator. This computational time can be significantly reduced by training an artificial neural network (ANN) and using the trained ANN as a simulator. The ANN may not perfectly replace the simulator but it can significantly reduce the computational time. Furthermore, a number of simplifying assumptions have been used in the cross-section method and the configuration is a very simplified representation of actual field conditions. A more reasonable representation of field conditions can clearly be done by using a 3D model including realistic field stresses, such as a series of wells, canals and rivers. 
APPENDICES 


\section{Appendix 1 - PEST control file used in calibrating KRASR reactive transport model}

to observed heads

Appendix 1 supports the PEST calibration input files described in section 6.5.2.1 and

Figure 6.5. PEST input files include a control file, a template file, and an instruction file.

The control file defines the parameters to be estimated, optimization methods and observation data groups. 
pcf

* control data

restart estimation

827201

11 single point 100

10.02 .00 .30 .0310

3.03 .00 .001

0.1

300.001330 .013

111

* parameter groups

k1 relative 1e-2 0.000001 switch 2 parabolic

s1 relative 1e-2 0.000001 switch 2 parabolic

* parameter data

k1 log relative 300100600 k1 1.00 .01

k2 tied relative $300100600 \mathrm{k} 11.00 .01$

k3 tied relative $301060 \mathrm{k} 11.00 .01$

k4 log relative $7550150 \mathrm{k} 11.00 .01$

k5 tied relative 7550150 k1 1.00 .01

k6 tied relative $7.5515 \mathrm{k} 11.00 .01$

s1 log relative 2e-6 1e-6 3e-6 s1 1.001

s2 log relative 2e-6 1e-6 3e-6 s1 1.001

k2 k1

k3 k1

k5 k4

k6 k4

* observation groups

group_1

* observation data

c1 14.71 group_1

c2 18.01 group_1

c3 18.11 group_1

c4 18.21 group_1

c5 15.01 group_1

c6 14.91 group_1

c7 14.91 group_1

c8 11.41 group_1

c9 11.41 group_1

c10 10.91 group_1

c11 10.91 group_1

c12 14.01 group_1

c13 14.01 group_1

c14 14.01 group_1

c15 17.0 1 group_1

c16 16.81 group_1 
c17 16.81 group_1

c18 16.81 group_1

c19 16.81 group_1

c20 16.81 group_1

c21 16.51 group_1

c22 16.41 group_1

c23 16.81 group_1

c24 16.81 group_1

c25 16.81 group_1

c26 14.91 group_1

c27 14.91 group_1

* model command line

phast KRASR0415 phast.dat

* model input/output

C:\KRASRheadCalibration4\KRASR0415.tpl

C:\KRASRheadCalibration4\KRASR0415.trans.dat

C:\KRASRheadCalibration4\KRASR0415.ins

C:IKRASRheadCalibration4\KRASR0415.head.txt 


\section{Appendix 2 - PEST template file used in calibrating KRASR reactive transport model to observed heads}

Appendix 2 supports the PEST calibration input files described in section 6.5.2.1 and

Figure 6.5. PEST input files include a control file, a template file, and an instruction file.

The template file is a copy of PHAST model input but with values of parameters replaced

by parameter variables within the template file symbol. For example, @k1 @ @ is a

place holder for parameter $\mathrm{k} 1$, which is replaced with estimated value of $\mathrm{k} 1$ in each

iteration. 
ptf@\# PEST fills parameters in between @ @

SOLUTE_TRANSPORT false -diffusivity 1e-009

STEADY_FLOW false

FREE_SURFACE_BC false

SOLUTION_METHOD

-iterative_solver true

-tolerance 1e-010

-save_directions 20

-maximum_iterations 500

-space_differencing 0

-time_differencing 1

-cross_dispersion true

-rebalance_fraction 0.5

-rebalance_by_cell false

UNITS

-time days

-horizontal_grid $\mathrm{ft}$

-vertical_grid $\quad \mathrm{ft}$

-map_horizontal $\mathrm{ft}$

-map_vertical $\mathrm{ft}$

-head ft

-hydraulic_conductivity ft/day

-specific_storage $\quad 1 /$ foot

-dispersivity $\mathrm{ft}$

-flux ft/day

-leaky_hydraulic_conductivity ft/day

-leaky_thickness ft

-well_diameter $\quad \mathrm{ft}$

-well_flow_rate gallon/day

-well_depth ft

-river_bed_hydraulic_conductivity ft/day

-river_bed_thickness

-river_width

-river_depth

$\mathrm{ft}$

-drain_hydraulic_conductivity ft/day

-drain_thickness

$\mathrm{ft}$

-drain_width

$\mathrm{ft}$

-equilibrium_phases

-exchange

WATER

-surface

-solid_solutions

-kinetics

GRID

-gas_phase

WATER

WATER

WATER

WATER

WATER 
-nonuniform X

$\begin{array}{lllllll}-3 & 0 & 2 & 4 & 6 & & \\ 8 & 10 & 15 & 20 & 25 & & \\ 30 & 40 & 50 & 60 & 70 & & \\ 80 & 90 & 100 & 150 & 200 & \\ 250 & 300 & 350 & 400 & 450 & \\ 500 & 550 & 600 & 700 & 800 & \\ 900 & 1000 & 1100 & 1200 & 1300 \\ 1350 & 1400 & 1450 & 1500 & 1600 \\ 1700 & 1800 & & & \end{array}$

-nonuniform $\mathrm{Y}$

$\begin{array}{lllll}-3 & 0 & 2 & 4 & 6\end{array}$

$\begin{array}{lllll}8 & 10 & 15 & 20 & 25\end{array}$

$\begin{array}{lllll}30 & 40 & 50 & 60 & 70\end{array}$

$\begin{array}{lllll}80 & 90 & 100 & 150 \quad 200\end{array}$

$\begin{array}{lllll}250 & 300 & 350 & 400 & 450\end{array}$

$\begin{array}{lllll}500 & 550 & 600 & 700 & 800\end{array}$

$\begin{array}{lllll}900 & 1000 & 1100 & 1200 & 1300\end{array}$

$\begin{array}{lllll}1350 & 1400 & 1450 & 1500 & 1600\end{array}$

17001800

-nonuniform Z

$\begin{array}{lllll}-1583 & -1516.5 & -1450 & -1300 & -1150\end{array}$

$\begin{array}{lllll}-1000.04 & -896.04 & -792.04 & -766.48 & -740.92\end{array}$

$\begin{array}{lllll}-715.36 & -689.8 & -664.24 & -638.68 & -613.12\end{array}$

$\begin{array}{lllll}-587.56 & -562 & -556 & -549 & -542\end{array}$

$\begin{array}{llll}-403 & -264 & -125 & 40\end{array}$

-snap X 0.001

-snap Y 0.001

-snap Z 0.001

-chemistry_dimensions XYZ

-print_orientation XY

-grid_origin $-3 \quad-30$

MEDIA

-grid_angle 0

-domain

-active $\quad 1$

-Kx $\quad 0.0001$

-Ky $\quad 0.0001$

$-\mathrm{Kz} \quad 1 \mathrm{e}-005$

-porosity $\quad 0.25$

-specific_storage $\quad 0.0001$

-long_dispersivity 2.5

-horizontal_dispersivity 0.25

-vertical_dispersivity 0.25

-box -3 -3 -542 18001800 -125 GRID 


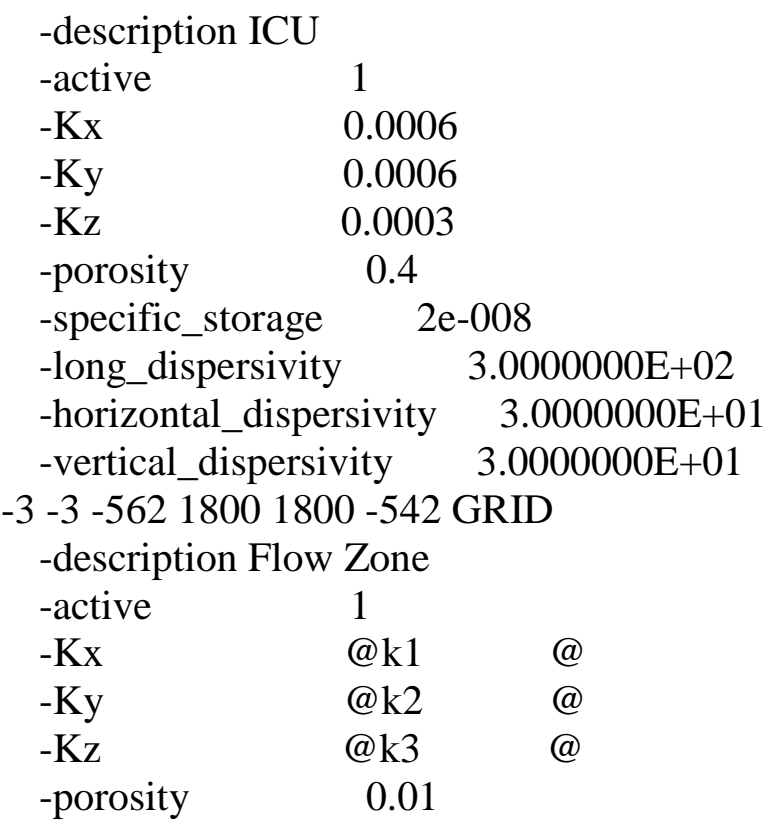

\begin{tabular}{|c|c|}
\hline -specific_storage & @ \\
\hline -long_dispersivity & $3.0000000 \mathrm{E}+02$ \\
\hline -horizontal_dispersivity & $3.0000000 \mathrm{E}+01$ \\
\hline -vertical_dispersivity & $3.0000000 \mathrm{E}+01$ \\
\hline
\end{tabular}

-box -3 -3 -792.039978027344 18001800 -562 GRID

-description UFA

-active

-Kx @k4@@

-Ky@@5 @

-Kz@@6@

-porosity 0.1

-specific_storage@@ @ @

-long_dispersivity 3.0000000E+02

-horizontal_dispersivity $3.0000000 \mathrm{E}+01$

-vertical_dispersivity $3.0000000 \mathrm{E}+01$

-box -3 -3 -1000.039978027341800 1800 -792.039978027344 GRID

-description MC1

-active 1

$-\mathrm{Kx} \quad 0.3$

$-\mathrm{Ky} \quad 0.3$

$-\mathrm{Kz} \quad 0.15$

-porosity $\quad 0.3$

-specific_storage 2e-008

-long_dispersivity $\quad 3.0000000 \mathrm{E}+02$

-horizontal_dispersivity 3.0000000E+01

-vertical_dispersivity 3.0000000E+01

-box -3 -3 -1450 18001800 -1000.03997802734 GRID

-description APPZ 


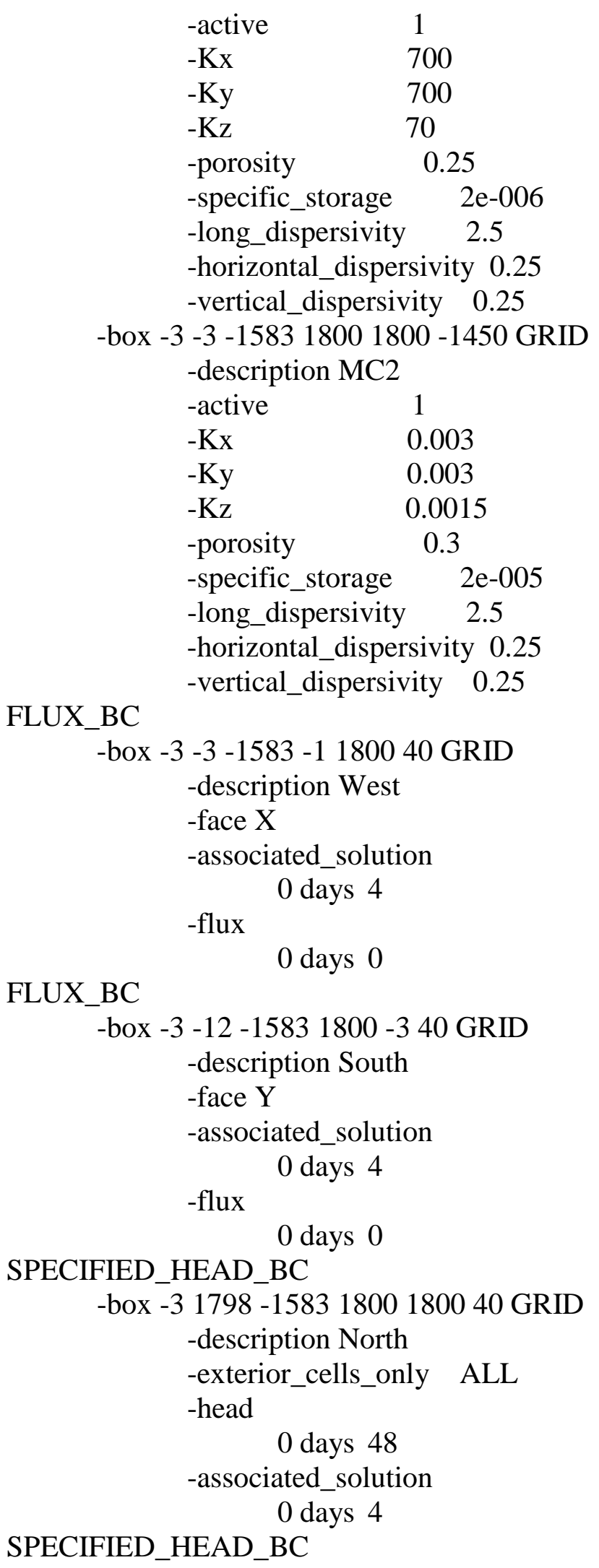


-box 3098 -3 -158318001800 40 GRID

-description East

-exterior_cells_only ALL

-head

0 days 48

-associated_solution

HEAD_IC

0 days 4

-domain

-head $\quad 48$

CHEMISTRY_IC

-domain

-solution 4

WELL 1 EXKR 1

-xy_coordinate_system GRID

-z_coordinate_system GRID

-location 00

-diameter 2

-elevation -542 -856

-allocate_by_head_and_mobility False

-injection_rate

0 days 1175000

28 days 1

56 days $\quad-1200000$

95 days 1

119 days 950000

228 days 1

289 days $\quad-1000000$

355 days 1

372 days 1250000

543 days 1

721 days $\quad-1250000$

885 days 1

909 days 1250000

1126 days 1

1460 days $\quad-1250000$

1641 days 1

-solution

0 days 2

28 days 2

95 days 2

119 days 2

228 days 2

355 days 2

372 days 2 


\begin{tabular}{lc}
\hline 443 days & 2 \\
885 days & 2 \\
909 days & 2 \\
1126 days & 2 \\
1641 days & 2
\end{tabular}

WELL 2 Observation well OKF 100U

-xy_coordinate_system GRID

-z_coordinate_system GRID

-location 13500

-diameter 1

-elevation -583 -542

-allocate_by_head_and_mobility False

-pumping_rate

$$
0 \text { days } 1
$$

PRINT_INITIAL

-boundary_conditions false

-components false

-conductances false

-echo_input false

-fluid_properties false

-force_chemistry_print false

-HDF_chemistry false

-HDF_heads false

-HDF_media false

-HDF_steady_flow_velocities false

-heads true

-media_properties false

-solution_method false

-steady_flow_velocities false

-wells false

-xyz_chemistry false

-xyz_components false

-xyz_heads false

-xyz_steady_flow_velocities false

-xyz_wells true

PRINT_FREQUENCY

-save_final_heads false

0

$$
\begin{aligned}
& \text {-bc_flow_rates } 0 \\
& \text {-boundary_conditions false } \\
& \text {-components } 0 \\
& \text {-conductances } 0 \\
& \text {-end_of_period_default false } \\
& \text {-flow_balance } 0 \\
& \text {-force_chemistry_print } 0
\end{aligned}
$$




\begin{tabular}{ccc}
-HDF_chemistry & \multicolumn{2}{c}{0} \\
-HDF_heads & 0 \\
-HDF_velocities & 0 \\
-heads & 2 & days \\
-progress_statistics & 0 \\
-restart_file & 0 & \\
-velocities & 0 & \\
-wells & 0 & \\
-xyz_chemistry & 0 \\
-xyz_components & 0 \\
-xyz_heads & 2 & days \\
-xyz_velocities & 0 \\
-xyz_wells & 1 & days \\
-zone_flow & 0 \\
-zone_flow_xyzt & 0 \\
-zone_flow_tsv & 0 \\
-hdf_intermediate & 0 \\
TIME_CONTRO & \\
-time_step & \\
0 0.2 days & \\
-time_change & \\
260 days & \\
-start_time 0 & \\
&
\end{tabular}




\section{Appendix 3 - PEST instruction file used in calibrating KRASR reactive transport model to observed heads}

Appendix 3 supports the PEST calibration input files described in section 6.5.2.1 and

Figure 6.5. PEST input files include a control file, a template file, and an instruction file.

The instruction file tells PEST where in the PHAST output a modeled concentration is

located, and which observation data point to compare it to. For example, the instruction

I25 [c2]19:30, tells PEST to advance 25 lines from the first line in the output file and

read the modeled value between columns 19 and 30, whose corresponding observed point is $c 2$ in the PEST control file. 


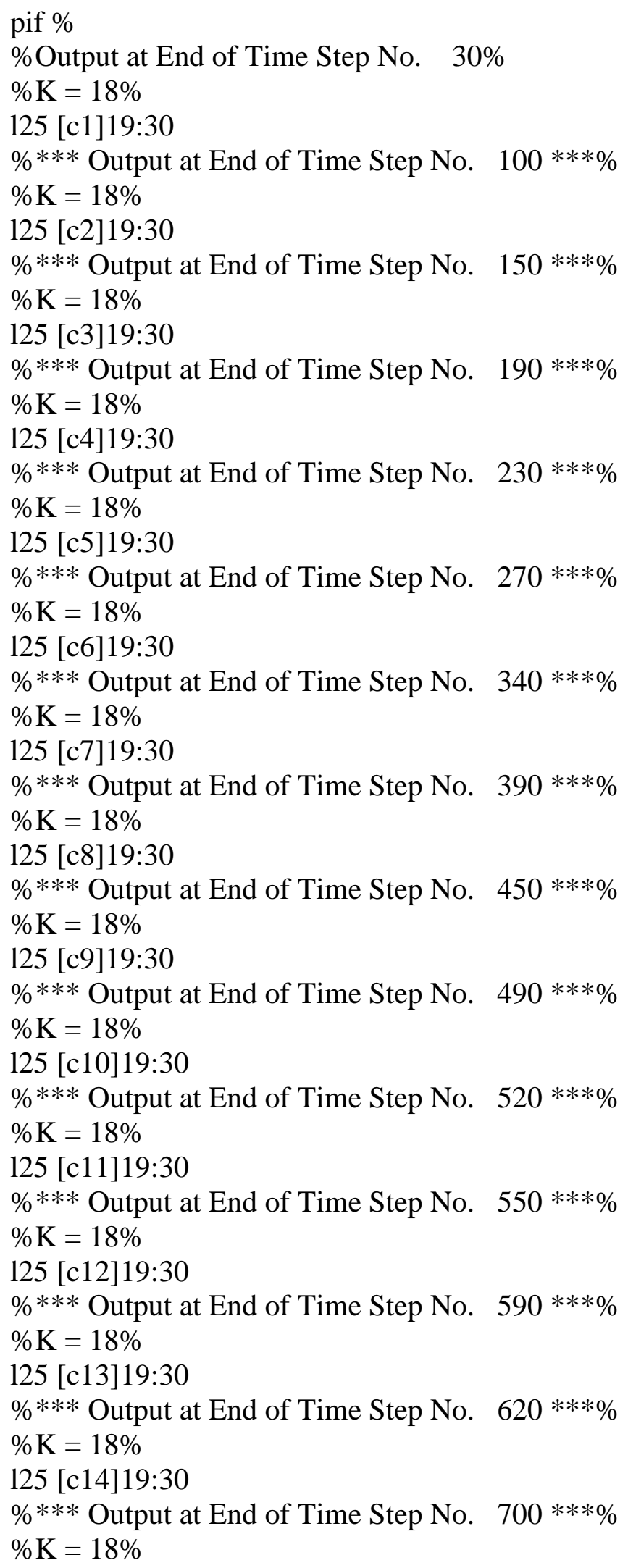


125 [c15]19:30

\%*** Output at End of Time Step No. $740 * * * \%$

$\% \mathrm{~K}=18 \%$

125 [c16]19:30

\%*** Output at End of Time Step No. $800 * * * \%$

$\% \mathrm{~K}=18 \%$

125 [c17]19:30

\%*** Output at End of Time Step No. $840 * * * \%$

$\% \mathrm{~K}=18 \%$

125 [c18]19:30

\%*** Output at End of Time Step No. $900 * * * \%$

$\% \mathrm{~K}=18 \%$

125 [c19]19:30

$\% * * *$ Output at End of Time Step No. $930 * * * \%$

$\% \mathrm{~K}=18 \%$

125 [c20]19:30

$\% * * *$ Output at End of Time Step No. $990 * * * \%$

$\% \mathrm{~K}=18 \%$

125 [c21]19:30

\%*** Output at End of Time Step No. $1040 * * * \%$

$\% \mathrm{~K}=18 \%$

125 [c22]19:30

$\% * * *$ Output at End of Time Step No. $1100 * * * \%$

$\% \mathrm{~K}=18 \%$

125 [c23]19:30

$\% * * *$ Output at End of Time Step No. $1150 * * * \%$

$\% \mathrm{~K}=18 \%$

125 [c24]19:30

\%*** Output at End of Time Step No. $1220 * * * \%$

$\% \mathrm{~K}=18 \%$

125 [c25]19:30

\%*** Output at End of Time Step No. $1270 * * * \%$

$\% \mathrm{~K}=18 \%$

125 [c26]19:30

$\% * * *$ Output at End of Time Step No. $1300 * * * \%$

$\% \mathrm{~K}=18 \%$

125 [c27]19:30 


\section{Appendix 4 - PEST control file used in calibrating KRASR reactive transport model to observed concentrations of chloride}

Appendix 4 supports the PEST calibration input files described in section 6.5.2.2 and

Figure 6.5. PEST input files include a control file, a template file, and an instruction file.

The control file defines the parameters to be estimated, optimization methods and observation data groups. 
pcf

* control data

restart estimation

1623201

11 single point 100

10.02 .00 .30 .0310

3.03 .00 .001

0.1

300.001330 .013

111

* parameter groups

d1 relative 1e-2 0.000001 switch 2 parabolic

p1 relative 1e-2 0.000001 switch 2 parabolic

* parameter data

d1 none relative $2.51100 \mathrm{~d} 11.001$

$\mathrm{d} 2$ tied relative $0.250 .110 \mathrm{~d} 11.001$

d3 tied relative $0.250 .110 \mathrm{~d} 11.001$

d4 none relative $2.51100 \mathrm{~d} 11.001$

$\mathrm{d} 5$ tied relative $0.250 .110 \mathrm{~d} 11.001$

d6 tied relative $0.250 .110 \mathrm{~d} 11.001$

d7 none relative $2.51100 \mathrm{~d} 11.001$

d8 tied relative $0.250 .110 \mathrm{~d} 11.001$

d9 tied relative $0.250 .110 \mathrm{~d} 11.001$

d10 none relative $2.51100 \mathrm{~d} 11.001$

d11 tied relative $0.250 .110 \mathrm{~d} 11.001$

d12 tied relative $0.250 .110 \mathrm{~d} 11.001$

p1 none relative 0.010 .010 .3 p1 1.001

p2 none relative 0.10 .010 .3 p1 1.001

p3 none relative 0.010 .010 .3 p1 1.001

p4 none relative 0.10 .010 .3 p1 1.001

d2 d1

d3 d1

$\mathrm{d} 5 \mathrm{~d} 4$

d6 d4

d8 d7

d9 d7

d11 d10

d12 d10

* observation groups

group_1

* observation data

c1 0.007331 group_1

c2 0.003391 group_1

c3 0.003391 group_1

c4 0.002821 group_1 


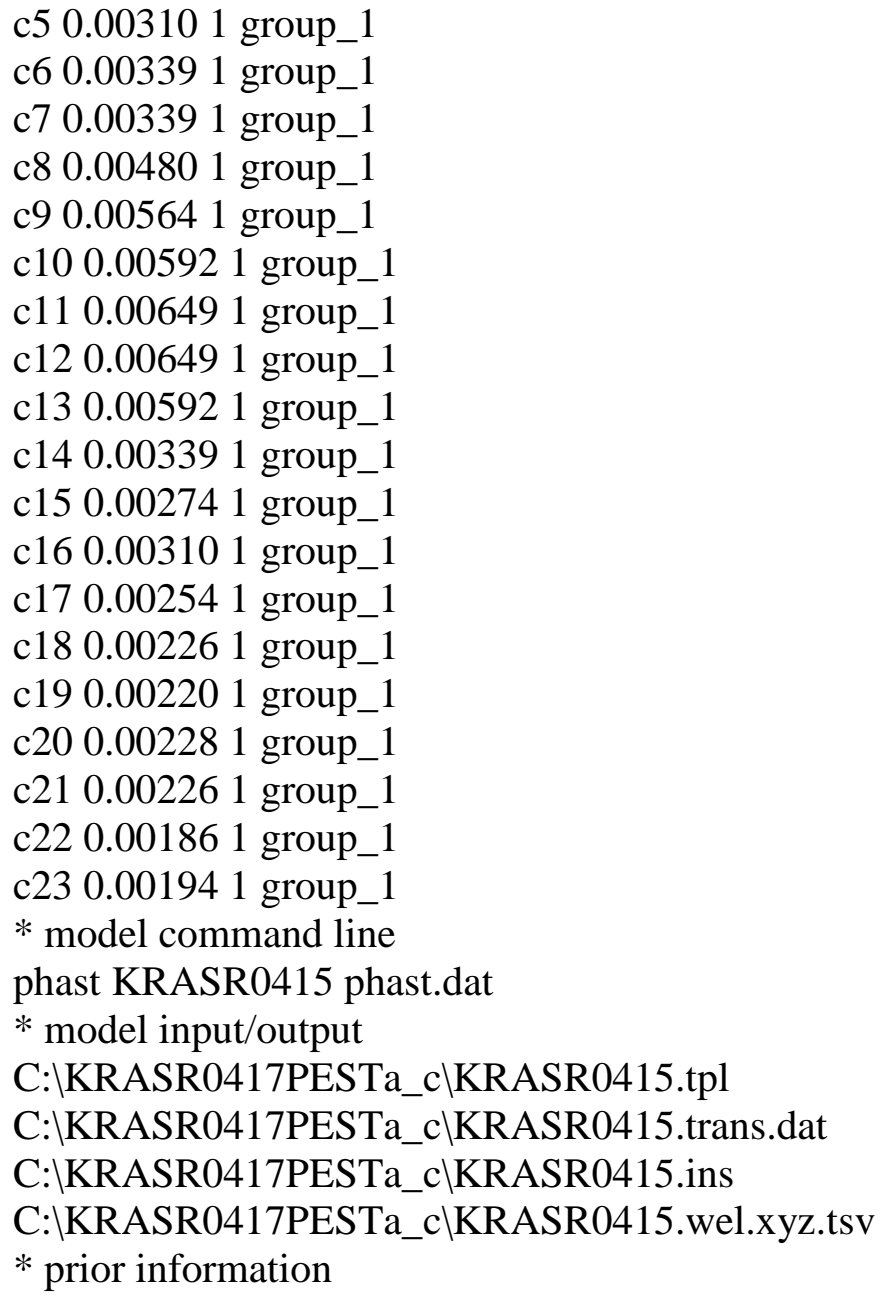




\section{Appendix 5 - PEST instruction file used in calibrating KRASR reactive transport model to observed concentrations of chloride}

Appendix 5 supports the PEST calibration input files described in section 6.5.2.2 and

Figure 6.5. PEST input files include a control file, a template file, and an instruction file.

The instruction file tells PEST where in the PHAST output a modeled concentration is

located, and which observation data point to compare it to. For example, the instruction

I25 [c2]19:30, tells PEST to advance 25 lines from the first line in the output file and

read the modeled value between columns 19 and 30, whose corresponding observed point is $c 2$ in the PEST control file. 


$$
\begin{aligned}
& \text { pif @ } \\
& 13 \text { [c1]114:127 } \\
& \text { 128 [c2]114:127 } \\
& \text { l14 [c3]114:127 } \\
& \text { l14 [c4]114:127 } \\
& 120 \text { [c5]114:127 } \\
& 110 \text { [c6]114:127 } \\
& 112 \text { [c7]114:127 } \\
& \text { l28 [c8]114:127 } \\
& \text { l14 [c9]114:127 } \\
& 114 \text { [c10]114:127 } \\
& 114 \text { [c11]114:127 } \\
& \text { 116 [c12]114:127 } \\
& 156 \text { [c13]114:127 } \\
& \text { l14 [c14]114:127 } \\
& 114 \text { [c15]114:127 } \\
& 114 \text { [c16]114:127 } \\
& 114 \text { [c17]114:127 } \\
& 114 \text { [c18]114:127 } \\
& 114 \text { [c19]114:127 } \\
& 114 \text { [c20]114:127 } \\
& 114 \text { [c21]114:127 } \\
& 114 \text { [c22]114:127 } \\
& \text { l14 [c23]114:127 }
\end{aligned}
$$


Appendix 6 - Optimization results of conservative transport at KRASR (part of the record file is shown)

Appendix 6 supports the PEST calibration output files described in section 6.5.2.2 and Figure 6.5. Part of the PEST record file is shown where summary of the optimization statistics are presented 


\section{OPTIMISATION RESULTS}

Adjustable parameters ----->

\begin{tabular}{lccc} 
Parameter & \multicolumn{2}{c}{ Estimated } & \multicolumn{2}{c}{$95 \%$ percent confidence limits } \\
& value & lower limit & upper limit \\
d1 & 1.00000 & -44.0460 & 46.0460 \\
d4 & 100.000 & -34059.1 & 34259.1 \\
d7 & 98.9647 & -4939.75 & 5137.68 \\
d10 & 1.00000 & -1655.22 & 1657.22 \\
p1 & $1.000000 \mathrm{E}-02$ & -1.63558 & 1.65558 \\
p2 & $1.000000 \mathrm{E}-02$ & -2.99955 & 3.01955 \\
p3 & $1.000000 \mathrm{E}-02$ & -0.689013 & 0.709013 \\
p4 & $1.000000 \mathrm{E}-02$ & -5.70480 & 5.72480
\end{tabular}

Note: confidence limits provide only an indication of parameter uncertainty. They rely on a linearity assumption which may not extend as far in parameter space as the confidence limits themselves - see PEST manual.

Tied parameters ----->

Parameter Estimated value

d2 $\quad 0.100000$

d3 $\quad 0.100000$

d5 $\quad 10.0000$

d6 $\quad 10.0000$

d8 $\quad 9.89647$

d9 $\quad 9.89647$ 
d11

0.100000

d12 $\quad 0.100000$

See file c: \krasr0417pesta_clkrasr0415.sen for parameter sensitivities.

Observations ------>

$\begin{array}{lrrrrr}\text { Observation } & \begin{array}{r}\text { Measured } \\ \text { value }\end{array} & \begin{array}{r}\text { Calculated } \\ \text { value }\end{array} & \text { Residual } & \text { Weight } & \text { Group } \\ \text { c1 } & \begin{array}{r}\text { 7.330000E-03 } \\ 2.421172 \mathrm{E}-04\end{array} & 7.087883 \mathrm{E}-03 & 1.000 & \text { group_1 } \\ \text { c2 } & 3.390000 \mathrm{E}-03 & 5.506009 \mathrm{E}-03 & -2.116009 \mathrm{E}-03 & 1.000 & \text { group_1 } \\ \text { c3 } & 3.390000 \mathrm{E}-03 & 4.546096 \mathrm{E}-03 & -1.156096 \mathrm{E}-03 & 1.000 & \text { group_1 } \\ \text { c4 } & 2.820000 \mathrm{E}-03 & 3.984127 \mathrm{E}-03 & -1.164127 \mathrm{E}-03 & 1.000 & \text { group_1 } \\ \text { c5 } & 3.100000 \mathrm{E}-03 & 4.004039 \mathrm{E}-03 & -9.040387 \mathrm{E}-04 & 1.000 & \text { group_1 } \\ \text { c6 } & 3.390000 \mathrm{E}-03 & 4.004006 \mathrm{E}-03 & -6.140055 \mathrm{E}-04 & 1.000 & \text { group_1 } \\ \text { c7 } & 3.390000 \mathrm{E}-03 & 4.003980 \mathrm{E}-03 & -6.139805 \mathrm{E}-04 & 1.000 & \text { group_1 } \\ \text { c8 } & 4.800000 \mathrm{E}-03 & 5.367645 \mathrm{E}-03 & -5.676448 \mathrm{E}-04 & 1.000 & \text { group_1 } \\ \text { c9 } & 5.640000 \mathrm{E}-03 & 6.102516 \mathrm{E}-03 & -4.625157 \mathrm{E}-04 & 1.000 & \text { group_1 } \\ \text { c10 } & 5.920000 \mathrm{E}-03 & 6.464927 \mathrm{E}-03 & -5.449274 \mathrm{E}-04 & 1.000 & \text { group_1 } \\ \text { c11 } & 6.490000 \mathrm{E}-03 & 6.643052 \mathrm{E}-03 & -1.530518 \mathrm{E}-04 & 1.000 & \text { group_1 } \\ \text { c12 } & 6.490000 \mathrm{E}-03 & 6.739519 \mathrm{E}-03 & -2.495185 \mathrm{E}-04 & 1.000 & \text { group_1 } \\ \text { c13 } & 5.920000 \mathrm{E}-03 & 6.734454 \mathrm{E}-03 & -8.144544 \mathrm{E}-04 & 1.000 & \text { group_1 } \\ \text { c14 } & 3.390000 \mathrm{E}-03 & 6.417082 \mathrm{E}-03 & -3.027082 \mathrm{E}-03 & 1.000 & \text { group_1 } \\ \text { c15 } & 2.740000 \mathrm{E}-03 & 5.612100 \mathrm{E}-03 & -2.872100 \mathrm{E}-03 & 1.000 & \text { group_1 } \\ \text { c16 } & 3.100000 \mathrm{E}-03 & 4.773968 \mathrm{E}-03 & -1.673968 \mathrm{E}-03 & 1.000 & \text { group_1 } \\ \text { c17 } & 2.540000 \mathrm{E}-03 & 4.187991 \mathrm{E}-03 & -1.647991 \mathrm{E}-03 & 1.000 & \text { group_1 } \\ \text { c18 } & 2.260000 \mathrm{E}-03 & 3.829862 \mathrm{E}-03 & -1.569862 \mathrm{E}-03 & 1.000 & \text { group_1 } \\ \text { c19 } & 2.200000 \mathrm{E}-03 & 3.619259 \mathrm{E}-03 & -1.419259 \mathrm{E}-03 & 1.000 & \text { group_1 } \\ \text { c20 } & 2.280000 \mathrm{E}-03 & 3.495108 \mathrm{E}-03 & -1.215108 \mathrm{E}-03 & 1.000 & \text { group_1 }\end{array}$




$\begin{array}{llllll}\text { c21 } & 2.260000 \mathrm{E}-03 & 3.420031 \mathrm{E}-03 & -1.160031 \mathrm{E}-03 & 1.000 & \text { group_1 } \\ \text { c22 } & 1.860000 \mathrm{E}-03 & 3.372629 \mathrm{E}-03 & -1.512629 \mathrm{E}-03 & 1.000 & \text { group_1 } \\ \text { c23 } & 1.940000 \mathrm{E}-03 & 3.340901 \mathrm{E}-03 & -1.400901 \mathrm{E}-03 & 1.000 & \text { group_1 }\end{array}$

See file c: \krasr0417pesta_clkrasr0415.res for more details of residuals in graph-ready format.

See file c:|krasr0417pesta_c $\backslash k r a s r 0415 . s e o$ for composite observation sensitivities.

Objective function ----->

Sum of squared weighted residuals (i.e. phi) $\quad=9.5042 \mathrm{E}-05$

Correlation Coefficient ----->

Correlation coefficient $\quad=0.7601$

Analysis of residuals ----->

All residuals:-

Number of residuals with non-zero weight $=23$

Mean value of non-zero weighted residuals $\quad=-8.5963 \mathrm{E}-04$

Maximum weighted residual [observation "c1"] $\quad=7.0879 \mathrm{E}-03$

Minimum weighted residual [observation "c14"] $\quad=-3.0271 \mathrm{E}-03$

Standard variance of weighted residuals $\quad=6.3362 \mathrm{E}-06$

Standard error of weighted residuals $\quad=2.5172 \mathrm{E}-03$

Note: the above variance was obtained by dividing the objective 
function by the number of system degrees of freedom (i.e. number of observations with non-zero weight plus number of prior information articles with non-zero weight minus the number of adjustable parameters.)

If the degrees of freedom is negative the divisor becomes

the number of observations with non-zero weight plus the number of prior information items with non-zero weight.

K-L information statistics ----->

$$
\begin{aligned}
& \mathrm{AIC}=-267.1237 \\
& \mathrm{AICC}=-253.2775 \\
& \mathrm{BIC}=-256.9042 \\
& \mathrm{KIC}=-326.8741
\end{aligned}
$$

Parameter covariance matrix ----->

$\begin{array}{lllllllllll}\mathrm{d} 1 & \mathrm{~d} 4 & \mathrm{~d} 7 & \mathrm{~d} 10 & \mathrm{p} 1 & \mathrm{p} 2 & \mathrm{p} 3 & \mathrm{p} 4 & & & \\ \mathrm{~d} 1 & 446.8 & 3.3001 \mathrm{E}+05 & -4.2878 \mathrm{E}+04 & -1.0361 \mathrm{E}+04 & -12.67 & -10.24 & 0.9043 & 12.26 \\ \mathrm{~d} 4 & 3.3001 \mathrm{E}+05 & 2.5695 \mathrm{E}+08 & -3.4389 \mathrm{E}+07 & -5.7737 \mathrm{E}+06 & -9299 . & -1.0504 \mathrm{E}+04 & 1426 . & 2898 . \\ \mathrm{d} 7 & -4.2878 \mathrm{E}+04 & -3.4389 \mathrm{E}+07 & 5.5908 \mathrm{E}+06 & 4.4400 \mathrm{E}+05 & 1273 . & 2120 . & -406.9 & 1438 . \\ \mathrm{d} 10 & -1.0361 \mathrm{E}+04 & -5.7737 \mathrm{E}+06 & 4.4400 \mathrm{E}+05 & 6.0404 \mathrm{E}+05 & 263.3 & -300.0 & 129.0 & -1578 . \\ \text { p1 } & -12.67 & -9299 . & 1273 . & 263.3 & 0.5963 & -5.0249 \mathrm{E}-02 & 2.7840 \mathrm{E}-02 & -0.6744 & \\ \text { p2 } & -10.24 & -1.0504 \mathrm{E}+04 & 2120 . & -300.0 & -5.0249 \mathrm{E}-02 & 1.995 & -0.4416 & 3.006 \\ \text { p3 } & 0.9043 & 1426 . & -406.9 & 129.0 & 2.7840 \mathrm{E}-02 & -0.4416 & 0.1076 & -0.8194 & \\ \text { p4 } & 12.26 & 2898 . & 1438 . & -1578 . & -0.6744 & 3.006 & -0.8194 & 7.192 & \end{array}$


Parameter correlation coefficient matrix ----->

$\begin{array}{llllllllll} & \mathrm{d} 1 & \mathrm{~d} 4 & \mathrm{~d} 7 & \mathrm{~d} 10 & \mathrm{p} 1 & \mathrm{p} 2 & \mathrm{p} 3 & \mathrm{p} 4 & \\ \mathrm{~d} 1 & 1.000 & 0.9739 & -0.8579 & -0.6306 & -0.7760 & -0.3430 & 0.1304 & 0.2163 \\ \mathrm{~d} 4 & 0.9739 & 1.000 & -0.9073 & -0.4634 & -0.7512 & -0.4640 & 0.2711 & 6.7424 \mathrm{E}-02 \\ \mathrm{~d} 7 & -0.8579 & -0.9073 & 1.000 & 0.2416 & 0.6972 & 0.6349 & -0.5247 & 0.2268 \\ \text { d10 } & -0.6306 & -0.4634 & 0.2416 & 1.000 & 0.4387 & -0.2733 & 0.5061 & -0.7569 \\ \text { p1 } & -0.7760 & -0.7512 & 0.6972 & 0.4387 & 1.000 & -4.6076 \mathrm{E}-02 & 0.1099 & -0.3257 \\ \text { p2 } & -0.3430 & -0.4640 & 0.6349 & -0.2733 & -4.6076 \mathrm{E}-02 & 1.000 & -0.9533 & 0.7938 \\ \text { p3 } & 0.1304 & 0.2711 & -0.5247 & 0.5061 & 0.1099 & -0.9533 & 1.000 & -0.9315 \\ \text { p4 } & 0.2163 & 6.7424 \mathrm{E}-02 & 0.2268 & -0.7569 & -0.3257 & 0.7938 & -0.9315 & 1.000\end{array}$

Normalized eigenvectors of parameter covariance matrix ----->

$\begin{array}{llllllllll} & \text { Vector_1 } & \text { Vector_2 } & \text { Vector_3 } & \text { Vector_4 } & \text { Vector_5 } & \text { Vector_6 } & \text { Vector_7 } & \text { Vector_8 } \\ \text { d1 } & -5.6596 E-03 & -1.6273 E-02 & -9.8009 E-02 & -0.1108 & 0.9888 & 6.5243 E-03 & -2.3080 E-03 & -1.2722 E-03 \\ \text { d4 } & \text { 4.6036E-06 } & 6.0785 E-05 & 1.2600 E-04 & 3.1689 E-05 & -9.9118 E-04 & -7.9073 E-02 & -0.1093 & -0.9909 \\ \text { d7 } & -9.0844 E-06 & -2.5332 E-05 & 3.3430 E-04 & -1.1507 E-03 & 9.0396 E-04 & -0.4398 & -0.8882 & 0.1331 \\ \text { d10 } & -6.9739 E-05 & -5.0693 E-04 & -1.4928 E-03 & 1.6955 E-03 & 7.0059 E-03 & -0.8946 & 0.4463 & 2.2138 E-02 \\ \text { p1 } & -4.8502 E-02 & 0.5231 & -0.8077 & -0.2484 & -9.9566 E-02 & -1.9301 E-04 & 3.0561 E-06 & 3.5878 E-05 \\ \text { p2 } & -0.1098 & 0.7583 & 0.3157 & 0.5498 & 0.1048 & 5.3343 E-04 & -7.6536 E-04 & 4.0826 E-05 \\ \text { p3 } & -0.9898 & -8.0027 E-02 & 4.3008 E-02 & -0.1091 & -1.4946 E-02 & -1.5754 E-04 & 2.3192 E-04 & -5.5936 E-06 \\ \text { p4 } & -7.7110 E-02 & -0.3803 & -0.4863 & 0.7822 & 3.2746 E-02 & 1.7613 E-03 & -2.0253 E-03 & -1.0376 E-05\end{array}$

Eigenvalues ----->

3.6426E-05 6.2051E-03 8.1691E-02 $2.478 \quad 4.020 \quad 3.1207 \mathrm{E}+05 \quad 1.1347 \mathrm{E}+06 \quad 2.6170 \mathrm{E}+08$


Appendix 7 - Chemistry file used in PHAST to simulate fate and transport of reactive constituents at KRASR

Appendix 7 supports the PHAST input files described in section 6.6 and Figure 6.5. Chemistry file is a PHREEQC input file where the solution species, phases and reactions are defined. 
database C:/wateq4f.dat

SOLUTION_MASTER_SPECIES

Dom Dom 01212

Fe_di Fe_di+2 $\quad 0.0 \quad 55.84755 .847$

Fe_tri Fe_tri+3 $\quad-2.0 \quad 55.84755 .847$

SOLUTION_SPECIES

$\mathrm{H} 2 \mathrm{O}+0.01 \mathrm{e}-=\mathrm{H} 2 \mathrm{O}-0.01$

log_k -9

Dom $=$ Dom

log_k 0

delta_h $0 \mathrm{~kJ}$

Fe_di $+2=$ Fe_di +2

log_k 0.0

Fe_tri+3 = Fe_tri+3

log_k 0

Fe_tri+3 + H2O = Fe_triOH+2 $+\mathrm{H}+$

log_k $\quad-2.19$

delta_h 10.4 kcal

$\mathrm{Fe} \_\mathrm{di}+2+\mathrm{H} 2 \mathrm{O}=\mathrm{Fe} \_\mathrm{diOH}++\mathrm{H}+$

log_k $\quad-9.5$

delta_h $13.2 \mathrm{kcal}$

$\mathrm{Fe} \_\mathrm{di}+2+3 \mathrm{H} 2 \mathrm{O}=\mathrm{Fe} \_$di $(\mathrm{OH}) 3-+3 \mathrm{H}+$

log_k $\quad-31.0$

delta_h $30.3 \mathrm{kcal}$

Fe_tri+3 + SO4-2 = Fe_triSO4+

log_k 4.04

delta_h 3.91 kcal

$\mathrm{Fe} \_$tri $+3+\mathrm{Cl}-=\mathrm{Fe} \_$triCl+2

log_k $\quad 1.48$

delta_h 5.6 kcal

Fe_tri+3 + 2Cl- = Fe_triCl2+

log_k 2.13

Fe_tri+3 $+3 \mathrm{Cl}-=\mathrm{Fe} \_$triCl3

log_k 1.13

$\mathrm{Fe} \_$di $+2+\mathrm{SO} 4-2=\mathrm{Fe} \_$diSO4

log_k 2.25

delta_h 3.23 kcal

$\mathrm{Fe} \_$tri $+3+2 \mathrm{H} 2 \mathrm{O}=\mathrm{Fe} \_$tri $(\mathrm{OH}) 2++2 \mathrm{H}+$

log_k $\quad-5.67$

delta_h $17.1 \mathrm{kcal}$

Fe_tri+3 + 3H2O = Fe_tri(OH)3 $+3 \mathrm{H}+$ 
log_k $\quad-12.56$

delta_h $24.8 \mathrm{kcal}$

$\mathrm{Fe} \_$tri $+3+4 \mathrm{H} 2 \mathrm{O}=\mathrm{Fe} \_$tri $(\mathrm{OH}) 4-+4 \mathrm{H}+$

log_k $\quad-21.6$

delta_h $31.9 \mathrm{kcal}$

$\mathrm{Fe} \_$di $+2+2 \mathrm{H} 2 \mathrm{O}=\mathrm{Fe} \_$di $(\mathrm{OH}) 2+2 \mathrm{H}+$

log_k $\quad-20.57$

delta_h 28.565 kcal

Fe_di+2 + H2PO4- = Fe_diH2PO4+

log_k 2.7

Fe_di+2 + HPO4-2 = Fe_diHPO4

log_k 3.6

Fe_tri+3 + HPO4-2 = Fe_triHPO4+

log_k $\quad 5.43$

delta_h 5.76 kcal

Fe_di+2 + HSO4- = Fe_diHSO4+

log_k $\quad 1.08$

Fe_tri+3 + H2PO4- = Fe_triH2PO4+2

log_k $\quad 5.43$

Fe_tri+3 + HSO4- = Fe_triHSO4+2

log_k 2.48

Fe_tri+3 + F- = Fe_triF+2

log_k 6.2

delta_h 2.7 kcal

Fe_tri+3 + 2F- = Fe_triF2+

$\log \mathrm{k} \quad 10.8$

delta_h $4.8 \mathrm{kcal}$

Fe_tri+3 + 3F- $=$ Fe_triF3

log_k 14.0

delta_h 5.4 kcal

Fe_tri+3 + 2SO4-2 = Fe_tri(SO4)2-

log_k 5.38

delta_h $4.6 \mathrm{kcal}$

$2 \mathrm{Fe} \_$tri $+3+2 \mathrm{H} 2 \mathrm{O}=\mathrm{Fe} \_$tri2 $(\mathrm{OH}) 2+4+2 \mathrm{H}+$

log_k $\quad-2.95$

delta_h $13.5 \mathrm{kcal}$

$3 \mathrm{Fe} \_$tri $+3+4 \mathrm{H} 2 \mathrm{O}=\mathrm{Fe} \_$tri3 $(\mathrm{OH}) 4+5+4 \mathrm{H}+$

log_k $\quad-6.3$

delta_h $14.3 \mathrm{kcal}$

$\mathrm{Fe} \_\mathrm{di}+2+\mathrm{F}-=\mathrm{Fe} \_\mathrm{diF}+$

log_k $\quad 1.0$

Fe_di+2 + 2HS- = Fe_di(HS)2

log_k 8.95

Fe_di+2 + 3HS- = Fe_di(HS)3-

log_k 10.987 
Fe_tri+3 + Fulvate- $2=$ Fe_triFulvate +

log_k 9.4

Fe_tri+3 + Humate-2 $=$ Fe_triHumate +

log_k 9.4

Fe_di+2 + Cl- = Fe_diCl+

log_k 0.14

Fe_di+2 + HCO3- = Fe_diHCO3+

log_k 2.0

$\mathrm{Fe} \_$di $+2+\mathrm{CO} 3-2$ = Fe_diCO3

log_k 4.38

\section{PHASES}

Siderite(d)(3) 9

$\mathrm{Fe} \_$diCO3 $=\mathrm{Fe} \_\mathrm{di}+2+\mathrm{CO} 3-2$

log_k $\quad-10.45$

Mackinawite 67

Fe_diS $+\mathrm{H}+=$ Fe_di +2 + HS-

log_k $\quad-4.648$

Siderite $\quad 94$

$\mathrm{Fe} \_$diCO3 $=\mathrm{Fe} \_$di $+2+\mathrm{CO} 3-2$

log_k $\quad-10.89$

delta_h $-2.48 \mathrm{kcal}$

Magnetite $\quad 107$

Fe_diFe_tri2O $4+8 \mathrm{H}+=2 \mathrm{Fe} \_t r i+3+\mathrm{Fe} \_d i+2+4 \mathrm{H} 2 \mathrm{O}$

log_k $\quad 3.737$

delta_h $-50.460 \mathrm{kcal}$

Hematite $\quad 108$

Fe_tri2O3 $+6 \mathrm{H}+=2 \mathrm{Fe} \_$tri $+3+3 \mathrm{H} 2 \mathrm{O}$

log_k $\quad-4.008$

delta_h $-30.845 \mathrm{kcal}$

Maghemite 109

$\mathrm{Fe} \_$tri2 $\mathrm{O} 3+6 \mathrm{H}+=2 \mathrm{Fe} \_$tri $+3+3 \mathrm{H} 2 \mathrm{O}$

log_k 6.386

Goethite $\quad 110$

Fe_triOOH $+3 \mathrm{H}+=$ Fe_tri+3 $+2 \mathrm{H} 2 \mathrm{O}$

log_k $\quad-1.0$

delta_h $-14.48 \mathrm{kcal}$

Greenalite

111

Fe_di3Si2O5(OH)4 + 6H+ = 3Fe_di+2 + 2 H4SiO4 + H2O

log_k 20.810

Annite 113

$\mathrm{KFe} \_$di3AlSi3O10 $(\mathrm{OH}) 2+10 \mathrm{H} 2 \mathrm{O}=\mathrm{K}++3 \mathrm{Fe} \_\mathrm{di}+2+\mathrm{Al}(\mathrm{OH}) 4-+3 \mathrm{H} 4 \mathrm{SiO} 4$

$+6 \mathrm{OH}-$

log_k $\quad-85.645$ 
delta_h $62.480 \mathrm{kcal}$

Greigite $\quad 118$

Fe_diFe_tri2S4 $+4 \mathrm{H}+=2 \mathrm{Fe} \_$tri $+3+\mathrm{Fe} \_$di $+2+4 \mathrm{HS}-$

log_k -45.035

Fe_diS(ppt) 119

Fe_diS + H+ = Fe_di+2 + HS-

$\log k \quad-3.915$

Strengite $\quad 146$

Fe_triPO4:2H2O = Fe_tri+3 + PO4-3 + 2H2O

log_k $\quad-26.4$

delta_h -2.030 kcal

Fe_tri(OH)2.7Cl.3 181

Fe_tri $(\mathrm{OH}) 2.7 \mathrm{Cl} 0.3+2.7 \mathrm{H}+=\mathrm{Fe}_{-}$tri $+3+2.7 \mathrm{H} 2 \mathrm{O}+0.3 \mathrm{Cl}-$

log_k $\quad-3.040$

CupricFerrite 249

CuFe_tri2O $4+8 \mathrm{H}+=\mathrm{Cu}+2+2 \mathrm{Fe} \_$tri $+3+4 \mathrm{H} 2 \mathrm{O}$

$\log _{\mathrm{k}} \mathrm{k} \quad 5.880$

delta_h $-38.690 \mathrm{kcal}$

Chalcopyrite 250

CuFe_diS2 + 2H+ = Cu+2 + Fe_di+2 + 2HS-

log_k $\quad-35.270$

delta_h 35.480 kcal

Melanterite 339

Fe_diSO4:7H2O = Fe_di $+2+\mathrm{SO} 4-2+7 \mathrm{H} 2 \mathrm{O}$

log_k $\quad-2.209$

delta_h 4.91 kcal

$\begin{array}{llllll}\text { analytical_expression } & 1.447 & -0.004153 & 0.0 & 0.0 & -214949.0\end{array}$

Fe_diFe_tri2 $(\mathrm{OH}) 8$ 419

Fe_diFe_tri2 $(\mathrm{OH}) 8+8 \mathrm{H}+=2 \mathrm{Fe} \_t r i+3+\mathrm{Fe} \_d i+2+8 \mathrm{H} 2 \mathrm{O}$

log_k 20.222

Scorodite 492

Fe_triAsO4:2H2O = Fe_tri+3 + AsO4-3 + 2H2O

log_k $\quad-20.249$

Fe_diSe2 552

Fe_diSe2 $+2 \mathrm{H}++2 \mathrm{e}-=\mathrm{Fe} \_\mathrm{di}+2+2 \mathrm{HSe}-$

log_k $\quad-18.580$

Bassetite $\quad 628$

$\mathrm{Fe} \_$di $(\mathrm{UO} 2) 2(\mathrm{PO} 4) 2=\mathrm{Fe} \_\mathrm{di}+2+2 \mathrm{UO} 2+2+2 \mathrm{PO} 4-3$

log_k $\quad-44.485$

delta_h -19.9 kcal

As-pyrite

Fe_diAs0.01S1.99 + 1.96H + + 0.03H2O + 1.95e- $=$ Fe_di $+2+$ $0.01 \mathrm{H} 3 \mathrm{AsO}+1.99 \mathrm{HS}-$

log_k -18.479 


\section{delta_h $11.3 \mathrm{kcal}$}

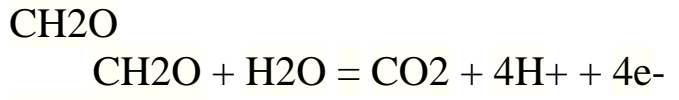

Ferrihydrite

Fe_tri $(\mathrm{OH}) 3+3 \mathrm{H}+=$ Fe_tri+3 $+3 \mathrm{H} 2 \mathrm{O}$

log_k 3.191

delta_h $-73.374 \mathrm{~kJ}$

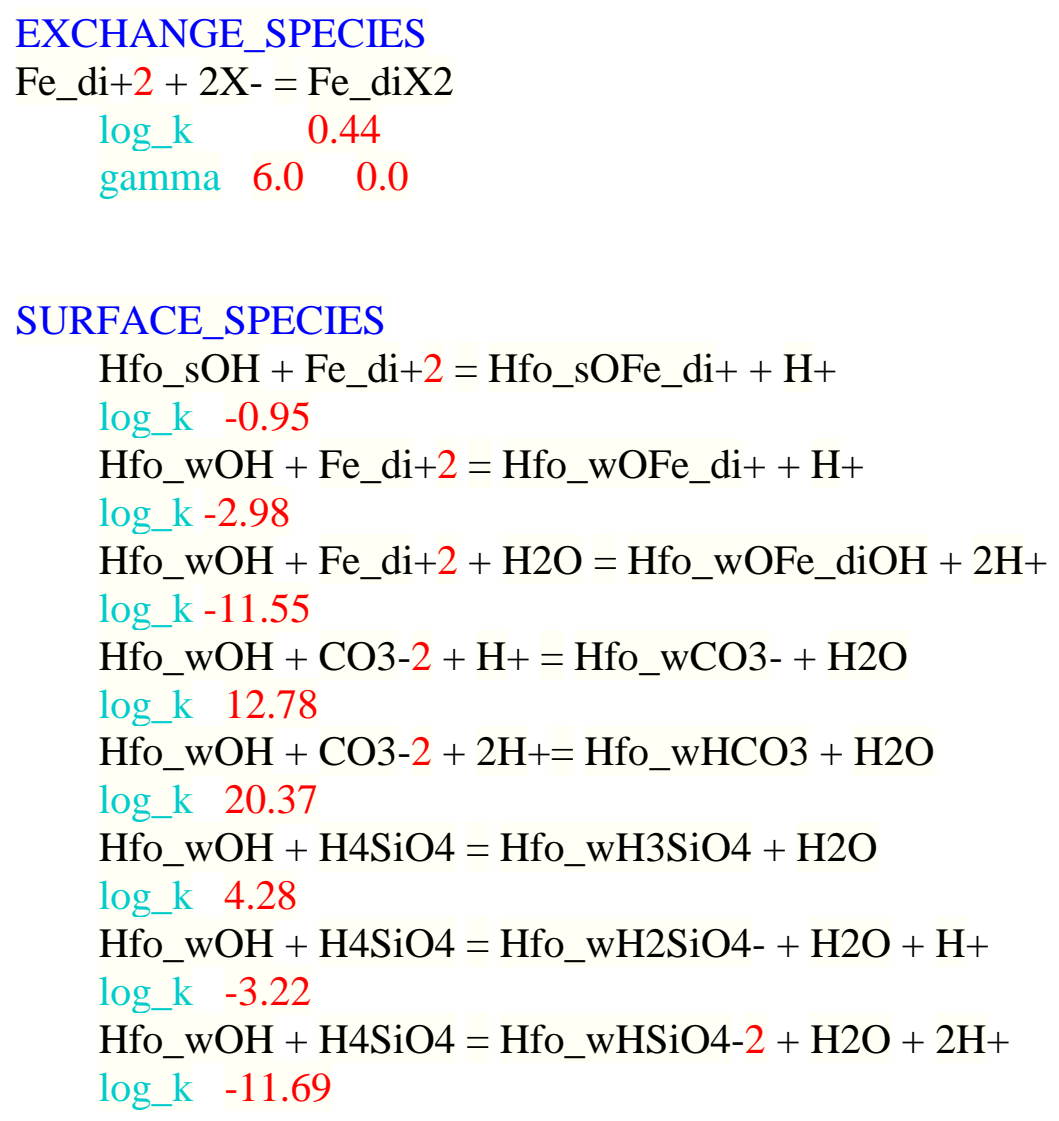

EQUILIBRIUM_PHASES 4

Ferrihydrite 00

Siderite 00

Calcite 0

SOLUTION 4 \#Native water at ASR well

units $\mathrm{mg} / \mathrm{L}$

temp 25.5

$\mathrm{pH} \quad 7.8$ 


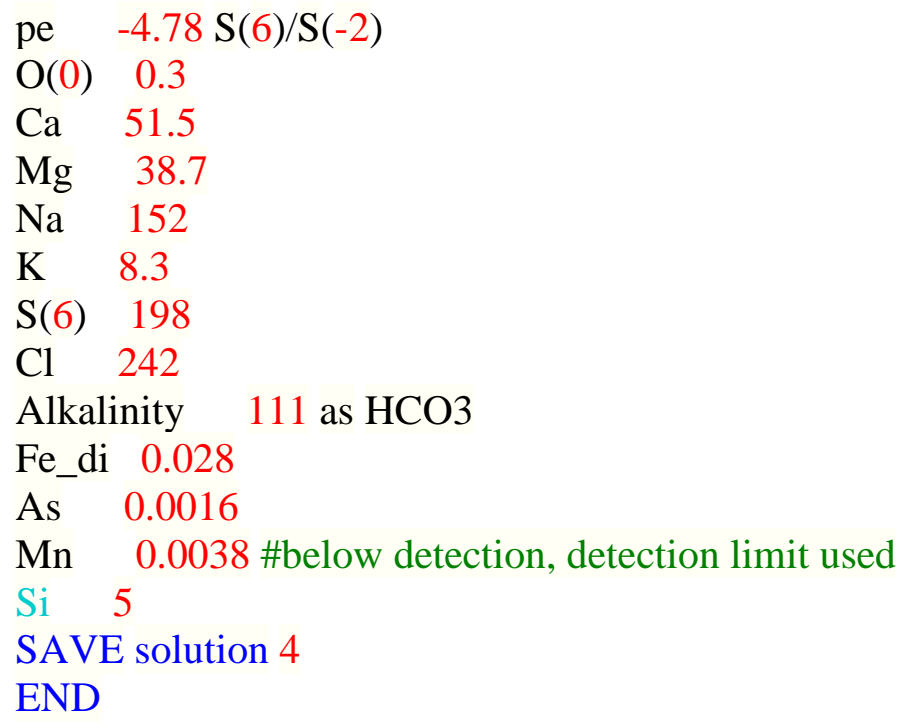

EXCHANGE 4

$\mathrm{X} 0.00015$

equilibrate 4

equilibrate 4

END

SURFACE 4

Hfo_wOH Ferrihydrite equilibrium_phase .2 5.33e4

Hfo_sOH Ferrihydrite equilibrium_phase .005

equilibrate 4

END

\section{RATES}

As-pyrite \# Williamson and Rimstidt, 1994

start

10 if $(\mathrm{m}<=0$ ) then goto 200

20 if (si("As-pyrite") >= 0) then goto 100

25 rate10 $=-10.19+$ parm $(1)+0.67 * \log 10(\mathrm{~m} / \mathrm{m} 0)+0.5 * \operatorname{lm}(" \mathrm{O} 2 ")+(-$ $0.11) * \operatorname{lm}(" \mathrm{H}+")$

30 rate $1=10^{\wedge}$ rate 10

33 rate $=$ rate $1 *(1-$ SR $(" A s-p y r i t e "))$

35 moles $=$ rate $*$ time

37 put(rate,1)

40 if (moles $>\mathrm{m}$ ) then moles $=\mathrm{m}$

100 save moles 
end

Organic_C \# Van Cappellen \& Gaillard, 1996

start

10 if $(\mathrm{m}<=0)$ then goto 100

$20 \mathrm{mO} 2=\operatorname{mol}(" \mathrm{O} 2 ")$

30 rate $=m *(\mathrm{~m} / \mathrm{m0}) * \operatorname{parm}(1) * \mathrm{mO} 2 /(\operatorname{parm}(2)+\mathrm{mO} 2)$

40 moles $=$ rate $*$ time

50 put(rate,2)

60 if $($ moles $>m$ ) then moles $=m$

100 save moles

end

Fe_di_ox_hom \# Singer \& Stumm, 1970

start

10 Fe_di = MOL("Fe_di+2")

20 if (Fe_di $<=0)$ then goto 100

30 p_o2 = 10^(SI("O2(g)"))

40 rate $=$ parm $(1) *($ ACT $(" O H-")) \wedge 2 *$ p_o2 $*$ Fe_di

50 moles $=$ rate $^{*}$ time

60 put(rate,3)

70 if (moles $>$ Fe_di) then moles $=$ Fe_di

100 save moles

end

Fe_di_ox_hfo \# Tamura, 1976

start

10 Fe_di $=$ MOL("Fe_di+2")

20 if $\left(F e \_d i<=0\right)$ then goto 100

30 p_o2 = 10^(SI("O2(g)"))

40 Fe_di_ads = MOL("Hfo_sOFe_di+") + MOL("Hfo_wOFe_di+")

50 rate $=$ parm $(1) *$ Fe_di_ads $*$ MOL("O2")

60 moles $=$ rate $*$ time

70 put(rate,4)

80 if (moles $>$ Fe_di_ads) then moles $=$ Fe_di_ads

100 save moles

end

React_DOM

start

$10 \mathrm{k}=0.1 /(3600 * 24) \# 0.1$ per day

20 rate $=\mathrm{k} *$ TOT("Dom")

30 moles $=$ rate $*$ TIME

40 put(rate,8)

50 SAVE moles

End

KINETICS 4 


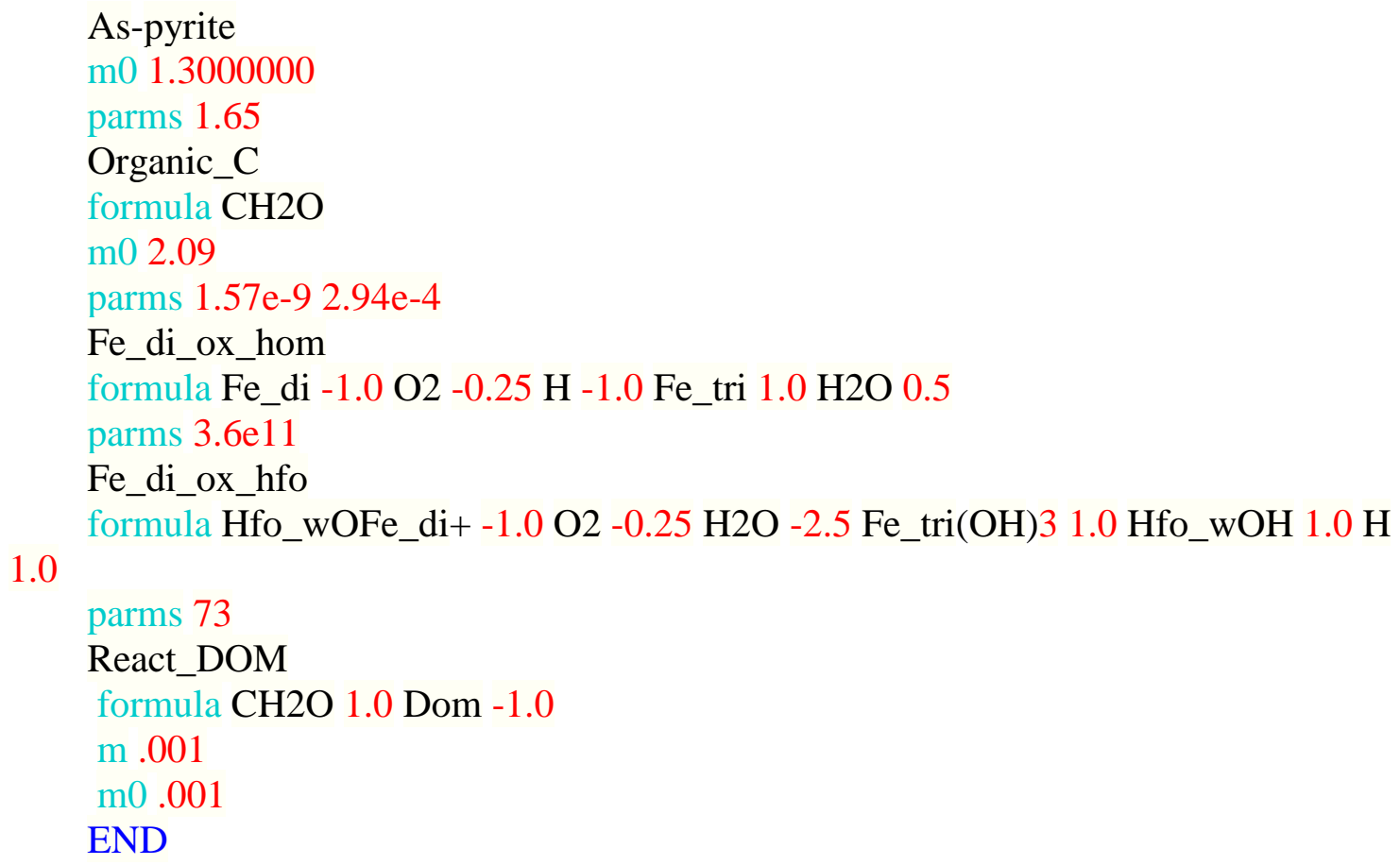


reset false

ph

pe

USER_PUNCH

heading $\mathrm{Ca} \mathrm{Cl}$ As Fe_di Fe_tri DO Sulfate K Mg Na HCO3

10 PUNCH TOT("Ca")*1e3*40.08

20 PUNCH TOT("Cl")*1e3*35.45

30 PUNCH TOT("As")*74.92*1000

40 PUNCH TOT("Fe_di")*55.85*1e6

50 PUNCH TOT("Fe_tri")*55.85*1e6

60 PUNCH TOT("O(0)")*32*1000

70 PUNCH TOT("S(6)")*96*1000

80 PUNCH TOT("K")*39.102*1000

90 PUNCH TOT("Mg")*24.312*1000

100 PUNCH TOT("Na")*22.99*1000

110 PUNCH TOT("Alkalinity")*61*1000

END 


\section{Appendix 8 - FloPy's MODFLOW model and package classes}

Appendix 8 supports section 7.4.1 and summarizes package classes that can be defined for a FloPy simulation. 


\begin{tabular}{|c|c|c|}
\hline Model Classes & Package Classes & Package Description \\
\hline flopy.modflow.mf.Modflow( ) & $\begin{array}{l}\text { flopy.modflow.mfbas.ModflowBas } \\
\text { flopy.modflow.mfbcf.ModflowBcf } \\
\text { flopy.modflow.mfchd.ModflowChd } \\
\text { flopy.modflow.mfde4.ModflowDe4 } \\
\text { flopy.modflow.mfdis.ModflowDis } \\
\text { flopy.modflow.mfdrn.ModflowDrn } \\
\text { flopy.modflow.mfevt.ModflowEvt } \\
\text { flopy.modflow.mfghb.ModflowGhb } \\
\text { flopy.modflow.mfgmg.ModflowGmg } \\
\text { flopy.modflow.mflmt.ModflowLmt } \\
\text { flopy.modflow.mflpf.ModflowLpf } \\
\text { flopy.modflow.mfmnw1.ModflowMnw1 } \\
\text { flopy.modflow.mfmnw2.ModflowMnw2 } \\
\text { flopy.modflow.mfmnwi.ModflowMnwi } \\
\text { flopy.modflow.mfnwt.ModflowNwt } \\
\text { flopy.modflow.mfoc.ModflowOc } \\
\text { flopy.modflow.mfpbc.ModflowPbc } \\
\text { flopy.modflow.mfpcg.ModflowPcg } \\
\text { flopy.modflow.mfpcgn.ModflowPcgn } \\
\text { flopy.modflow.mfrch.ModflowRch } \\
\text { flopy.modflow.mfriv.ModflowRiv } \\
\text { flopy.modflow.mfsip.ModflowSip } \\
\text { flopy.modflow.mfsms.ModflowSms } \\
\text { flopy.modflow.mfsor.ModflowSor } \\
\text { flopy.modflow.mfswi.ModflowSwi }\end{array}$ & $\begin{array}{l}\text { Basic Package } \\
\text { Block Centered Flow package } \\
\text { Constant Head package } \\
\text { DE4 - Direct Solver Package } \\
\text { Discretization Package } \\
\text { Drain Package } \\
\text { Evapotranspiration } \\
\text { General-Head Boundary Package } \\
\text { GMG package } \\
\text { MT3D link package } \\
\text { Discretization Package } \\
\text { Multi-node well 1 package } \\
\text { Multi-node well 2 package } \\
\text { Multi-node well info. package } \\
\text { Newton solver package } \\
\text { Output Control option } \\
\text { Periodic boundary condition } \\
\text { PCG solver } \\
\text { PCGN solver } \\
\text { Recharge Package } \\
\text { River Package } \\
\text { Strongly Implicit Procedure } \\
\text { package } \\
\text { Solver for MODFLOW-USG } \\
\text { Slice-successive over-relaxation } \\
\text { package } \\
\text { Salt Water Intrusion (SWI) } \\
\text { package }\end{array}$ \\
\hline
\end{tabular}




\begin{tabular}{|c|c|c|}
\hline Model Classes & Package Classes & Package Description \\
\hline & flopy.modflow.mfswi2.ModflowSwi2 & $\begin{array}{l}\text { Salt Water Intrusion (SWI2) } \\
\text { package }\end{array}$ \\
\hline & flopy.modflow.mfupw.ModflowUpw & Upstream weighting package \\
\hline & $\begin{array}{l}\text { flopy.modflow.mfuzf1.ModflowUzf1 } \\
\text { flopy.modflow.mfwel.ModflowWel }\end{array}$ & $\begin{array}{l}\text { UZF1 } \\
\text { Well Package }\end{array}$ \\
\hline flopy.modpath.mp.Modpath & $\begin{array}{l}\text { flopy.modpath.mpbas.ModpathBas } \\
\text { flopy.modpath.mpsim.ModpathSim }\end{array}$ & $\begin{array}{l}\text { Basic Package Class } \\
\text { Simulation File Package }\end{array}$ \\
\hline flopy.mt3dms.mt.Mt3dList & $\begin{array}{l}\text { flopy.mt3dms.mtadv.Mt3dAdv } \\
\text { flopy.mt3dms.mtbtn.Mt3dBtn } \\
\text { flopy.mt3dms.mtdsp.Mt3dDsp } \\
\text { flopy.mt3dms.mtgcg.Mt3dGcg } \\
\\
\text { flopy.mt3dms.mtphc.Mt3dPhc } \\
\text { flopy.mt3dms.mtrct.Mt3dRct } \\
\text { flopy.mt3dms.mtssm.Mt3dSsm } \\
\text { flopy.mt3dms.mttob.Mt3dTob }\end{array}$ & $\begin{array}{l}\text { Advection package } \\
\text { Basic transport package } \\
\text { Dispersion package } \\
\text { Generalized Conjugate Gradient } \\
\text { solver } \\
\text { PHC package class for PHT3D } \\
\text { Chemical reaction package } \\
\text { Sink \& Source Mixing package } \\
\text { Transport Observation package }\end{array}$ \\
\hline \multirow[t]{2}{*}{ flopy.seawat.swt.Seawat } & flopy.seawat.swtvdf.SeawatVdf & Variable density flow package \\
\hline & $\begin{array}{l}\text { flopy.utils.binaryfile.BinaryLayerFile } \\
\text { flopy.utils.mtreadbinaries.Mt3dPsRead } \\
\text { flopy.utils.mfreadbinaries.BinaryReader } \\
\text { flopy.utils.util_array.array2string }\end{array}$ & $\begin{array}{l}\text { The BinaryLayerFile class is the } \\
\text { super class from which specific } \\
\text { derived classes are formed } \\
\text { Reads binary output from } \\
\text { MT3DMS models } \\
\text { Generic class for reading binary } \\
\text { output from } \\
\text { MODFLOW/MT3DMS models } \\
\text { Converts a 1D or 2D array into a } \\
\text { string Input }\end{array}$ \\
\hline
\end{tabular}


Appendix 9 - List of operators implemented in DEAP for evolutionary algorithms. The operators are contained in the tools module of DEAP

Appendix 9 supports section 7.4.2 and summarizes common tools and operators that can be implemented for evolutionary algorithms in DEAP. 


\begin{tabular}{|l|l|l|l|}
\hline Initialization & Crossover & Mutation & Selection \\
\hline initRepeat( ) & cxOnePoint( ) & mutGaussian( ) & selTournament( ) \\
\hline initIterate( ) & cxTwoPoint( ) & mutShuffleIndexes( ) & selRoulette( ) \\
\hline initCycle( ) & cxUniform( ) & mutFlipBit( ) & selNSGA2( ) \\
\hline & cxPartialyMatched( ) & mutPolynomialBounded( ) & selSPEA2( ) \\
\hline & cxUniformPartialyMatched( ) & mutUniformInt( ) & selRandom( ) \\
\hline & cxOrdered( ) & mutESLogNormal( ) & selBest( ) \\
\hline & cxBlend( ) & & selWorst( ) \\
\hline & cxESBlend( ) & & selTournamentDCD( ) \\
\hline & cxESTwoPoint( ) & \\
\hline & cxSimulatedBinary( ) & & \\
\hline & cxSimulatedBinaryBounded( ) & & \\
\hline & cxMessyOnePournament( ) \\
\hline & & & \\
\hline
\end{tabular}


Appendix 10 - Python code used in multi-objective simulation-optimization of salt water management for the Biscayne Aquifer:

Appendix 10 supports multi-objective optimization in chapter 7. The management model is applied to a cross-section of the Biscayne Aquifer in Coconut Grove, Miami. Code is shown for the abstraction-desalination-recharge scenario 
1. \# DEAP is free software: you can redistribute it and/or modify

2. \# it under the terms of the GNU Lesser General Public License as

3. \# published by the Free Software Foundation, either version 3 of

4. \# the License, or (at your option) any later version.

5. \#

6. \# DEAP is distributed in the hope that it will be useful,

7. \# but WITHOUT ANY WARRANTY; without even the implied warranty of

8. \# MERCHANTABILITY or FITNESS FOR A PARTICULAR PURPOSE.

9. \# See the GNU Lesser General Public License for more details.

10. \#

11. \# You should have received a copy of the GNU Lesser General Public

12. \# License along with DEAP. If not, see <http://www.gnu.org/licenses/>.

13. \%matplotlib inline

14. import os

15. import numpy as np

16. import flopy

17. import array

18. import random

19. import json

20. import fortin 2013

21. from math import sqrt

22. from deap import algorithms

23. from deap import base

24. from deap import benchmarks

25. from deap.benchmarks.tools import diversity, convergence

26. from deap import creator

27. from deap import tools

28. import matplotlib.pyplot as plt

29. import matplotlib.cm as $\mathrm{cm}$ \#color ramp

30. import flopy.utils.binaryfile as bf

31. import csv

32. $\mathrm{Lx}=6000$

33. $\mathrm{Lz}=40$

34. nlay $=20$

35. nrow $=1$

36. $\mathrm{ncol}=30$

37. delr $=\mathrm{Lx} /$ ncol

38. delc $=1$.

39. delv = Lz / nlay

40. henry_top $=40$.

41. henry_botm $=$ np.linspace $($ henry_top - delv, 0 ., nlay)

42. qinflow $=15$. $\# \mathrm{~m} 3 /$ day per $\mathrm{m}$ width

43. dmcoef $=0 \#$ molecular diffusion, $\mathrm{m} 2$ /day 


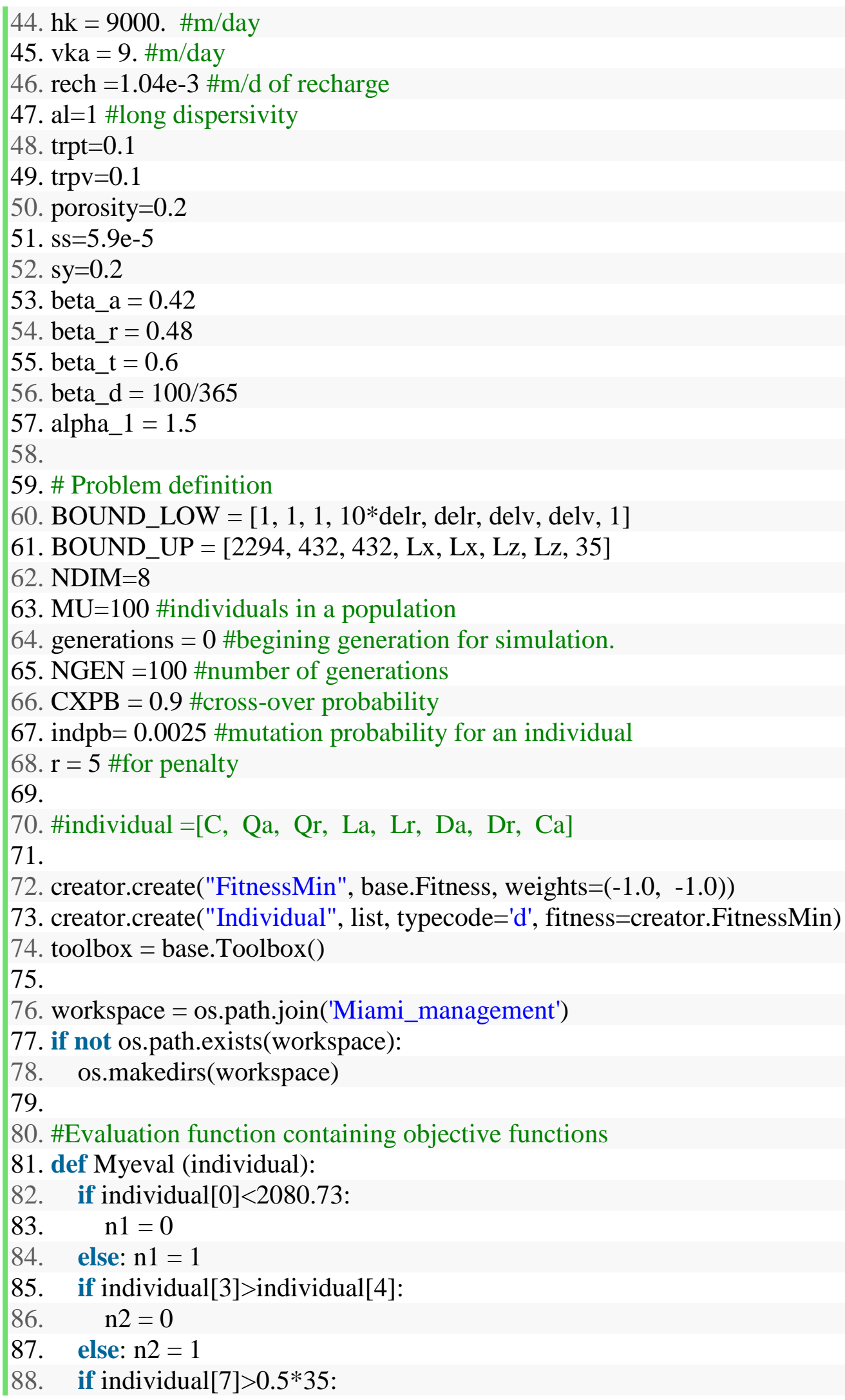




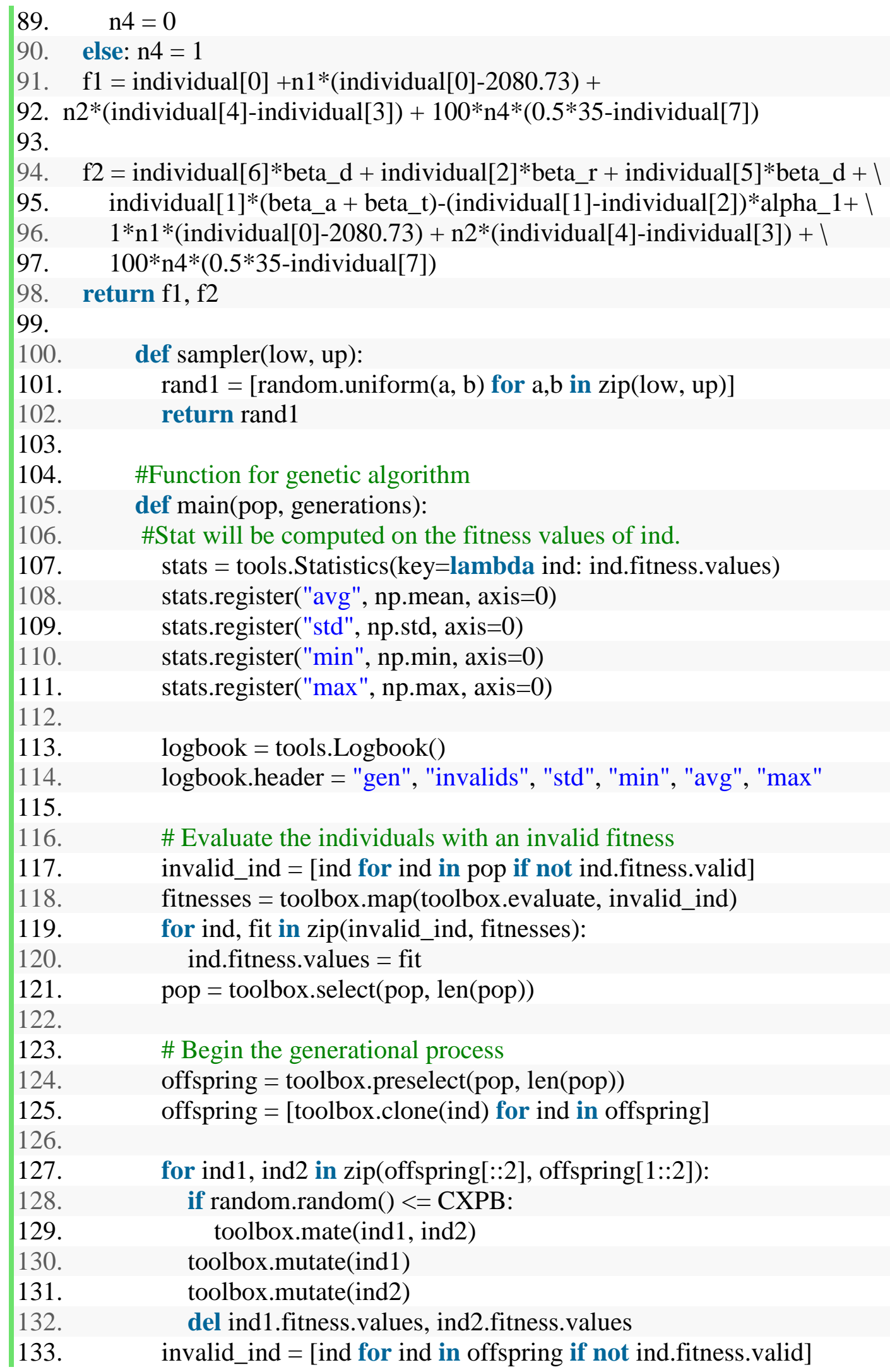




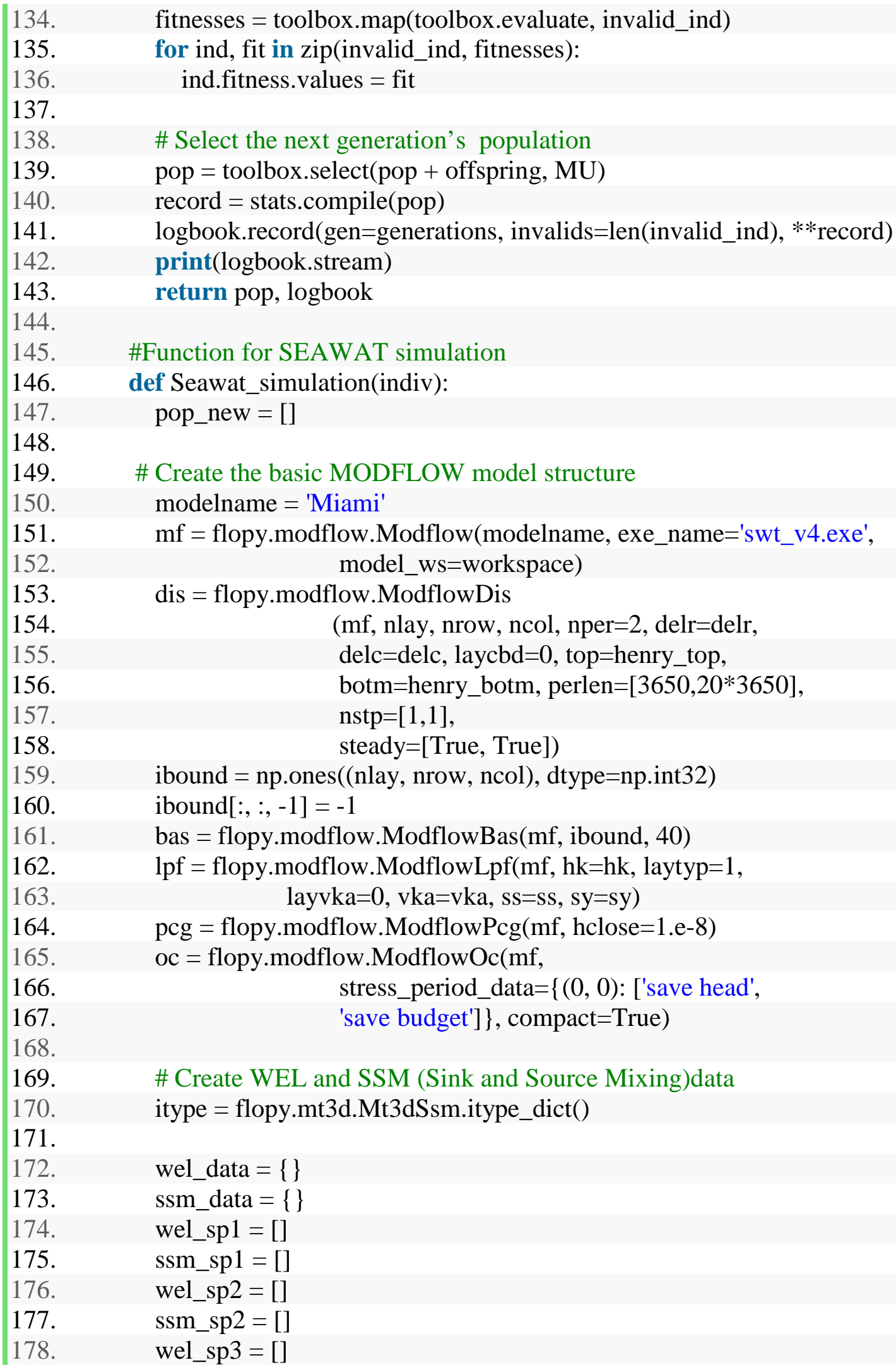




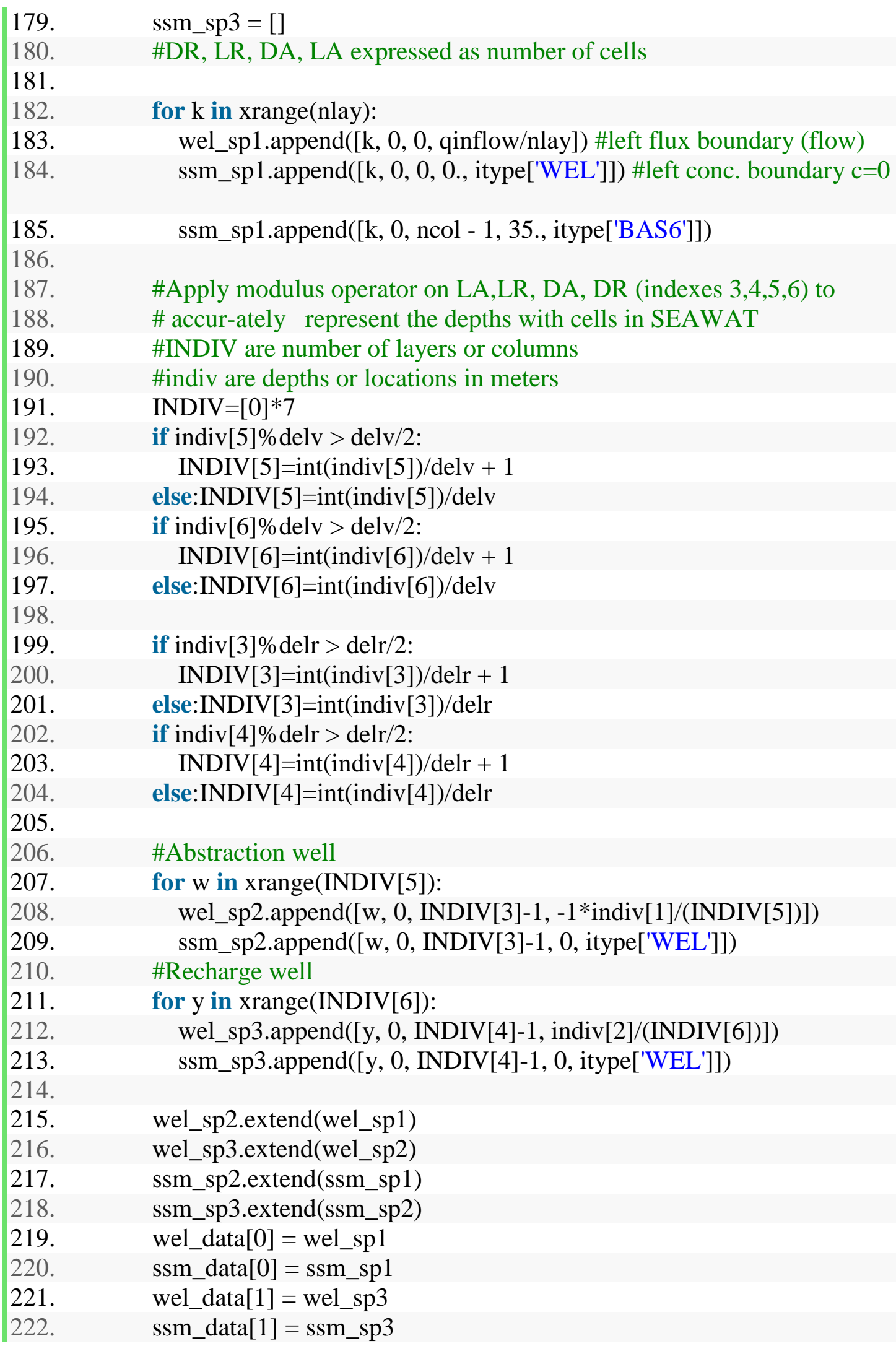




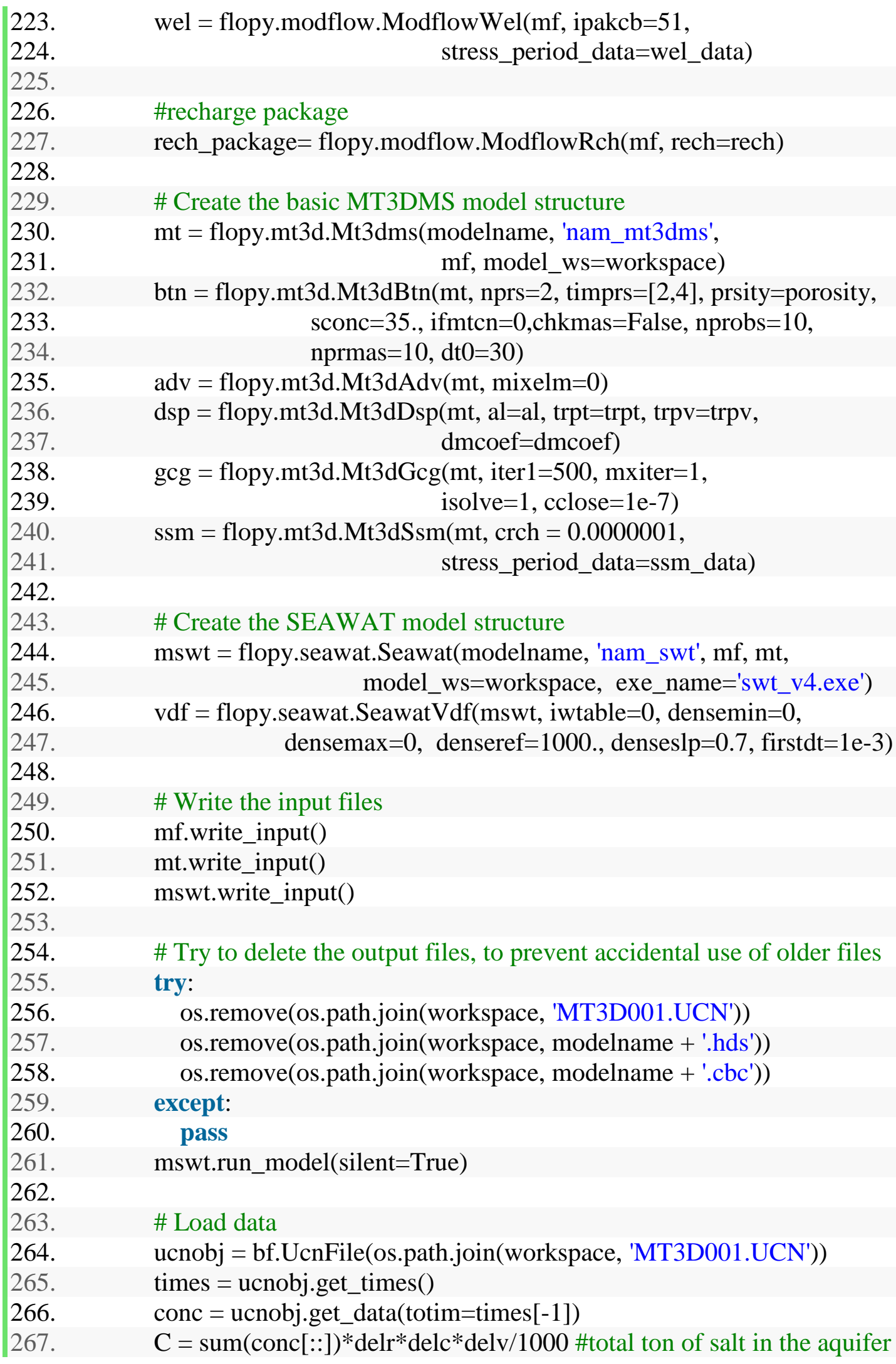




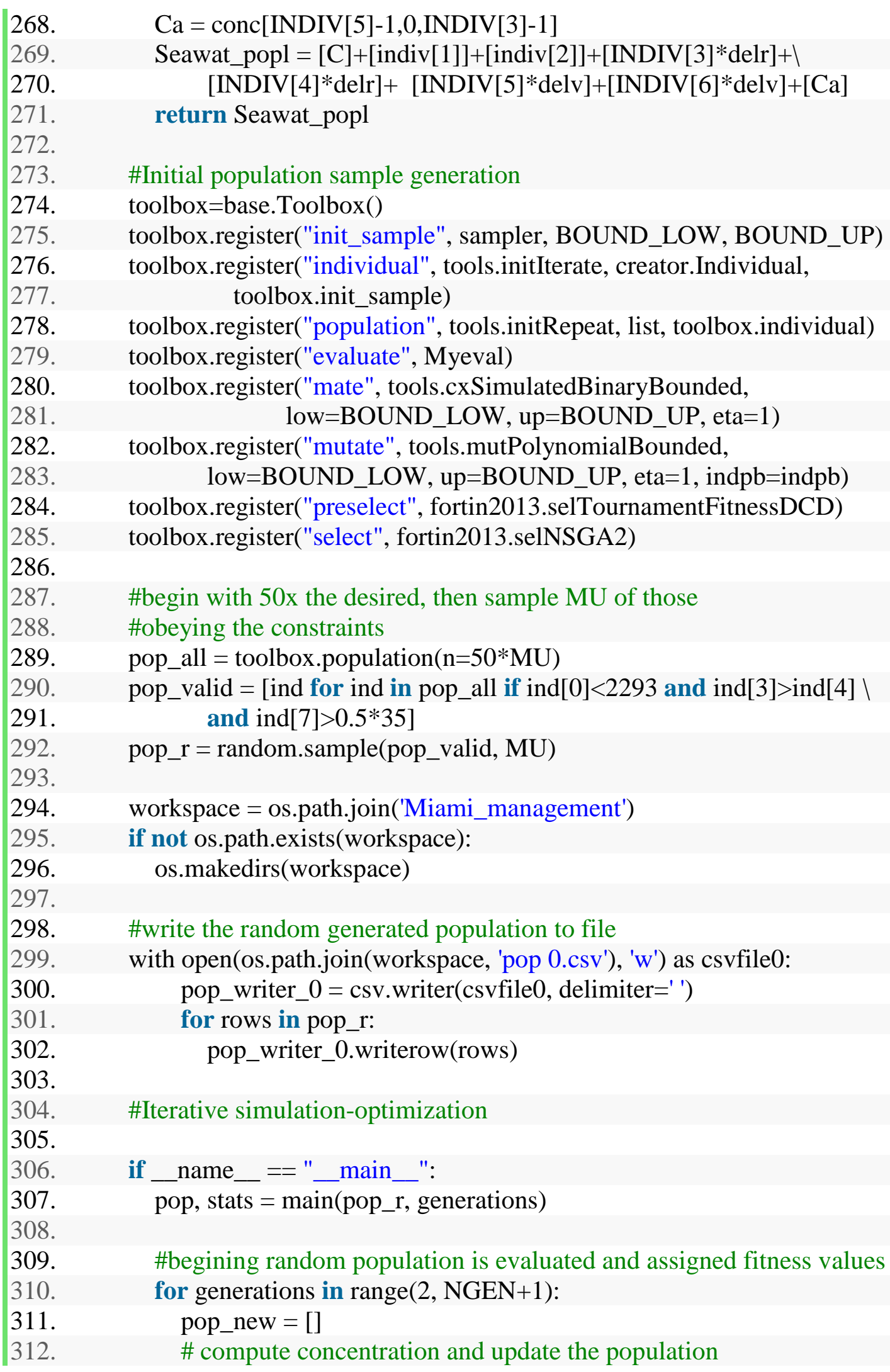


313.

314.

315.

316.

317.

318.

319.

320.

321.

322.

323.

324.

325.

326.

327.

328.

329.

330.

331.

332.

333.

334.

335.

336.

337.

338.

339.

340.

341.

342.

343.

344.

345.

346.

347.

348.

349.

350.

351.

352.

353.

354.

355.

356.

\#then assign individual attributes to indivs.

for indivs in pop:

pop_attr = creator.Individual(Seawat_simulation(indivs))

pop_new.append(pop_attr)

pop, stats = main(pop_new, generations)

\#plotting pareto fronts

pop.sort(key=lambda $x$ : $x$.fitness.values)

front $=$ np.array $([$ ind.fitness.values for ind in pop $])$

colors $=$ cm.rainbow $($ np.linspace $(0,1$, NGEN $))$

plt.scatter(front[:,0], front[:,1], c='b') \#colors[generations-2]

\#plt.legend('gen\%s'\%(generations))

plt.axis("tight")

plt.xlabel('\$f_1(ไmathbf $\{\mathrm{x}\}) \$$ ');plt.ylabel('\$f_2(lmathbf $\{\mathrm{x}\}) \$$ ');

plt.savefig(os.path.join(workspace, 'Gen \%s.png'\%(generations)))

plt.show()

\#saving populations to csv file

with open(os.path.join(workspace, 'pop \%s.csv'\%(generations)),

'w') as csvfile1:

pop_writer $=$ csv. writer $($ csvfile1, delimiter=' ' $)$

for row in pop:

pop_writer.writerow(row)

with open(os.path.join(workspace, 'front.csv'), 'w') as csvfile2:

front_writer $=$ csv.writer(csvfile2, delimiter=' ')

front_writer.writerows(front)

\#Color map and contour of concentration plots

ucnobj = bf.UcnFile(os.path.join(workspace, 'MT3D001.UCN'))

times $=$ ucnobj.get_times()

conc $=$ ucnobj.get_data(totim=times[-1])

cbbobj = bf.CellBudgetFile(os.path.join(workspace, modelname+'.cbc'))

times $=$ cbbobj.get_times()

qx = cbbobj.get_data(text='flow right face', totim=times[-1])[0]

$\mathrm{qz}=$ cbbobj.get_data(text='flow lower face', totim=times[-1])[0]

\#Average flows to cells, used to plot the velocity vectors

qx_avg = np.empty(qx.shape, dtype=qx.dtype)

qx_avg[:, :, 1:] $=0.5 *$ (qx[:, :, 0:ncol-1] + qx[:, :, 1:ncol] $)$

qx_avg[:, :, 0] $=0.5 *$ qx[:, :, 0$]$

qz_avg = np.empty(qz.shape, dtype=qz.dtype)

qz_avg[1:, :, :] $=0.5 *(\mathrm{qz}[0:$ nlay-1, :, :] + qz[1:nlay, :, :] $)$

qz_avg[0,:,:] $=0.5 *$ qz $[0,:,:]$ 


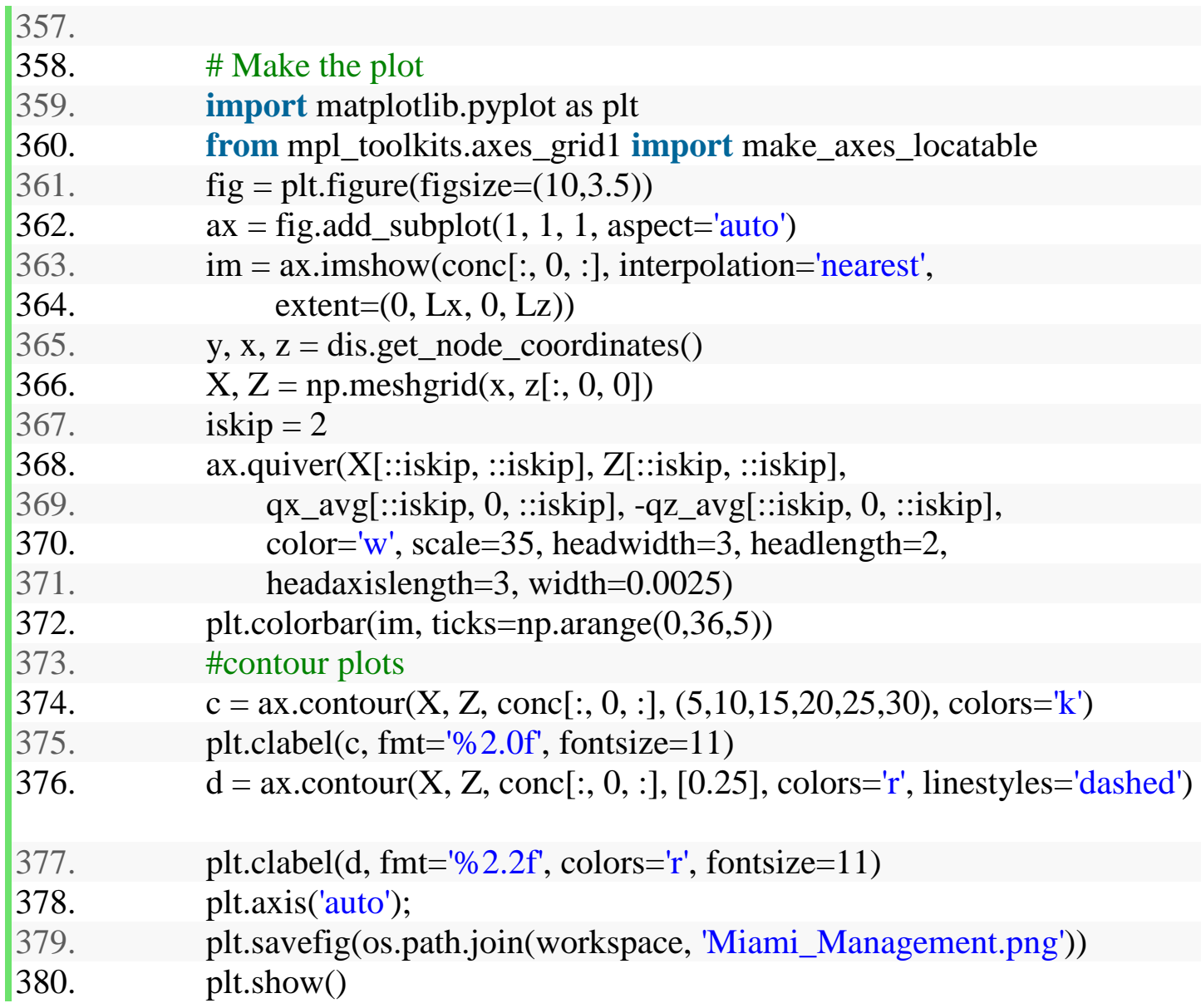


VITA

YONAS TEKLEAB HABTEMICHAEL

Born, Asmara, Eritrea

2007

B.Sc., Civil Engineering

University of Asmara

Asmara, Eritrea

2007-2010

Lecturer

Eritrea Institute of Technology

Mai-Nefhi, Eritrea

2011-2013

Presidential Fellowship Award Florida International University Miami, Florida

2013-2015

Graduate Teaching Assistant

Florida International University

Miami, Florida

2015

M.Sc., Civil Engineering

Florida International University

Miami, Florida

2013-2015

Doctoral Candidate

Florida International University

Miami, Florida

\section{PUBLICATIONS AND PRESENTATIONS}

Habtemichael, Y.T., Fuentes, H.R. (2016), Hydrogeochemical Analysis of Processes through Modeling of Seawater Intrusion Impacts in Biscayne Aquifer Water Quality, USA. Aquatic Geochemistry, doi: 10.1007/s10498-016-9287-1.

Habtemichael, Y.T., Fuentes, H.R. (2016). Influence of Groundwater Mixing on Uranium Speciation in Unconfined and Confined Carbonate Aquifer. Submitted to Environmental Engineering Science (21 pages).

Habtemichael, Y.T., Fuentes, H.R. (2016), Process-based reactive transport modeling of the Kissimmee River Aquifer Storage and Recovery, USA. In preparation.

Habtemichael, Y.T., Fuentes, H.R. (2016), Multi-objective optimization of saltwater management: case of Biscayne Aquifer, USA. In preparation. 
Habtemichael, Y.T., Fuentes, H.R. (August, 2015). Modeling Impact of Saline Intrusion on Freshwater of a Coastal Aquifer. Paper presented at the $24^{\text {th }}$ Annual CWWA Conference and Exposition, Miami, Florida.

Habtemichael, Y.T., Fuentes, H.R. (March, 2015). Dissolution and Precipitation Reactions Driven by Saltwater Intrusion in the Biscayne Aquifer, Miami-Dade County, Florida. Paper presented at the NGWA Groundwater Summit, San Antonio, Texas.

Habtemichael, Y.T., Kiflemariam, R.T., and Fuentes, H.R. (October, 2014). Evaluation of Instability of a Low-salinity Density-dependent Flow in a Porous Medium. Proceedings of COMSOL conference, Boston, Massachusetts.

Habtemichael, Y.T., Fuentes, H.R. (October, 2013). U(VI) Speciation at an Aquifer Storage and Recovery (ASR) site in the Floridan Aquifer System. Paper presented at the $14^{\text {th }}$ Water Information Summit, Miami, Florida.

Habtemichael, Y.T., Fuentes, H.R. (June, 2012). Geochemical Scenarios of Saline Intrusion Impacts on Biscayne Aquifer Water Quality and Adaptive Recharge. Paper presented at the Risk and Response: Sea Level Rise Summit, The future of Florida and the Coast, Boca Raton, Florida. 